\title{
Nutrient, Suspended Sediment, and Trace Element Loads in the Blackstone River Basin in Massachusetts and Rhode Island, 2007 to 2009
}

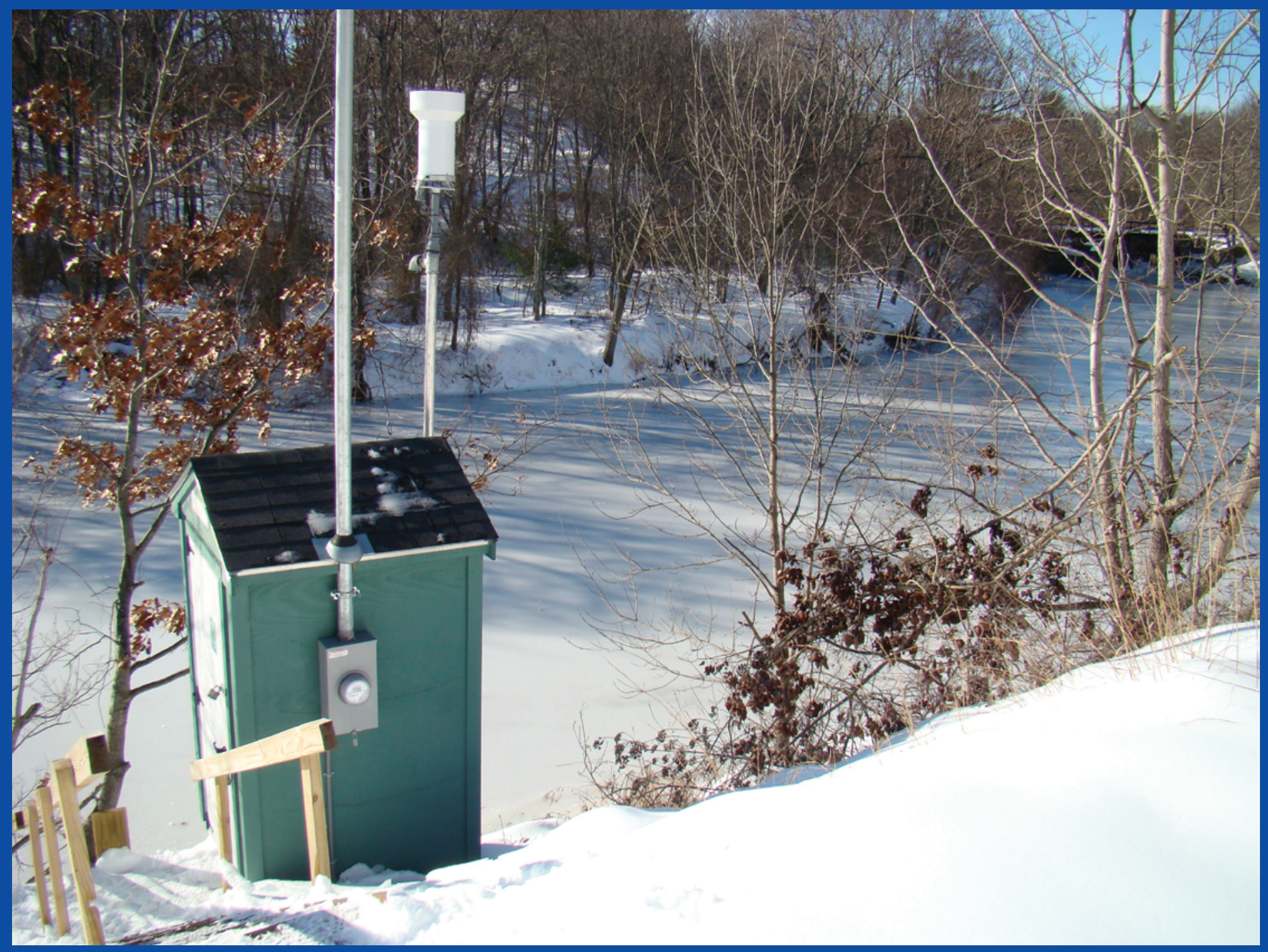

Scientific Investigations Report 2015-5026 
Cover. Monitoring station on the Blackstone River at Millville, Massachusetts, in winter 2007. Photograph by Andy Waite, U.S. Geological Survey. 


\section{Nutrient, Suspended Sediment, and Trace Element Loads in the Blackstone River Basin in Massachusetts and Rhode Island, 2007 to 2009}

By Marc J. Zimmerman, Marcus C. Waldron, and Leslie A. DeSimone

Prepared in cooperation with the

Massachusetts Department of Environmental Protection

Scientific Investigations Report 2015-5026 


\title{
U.S. Department of the Interior SALLY JEWELL, Secretary
}

\section{U.S. Geological Survey \\ Suzette M. Kimball, Acting Director}

\author{
U.S. Geological Survey, Reston, Virginia: 2015
}

For more information on the USGS - the Federal source for science about the Earth, its natural and living resources, natural hazards, and the environment-visit http://www.usgs.gov/ or call 1-888-ASK-USGS.

For an overview of USGS information products, including maps, imagery, and publications, visit http://www.usgs.gov/pubprod/.

Any use of trade, firm, or product names is for descriptive purposes only and does not imply endorsement by the U.S. Government.

Although this information product, for the most part, is in the public domain, it also may contain copyrighted materials as noted in the text. Permission to reproduce copyrighted items must be secured from the copyright owner.

Suggested citation:

Zimmerman, M.J., Waldron, M.C., and DeSimone, L.A., 2015, Nutrient, suspended sediment, and trace element loads in the Blackstone River Basin in Massachusetts and Rhode Island, 2007 to 2009: U.S. Geological Survey Scientific Investigations Report 2015-5026, 112 p., http://dx.doi.org/10.3133/sir20155026.

ISSN 2328-0328 (online) 


\section{Acknowledgments}

This report benefitted greatly from the support and assistance of our cooperators and U.S. Geological Survey colleagues. Dennis R. Dunn, Elaine Hartman, Kimberly Groff, Alice Rojko, and Bryant Firmin from the Massachusetts Department of Environmental Protection enthusiastically supported and helped guide the work. Many U.S. Geological Survey staff and scientists contributed to the completion of the study described in this report. Kirk Smith designed, assembled, and installed the water-quality sampling system. Robert Breault served as project chief during the development and monitoring phases of the study. Kim Campo, Mark Nimiroski, and Dominic Murino were responsible for performing most of the intensive fieldwork that the monitoring, sample processing, and equipment maintenance demanded. Lance Ostiguy produced maps and geographic information system-based information. Gina Daniels and Elizabeth Abate provided assistance with data management and the production of figures used in this report. Virginia L. McGuire and David L. Lorenz provided invaluable support for our applications of statistical software. 



\section{Contents}

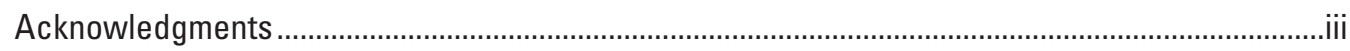

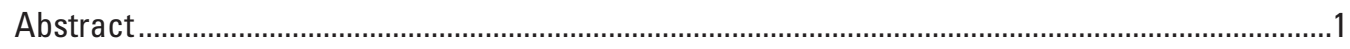

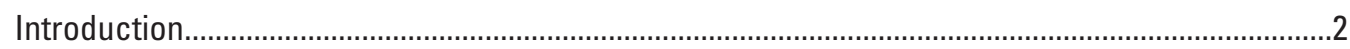

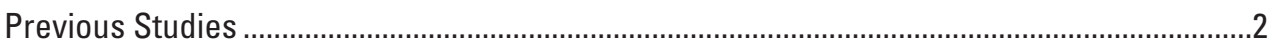

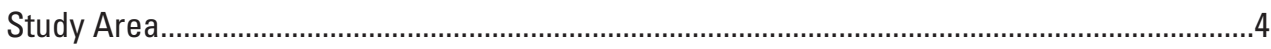

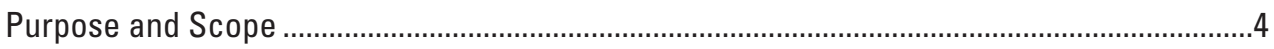

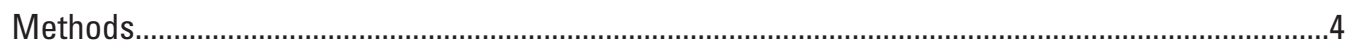

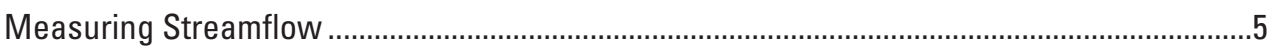

Automated, Flow-Proportional, Water-Quality Sampling .......................................................

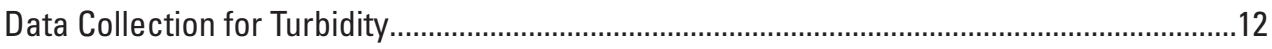

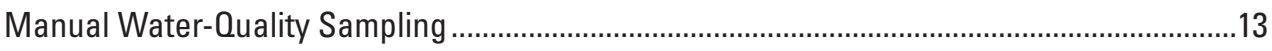

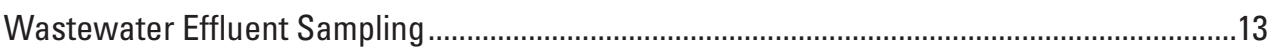

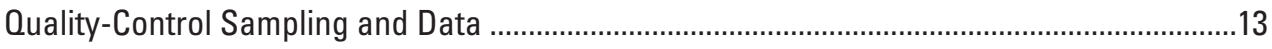

Blank and Replicate Quality-Control Samples ..............................................................13

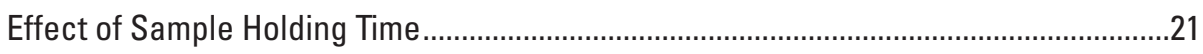

Concentration Data and Constituent Load Calculations ......................................................21

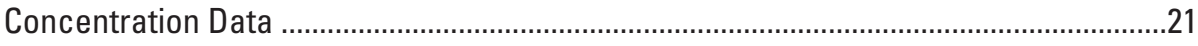

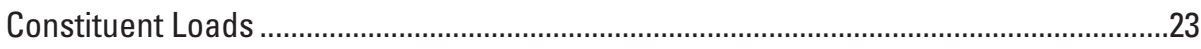

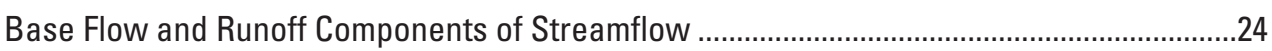

Constituent Loads in the Blackstone River Basin ..........................................................................24

Nitrogen, Phosphorus, and Suspended Sediment Loads in the Massachusetts

Segment of the Blackstone River Basin ....................................................................24

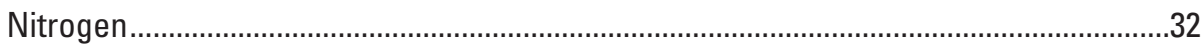

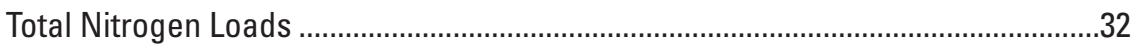

Nitrogen Loads and Hydrologic Conditions.........................................................32

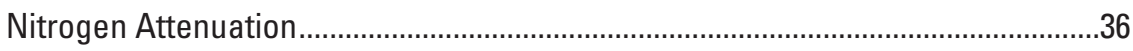

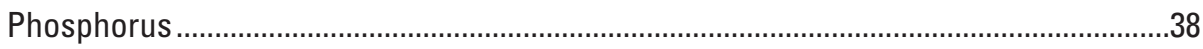

Suspended Sediment ............................................................................................39

Annual Loads of Nitrogen, Phosphorus, and Suspended Sediment at Millville, Massachusetts ................................................................................................39

Comparisons of Nutrient, Suspended Sediment, and Trace Element Loads at Millville,

Massachusetts, and Pawtucket, Rhode Island.........................................................40

Potential for Resuspension and Transport of Trace Element- and Nutrient-Enriched Bottom

Sediment From Two Blackstone River Impoundments ...................................................49

Turbidity Patterns in Relation to Streamflow and Precipitation.............................................52

Turbidity as a Surrogate for Particulate Trace Elements, Nutrients, and Suspended

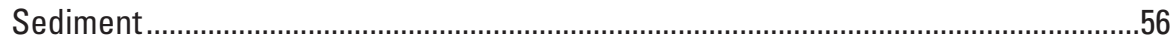

Effects of Sediment Resuspension on Contaminant Concentrations and Loads....................57

Changes in Trace Element Concentrations Resulting From Sediment Resuspension ...57

Changes in Constituent Loading Resulting From Sediment Resuspension......................57

Effects of Flow on Changes in Constituent Loads During Passage Through

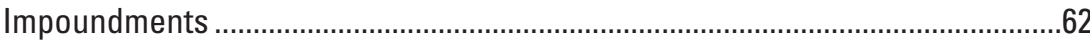

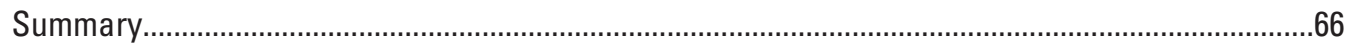

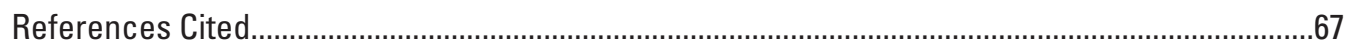


Appendix 1. Concentrations of Nitrogen and Phosphorus Analytes and Suspended Sediment in Composite Water-Quality Samples Collected at Monitoring Stations

in the Blackstone River, Massachusetts and Rhode Island, 2007 to 2009.

Appendix 2. Concentrations of Nitrogen and Phosphorus Analytes and Suspended Sediment in Equal-Width Increment and Point Water-Quality Samples Collected at Stream Monitoring Stations in the Blackstone River, Massachusetts and Rhode Island, 2007 to 2009

Appendix 3. Concentrations of Trace Elements in Composite Water-Quality Samples Collected at Stream Monitoring Stations in the Blackstone River Basin, Massachusetts and Rhode Island, 2007 to 2009

Appendix 4. Concentrations of Trace Elements in Equal-Width-Increment and Point WaterQuality Samples Collected at Stream Monitoring Stations in the Blackstone River Basin, Massachusetts and Rhode Island, 2007 to 2009

Appendix 5. Concentrations of Nitrogen and Phosphorus Analytes and Suspended Sediment in Composite Water-Quality Samples Collected at Wastewater Treatment Plants in the Blackstone River, Massachusetts and Rhode Island, 2007 to 2009 .83

Appendix 6. Constituent Loads and Streamflow at the Blackstone River Basin, Massachusetts and Rhode Island, 2007 to 2009. .85

\section{Figures}

1. Map showing the Blackstone River Basin in Massachusetts and Rhode Island

2. Schematic diagram of the Blackstone River Basin, Massachusetts and Rhode Island, major tributaries, and wastewater treatment plants .8

3. Photograph showing the automated sampling system used in the Blackstone River Basin, Massachusetts and Rhode Island.

4. Photographs showing water-quality- and streamflow-monitoring locations in the Blackstone River Basin in Massachusetts and Rhode Island 10

5. Graphs showing loads of total nitrogen, total phosphorus, and suspended sediment at stream monitoring stations and wastewater treatment plants from composite samples in the Blackstone River Basin, Massachusetts and Rhode Island, for the 2-week sampling periods starting A, August 28, 2007, B, April 28, 2008, C, June 24, 2008, D, September 16, 2008, E, May 13, 2009, F, July 7, 2009, and $G$, September 1, 2009...

6. Graphs showing comparison of total nitrogen loads and base-flow index at the stream monitoring station at the Blackstone River at Millville, Massachusetts (01111230), from 2007 to 2009, for $A$, total nitrogen load and $B$, total nitrogen load from wastewater treatment plants as percentage of total nitrogen load in the river.....36

7. Graphs showing loads of $A$, total nitrogen, $B$, total phosphorus, and $C$, suspended sediment and streamflow in the Blackstone River at monitoring stations in Millville, Massachusetts (01111230), and Pawtucket, Rhode Island (01113895), for September 1 to November 3, 2008, and May 1 to October 1, 2009.

8. Graphs showing loads of $A$, total cadmium, $B$, total chromium, $C$, total copper, $D$, total lead, $E$, total nickel, and $F$, total zinc and streamflow in the Blackstone River at monitoring stations at Millville, Massachusetts (01111230), and Pawtucket, Rhode Island (01113895), from September 1 to November 3, 2008 .44

9. Satellite images of the $A$, former Rockdale Pond impoundment and $B$, Rice City Pond impoundment on the Blackstone River, Massachusetts ..... 
10. Graphs showing turbidity patterns at Blackstone River monitoring stations upstream (01110400) and downstream (01110500) from the former Rockdale Pond impoundment on the Blackstone River, Massachusetts, during water year 2008, in relation to measured streamflow at the monitoring station and to precipitation at the Upper Blackstone Water Pollution Control Abatement District wastewater treatment plant in Millbury, Mass.

11. Graphs showing turbidity patterns at Blackstone River monitoring stations upstream (01110530) and downstream (01110535) from the Rice City Pond impoundment on the Blackstone River, Massachusetts, during water year 2008, in relation to measured streamflow at the monitoring station and to precipitation at the Upper Blackstone Water Pollution Control Abatement District wastewater treatment plant in Millbury, Mass..

12. Graphs showing turbidity patterns at four Blackstone River monitoring stations upstream and downstream from the former Rockdale Pond and Rice City Pond impoundment on the Blackstone River, Massachusetts, in relation to measured streamflow at during the $A$, December 22 to 28,2007 , and $B$, March 15 to April 4, 2008, storms.

13. Graphs showing the effects of sediment resuspension on estimated particulate trace element concentrations at streamflow and water-quality monitoring stations $A$, upstream (station 01110400) and $B$, downstream (station 01110500) from the former Rockdale Pond impoundment on the Blackstone River, Massachusetts, during selected high-flow events in water year 2008.

14. Graphs showing the effects of sediment resuspension on estimated particulate trace element concentrations at streamflow and water-quality monitoring stations $A$, upstream (station 01110530) and $B$, downstream (station 01110535) from the Rice City Pond impoundment on the Blackstone River, Massachusetts, impoundment during selected high-flow events in water year 2008.

15. Graphs showing the effects of sediment resuspension on particulate chromium loads at four Blackstone River monitoring stations upstream and downstream from the former Rockdale Pond and Rice City Pond impoundments on the Blackstone River, Massachusetts, for $A$, December 19 to 31, 2007, and $B$, March 16 to April 2, 2008.

16. Graphs showing the effects of sediment resuspension on particulate phosphorus loads at four Blackstone River monitoring stations upstream and downstream from the former Rockdale Pond and Rice City Pond impoundments on the Blackstone River, Massachusetts, for $A$, December 19 to 31, 2007, and B, March 16 to April 4, 2008.

17. Graphs showing the effects of sediment resuspension on suspended sediment loads at four Blackstone River monitoring stations upstream and downstream from the former Rockdale Pond and Rice City Pond impoundments on the Blackstone River, Massachusetts, for $A$, December 19, 2007, to January 1, 2008, and $B$, March 16 to April 4, 2008 .

18. Graphs showing the effects of streamflow on changes in maximum daily particulate chromium loads in the $A$, former Rockdale Pond and $B$, Rice City Pond impoundments on the Blackstone River, Massachusetts, during high-flow events in water year 2008..

19. Graphs showing the effects of streamflow on changes in maximum daily particulate phosphorus loads in the $A$, former Rockdale Pond and $B$, Rice City Pond impoundments on the Blackstone River, Massachusetts, during high-flow events in water year 2008. 
20. Graphs showing the effects of streamflow on changes in maximum daily suspended sediment loads in the $A$, former Rockdale Pond and $B$, Rice City Pond impoundments on the Blackstone River, Massachusetts, during high-flow events in water year 2008

\section{Tables}

1. Monitoring stations in the Blackstone River Basin, Massachusetts and Rhode Island, and data-collection information

2. Water-quality constituents in quality-assurance blank and replicate samples and relative percent differences between environmental-sample concentrations (composites) and replicate samples for the Blackstone River Basin in Massachusetts and Rhode Island...

3. Loads of total nitrogen, total phosphorus, and suspended sediment at stream monitoring stations and wastewater treatment plants from 2-week composite samples in the Blackstone River Basin, Massachusetts and Rhode Island, from 2007 to 2009

4. Estimated loads of total nitrogen, total phosphorus, and suspended sediment at stream monitoring stations and wastewater treatment plants from 2-week composite samples in the Blackstone River Basin, Massachusetts and Rhode Island, from 2007 to 2009

5. Estimated net change in total nitrogen loads along reaches of the main stem Blackstone River between Millbury, Massachusetts and Pawtucket, Rhode Island, from 2007 to 2009 .

6. Estimated total annual loads of nutrients, suspended sediment, and selected trace elements in the Blackstone River at Millville, Massachusetts, in water years 2008 and 2009

7. Loads of selected trace elements from 2-week composite samples collected at monitoring stations in the Blackstone River at Millville, Massachusetts, and Pawtucket, Rhode Island, in 2007 and 2008.

8. Variables of linear regression equations for constituent loads and measured turbidity for four streamflow and water-quality-monitoring stations on the Blackstone River, Massachusetts, during water year 2008 


\section{Conversion Factors}

Inch/Pound to International System of Units

\begin{tabular}{|c|c|c|}
\hline Multiply & By & To obtain \\
\hline \multicolumn{3}{|c|}{ Length } \\
\hline inch (in.) & 2.54 & centimeter $(\mathrm{cm})$ \\
\hline inch (in.) & 25.4 & millimeter (mm) \\
\hline foot $(\mathrm{ft})$ & 0.3048 & meter (m) \\
\hline mile (mi) & 1.609 & kilometer (km) \\
\hline \multicolumn{3}{|c|}{ Area } \\
\hline square mile $\left(\mathrm{mi}^{2}\right)$ & 259.0 & hectare (ha) \\
\hline square mile $\left(\mathrm{mi}^{2}\right)$ & 2.590 & square kilometer $\left(\mathrm{km}^{2}\right)$ \\
\hline \multicolumn{3}{|c|}{ Volume } \\
\hline gallon (gal) & 3.785 & liter $(\mathrm{L})$ \\
\hline gallon (gal) & 0.003785 & cubic meter $\left(\mathrm{m}^{3}\right)$ \\
\hline gallon (gal) & 3.785 & cubic decimeter $\left(\mathrm{dm}^{3}\right)$ \\
\hline million gallons (Mgal) & 3,785 & cubic meter $\left(\mathrm{m}^{3}\right)$ \\
\hline cubic foot $\left(\mathrm{ft}^{3}\right)$ & 28.32 & cubic decimeter $\left(\mathrm{dm}^{3}\right)$ \\
\hline cubic foot $\left(\mathrm{ft}^{3}\right)$ & 0.02832 & cubic meter $\left(\mathrm{m}^{3}\right)$ \\
\hline \multicolumn{3}{|c|}{ Flow rate } \\
\hline foot per second (ft/s) & 0.3048 & meter per second $(\mathrm{m} / \mathrm{s})$ \\
\hline cubic foot per second $\left(\mathrm{ft}^{3} / \mathrm{s}\right)$ & 0.02832 & cubic meter per second $\left(\mathrm{m}^{3} / \mathrm{s}\right)$ \\
\hline \multicolumn{3}{|c|}{ Mass } \\
\hline ounce, avoirdupois (oz) & 28.35 & gram $(\mathrm{g})$ \\
\hline pound, avoirdupois (lb) & 0.4536 & kilogram (kg) \\
\hline
\end{tabular}

Temperature in degrees Celsius $\left({ }^{\circ} \mathrm{C}\right)$ may be converted to degrees Fahrenheit $\left({ }^{\circ} \mathrm{F}\right)$ as ${ }^{\circ} \mathrm{F}=\left(1.8 \times{ }^{\circ} \mathrm{C}\right)+32$.

Temperature in degrees Fahrenheit $\left({ }^{\circ} \mathrm{F}\right)$ may be converted to degrees Celsius $\left({ }^{\circ} \mathrm{C}\right)$ as ${ }^{\circ} \mathrm{C}=\left({ }^{\circ} \mathrm{F}-32\right) / 1.8$.

\section{Datum}

Vertical coordinate information is referenced to the North American Vertical Datum of 1988 (NAVD 88).

Horizontal coordinate information is referenced to the North American Datum of 1983 (NAD 83). 


\section{Abbreviations}

$\begin{array}{ll}\text { BFI } & \text { base-flow index } \\ \text { EWI } & \begin{array}{l}\text { equal-width increment } \\ \text { formazin nephelometric unit }\end{array} \\ \text { FNU } & \text { Massachusetts Department of Environmental Protection } \\ \text { NWOL } & \text { National Water Quality Laboratory } \\ R^{2} & \text { coefficient of determination } \\ \text { UBWPAD } & \text { Upper Blackstone Water Pollution Abatement District } \\ \text { USGS } & \text { U.S. Geological Survey }\end{array}$




\title{
Nutrient, Suspended Sediment, and Trace Element Loads in the Blackstone River Basin in Massachusetts and Rhode Island, 2007 to 2009
}

\author{
By Marc J. Zimmerman, Marcus C. Waldron, and Leslie A. DeSimone
}

\section{Abstract}

Nutrients, suspended sediment, and trace element loads in the Blackstone River and selected tributaries were estimated from composite water-quality samples in order to better understand the distribution and sources of these constituents in the river basin. The flow-proportional composite waterquality samples were collected during sequential 2-week periods at six stations along the river's main stem, at three stations on tributaries, and at four wastewater treatment plants in the Massachusetts segment of the basin from June 2007 to September 2009. Samples were collected at an additional station on the Blackstone River near the mouth in Pawtucket, Rhode Island, from September 2008 to September 2009. The flow-proportional composite samples were used to estimate average daily loads during the sampling periods; annual loads for water years 2008 and 2009 also were estimated for the monitoring station on the Blackstone River near the Massachusetts-Rhode Island border. The effects of hydrologic conditions and net attenuation of nitrogen were investigated for loads in the Massachusetts segment of the basin. Sediment resuspension and contaminant loading dynamics were evaluated in two Blackstone River impoundments, the former Rockdale Pond (a breached impoundment) and Rice City Pond.

Total nitrogen and phosphorus loads along the Blackstone River in Massachusetts showed similar general patterns during the sampling periods monitored in this study. Total nitrogen loads were relatively low at the farthest upstream monitoring station in Millbury, Massachusetts (typically less than 430 kilograms per day $(\mathrm{kg} / \mathrm{d})$ for total nitrogen and $37 \mathrm{~kg} / \mathrm{d}$ for total phosphorus). Loads typically increased (5- to 10-fold for nitrogen and 6- to 15-fold for phosphorus) downstream from the first, large wastewater treatment plant along the river, the Upper Blackstone Water Pollution Control Abatement District in Millbury. Further downstream, total nitrogen and phosphorus loads remained elevated but variable (typically about 1,000 to $3,000 \mathrm{~kg} / \mathrm{d}$ for nitrogen and about 100 to $370 \mathrm{~kg} / \mathrm{d}$ for phosphorus) from Millbury to the Massachusetts-Rhode Island border near Millville, Mass. Monitored tributaries of the Blackstone River and wastewater treatment plants other than the Upper Blackstone Water Pollution Control Abatement District rarely contributed more than a small fraction of the total nitrogen and phosphorus loads observed at the main stem monitoring stations. Loads of suspended sediment also were substantially larger along the river's main stem than in tributaries during most sampling periods. Very large loads of suspended sediment from the West River tributary during several sampling periods may have been associated with flood-control operations.

The estimated annual load of total nitrogen in the Blackstone River at Millville, about 1.3 miles upstream from the Massachusetts-Rhode Island border, was 936,000 kilograms $(\mathrm{kg})(2,600 \mathrm{~kg} / \mathrm{d})$ in water year 2008 and $878,000 \mathrm{~kg}(2,400 \mathrm{~kg} / \mathrm{d})$ in water year 2009 . The estimated annual load of total phosphorus at Millville was $81,400 \mathrm{~kg}$ in water year $2008(223 \mathrm{~kg} / \mathrm{d})$ and 80,900 kg (222 kg/d) in water year 2009. The estimated annual load of suspended sediment in was 4,940,000 kg $(13,600 \mathrm{~kg} / \mathrm{d})$ in water year 2008 and $7,040,000 \mathrm{~kg}(19,300 \mathrm{~kg} / \mathrm{d})$ in water year 2009 . The higher load in water year 2009 likely reflects several large storms in summer 2009, which resulted in streamflows in the Blackstone River that were 10 times the typical July flows. Loads of total nitrogen, total phosphorus, and trace elements were almost always lower in the Blackstone River at Millville than in the river near its mouth at the Pawtucket monitoring station, when loads were monitored at both stations in the latter part of water year 2008 and in water year 2009. Loads of suspended sediment at Millville and Pawtucket varied by about the same range, but were usually lower at Pawtucket than at Millville.

Total nitrogen loads were higher during sampling periods when the base-flow contribution to streamflow was substantially less than the runoff contribution than in sampling periods when the base-flow dominated. During these sampling periods when the runoff component of streamflow was relatively large, loads of total nitrogen in wastewater discharge from Upper Blackstone Water Pollution Control Abatement District also were high but also constituted smaller fractions of the total nitrogen loads in the river. Nitrogen attenuation may have occurred during some sampling periods, based on net changes in total nitrogen load between consecutive monitoring stations, especially in the Blackstone River reach between the South Grafton and Uxbridge monitoring stations. 
Analysis of the representative constituents (total phosphorus, total chromium, and suspended sediment) upstream and downstream of impoundments indicated that the existing impoundments, such as Rice City Pond, can be sources of particulate contaminant loads in the Blackstone River. Loads of particulate phosphorus, particulate chromium, and suspended sediment were consistently higher downstream from Rice City Pond than upstream during high-flow events, and there was a positive, linear relation between streamflow and changes in these constituents from upstream to downstream of the impoundment. Thus, particulate contaminants were mobilized from Rice City Pond during high-flow events and transported downstream. In contrast, downstream loads of particulate phosphorus, particulate chromium, and suspended sediment were generally lower than or equal to upstream loads for the former Rockdale Pond impoundment. Sediments associated with the former impoundment at Rockdale Pond, breached in the late 1960s, did not appear to be mobilized during the highflow events monitored during this study.

\section{Introduction}

The Blackstone River Basin in central Massachusetts and Rhode Island comprises an area of 475 square miles $\left(\mathrm{mi}^{2}\right)$ and includes one of New England's largest cities, Worcester, Massachusetts (fig. 1). From its origin near Worcester, the river flows 48 miles (mi) through Woonsocket and Pawtucket, Rhode Island, before discharging into Narragansett Bay. The river basin has a long history of contamination, dating back to the industrial revolution. Improved infrastructure and wastewater treatment have resulted in improved water quality, but the river's water quality is still categorized as impaired along its entire length (Massachusetts Department of Environmental Protection, 2010; Massachusetts Executive Office of Energy and Environmental Affairs, 2015).

English settlers colonized the Blackstone River Valley in the 17th century (Kerr, 1990). The landscape and hydrology of the river basin were conducive hydropower development and, as a consequence, to industrialization; cotton mills came first, followed by factories that processed cotton cloth and that built supporting machinery or that just needed readily accessible hydropower. In addition to providing the power that mills and other factories required, the river also served as an open sewer for the wastes that were created by industry and the burgeoning population. The disposal of cotton dyes, industrial wastes, and sewage in the river left behind contaminated sediments containing toxic organic chemicals and metals.

Improvements to infrastructure and to wastewater treatment, especially after the passage of the Clean Water Act (33 U.S.C. $\$ 1251$ et seq.) in 1972, have reduced point- and nonpoint-source contaminant loadings that are eventually transported by the river to Narragansett Bay (Rhode Island Department of Environmental Management, 1998). Loads are currently being reduced through wastewater treatment plant upgrades, but reductions in contaminant loadings are still needed to achieve water-quality goals (U.S. Environmental Protection Agency, 2007; Upper Blackstone Water Pollution Abatement District, 2012, 2013; Massachusetts Executive Office of Energy and Environmental Affairs, 2015). Nutrients may contribute to eutrophication in the Blackstone River and Narragansett Bay, and trace elements may have toxic effects on aquatic organisms in the Blackstone River. In order to better focus reduction efforts, more detailed information is needed about loadings to the Blackstone River and its major tributaries. To address this need, the Massachusetts Department of Environmental Protection (MassDEP) and the U.S. Geological Survey (USGS) initiated a cooperative study of nutrient, suspended sediment, and trace element loads in the Blackstone River in 2006.

The overall objectives of the study were to (1) determine the magnitude and spatial and temporal patterns of nutrient, suspended sediment, and trace element loads in the Massachusetts and Rhode Island segments of the Blackstone River and (2) quantify the transport of nutrients and trace elements from Massachusetts to Rhode Island and to Narragansett Bay. Within the context of those objectives, expanded investigations were undertaken to evaluate nitrogen-attenuation throughout the Blackstone River Basin and to assess resuspension and transport of nutrients, suspended sediment, and trace elements from two main stem impoundments.

\section{Previous Studies}

Numerous studies of historical contamination in the Blackstone River have been undertaken. McGinn (1981) outlined plans for dredging sediments and testing samples for toxic trace elements and organic compounds. Izbicki (1993) described the results of a 3-year study of the Blackstone's stratified-drift aquifers, surface-water and groundwater quality, and the effect of induced infiltration from the river on the quality of well-water supplies. Surface-water-quality data were tabulated by Izbicki (1993) but not discussed in detail.

Wright and others (2001) reported the results of detailed investigations of water quality during the summer, dry-season, low-flow months of July and August 1991. The study included results of monitoring the chemistry and toxicity of discharges to the river, river-water and sediment quality, and an evaluation of the biological communities. Surface-water chemistry was found to have minimal toxic effects on test organisms, but the sediments showed substantial toxic effects. Excessive nutrients and trace elements were identified as primary causes of poor water quality in the Blackstone River and Narragansett Bay; the Upper Blackstone Water Pollution Abatement District (UBWPAD), a wastewater treatment plant, was found to be the largest source of nitrate, regardless of flow conditions, and the largest source of phosphorus under dry-weather conditions. Wet-weather runoff generally coincided with the largest loads of contaminants. The urban center of Worcester, in the river's 


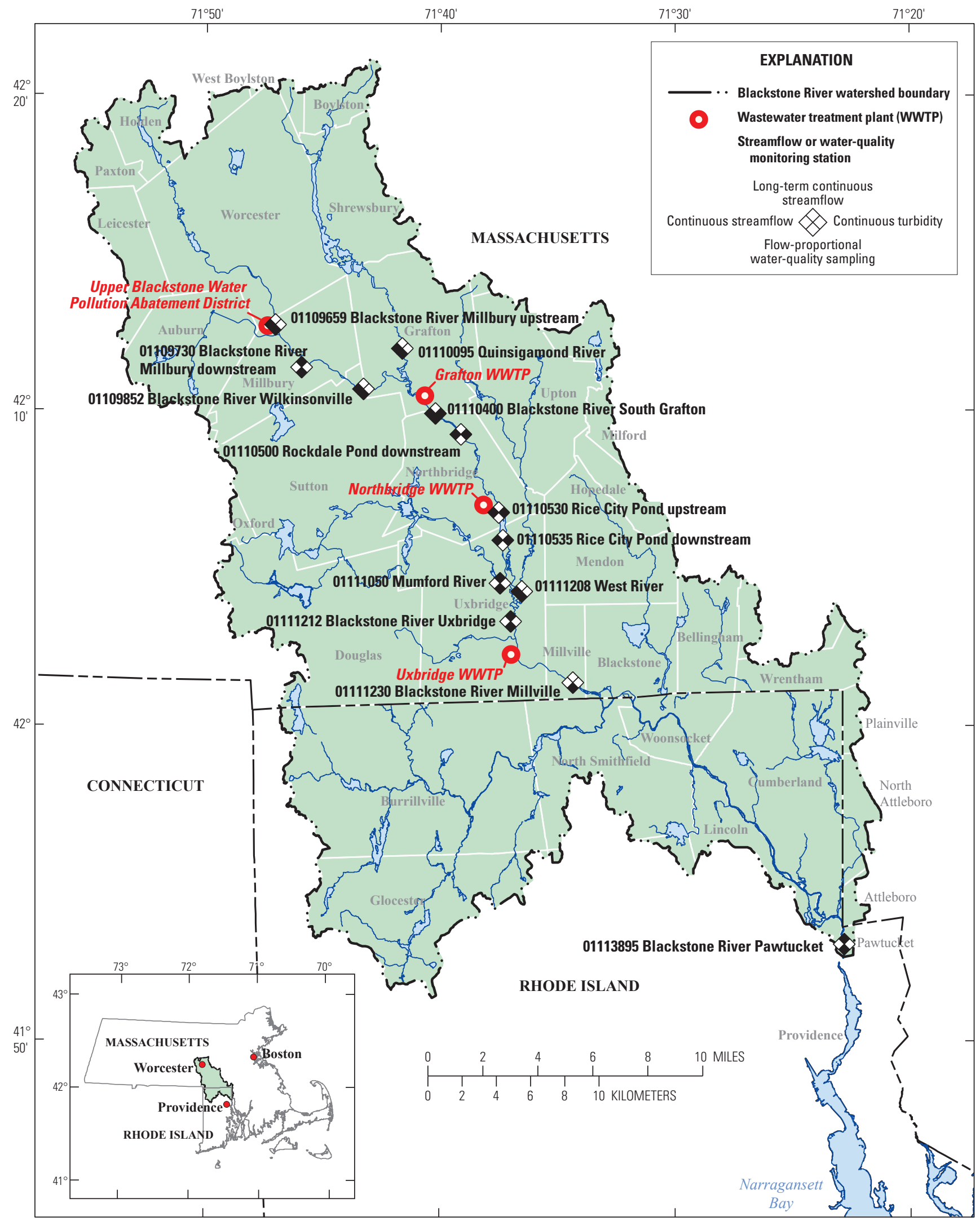

Base from U.S. Geological Survey and Massachusetts Office of Geographic Information digital data, 2014 Massachusetts State Plane Coordinate System, mainland zone

Figure 1. The Blackstone River Basin in Massachusetts and Rhode Island. 
Nutrient, Suspended Sediment, and Trace Element Loads in the Blackstone River Basin in Mass. and R.l., 2007 to 2009

headwaters, contributed substantially to loads of trace element contaminants in stormwater runoff.

The MassDEP has evaluated the status of water-quality conditions in the Blackstone River watershed with respect to designated uses (Massachusetts Department of Environmental Protection, 2010). The report by MassDEP consists of an extensive, but not all-inclusive, list of water bodies in the watershed and observations of water-quality conditions, based on sampling conducted primarily in 2003. The University of Massachusetts initiated a study of water quality in the Blackstone River in 2004, which included water-quality modeling for the period 1996 through 2008 (Upper Blackstone Water Pollution Abatement District, 2012, 2013; Water Resources Research Center, 2015, and references therein).

In 2009, Parker and others (2011) performed a time-oftravel study to determine how long it takes for water to travel $45 \mathrm{mi}$ from near the river's headwaters in Worcester to the mouth at the head of tide in Pawtucket. Under low to moderate streamflow of about 200 cubic feet per second $\left(\mathrm{ft}^{3} / \mathrm{s}\right)$, the travel time from Worcester (near the town boundary with Millbury) to the head of tide in Pawtucket was slightly less than 1 week (about 163 hours); the travel time from Worcester to the Massachusetts-Rhode Island State boundary (Millville station) was about 3 days.

\section{Study Area}

To take into consideration the major sources and transport of nutrients, suspended sediment, and trace elements in the Massachusetts segment of the Blackstone River, the main study area extended from a location immediately upstream from the UBWPAD to Millville close to the border with Rhode Island (fig. 1). Water-quality samples were collected at nine monitoring stations along the river's main stem in Massachusetts (table 1). Water-quality measurements from three tributaries, the West, Mumford, and Quinsigamond Rivers, draining $127 \mathrm{mi}^{2}$, also were included in the study, as were data from wastewater treatment plants in Millbury, Grafton, Northbridge, and Uxbridge, Mass. From September 2008 through September 2009, with the addition of a monitoring station on the Blackstone River at Pawtucket, the study area was expanded to include the river segment between Millville and Pawtucket. Inclusion of tributaries to the Blackstone River in Rhode Island was beyond the scope this study.

\section{Purpose and Scope}

This report describes loads of nutrients, suspended sediment, and trace elements in the Blackstone River between May 2007 and September 2009. Loads of total and dissolved nutrients, suspended sediment, and selected trace elements (cadmium, chromium, copper, lead, nickel, and zinc) at the boundary between Massachusetts and Rhode Island (Blackstone River Millville station) are described for the complete 2008 and 2009 water years. ${ }^{1}$ Loads of total nitrogen, total phosphorus, suspended sediment, and the same trace elements at Pawtucket, R.I., are described for parts of 2008 and 2009. Within the Massachusetts segment of the basin, upstream of the State boundary, loads of total and dissolved nutrients and suspended sediment are described for parts of water years 2008 and 2009 at monitoring stations along the Blackstone River and along its tributaries. Loads at Massachusetts stations upstream of the State boundary are based on about 262 -week composite samples collected during spring, summer and early fall seasons (late March through September); loads at the Millville station are based on 57 2-week composite samples collected year round; loads at the Pawtucket station are based on 14 2-week composite samples. The effects of hydrologic conditions and net attenuation of nitrogen loads are also described for loads in the Massachusetts segment of the basin. Finally, the report describes a detailed investigation of the potential for resuspension and transport of constituent loads from impoundments on the river, using Rice City Pond and the former Rockdale Pond as study areas.

\section{Methods}

An automated sampling system, designed and built by the USGS, collected nutrient, suspended sediment, and trace element samples for use in estimating loads entering and leaving the Massachusetts segment of the Blackstone River. Flow-proportional, water-quality samples of total and dissolved constituents were collected and composited during approximately 2-week periods at multiple locations along the Blackstone River and some of its tributaries (fig. 2; table 1) to improve understanding of temporal and spatial loading patterns. Because of highly variable chemical-constituent concentrations associated with treatment-plant operations and stormwater runoff, these sampling approaches were particularly important for estimating loads in the Blackstone River basin.

Wooden or metal shelters housed instrumentation (fig. 3) to monitor river stage and to collect samples. The shelters contained digital data loggers with data-storage modules that recorded and stored all generated data, automated sampling devices for collecting water samples, and telephone-modem systems to allow near-real-time reporting of provisional stage, discharge, and times of sample collection to the Northborough, Mass., office of the USGS New England Water Science Center. Sealed, rechargeable, 26-ampere-hour batteries powered the instrumentation. Municipal power supplies or solar power maintained battery charges.

\footnotetext{
${ }^{1} \mathrm{~A}$ water year is a continuous period from October 1 through September 30 and is designated by the year in which it ends.
} 


\section{Measuring Streamflow}

During the study period, streamflow was measured at 12 locations in Massachusetts and 1 in Rhode Island (figs. 1 and 2; table 1) by measuring river stage every 15 minutes by means of a pressure transducer connected to a data logger. Stage measurements were used to compute streamflow by means of stage-to-discharge relations (or ratings) that were developed with periodic manual measurements of stage and discharge every 6 to 8 weeks made either by wading or by acoustic Doppler technology (Rantz and others, 1982; Kennedy, 1984; Turnipseed and Sauer, 2010).

At the Blackstone River Millville monitoring station (01111230), low stream velocities prevented accurate measurements of streamflow using standard USGS streamflow measuring protocols (Rantz and others, 1982). For this reason, streamflow was not measured at this station but was estimated using streamflow data from the Blackstone River Rt. 122 Uxbridge monitoring station (01111212), about $3.5 \mathrm{mi}$ upstream and the drainage-area ratio method; to trigger sampling, a telephone-modem system communicated information between the two stations.

\section{Automated, Flow-Proportional, Water-Quality Sampling}

Flow-proportional, water-quality samples for chemical analysis were collected at 10 monitoring stations, using either automated sampling devices designed and built by the USGS for this study (fig. 3) or commercially available, automatic samplers (Teledyne Isco model 6700). Flowproportional samples are composited from subsamples collected at frequencies that are proportional to streamflow; more subsamples are collected during periods of high flow and fewer are collected during periods of low flow to yield a composite sample that is representative of the total volume of water flowing past the sampling station during the time period of sampling. For the most part, samples were collected and composited over approximately 2 -week periods. Sample collection took place in spring, summer, and early fall (late March through September) at 9 of the 10 monitoring stations where flow-proportional composite sampling was conducted (fig. 4; table 1), and year-round at Millville, near the Massachusetts-Rhode Island border. From the project's start in May 2007 through late May 2008, sample collection at the nine part-year monitoring stations took place for 2-week periods followed by 2-week periods when there was no sample collection. Starting in late May 2008, 2-week sampling periods in spring, summer, and early fall were continuous, without being broken by intervening periods when there was no sampling. Samples generally were not collected from October through February at the part-year monitoring stations. Sample collection at Millville was, by design, essentially continuous, interrupted only by problems related to logistics. Overall during the study, about 262 -week composite samples were collected at most main stem and tributary monitoring stations; 57 and 14 2-week composite samples were collected at the Millville (01111230) and Pawtucket (01113895) stations, respectively, on the main stem Blackstone River.

Total and dissolved nutrient, suspended sediment, and trace element loads to the Blackstone River were monitored from May 2007 through September 2009, but not all constituents were measured at all stations at all times (table 1; appendixes 1 and 2). Nutrients and suspended sediments were measured at all monitoring stations during the study period. Trace elements were measured at Millville, near the Massachusetts-Rhode Island border, and at Pawtucket near the river's outlet to Narragansett Bay to compare loads entering and leaving Rhode Island. Trace elements were measured at four additional stations located upstream and downstream of two impoundments in Massachusetts to evaluate the potential for resuspension and transport of trace elements under different streamflow conditions (appendixes 3 and 4). Nutrient, suspended sediment, and trace element samples were collected at the Pawtucket (01113895) station in September and October 2008 and May through September 2009.

Water-quality samples were collected by means of automated sampling equipment at time increments determined by the volume of water that passed by the station (trigger volume), which was calculated from measurements of stage using a stage-to-discharge relation. Water samples were collected incrementally during the 2-week period and composited automatically into large sample-collection bottles in the field. To estimate trigger volumes for each 2-week period, the likely effects of runoff on streamflow were predicted using local weather forecasts and real-time streamflow information. The targeted sampling rate was five samples per day. The trigger volume varied throughout the year with the seasonal variations in streamflow and base flow. The equipment was designed to collect and composite separate sets of nutrient and trace element samples for base-flow and storm-flow conditions, which were operationally defined as times of little to no change in stage and times of rapidly changing stage, respectively. However, taking into account flow regulation, seasonal changes in base flow, and seasonal differences in the relations between rainfall and runoff, the flows that were originally defined as storm flows could not, in reality, be ascribed to storms; therefore, rather than report separate storm- and base-flow loads in this report, storm- and base-flow loads were summed to yield a single estimate of total load during each 2-week compositing period.

The sampling sequence triggered by the data logger was as follows: (1) determine the flow condition (base or storm flow); (2) calculate that the trigger volume had been reached; (3) collect three equal, sequential volumes of water (about 100 milliliters [mL] each), the first of which was filtered through a large-capacity 0.45 -micrometer $(\mu \mathrm{m})$ capsule filter; (4) composite each sample into its proper bottle; and (5) back flush the sample line. Each of the three sequential samples was deposited into one of three large polyethylene sample-collection bottles - one for whole-water chemical 
Table 1. Monitoring stations in the Blackstone River Basin, Massachusetts and Rhode Island, and data-collection information.

[USGS, U.S. Geological Survey; ID, identification number; River mile, distance upstream from river mouth; DO, dissolved oxygen; WWTP, wastewater treatment $\mathrm{X}$, method was used; NA, not available]

\begin{tabular}{|c|c|c|c|c|c|}
\hline USGS station ID & Station name & Description of station location & $\begin{array}{l}\text { Latitude } \\
\text { (decimal } \\
\text { degrees) }\end{array}$ & $\begin{array}{l}\text { Longitude } \\
\text { (decimal } \\
\text { degrees) }\end{array}$ & $\begin{array}{c}\text { River } \\
\text { mile }\end{array}$ \\
\hline 01109659 & Blackstone River Millbury upstream & $\begin{array}{l}\text { Railroad yard at intersection of Route } 146 \text { and } \\
\text { I-90, Millbury, MA }\end{array}$ & 42.20833 & -71.78222 & 44.7 \\
\hline 01109730 & $\begin{array}{l}\text { Blackstone River Millbury down- } \\
\text { stream }\end{array}$ & West Main Street, Millbury, MA & 42.18898 & -71.76507 & 42.0 \\
\hline 01109852 & Blackstone River Wilkinsonville & Depot Road, Wilkinsonville village, Sutton, MA & 42.17722 & -71.72056 & 38.6 \\
\hline 01110095 & Quinsigamond River & Pleasant Street, Grafton, MA & 42.19861 & -71.69361 & 36.8 \\
\hline 01110400 & $\begin{array}{l}\text { Blackstone River South Grafton } \\
\text { (Rockdale Pond upstream) }\end{array}$ & $\begin{array}{l}\text { Upstream of Rockdale Pond, Fairview Cemetery, } \\
0.8 \text { miles downstream of Depot Street, South } \\
\text { Grafton, MA }\end{array}$ & 42.16528 & -71.67167 & 34.0 \\
\hline 01110500 & Rockdale Pond downstream & $\begin{array}{l}\text { Downstream of Rockdale Pond on the Blackstone } \\
\text { River, Sutton Street, Northbridge, MA }\end{array}$ & 42.15371 & -71.65201 & 32.6 \\
\hline 01110530 & Rice City Pond upstream & $\begin{array}{l}\text { Upstream of Rice City Pond on the Blackstone } \\
\text { River, } 1.2 \text { miles upstream of East Hartford } \\
\text { Road, Northbridge, MA }\end{array}$ & 42.11167 & -71.62472 & 29.2 \\
\hline 01110535 & Rice City Pond outlet & $\begin{array}{l}\text { Downstream of Rice City Pond on the Blackstone } \\
\text { River, East Hartford Road, Uxbridge, MA }\end{array}$ & 42.09833 & -71.62222 & 27.8 \\
\hline 01111050 & Mumford River & Depot Street, Uxbridge, MA & 42.07510 & -71.62479 & 25.9 \\
\hline 01111208 & West River & Hecla Street, Uxbridge, MA & 42.07056 & -71.60861 & 24.2 \\
\hline 01111212 & Blackstone River Uxbridge & Route 122 bridge, Uxbridge, MA & 42.05482 & -71.61645 & 23.2 \\
\hline 01111230 & Blackstone River Millville & Railroad bridge near Route 122, Millville, MA & 42.02288 & -71.57229 & 19.2 \\
\hline 01113895 & Blackstone River Pawtucket & Roosevelt Street, Pawtucket, RI & 41.88871 & -71.38144 & 2.0 \\
\hline 420215071365301 & Uxbridge WWTP & Uxbridge wastewater treatment plant & NA & NA & 21.3 \\
\hline 420647071380801 & Northbridge WWTP & Northbridge wastewater treatment plant & NA & NA & 29.2 \\
\hline 421020071404401 & Grafton WWTP & Grafton wastewater treatment plant & NA & NA & 35.4 \\
\hline 421241071472701 & UBWPAD WWTP & $\begin{array}{l}\text { Upper Blackstone Water Pollution Abatement } \\
\text { District wastewater treatment plant }\end{array}$ & NA & NA & 44.4 \\
\hline
\end{tabular}


plant; UBWPAD, Upper Blackstone Water Polution Abatement District; MA, Massachusetts; RI, Rhode Island; EWI, equal width increment;

\begin{tabular}{|c|c|c|c|c|c|c|c|c|c|c|c|c|}
\hline \multirow[b]{2}{*}{ Data collection methods } & \multirow[b]{2}{*}{$\begin{array}{l}\text { Starting } \\
\text { date }\end{array}$} & \multirow[b]{2}{*}{$\begin{array}{l}\text { Ending } \\
\text { date }\end{array}$} & \multicolumn{5}{|c|}{ Field parameters } & \multicolumn{2}{|c|}{ Nutrients } & \multicolumn{2}{|c|}{ Metals } & \multirow[b]{2}{*}{$\begin{array}{l}\text { Sus- } \\
\text { pended } \\
\text { sedi- } \\
\text { ment }\end{array}$} \\
\hline & & & pH & DO & $\begin{array}{l}\text { Specific } \\
\text { conduc- } \\
\text { tance }\end{array}$ & $\begin{array}{l}\text { Water } \\
\text { tem- } \\
\text { pera- } \\
\text { ture }\end{array}$ & $\begin{array}{l}\text { Tur- } \\
\text { bid- } \\
\text { ity }\end{array}$ & $\begin{array}{l}\text { Fil- } \\
\text { tered } \\
\text { water } \\
\text { sample }\end{array}$ & $\begin{array}{c}\text { Whole } \\
\text { water } \\
\text { (unfil- } \\
\text { tered) } \\
\text { sample }\end{array}$ & $\begin{array}{l}\text { Fil- } \\
\text { tered } \\
\text { water } \\
\text { sample }\end{array}$ & $\begin{array}{c}\text { Whole } \\
\text { water } \\
\text { (unfil- } \\
\text { tered) } \\
\text { sample }\end{array}$ & \\
\hline $\begin{array}{l}\text { 2-week composite by } \\
\text { automated water sampler } \\
\text { and EWI }\end{array}$ & $5 / 31 / 2007$ & $9 / 29 / 2009$ & $\mathrm{X}$ & $\mathrm{X}$ & $\mathrm{X}$ & $\mathrm{X}$ & & $\mathrm{X}$ & $\mathrm{X}$ & & & $\mathrm{X}$ \\
\hline $\begin{array}{l}\text { 2-week composite by } \\
\text { automated water sampler } \\
\text { and EWI }\end{array}$ & $7 / 24 / 2007$ & 9/29/2009 & $\mathrm{X}$ & $\mathrm{X}$ & $X$ & $\mathrm{X}$ & & $\mathrm{X}$ & $\mathrm{X}$ & & & $\mathrm{X}$ \\
\hline $\begin{array}{l}\text { 2-week composite by } \\
\text { automated water sampler } \\
\text { and EWI }\end{array}$ & $8 / 28 / 2007$ & 9/29/2009 & $\mathrm{X}$ & $\mathrm{X}$ & $\mathrm{X}$ & $\mathrm{X}$ & & $\mathrm{X}$ & $\mathrm{X}$ & & & $X$ \\
\hline $\begin{array}{l}\text { 2-week composite by } \\
\text { automated water sampler } \\
\text { and EWI }\end{array}$ & $5 / 29 / 2007$ & $9 / 28 / 2009$ & $\mathrm{X}$ & $\mathrm{X}$ & $\mathrm{X}$ & $\mathrm{X}$ & & $\mathrm{X}$ & $\mathrm{X}$ & & & $\mathrm{X}$ \\
\hline $\begin{array}{l}\text { 2-week composite by auto- } \\
\text { mated water sampler and } \\
\text { Sonde and EWI }\end{array}$ & $8 / 28 / 2007$ & $9 / 29 / 2009$ & $\mathrm{X}$ & $\mathrm{X}$ & $\mathrm{X}$ & $\mathrm{X}$ & $\mathrm{X}$ & $\mathrm{X}$ & $\mathrm{X}$ & $\mathrm{X}$ & $\mathrm{X}$ & $\mathrm{X}$ \\
\hline Sonde and EWI & $3 / 17 / 2008$ & $9 / 22 / 2008$ & $\mathrm{X}$ & $\mathrm{X}$ & $\mathrm{X}$ & $X$ & $\mathrm{X}$ & $\mathrm{X}$ & $\mathrm{X}$ & $X$ & $\mathrm{X}$ & $\mathrm{X}$ \\
\hline Sonde and EWI & $3 / 18 / 2008$ & $9 / 24 / 2008$ & $\mathrm{X}$ & $\mathrm{X}$ & $\mathrm{X}$ & $\mathrm{X}$ & $\mathrm{X}$ & $\mathrm{X}$ & $\mathrm{X}$ & $\mathrm{X}$ & $\mathrm{X}$ & $\mathrm{X}$ \\
\hline Sonde and EWI & $3 / 18 / 2008$ & $9 / 24 / 2008$ & $X$ & $X$ & $X$ & $X$ & $X$ & $\mathrm{X}$ & $X$ & $X$ & $X$ & $\mathrm{X}$ \\
\hline $\begin{array}{l}\text { 2-week composite by } \\
\text { automated water sampler } \\
\text { and EWI }\end{array}$ & $5 / 29 / 2007$ & $9 / 30 / 2009$ & $\mathrm{X}$ & $X$ & $\mathrm{X}$ & $\mathrm{X}$ & & $\mathrm{X}$ & $X$ & & & $\mathrm{X}$ \\
\hline $\begin{array}{l}\text { 2-week composite by } \\
\text { automated water sampler } \\
\text { and EWI }\end{array}$ & $5 / 30 / 2007$ & $9 / 30 / 2009$ & $\mathrm{X}$ & $\mathrm{X}$ & $X$ & $\mathrm{X}$ & & $\mathrm{X}$ & $\mathrm{X}$ & & & $\mathrm{X}$ \\
\hline $\begin{array}{l}\text { 2-week composite by } \\
\text { automated water sampler } \\
\text { and EWI }\end{array}$ & $5 / 30 / 2007$ & $9 / 30 / 2009$ & $\mathrm{X}$ & $\mathrm{X}$ & $\mathrm{X}$ & $\mathrm{X}$ & & $\mathrm{X}$ & $\mathrm{X}$ & & & $X$ \\
\hline $\begin{array}{l}\text { 2-week composite by } \\
\text { automated water sampler } \\
\text { and EWI }\end{array}$ & $6 / 4 / 2007$ & $9 / 30 / 2009$ & $\mathrm{X}$ & $X$ & $X$ & $\mathrm{X}$ & $X$ & $\mathrm{X}$ & $X$ & $X$ & $X$ & $X$ \\
\hline $\begin{array}{l}\text { 2-week composite by } \\
\text { automated water sampler } \\
\text { and EWI }\end{array}$ & $9 / 3 / 2008$ & $10 / 1 / 2009$ & & & & & & & $\mathrm{X}$ & & $\mathrm{X}$ & $X$ \\
\hline $\begin{array}{l}\text { 2-week composite by } \\
\text { WWTP staff }\end{array}$ & $5 / 23 / 2007$ & $9 / 16 / 2009$ & & & $\mathrm{X}$ & & & $\mathrm{X}$ & $X$ & & & \\
\hline $\begin{array}{l}\text { 2-week composite by } \\
\text { WWTP staff }\end{array}$ & $5 / 24 / 2007$ & $9 / 16 / 2009$ & & & $X$ & & & $\mathrm{X}$ & $X$ & & & \\
\hline $\begin{array}{l}\text { 2-week composite by } \\
\text { WWTP staff }\end{array}$ & $5 / 24 / 2007$ & $9 / 16 / 2009$ & & & $X$ & & & $\mathrm{X}$ & $X$ & & & \\
\hline $\begin{array}{l}\text { 2-week composite by } \\
\text { WWTP staff }\end{array}$ & $5 / 22 / 2007$ & $9 / 15 / 2009$ & & & $X$ & & & $\mathrm{X}$ & $X$ & & & \\
\hline
\end{tabular}




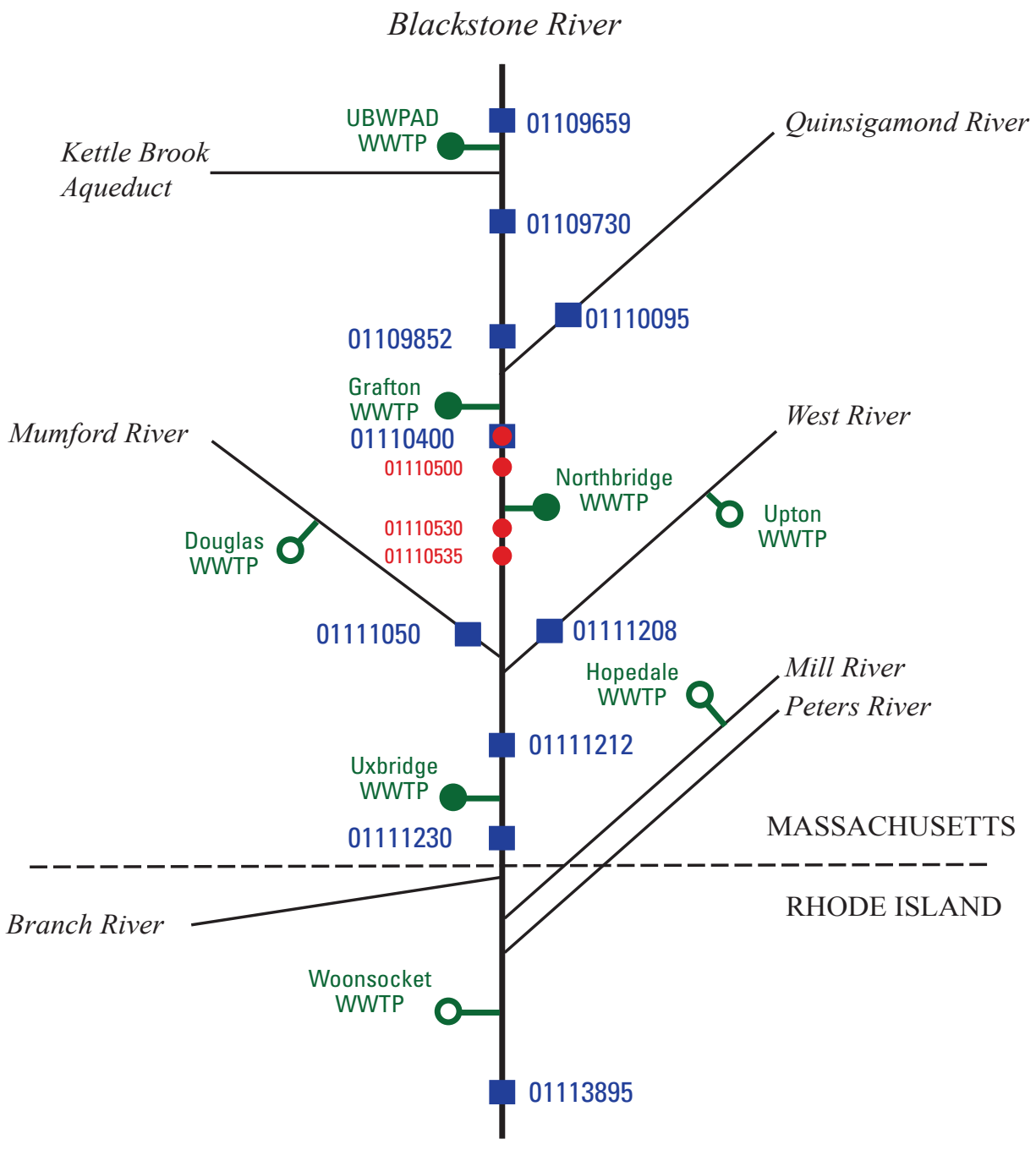

Figure 2. The Blackstone River Basin, Massachusetts and Rhode Island, major tributaries, and wastewater treatment plants. Shown are U.S. Geological Survey streamflow and water-quality monitoring stations where nutrient and suspended sediment loads were measured (blue squares), turbidity and trace element loads were estimated (red dots, upstream and downstream of impoundments), and discharges from wastewater treatment plants (WWTPs; solid green circles) were monitored. WWTPs not monitored for the study in this report are shown as open green circles. UBWPAD, Upper Blackstone Water Pollution Abatement District wastewater treatment plant analysis, one for filtered (or dissolved) chemical analysis, and one for determination of suspended sediment concentration. Inline filtration was used for dissolved fractions because the method reduces the potential for changes in geochemical speciation in samples held for extended periods between sample collection and processing. Sample lines entered the bottles through fittings in the caps so that there would be little evaporation during the compositing period. Whole-water- and filtered-water-sample bottles were stored in either a propaneor electric-powered refrigerator at 4 degrees Celsius $\left({ }^{\circ} \mathrm{C}\right)$ plus or minus $( \pm) 2^{\circ} \mathrm{C}$. The capsule filters were also kept in the refrigerator.

A scaled-down sampling system was used at the Blackstone River Pawtucket monitoring station (01113895). Because real-time filtering was not possible, only wholewater (unfiltered) samples were collected, using methodology similar to that of upstream water-quality monitoring stations. No separate sampling of storm and base flows was conducted; samples were collected in proportion to flow to yield a single composite sample per sampling period. Samples collected at this station were kept cool by packing the sample-collection bottle in ice that was exchanged nearly every other day.

In the field, samples were preserved according to USGS protocols (Wilde and others, 2009), with slight modification. Specifically, sample-collection bottles for the collection of whole-water nutrient and trace element samples were preacidified with 4.5-normal $(\mathrm{N})$ sulfuric acid $\left(\mathrm{H}_{2} \mathrm{SO}_{4}\right)$ instead of $4.5 \mathrm{~N}$ nitric acid $\left(\mathrm{HNO}_{3}\right)$; this modification was followed to avoid contamination of the nutrient sample with nitrogen. Dissolved nutrient samples were not acidified, except at the Blackstone River Millville monitoring station during the period when trace element samples were collected. At the Blackstone River Millville station, because nutrient and trace element samples were composited in the same sample-collection bottle (and the trace element samples required acidification), dissolved nutrient and trace element samples were preacidified with $4.5 \mathrm{~N} \mathrm{H}_{2} \mathrm{SO}_{4}$. Water samples analyzed for suspended sediment concentration do not require preservation and were collected in unacidified, unrefrigerated sample bottles. 


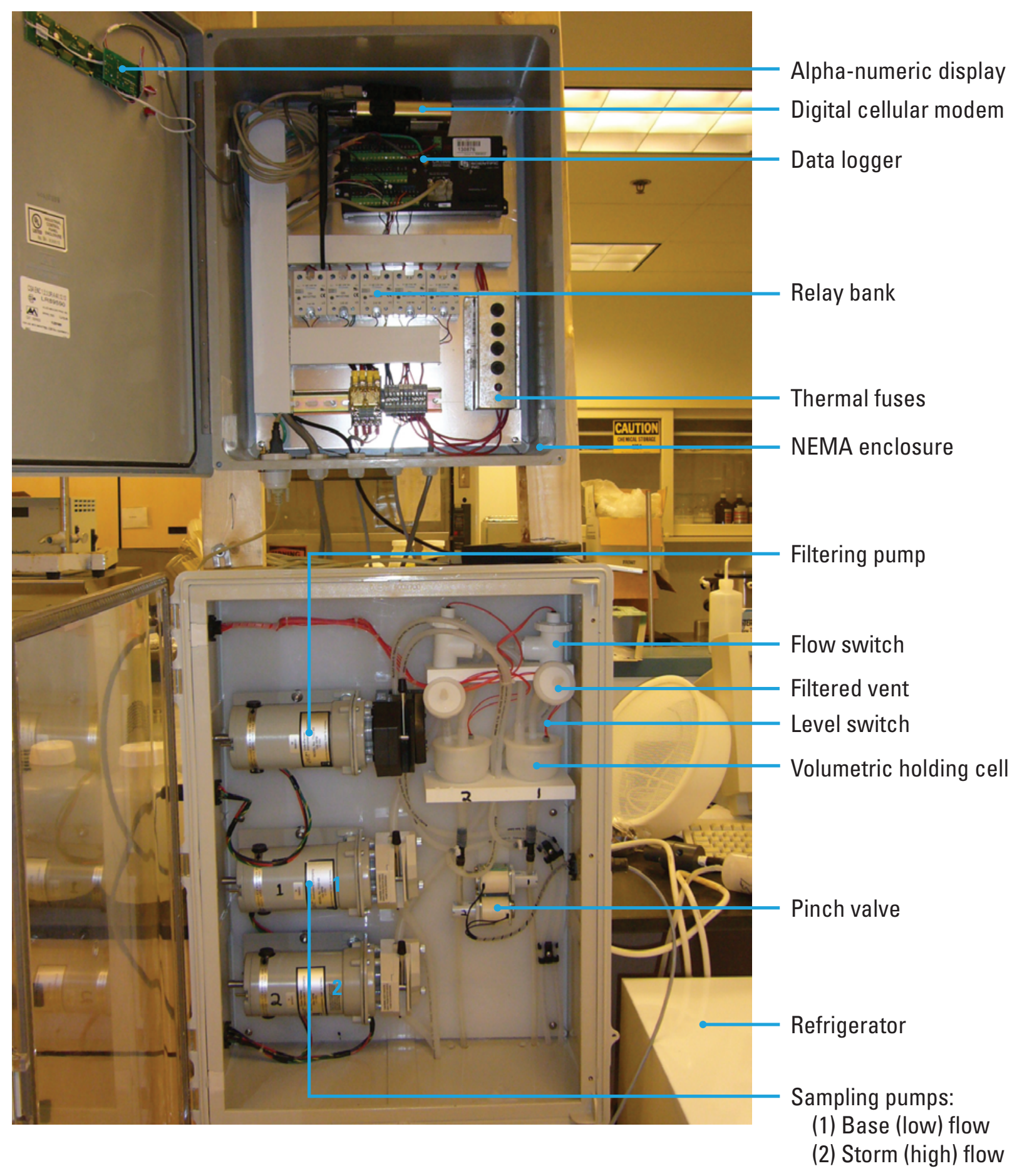

Figure 3. The automated sampling system used in the Blackstone River Basin, Massachusetts and Rhode Island. NEMA, National Electrical Manufacturers Association. 


\section{A. 01109659 Blackstone River Millbury upstream}

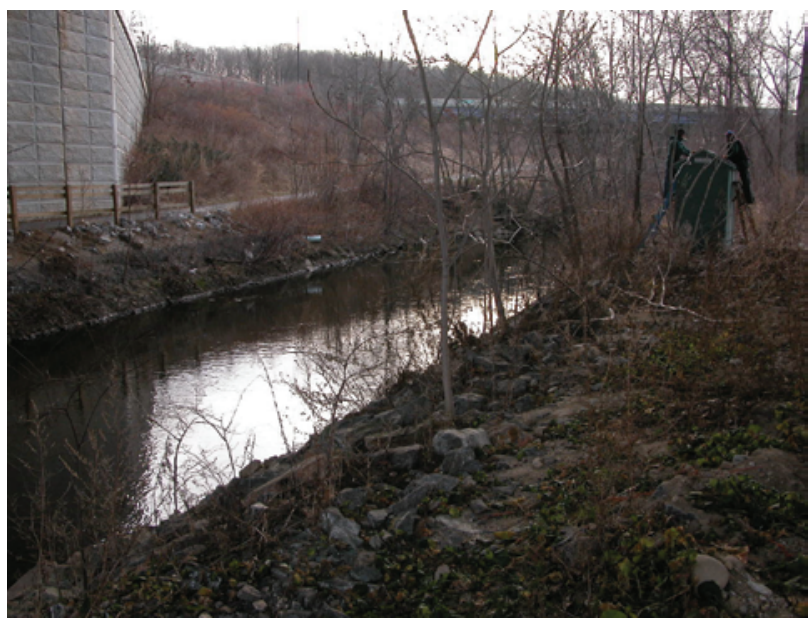

\section{01109852 Blackstone River Wilkinsonville}

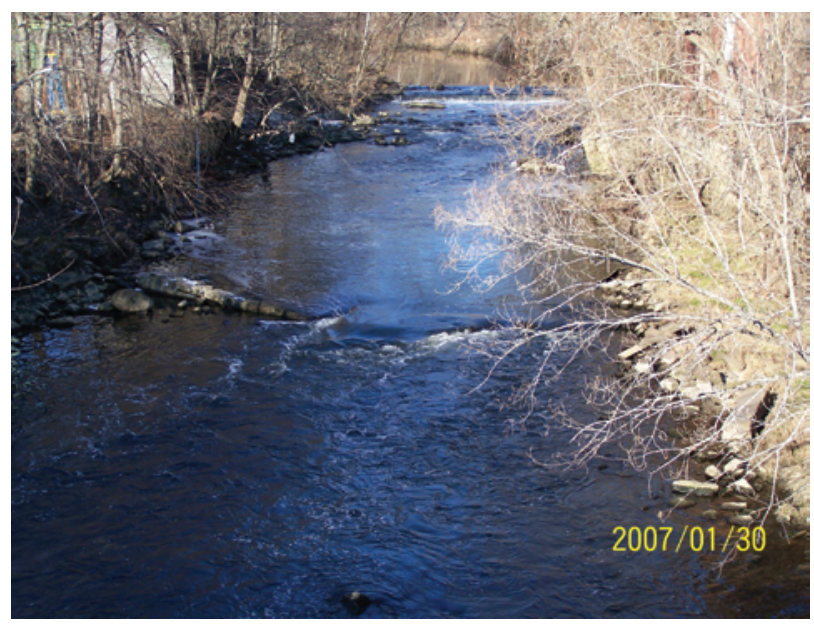

\section{E. 01110400 Blackstone River South Grafton} (Rockdale Pond upstream)

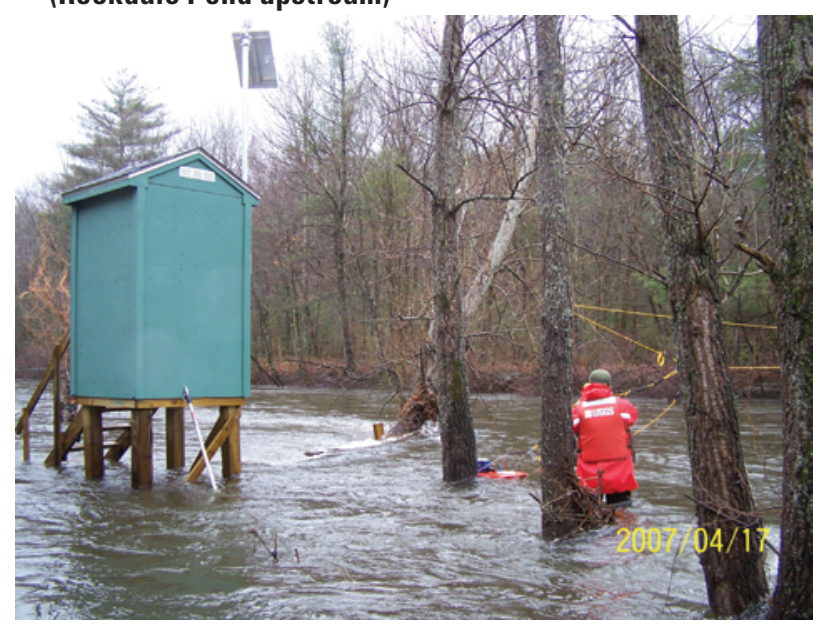

\section{B. 01109730 Blackstone River Millbury downstream}

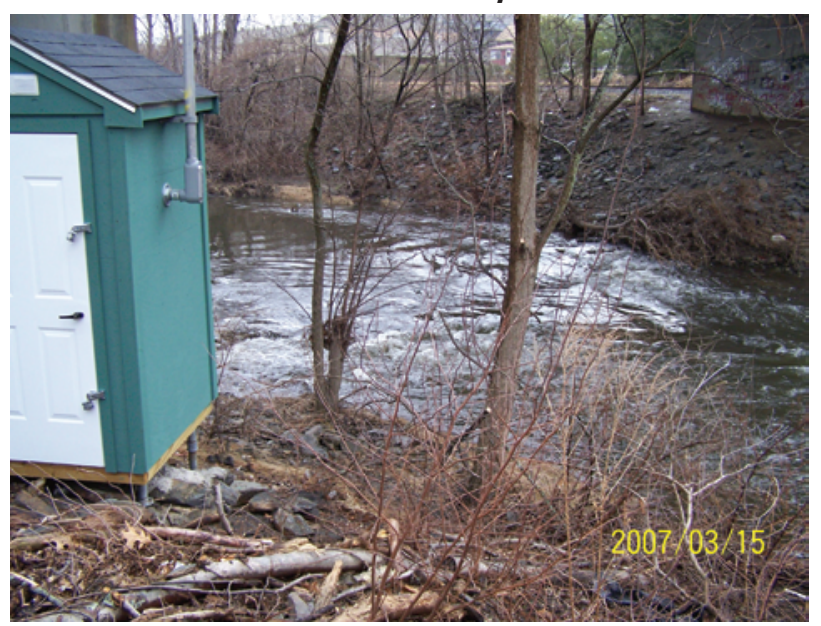

\section{01110095 Quinsigamond River}

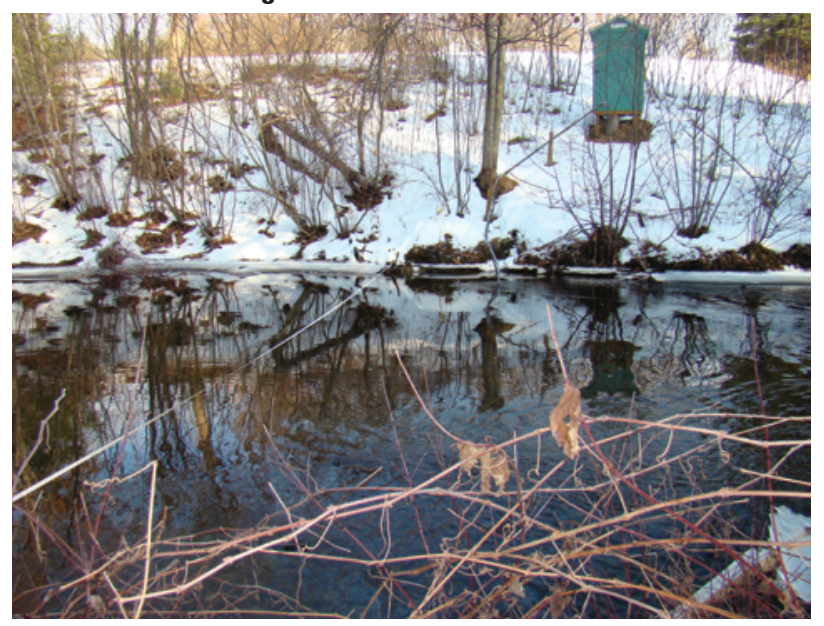

F. 01110500 Rockdale Pond downstream

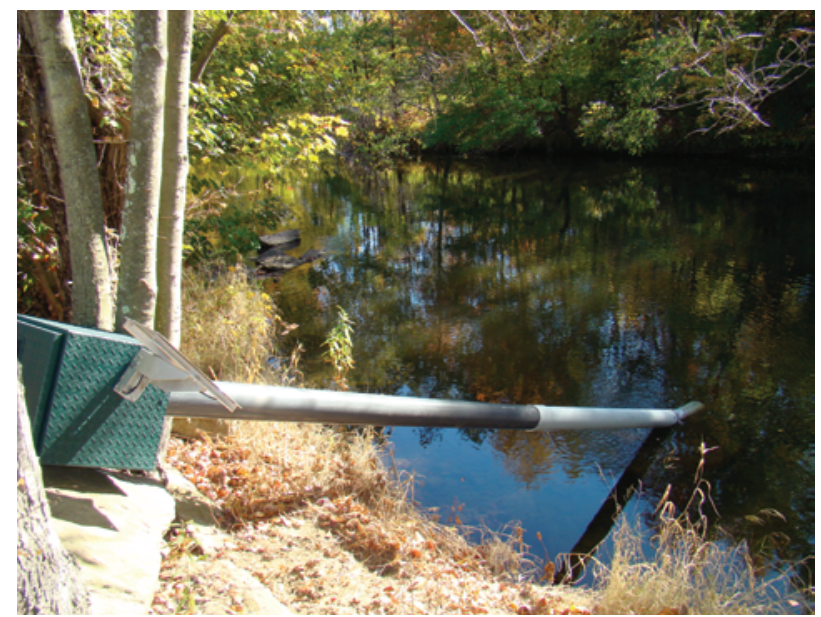

Figure 4. Water-quality- and streamflow-monitoring locations in the Blackstone River Basin in Massachusetts and Rhode Island. 
G. 0111530 Rice City Pond upstream

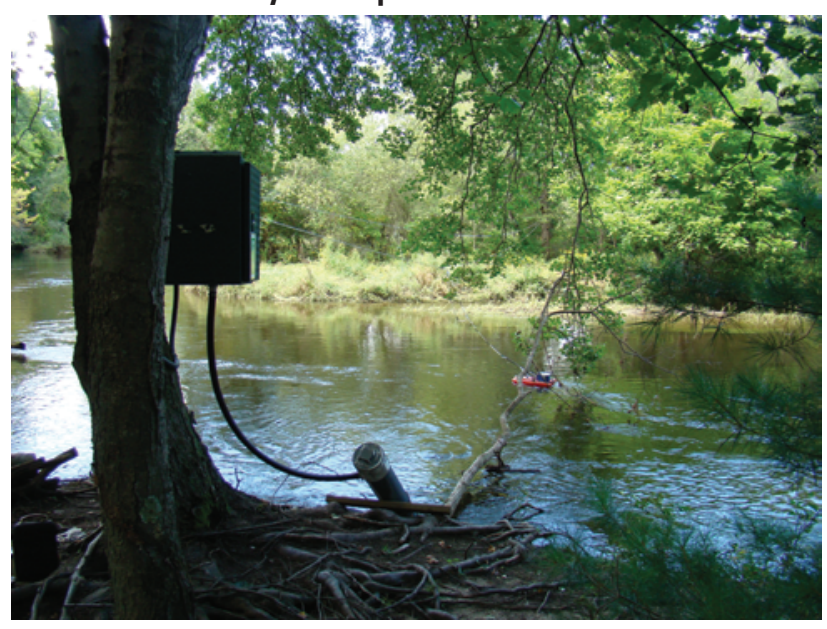

\section{01111050 Mumford River}

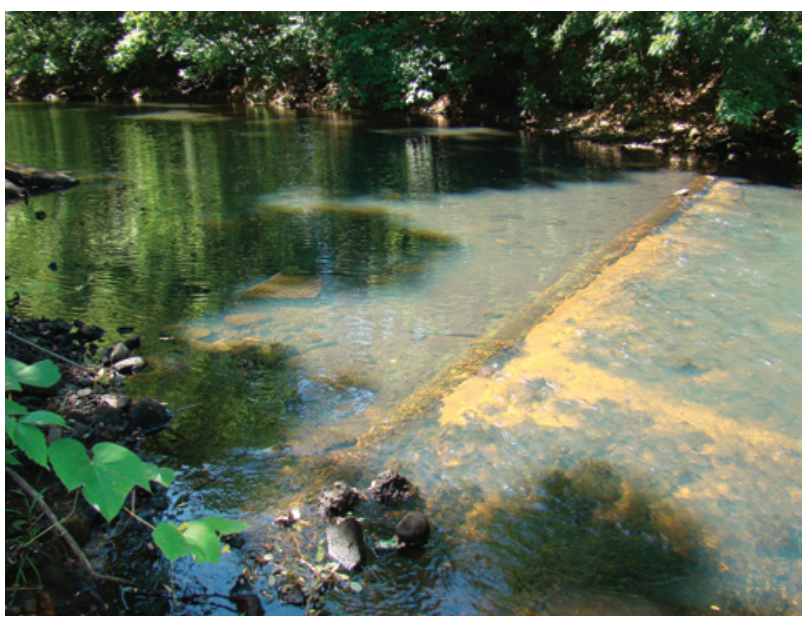

\section{K. 01111212 Blackstone River Uxbridge}

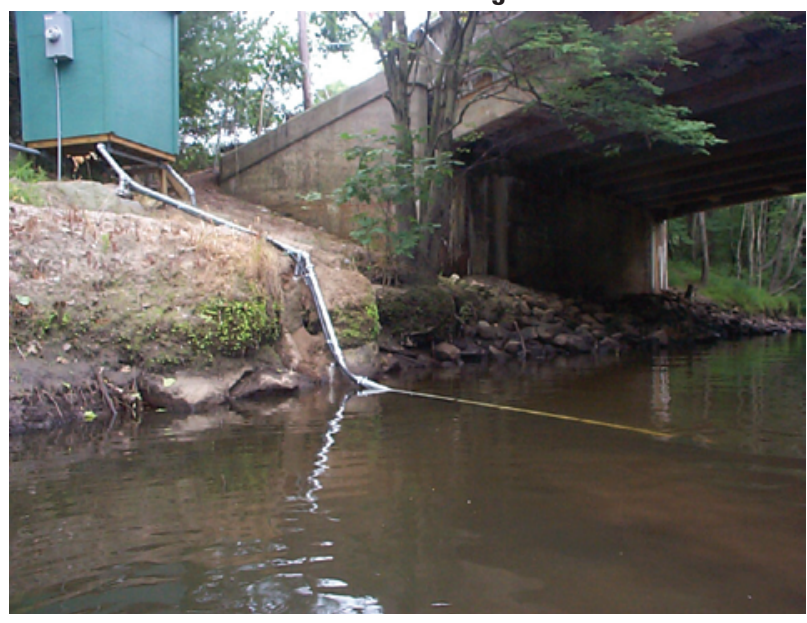

\section{H. 01110535 Rice City Pond outlet}

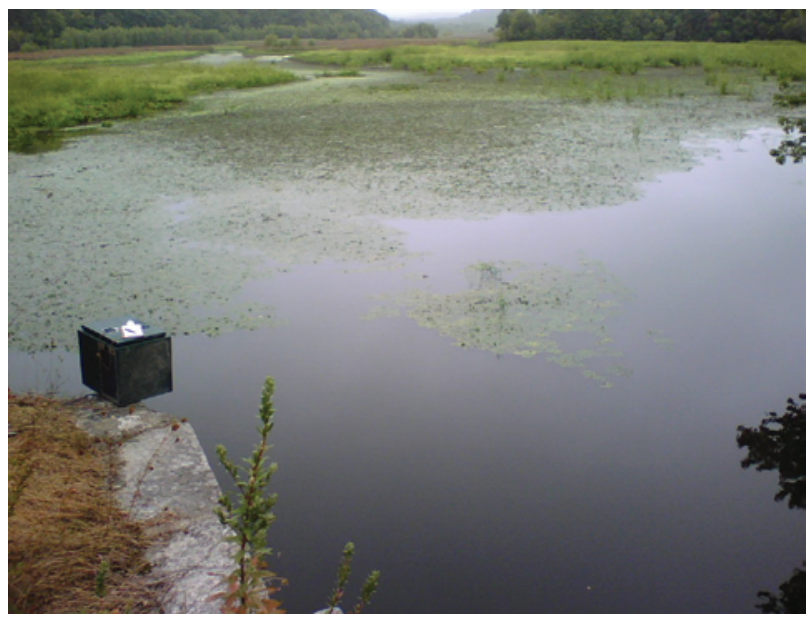

\section{J. 01111208 West River}

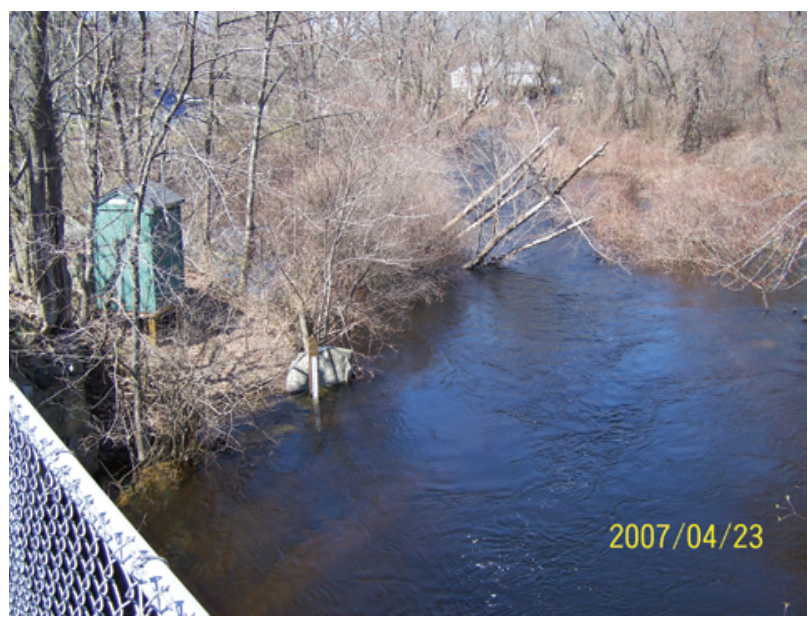

\section{01111230 Blackstone River Millville}

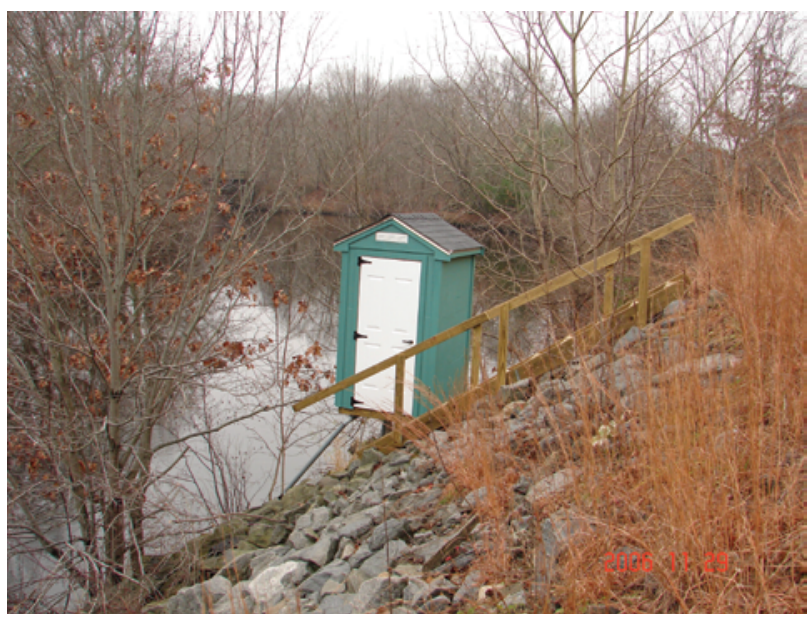

Figure 4. Water-quality- and streamflow-monitoring locations in the Blackstone River Basin in Massachusetts and Rhode Island.-Continued 


\section{01113895 Blackstone River Pawtucket}

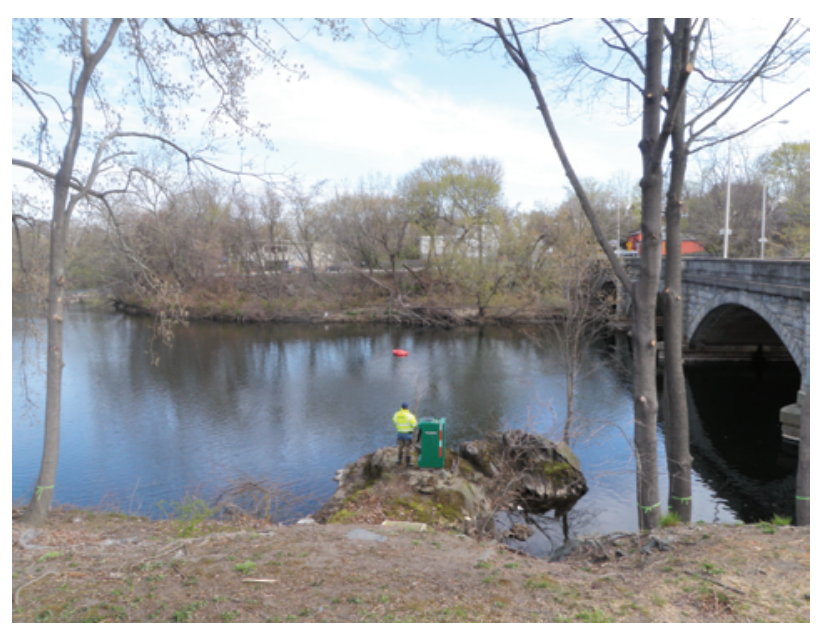

Figure 4. Water-quality- and streamflow-monitoring locations in the Blackstone River Basin in Massachusetts and Rhode Island. - Continued

Modifications were made to the procedures used to preserve whole-water samples during the study in response to ongoing review of analytical data for total nitrogen. Initially (June through December 2007), the volume of acid added to whole-water sample bottles was based on the bottle volume (9 liters [L]), the expectation that bottles could be filled or half-filled, depending on flow conditions, and the sample preservation requirements $\left(1 \mathrm{~mL}\right.$ of $4.5 \mathrm{~N} \mathrm{H}_{2} \mathrm{SO}_{4}$ in a 125-mL sample). Consequently, $72 \mathrm{~mL}$ (or $32 \mathrm{~mL}$ acid with the expectation of a half-filled bottle) was added to the wholewater sample bottles when they were deployed in the field. After several months of sample collection, it was determined that sample bottles at some stations were typically not filled at the end of the sampling period. The volume of acid added to the whole-water sample bottle was reduced by about half at some stations, to $32 \mathrm{~mL}$, to avoid overacidification of the whole-water samples; this change began with some of the sample bottles deployed in January 2008. Overacidification of samples can adversely affect the alkaline-persulfate digestion method for total nitrogen analysis and result in low recovery of inorganic and organic nitrogen (Patton and Kryskalla, 2003). After further review of the analytical data for total nitrogen, the volume of added acid to whole-water sample bottles before the bottles were deployed for sample collection was further reduced to about $5 \mathrm{~mL}$ starting in January 2009 at all stations. After the samples were retrieved from the field, additional acid was added to these whole-water samples while monitoring $\mathrm{pH}$ to achieve the desired level of acidification ( $\mathrm{pH}$ less than 2). The volume of acid added to samples starting in January 2009 was typically about 0.5 percent of the total sample volume.

After approximately 14 days, water-quality samples were retrieved by the USGS, stored on ice, and transported to the Northborough office of the USGS New England Water Science Center. Whole-water, filtered, and suspended sediment base- and storm-flow samples were processed separately. Each sample was subsampled (or split) into appropriate sample bottles as needed to meet requirements for laboratory analysis. Nutrient and trace element samples were split using a polyethylene churn; suspended sediment samples were split using a polycarbonate cone splitter. After processing, samples for analysis of nutrients, trace elements (cadmium, chromium, copper, lead, nickel, and zinc), calcium, magnesium, and specific conductance samples were shipped overnight to the USGS National Water Quality Laboratory (NWQL) in Denver, Colorado; suspended sediment samples were shipped to the USGS Sediment Laboratory in Louisville, Kentucky. Analytical methods are described in Fishman and Friedman (1989), Fishman (1993), Garbarino and Struzeski (1998), Patton and Kryskalla (2003), and Shreve and Downs (2005).

\section{Data Collection for Turbidity}

Instrumentation used to monitor turbidity at four of the streamflow and water-quality monitoring stations consisted of Eureka Manta 2 multiparameter sondes with wiper-equipped McVan turbidity sensors. The sensors used monochrome near infrared (780-900 nanometer [nm]) light projected from light-emitting diodes (LED) at a 90 -degree $\left({ }^{\circ}\right) \pm 2.5^{\circ}$ angle and measured turbidity in formazin nephelometric units (FNU). Turbidity was recorded at intervals of 15 minutes. The sensors were calibrated in the laboratory, and the calibration was checked and adjusted if necessary in the field approximately every 6 weeks during the study period in accordance with 
USGS protocols (Anderson, 2005; Wagner and others, 2006) and manufacturer's specifications.

\section{Manual Water-Quality Sampling}

Equal-width increment (EWI) samples for nutrients, suspended sediment, and trace elements were collected manually according to USGS protocols (U.S. Geological Survey, 2006) at the monitoring stations upstream and downstream of impoundments at stations $01110400,01110500,01110530$, and 0111535 (table 1) for the resuspension study. EWI and concurrent point samples (nine pairs of samples, one to two per station) also were collected at stream monitoring stations over a range of flow conditions; the point samples were collected from the intake of the automatic sampler at a single point in time. The EWI and point samples were collected concurrently to ensure that the point samples represent the entire cross section of the river. Most constituent concentration measurements (80 percent) were in good agreement, with relative percent differences between analytical results in EWI and point measurements of less than 20 percent (appendix 2).

\section{Wastewater Effluent Sampling}

Wastewater effluent samples were collected in 2007, 2008, and 2009, from four wastewater treatment plants that discharge in the Blackstone River Basin in the study area (fig. 1) - the UBWPAD in Millbury and the Grafton, Northbridge, and Uxbridge wastewater treatment plants. Samples were collected to yield a 2-week composite sample of effluent discharge that was timed to match the sampling periods at stream monitoring stations. Eighteen samples at each wastewater treatment plant were collected, for a total of 72 samples (appendix 5). For 14 consecutive days each month, treatment-plant operators collected two $500-\mathrm{mL}$ wastewater effluent samples each day. Sample bottles were supplied to plant operators by the USGS. The sample bottles for total nitrogen and total phosphorus analyses were preacidified with $3 \mathrm{~mL}$ of $4.5 \mathrm{~N} \mathrm{H}_{2} \mathrm{SO}_{4}$. Immediately following collection, samples were refrigerated. The samples collected at the UBWPAD were samples from a daily, flow-composited sample, whereas samples collected at the other treatment plants were grab samples, which were assumed to represent each day's discharge.

After 14 days, the daily flow-proportional samples from the wastewater treatment plants were collected by USGS staff and transported on ice to the USGS laboratory in Northborough. In the laboratory, subsamples (volumes of water from each $125 \mathrm{~mL}$ daily sample bottle) were collected from sample bottles and manually composited to provide samples representative of the 2-week sampling period; the volume of the subsample each day was proportional to daily wastewater treatment plant discharges, as a fraction of the total wastewater treatment plant discharge during the 2-week sampling period. Flow-proportional volumes were determined from daily discharge volumes, which were written on each sample bottle at the time of collection by the treatment-plant operators. Subsamples were collected from each acidified wastewater effluent sample bottle and composited directly in $125-\mathrm{mL}$ polyethylene bottles. Subsamples were collected from each unacidified wastewater effluent sample bottle and composited in 3-L polyethylene bottles; the resulting composited sample was then filtered through a $0.45-\mu \mathrm{m}$ filter and a $125-\mathrm{mL}$ polyethylene bottle was filled with the filtered, composited sample. After processing, nutrient samples were shipped overnight to the NWQL for analysis.

Water-quality samples were not collected at the Woonsocket wastewater treatment plant for this study (fig. 2). Concentration and discharge data provided by the Woonsocket wastewater treatment plant were used to estimate constituent loads from this facility.

\section{Quality-Control Sampling and Data}

This section describes the results of quality-control sampling, including blank and replicate samples, and an investigation into the effects of the 2-week in situ holding time. Quality-control sampling was based on a quality assurance project plan developed before data collection (Robert F. Breault and Kim Campo, U.S. Geological Survey, written commun., 2007).

\section{Blank and Replicate Quality-Control Samples}

Fifteen equipment and (or) preservation blank samples were analyzed to investigate the potential for contamination from the sampling equipment or acid used in sample preservation. The blanks were collected by pouring distilled water or distilled blank water to which preservation acid had been added into composite sample collection bottles and then processed following the procedures described previously for environmental samples. Blanks for wastewater treatment plant samples were poured into four to five wastewater sample collection bottles and composited, as were the daily wastewater samples. All blank samples were collected and processed in the Northborough laboratory. After processing, blank samples were shipped to the NWQL for analysis, as were environmental samples. Results showed that a large majority of the analyses did not have detections of any of the analytes and most of the concentrations of analytes that were detected in blank samples were less than or at their method detection levels (table $2 A$ ). Four analytes were detected in the blank sample associated with the UBWPAD on May 22, 2008; however, the sample bottle used for this blank sample was not rinsed with 5 percent hydrochloric acid, a requirement by USGS protocols (Wilde, 2004). Among the three trace element blanks, two had analyte detections that exceeded the method detection levels. Trace elements were not detected in the third sample. 


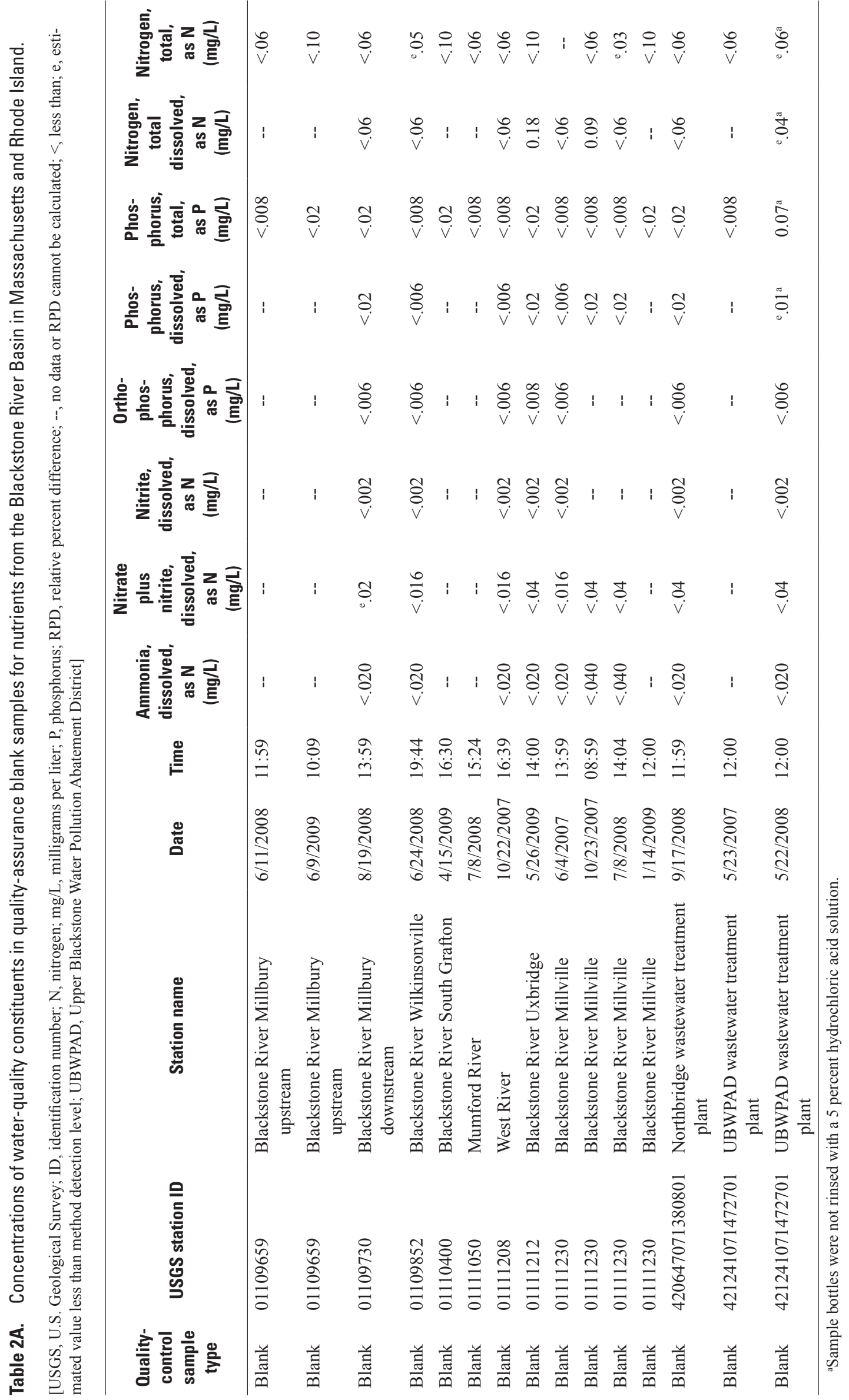


Table 2B. Concentrations of water-quality constituents in replicate samples for nutrients and relative percent differences between environmental-sample concentrations and replicate samples for nutrients from the Blackstone River Basin in Massachusetts and Rhode Island.

[Values in bold indicate values exceeding performance criteria. mg/L, milligrams per liter; N, nitrogen; P, phosphorus; USGS, U.S. Geological Survey; RPD, relative percent difference; e, estimated value less than method detection level; <, less than; --, no data or RPD cannot be calculated]

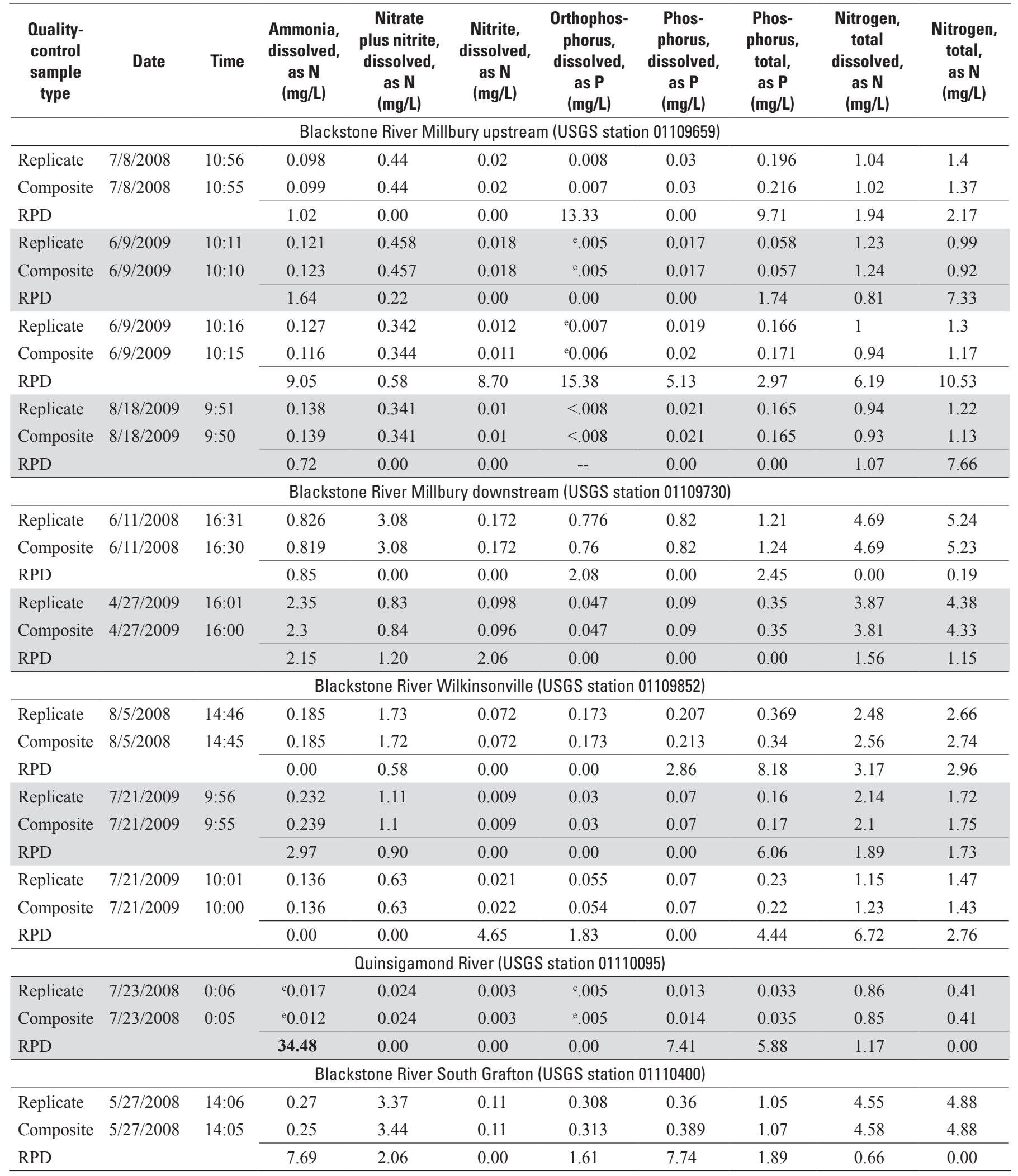


Table 2B. Concentrations of water-quality constituents in replicate samples for nutrients and relative percent differences between environmental-sample concentrations and replicate samples for nutrients from the Blackstone River Basin in Massachusetts and Rhode Island.-Continued

[Values in bold indicate values exceeding performance criteria. mg/L, milligrams per liter; N, nitrogen; P, phosphorus; USGS, U.S. Geological Survey; RPD, relative percent difference; e, estimated value less than method detection level; <, less than; --, no data or RPD cannot be calculated]

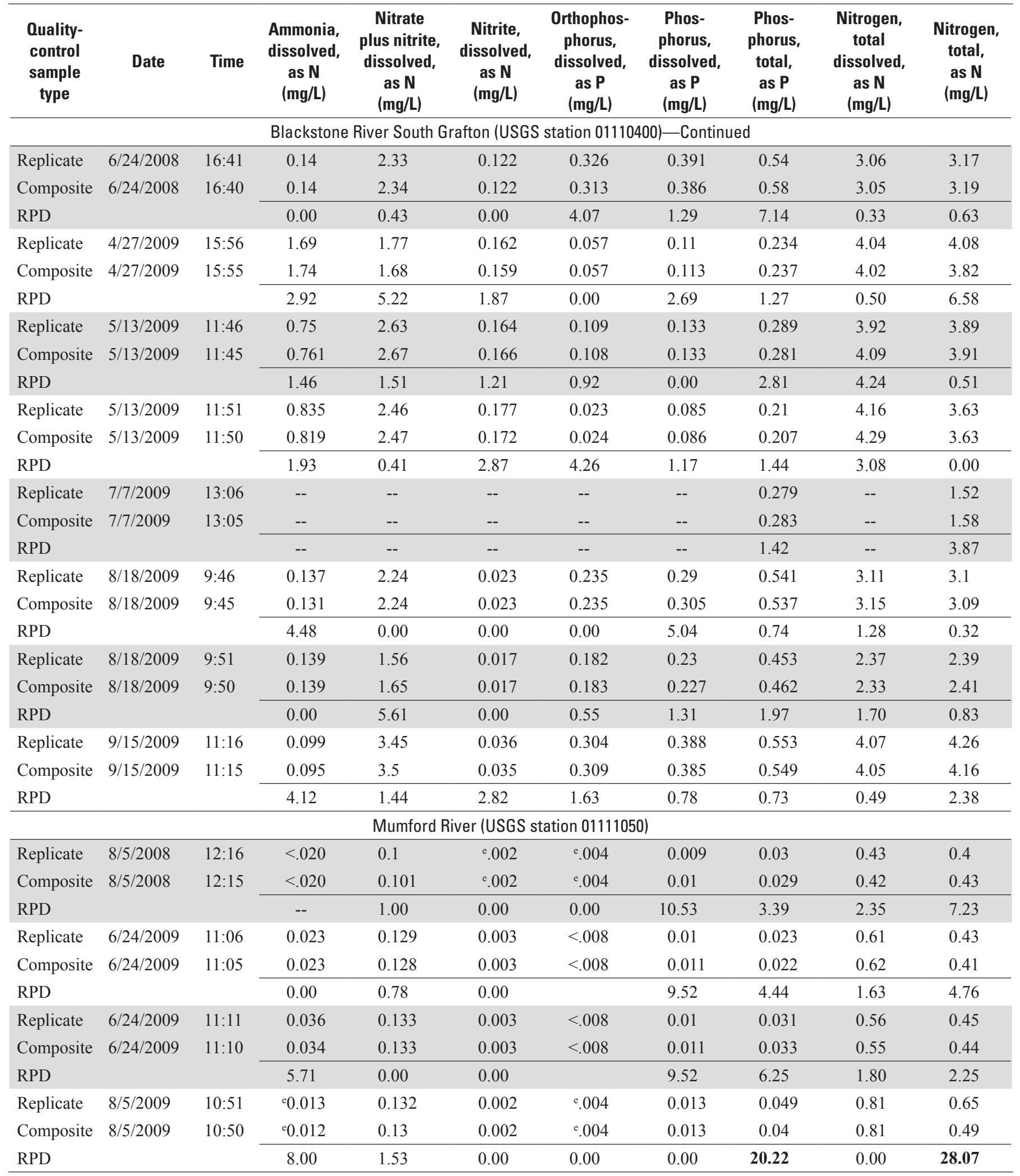


Table 2B. Concentrations of water-quality constituents in replicate samples for nutrients and relative percent differences between environmental-sample concentrations and replicate samples for nutrients from the Blackstone River Basin in Massachusetts and Rhode Island.-Continued

[Values in bold indicate values exceeding performance criteria. mg/L, milligrams per liter; N, nitrogen; P, phosphorus; USGS, U.S. Geological Survey; RPD, relative percent difference; e, estimated value less than method detection level; <, less than; --, no data or RPD cannot be calculated]

\begin{tabular}{|c|c|c|c|c|c|c|c|c|c|c|}
\hline $\begin{array}{l}\text { Quality- } \\
\text { control } \\
\text { sample } \\
\text { type }\end{array}$ & Date & Time & $\begin{array}{c}\text { Ammonia, } \\
\text { dissolved, } \\
\text { as N } \\
\text { (mg/L) }\end{array}$ & $\begin{array}{c}\text { Nitrate } \\
\text { plus nitrite, } \\
\text { dissolved, } \\
\text { as N } \\
\text { (mg/L) }\end{array}$ & $\begin{array}{c}\text { Nitrite, } \\
\text { dissolved, } \\
\text { as N } \\
\text { (mg/L) }\end{array}$ & $\begin{array}{c}\text { Orthophos- } \\
\text { phorus, } \\
\text { dissolved, } \\
\text { as P } \\
\text { (mg/L) }\end{array}$ & $\begin{array}{c}\text { Phos- } \\
\text { phorus, } \\
\text { dissolved, } \\
\text { as P } \\
\text { (mg/L) }\end{array}$ & $\begin{array}{c}\text { Phos- } \\
\text { phorus, } \\
\text { total, } \\
\text { as P } \\
\text { (mg/L) }\end{array}$ & $\begin{array}{c}\text { Nitrogen, } \\
\text { total } \\
\text { dissolved, } \\
\text { as N } \\
\text { (mg/L) }\end{array}$ & $\begin{array}{c}\text { Nitrogen, } \\
\text { total, } \\
\text { as N } \\
(\mathrm{mg} / \mathrm{L})\end{array}$ \\
\hline \multicolumn{11}{|c|}{ Mumford River (USGS station 01111050)—Continued } \\
\hline Replicate & $8 / 5 / 2009$ & $10: 56$ & ${ }^{\mathrm{e}} .020$ & 0.141 & 0.003 & ${ }^{\mathrm{e}} .004$ & 0.013 & 0.118 & 1.37 & 0.87 \\
\hline Composite & $8 / 5 / 2009$ & $10: 55$ & ${ }^{\mathrm{e}} .020$ & 0.14 & 0.003 & $<.008$ & 0.013 & 0.123 & 1.37 & 0.89 \\
\hline RPD & & & 0.00 & 0.71 & 0.00 & -- & 0.00 & 4.15 & 0.00 & 2.27 \\
\hline Replicate & $9 / 2 / 2009$ & 9:31 & $<.020$ & 0.061 & $<.002$ & $<.008$ & 0.007 & 0.02 & 0.55 & 0.32 \\
\hline Composite & $9 / 2 / 2009$ & $9: 30$ & $<.020$ & 0.061 & $<.002$ & $<.008$ & 0.009 & 0.02 & 0.55 & 0.32 \\
\hline RPD & & & -- & 0.00 & -- & -- & 25.00 & 0.00 & 0.00 & 0.00 \\
\hline Replicate & $9 / 2 / 2009$ & $9: 36$ & ${ }^{\mathrm{e}} .010$ & 0.061 & ${ }^{\mathrm{e}} .001$ & $<.008$ & ${ }^{\mathrm{e}} 0.005$ & 0.02 & 0.81 & 0.5 \\
\hline Composite & $9 / 2 / 2009$ & $9: 35$ & ${ }^{\mathrm{e}} .010$ & 0.061 & ${ }^{\mathrm{e} .001}$ & $<.008$ & ${ }^{\mathrm{e}} 0.007$ & 0.019 & 0.77 & 0.51 \\
\hline RPD & & & 0.00 & 0.00 & 0.00 & -- & 33.33 & 5.13 & 5.06 & 1.98 \\
\hline \multicolumn{11}{|c|}{ West River (USGS station 01111208) } \\
\hline Replicate & $5 / 27 / 2009$ & $11: 51$ & ${ }^{\mathrm{e}} 0.012$ & 0.233 & 0.004 & ${ }^{\mathrm{e}} .004$ & 0.013 & 0.029 & 0.93 & 0.74 \\
\hline Composite & $5 / 27 / 2009$ & $11: 50$ & ${ }^{\mathrm{e}} 0.016$ & 0.241 & 0.005 & ${ }^{\mathrm{e}} .004$ & 0.015 & 0.029 & 0.92 & 0.67 \\
\hline RPD & & & 28.57 & 3.38 & 22.22 & 0.00 & 14.29 & 0.00 & 1.08 & 9.93 \\
\hline Replicate & $5 / 27 / 2009$ & $11: 56$ & 0.087 & 0.215 & 0.006 & e.006 & 0.029 & 0.041 & 1.69 & 0.82 \\
\hline Composite & $5 / 27 / 2009$ & $11: 55$ & 0.082 & 0.216 & 0.006 & ${ }^{\mathrm{e}} .006$ & 0.028 & 0.04 & 1.77 & 1.07 \\
\hline RPD & & & 5.92 & 0.46 & 0.00 & 0.00 & 3.51 & 2.47 & 4.62 & 26.46 \\
\hline \multicolumn{11}{|c|}{ Blackstone River Uxbridge (USGS station 01111212) } \\
\hline Replicate & $9 / 2 / 2008$ & 14:26 & 0.057 & 0.82 & 0.034 & 0.085 & 0.11 & 0.32 & 1.39 & 1.49 \\
\hline Composite & $9 / 2 / 2008$ & $14: 25$ & 0.058 & 0.83 & 0.034 & 0.082 & 0.11 & 0.33 & 1.33 & 1.49 \\
\hline RPD & & & 1.74 & 1.21 & 0.00 & 3.59 & 0.00 & 3.08 & 4.41 & 0.00 \\
\hline Replicate & $5 / 14 / 2009$ & $11: 46$ & 0.127 & 1.98 & 0.074 & e.007 & 0.03 & 0.16 & 3.32 & 2.66 \\
\hline Composite & $5 / 14 / 2009$ & $11: 45$ & 0.129 & 1.98 & 0.075 & ${ }^{\mathrm{e}} .007$ & 0.03 & 0.15 & 3.34 & 2.66 \\
\hline RPD & & & 1.56 & 0.00 & 1.34 & 0.00 & 0.00 & 6.45 & 0.60 & 0.00 \\
\hline Replicate & 7/8/2009 & $16: 31$ & 0.199 & 0.75 & 0.021 & 0.008 & 0.04 & 0.26 & 1.64 & 1.37 \\
\hline Composite & $7 / 8 / 2009$ & $16: 30$ & 0.203 & 0.75 & 0.021 & 0.009 & 0.04 & 0.23 & 1.56 & 1.33 \\
\hline RPD & & & 1.99 & 0.00 & 0.00 & 11.76 & 0.00 & 12.24 & 5.00 & 2.96 \\
\hline Replicate & $7 / 8 / 2009$ & $16: 36$ & 0.117 & 0.7 & 0.021 & 0.016 & 0.05 & 0.33 & 1.42 & 1.43 \\
\hline Composite & $7 / 8 / 2009$ & $16: 35$ & 0.112 & 0.7 & 0.02 & 0.016 & 0.04 & 0.29 & 1.38 & 1.23 \\
\hline RPD & & & 4.37 & 0.00 & 4.88 & 0.00 & 22.22 & 12.90 & 2.86 & 15.04 \\
\hline Replicate & $9 / 16 / 2009$ & $10: 51$ & 0.115 & 1.93 & 0.017 & 0.09 & 0.13 & 0.43 & 2.58 & 2.69 \\
\hline Composite & $9 / 16 / 2009$ & $10: 50$ & 0.117 & 1.95 & 0.016 & 0.093 & 0.13 & 0.41 & 2.76 & 2.59 \\
\hline RPD & & & 1.72 & 1.03 & 6.06 & 3.28 & 0.00 & 4.76 & 6.74 & 3.79 \\
\hline \multicolumn{11}{|c|}{ Blackstone River Millville (USGS station 01111230) } \\
\hline Replicate & $6 / 3 / 2008$ & $15: 16$ & 0.033 & 2.12 & 0.061 & 0.167 & 0.17 & 0.25 & 2.75 & 2.54 \\
\hline Composite & $6 / 3 / 2008$ & 15:05 & 0.034 & 2.11 & 0.065 & 0.181 & 0.19 & 0.27 & 2.77 & 2.6 \\
\hline RPD & & & 2.99 & 0.47 & 6.35 & 8.05 & 11.11 & 7.69 & 0.72 & 2.33 \\
\hline
\end{tabular}


Table 2B. Concentrations of water-quality constituents in replicate samples for nutrients and relative percent differences between environmental-sample concentrations and replicate samples for nutrients from the Blackstone River Basin in Massachusetts and Rhode Island.-Continued

[Values in bold indicate values exceeding performance criteria. mg/L, milligrams per liter; N, nitrogen; P, phosphorus; USGS, U.S. Geological Survey; RPD, relative percent difference; e, estimated value less than method detection level; <, less than; --, no data or RPD cannot be calculated]

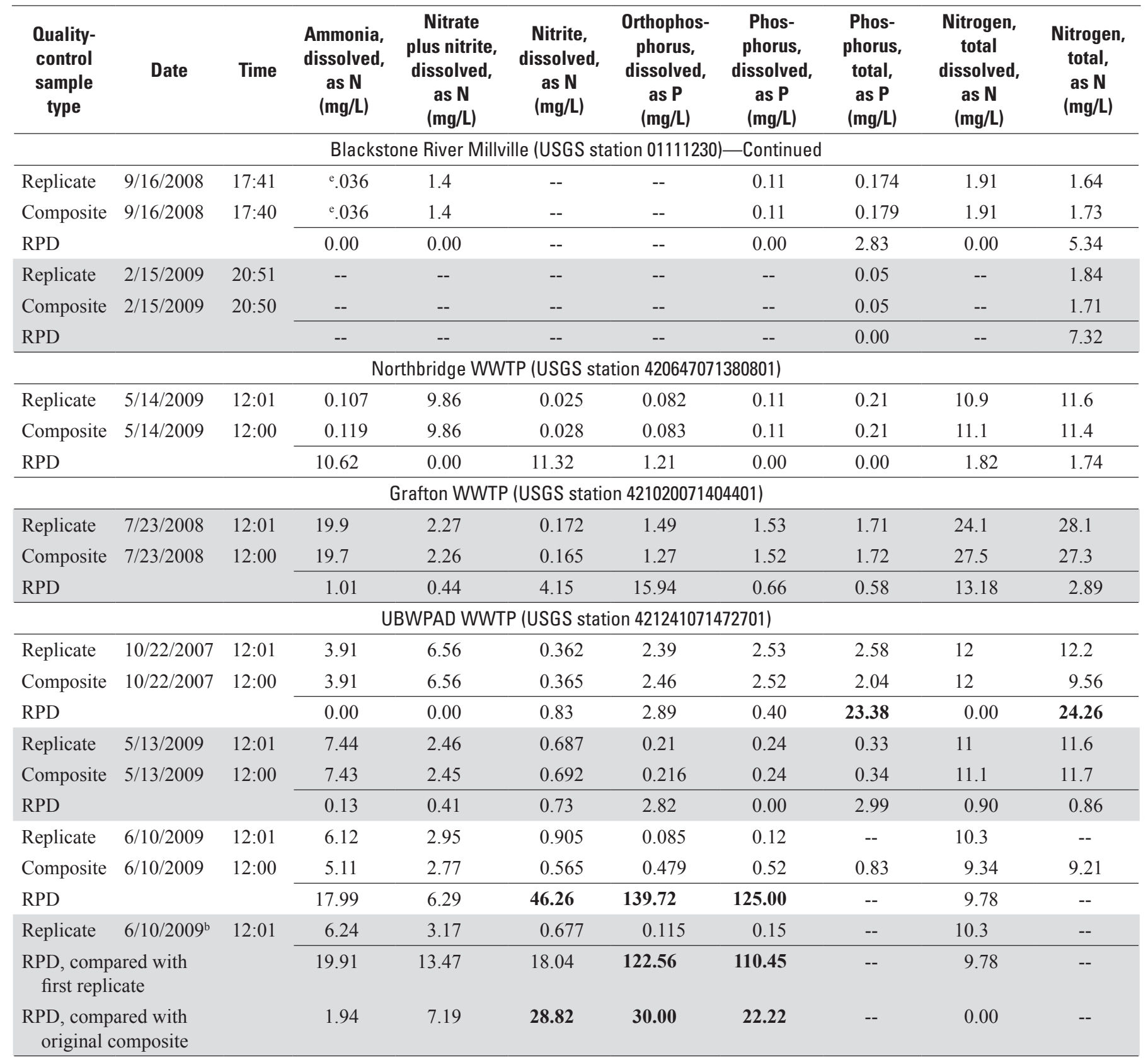

${ }^{\mathrm{b}}$ Second replicate was taken from the refrigerated sample on 7/2/2009. 
Methods 19
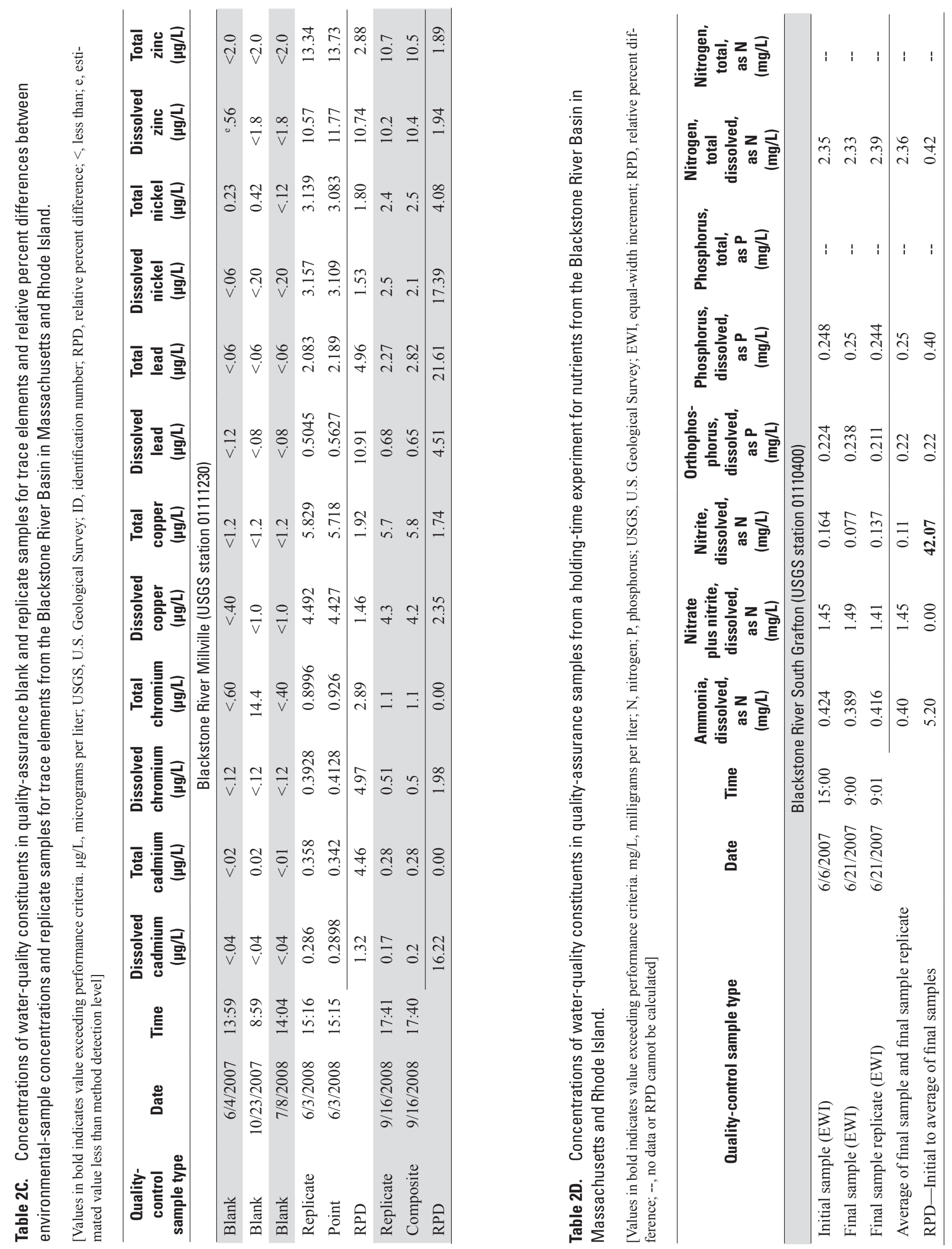


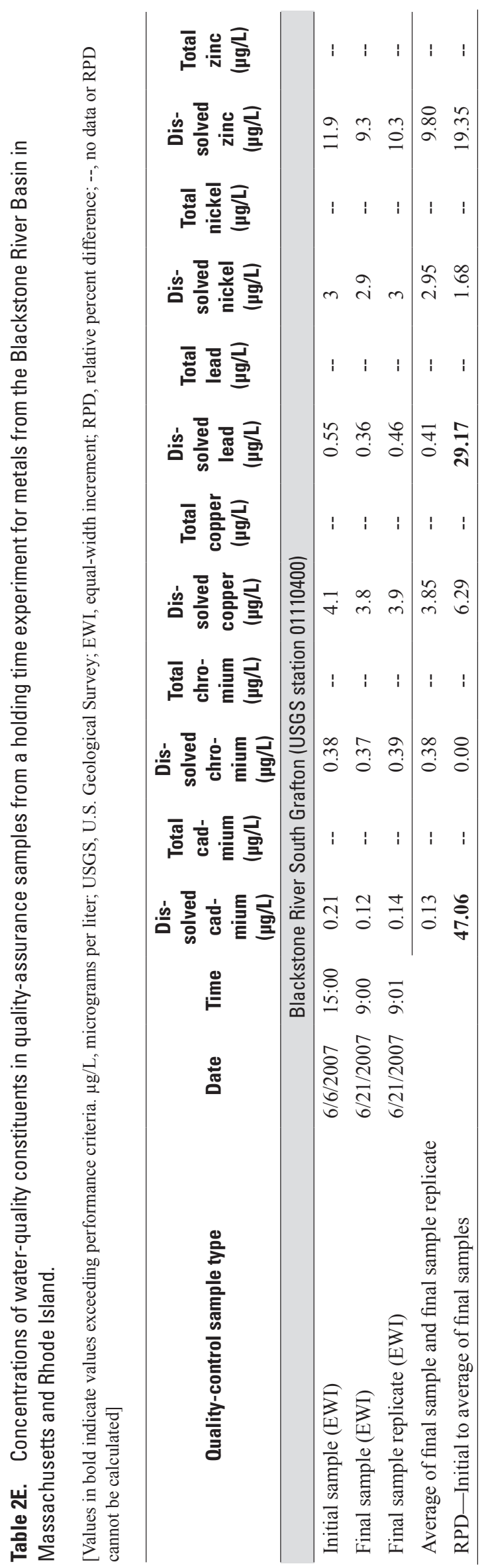


About 40 split-replicate nutrient samples were collected, including samples at all of the stream monitoring stations and from three of the four wastewater treatment plants (table $2 B$ ). Replicates from stream monitoring stations were sequential splits taken from the composite sample bottles; replicates from the wastewater treatment plants were separately composited from the daily sample bottles after the environmental samples were composited. Variability among samples was evaluated using calculated relative percent differences. Few samples showed differences that exceeded the project performance criterion of 20 percent (Robert F. Breault and Kim Campo, U.S. Geological Survey, written commun., 2007), and there were no systematic discrepancies between environmental and replicate samples. Only about 5 percent of all analyses showed differences that exceeded 20 percent; these included a number of analyses with results near the method detection levels, in which small differences corresponded to relatively large percentages of analytical values. The replicate sample collected from the UPWPAD on June 10, 2009, had relative percent differences that exceeded 20 percent for three constituents. A second replicate sample was taken for this sample (which had been kept refrigerated in the laboratory) about 3 weeks later on July 2, 2009 (sample date and time in table $2 B$ is listed as "6/10/2009 12:01"), and had similar analytical values for these constituents as in the first replicate sample; the reasons for the discrepancies between the initial composite sample and the replicate samples is not known.

Two split-replicate samples for trace elements were collected, both from the Blackstone River Millville monitoring station (01111230). The number of replicate samples for trace elements was smaller than the number of replicate samples for nutrients because sampling for trace elements was less extensive than nutrient sampling. The split-replicate samples were from a pair of point samples and a pair of composite samples. Only one of the 12 metals analyzed (total lead in the sample collected on September 16, 2008) exceeded the project performance criterion of a 20 percent difference in concentration (table $2 C$ ).

\section{Effect of Sample Holding Time}

An experiment was performed to investigate the effect of holding the samples in the composite bottles during the 2-week sampling period on analyte concentrations. An EWI sample was collected from the Blackstone River South Grafton station (01110400) on June 6, 2007, for the experiment. An initial subsample was filtered and sent to the NWQL for analysis shortly after collection. The remaining sample water was held refrigerated, unfiltered, and in a carboy that was made up of the same material as the composite bottles, for 14 days. After 14 days (June 21, 2007), a final sample and a final sample replicate were filtered and sent to the NWQL for analysis. Comparison of initial and final analyses showed that concentrations of dissolved nitrogen and phosphorus species, except for nitrite, decreased by less than 10 percent during the 2 -week holding period (table $2 D$ ).
The potential losses of nitrite concentrations are negligible because nitrite concentrations were typically less than 2 percent of total nitrogen concentrations in environmental samples. Similarly, concentrations of dissolved chromium, copper, nickel, and zinc decreased by less than 10 percent relative to initial concentrations. More substantial decreases in concentrations of dissolved cadmium and lead (table 2E) indicated that there may have been losses of these constituents during the 2-week holding period, possibly by sorption onto bottle walls or onto particulates or colloidal material in the sample water. However, these results are not entirely representative of the sampling procedures used in this study in that the experimental sample was held unfiltered during the 2-week period. In the field, composite samples for dissolved constituents, including trace elements, in stream samples were filtered upon collection. The in-situ filtering removed particulates and thus reduced the potential for metals sorption and loss from solution.

\section{Concentration Data and Constituent Load Calculations}

Concentrations of total nitrogen, total phosphorus, suspended sediment, and trace elements in composite, point, and EWI samples from stream monitoring stations and in composite samples from wastewater treatment plants are given in appendixes 1 through 5 . In this section, the use of these data to calculate constituent loads is described.

\section{Concentration Data}

In general, concentrations of nutrients, trace elements, and suspended sediment from samples that are composited over time at stream monitoring stations represent average concentrations during the period in which the samples were collected. When the composite sample is collected using flowproportional sampling, as was done in the study detailed in this report, this average is a flow-weighted average. The study detailed in this report incorporated the added complexity of collecting two composite samples during each sampling period so that average concentrations during the sampling period at stream monitoring stations are represented by two samplesone that was intended to represent concentrations during highflow (storm) conditions, and one that was intended to represent concentrations during low-flow (base-flow) conditions. The fraction of time (and of total streamflow) represented by the high- and low-flow samples differed for each sampling period, depending on the distribution of high- and low-flow conditions in the river during that period. The distribution of high- and low-flow conditions, in turn, was a function of storm events, river regulation, and the stream-stage-based definitions of high and low flow that were programmed into the automated sampler. Consequently, the raw concentration data from composite samples at stream monitoring stations (appendixes 1 and 3) should be interpreted in conjunction with the associated flow 
data to understand concentrations and loads in the streams during the sampling periods. In this report, the concentration data from composite samples are used with flow data to calculate constituent loads.

The attempt to collect separate composite samples representing high- and low-flow conditions required that stream stage and change-in-stage criteria be set for the automated sampler in advance, at the beginning of the sampling period, to distinguish high- and low-flow conditions in the river that might occur during the sampling period. In practice, it was not possible for several reasons to set these criteria with sufficient accuracy to allow consistent sampling of high- and low-flow conditions. First, streamflow regulation by dam operations on the Blackstone River caused unexpected changes in stream stage that were variable and not related to storm events at some monitoring stations. Second, seasonal changes in baseflow levels and station-specific and seasonal differences in rainfall-to-runoff relations could not be adequately accounted for, especially at newly monitored stations that did not have long-term flow records. Consequently, separate high- and low-flow constituent loads were not computed for the study presented in this report. Instead, the high- and low-flow composite samples were combined to yield a single load for each constituent for the entire sampling period. This was possible because the streamflow associated with the subsample for each of the high- and low-flow composite samples was measured and recorded by the automated sampling system. Thus, although the attempt to measure high-(storm-) and low(base-) flow loads was not successful, the composited samples provided flow-proportional representative samples of instream conditions and constituent loads during the sampling periods.

The system design to separate high- and low-flow samples had consequences for the analyzed concentrations of total nitrogen in composite samples, including too much preservation acid in some bottles. Depending on stream stage during the sampling period, a variable number of subsamples was collected from the stream by the automated sampler and composited into the high- or low-flow sample bottles. During sampling periods dominated by high stream stage, for example, more subsamples would be composited into the high-flow bottle and fewer subsamples would be composited into the low-flow bottle, so that the low-flow bottle would have only a small total sample volume at the end of the sampling period; the opposite would occur during sampling periods dominated by low stream stage. The amount of stream water that would be collected in the sample bottles could not be entirely anticipated, because it depended on the weather.

Changes in dam operations, independent of the weather, would also sometimes result in unanticipated changes in stream stage and affect the distribution of subsamples between high- and low-flow conditions. Composite sample bottles sometimes also contained less water at the end of the sampling period than expected because of malfunctions in the sampling process. The composite bottles almost always had adequate sample volume for chemical analyses, but low sample volumes meant that the volume of acid added to whole-water bottles when they were deployed was too much for the final sample (overacidification). This happened consistently to whole-water samples that were collected before January 2009 , in which the percentage of $4.5 \mathrm{~N} \mathrm{H}_{2} \mathrm{SO}_{4}$ in whole water samples was typically 1 percent or more, and occasionally was much larger (the recommended percentage, based on $1 \mathrm{~mL}$ acid per $125 \mathrm{~mL}$ of sample, is 0.8 percent). The problem was recognized and procedures were changed. Starting in January 2009 , the amount of acid added to sample bottles before they were deployed was substantially reduced; additional acid was added after samples were retrieved from the field and while monitoring $\mathrm{pH}$ to achieve the desired level of acidification $(\mathrm{pH}$ less than 2) in the preserved samples. In samples collected after January 2009, the percentage of $4.5 \mathrm{~N} \mathrm{H}_{2} \mathrm{SO}_{4}$ in whole water samples in the field was typically about 0.4 percent, which is less than the recommended value but was sufficient to reduce the $\mathrm{pH}$ of samples in the field to about 4 .

Overacidification of sample water can result in low recovery of inorganic and organic nitrogen by the alkaline persulfate digestion analytical method (Patton and Kryskalla, 2003) for total nitrogen that was used in the study presented in this report. Overacidification likely was a factor in the discrepancies between the analytical results for total nitrogen and total dissolved nitrogen in a large number of composite, whole-water samples from stream monitoring stations (appendix 1). In 45 percent of these composite samples, total nitrogen was less than total dissolved nitrogen by more than 10 percent of the total nitrogen value; 10 percent was considered a conservative maximum value for differences in total and dissolved concentrations due to laboratory analytical error. This discrepancy between total nitrogen and total dissolved nitrogen varied in ways that were consistent with overacidification as a cause; the discrepancy was larger in small-volume samples and in samples with high final percentages of preservation acid. Moreover, only two (4 percent) of the EWI and point samples had differences between total nitrogen and total dissolved nitrogen (total less than dissolved) that exceeded 10 percent; the EWI and point samples were not collected in preacidified bottles and received the appropriate amount of acid for their sample volumes during postsample processing. Similarly, only three (4 percent) of the wastewater samples had differences between total nitrogen and total dissolved nitrogen (total less than dissolved) greater than 10 percent; although collected in preacidified bottles, the volume of the wastewater samples were consistently sufficient so that the preadded acid had little effect.

Although these patterns suggest that overacidification was a factor in the large discrepancies between total nitrogen and total dissolved nitrogen that were observed in composite samples, such discrepancies were not eliminated when preservation procedures were changed in January 2009 to ensure that too much acid was not added. Discrepancies persisted, primarily in composite samples from the monitoring stations on the tributaries (Quinsigamond, Mumford, and West Rivers) rather than in samples from stations on the main stem 
Blackstone River downstream of wastewater treatment plants. There are other possible reasons for low total nitrogen values; in particular, the alkaline persulfate digestion method is known to underestimate total nitrogen concentrations in some whole water samples because of particulate nitrogen that is resistant to the digestion (Rus and others, 2012). This may partly explain why the discrepancies were largest and most frequent in samples from the tributary streams and from the main stem Blackstone River station situated upstream of the wastewater discharges; a larger fraction of the nitrogen in these streams may have been unreactive.

Use of concentration data for total nitrogen from samples in which total nitrogen was considerably less than total dissolved nitrogen was considered unacceptable for load calculations because it was considered unlikely that the total nitrogen values were correct. For all samples in which total nitrogen concentrations were less than dissolved nitrogen concentrations by more than 10 percent of the total nitrogen value, loads were calculated by using the analytical values of total dissolved nitrogen. Analytical values of total dissolved nitrogen concentrations were compared with the sum of analyzed dissolved nitrogen species to verify that the analytical values of total dissolved nitrogen concentrations were reasonable. This approach will underestimate total nitrogen loads for these samples because it does not include particulate nitrogen. However, this was not expected to greatly affect study findings. The majority of the samples in which total nitrogen was less than total dissolved nitrogen by more than 10 percent were from tributaries or the upstream main stem station. Nitrogen loads at tributary station or the upstream main stem station were relatively very small compared with nitrogen loads from wastewater treatment plants or loads at other main stem Blackstone River stations (based on samples in which total nitrogen values were greater than total dissolved nitrogen values). In addition, samples in which total nitrogen was less than total dissolved nitrogen by more than 10 percent tended to represent smaller fractions of the total flow (and thus total load) during the sampling period, especially at main stem stations. Finally, the particulate fraction of the total nitrogen in the river samples does not appear large based on the differences between total and total dissolved nitrogen concentrations in EWI and point samples, which were relatively unaffected by the problem with total nitrogen concentrations at all stations except the Blackstone River Millbury upstream station (01109659; appendix 3).

For sampling periods in which total dissolved nitrogen concentrations exceeded total nitrogen concentrations but by less than 10 percent, total nitrogen concentrations were used to calculate total loads. In some cases, in which total dissolved nitrogen concentrations exceeded total nitrogen concentrations in both low- and high-flow samples, this resulted in total nitrogen loads for the sampling period that were less than total dissolved nitrogen loads. The differences in loads that result from this source are less than 10 percent.

An additional, minor adjustment was made to all concentrations from samples in preacidified bottles. These were the composite samples for analysis of total nitrogen and total phosphorus at all stream monitoring stations (except the Blackstone River Pawtucket station, 01113895) and the composite samples for analysis of dissolved and total analytes at the Blackstone River Millville station (01111230) before November 18, 2008. Analytical concentrations from the NWQL were multiplied by a dilution factor to account for the volume of the preadded acid. Addition of the preservation acid increased the volume of the sample but did not contribute any analytes to the sample. Thus, analytical results for samples to which acid was added were slightly less than actual concentrations in the environmental sample because of the dilution effect of the added volume of the acid. Typically in waterquality analyses, this effect is negligible and is not corrected for. In most samples in this study, where the volumetric percentage of acid was small (less than 2 percent), this correction similarly changed the analytical results by very little. However, as a result of this procedure, concentration data given in appendixes 1, 3, and 5 differ slightly from values stored in the USGS National Water Information System database.

\section{Constituent Loads}

Constituent loads in the composite samples were estimated for all stream monitoring stations and wastewater treatment plants. Constituent loads were calculated by multiplying the total discharge volume during the sampling period by individual constituent concentrations. Total discharge volumes at the monitoring stations (appendix 1) were calculated using the streamflow data collected at 15-minute intervals at each station; the discharges at wastewater treatment plants were calculated from the total daily discharges reported by each wastewater treatment plant. For monitoring stations, each 15-minute streamflow volume was attributed to either the parts of the sampling period when subsamples were being composited into the high-flow sample bottle or to the parts of the sampling period when subsamples were being composited into the low-flow bottle. Streamflow volumes for the entire sampling period were separately totaled for the high- and low-flow parts of the sampling period. The total flow volumes associated with high- or low-flow periods were multiplied by the constituent concentrations in the high- or low-flow sample, respectively, to yield flow-weighted components of total load. The load components associated with the high- and low-flow parts of the sampling period thus calculated were added to yield a single load per sampling period. Loads are reported as daily mean loads (kilogram-per-day).

Where constituent concentrations were unavailable for a particular composite sample and estimates were needed to calculate annual loads for the Blackstone River Millville station (01111230), the average of the loads from the preceding and following samples were substituted. If there were gaps for two sample periods, the average of the preceding and following sample loads was used for both missing loads. If there were gaps of three sample loads (a situation that occurred 
only once), the average of the preceding and following sample loads was used to estimate the load for the second of the three missing samples. Then, the load for the second missing sample was used similarly to calculate an average for the missing previous and following sample loads. Censored data values (concentrations reported as less than method detection limits) were replaced by values equal to one-half the method detection limits.

In all tables and figures, a single starting date is used to designate the time of each sampling period, even though the actual starting and ending dates for the composite samples (appendixes 1,3, and 5) at the individual monitoring stations may have varied by a day or two from these single starting dates. The starting date used in tables and figures reflects the starting date of the first sample collected during the sampling period, except for a few dates when the composite sample at the Blackstone River Pawtucket station started before the sampling period was begun at stations in the Massachusetts segment of the basin. Actual starting and ending dates at individual stations varied because the logistics of operating 9 or 10 monitoring stations for automated sample collection made it impracticable to start and stop sampling on the same date at all the stations. These single starting dates are used to simplify the presentation in text, tables, and figures. Constituent loads for the 2-week sampling periods also were converted to daily mean loads for the period to normalize for some differences in sampling periods among monitoring stations.

Constituent loads (daily mean loads) for examining the effects of sediment resuspension were calculated from estimated constituent concentrations; the concentrations were estimated using turbidity measurements (data collected at 15-minute intervals) and regression analysis of turbidity and concentration in EWI samples. The regression analysis is described in the "Potential for Resuspension and Transport of Trace Element- and Nutrient-Enriched Bottom Sediment From Two Impoundments" section. Constituent loads were calculated as the product of concentration and instantaneous streamflow for the 15-minute interval, and loads for the 15-minute intervals were summed for the day. The average of the 15-minute interval loads was the daily mean load for the day.

\section{Base Flow and Runoff Components of Streamflow}

The base flow and runoff components of streamflow during sampling periods were calculated from daily mean streamflow data at the Blackstone River Millville monitoring station (01111230) using the online software program WebBased Hydrograph Analysis Tool (WHAT; Lim and others, 2005). This program provides several options of methods to determine base flow separation. These methods and their associated parameters were tested to determine which provided the best representation of base flow separation during the entire study period (Phillip J. Zarriello, U.S. Geological
Survey, oral commun., 2012). After the appropriate method and parameters were selected (single parameter, digital filter equal to 0.98 ), they were applied to separate daily mean streamflow for each day of the study period into base flow and runoff (where runoff is calculated as total flow minus base flow). The fraction of total streamflow from base flow in each sampling period was summarized by calculating a base flow index (BFI) for the sampling period. The BFI is equal to the base flow divided by the total streamflow; thus, BFI may range from 1.0 (base flow equals total flow) to 0.0 (no base flow). In this study, an overall BFI was calculated for each sampling period as the sum of total base flow on all days of the sampling period divided by the sum of total streamflow on all days of the sampling period. In addition, the base flow and total flow data generated by WHAT were used to create hydrographs that were combined with hydrographs of antecedent streamflow conditions.

\section{Constituent Loads in the Blackstone River Basin}

Constituent loads in the Blackstone River Basin, including inputs from wastewater treatment plants and tributaries, are described in this section, with the primary focus on nitrogen. Nitrogen, phosphorus, and suspended sediment loads were determined for most monitoring stations, and loads of trace elements were determined for the monitoring station at the Massachusetts-Rhode Island border, in Millville. Loads of total nitrogen and trace elements were determined for the monitoring station near the river's mouth in Pawtucket for the latter part of the study period (September 2008 to September 2009). Loads described in this report, unless otherwise indicated, are daily mean loads based on composite samples collected during approximately 2-week sampling periods.

\section{Nitrogen, Phosphorus, and Suspended Sediment Loads in the Massachusetts Segment of the Blackstone River Basin}

Estimated loads of total nitrogen, total phosphorus, and suspended sediment at seven stream monitoring stations along the main stem Blackstone River, three monitoring stations on tributaries of the Blackstone River, and four wastewater treatment plants on the main stem Blackstone River are the basis for the discussion of constituent loads in this section. Loads at most of these stations were measured during about 262 -week composite sampling periods in summer and early fall 2007 and spring, summer, and early fall 2008 and 2009. Loads of these constituents, along with streamflow at the Blackstone River Millville station, are shown for selected, representative sampling periods in figure 5; loads for all sampling periods are presented in table 3 (at back of report) and appendix 6 . 
Estimated constituent load

Total nitrogen

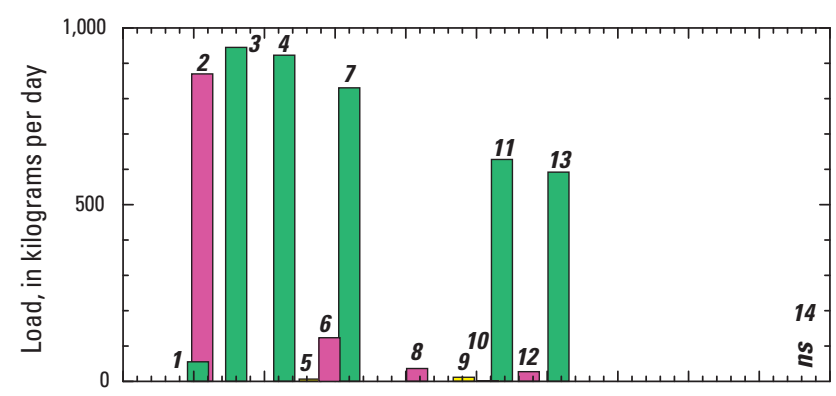

Total phosphorus

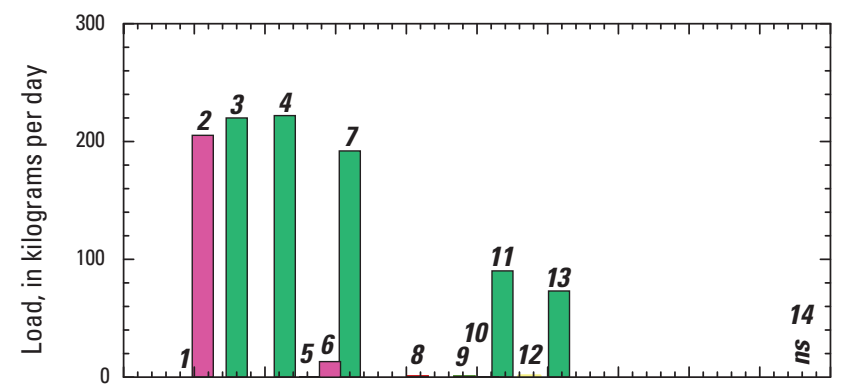

Suspended sediment

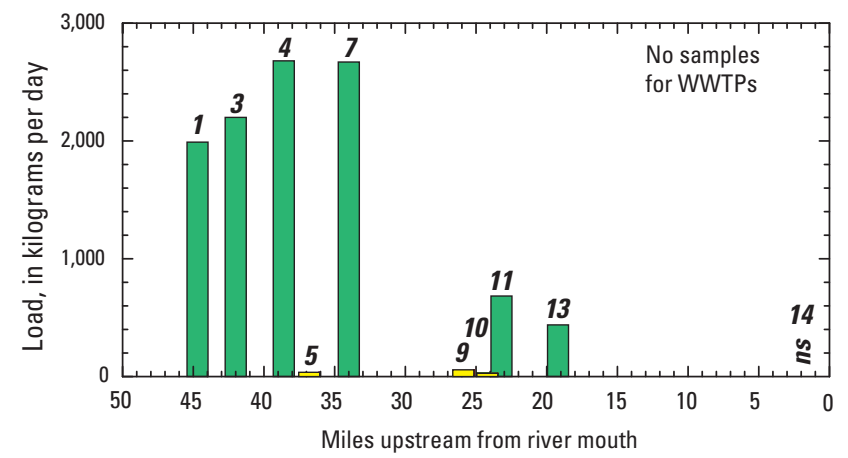

\section{EXPLANATION}

Monitoring station type

$\square$ Mainstem

Wastewater treatment plant (WWTP)

$\square$ Tributary

Monitoring station name (miles upstream from river mouth)

1 Blackstone River Millbury upstream (44.7 mi)

2 UBWPAD WWTP (44.4 mi)

3 Blackstone River Millbury downstream (42.0 mi)

4 Blackstone River Wilkinsonville (38.6 mi)

5 Quinsigamond River (36.8 mi)

6 Grafton WWTP (35.4 mi)

7 Blackstone River South Grafton (34.0 mi)

8 Northbridge WWTP (29.2 mi)

9 Mumford River (25.9 mi)

10 West River (24.2 mi)

11 Blackstone River Uxbridge (23.2 mi)

12 Uxbridge WWTP (21.3 mi)

13 Blackstone River Millville (19.2 mi)

14 Blackstone River Pawcatuck (2 mi)

ns no samples

Streamflow at Blackstone River Millville station

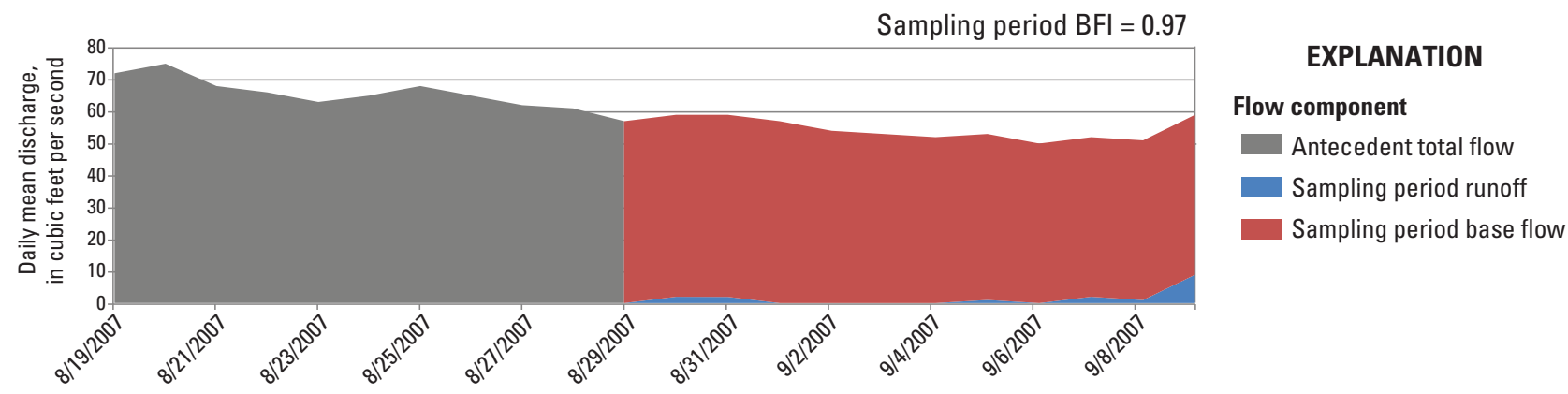

Figure 5. Loads of total nitrogen, total phosphorus, and suspended sediment at stream monitoring stations and wastewater treatment plants (WWTPs) from composite samples in the Blackstone River Basin, Massachusetts and Rhode Island, for the 2-week sampling periods starting A, August 28, 2007, B, April 28, 2008, C, June 24, 2008, D, September 16, 2008, E, May 13, 2009, F, July 7, 2009, and $G$, September 1, 2009. BFI, base-flow index (average during the sampling period); mi, miles; UBWPAD, Upper Blackstone Water Pollution Abatement District. 
B. Sampling period starting April 28, 2008

Estimated constituent load

Total nitrogen

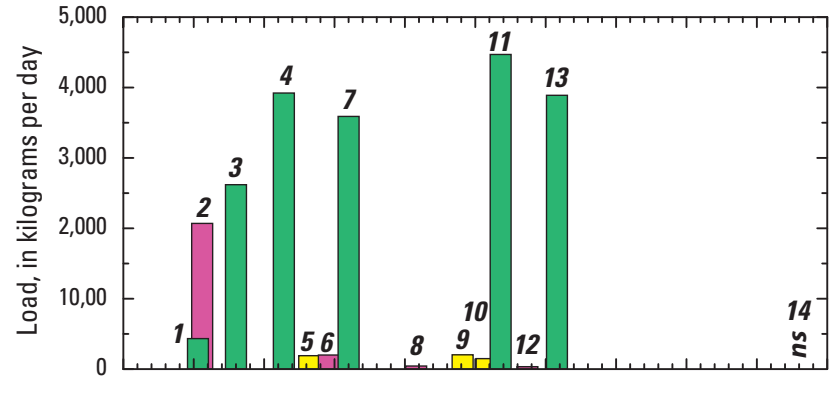

Total phosphorus
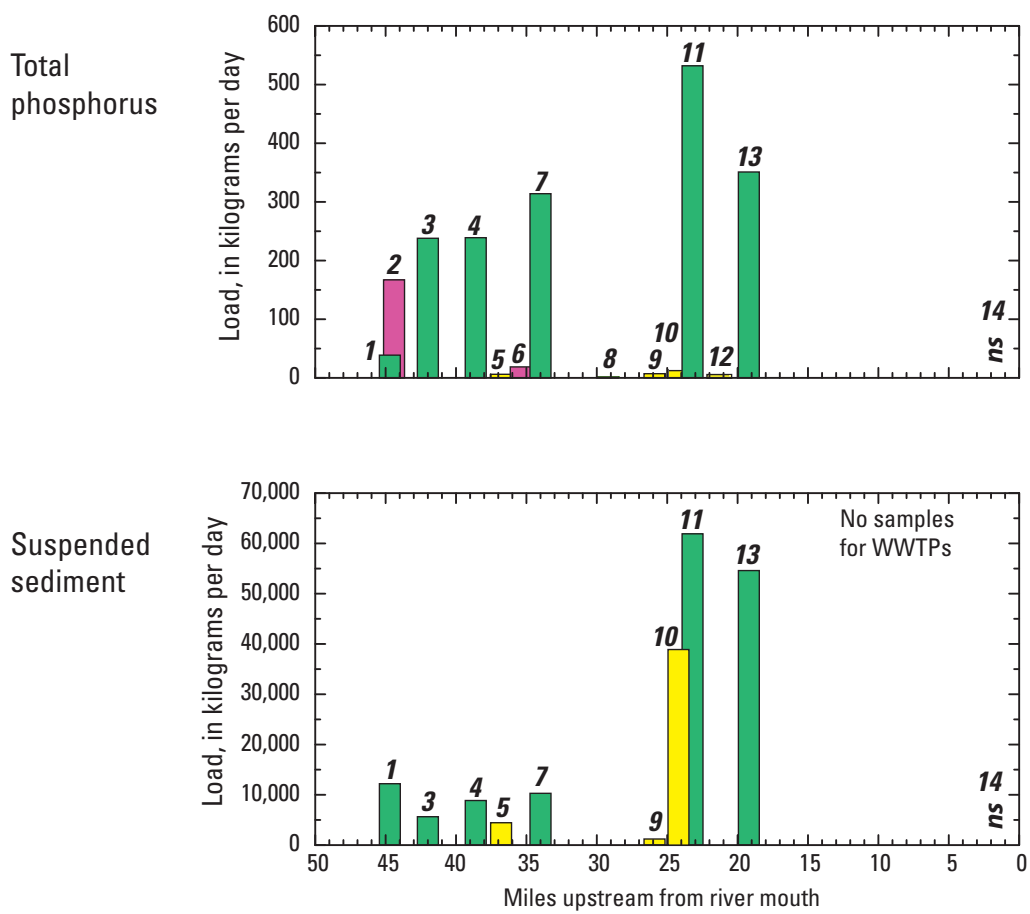

\section{EXPLANATION}

\section{Monitoring station type}

Mainstem

$\square$ Wastewater treatment plant (WWTP)

$\square$ Tributary

Monitoring station name (miles upstream from river mouth)

1 Blackstone River Millbury upstream (44.7 mi)

2 UBWPAD WWTP (44.4 mi)

3 Blackstone River Millbury downstream (42.0 mi)

4 Blackstone River Wilkinsonville (38.6 mi)

5 Quinsigamond River (36.8 mi)

6 Grafton WWTP (35.4 mi)

7 Blackstone River South Grafton (34.0 mi)

8 Northbridge WWTP (29.2 mi)

9 Mumford River (25.9 mi)

10 West River (24.2 mi)

11 Blackstone River Uxbridge (23.2 mi)

12 Uxbridge WWTP (21.3 mi)

13 Blackstone River Millville (19.2 mi)

14 Blackstone River Pawcatuck (2 mi)

ns no samples

Streamflow at Blackstone River Millville station

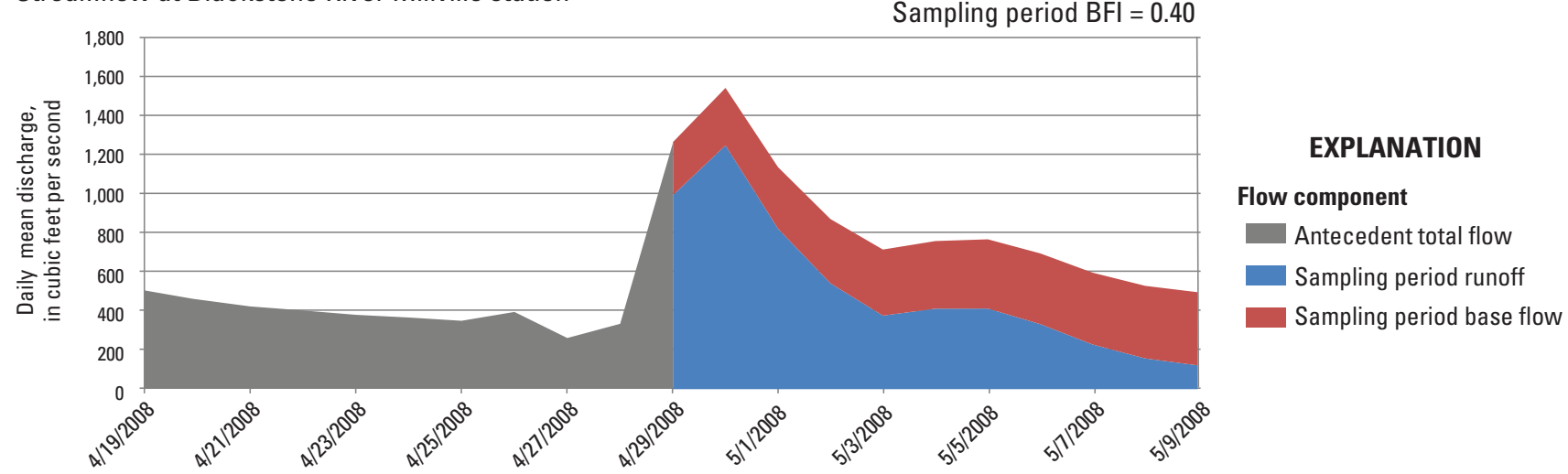

Figure 5. Loads of total nitrogen, total phosphorus, and suspended sediment at stream monitoring stations and wastewater treatment plants (WWTPs) from composite samples in the Blackstone River Basin, Massachusetts and Rhode Island, for the 2-week sampling periods starting A, August 28, 2007, B, April 28, 2008, C, June 24, 2008, D, September 16, 2008, E, May 13, 2009, F, July 7, 2009, and $G$, September 1, 2009. BFI, base-flow index (average during the sampling period); mi, miles; UBWPAD, Upper Blackstone Water Pollution Abatement District.-Continued 
C. Sampling period starting June 24,2008

Estimated constituent load

Total nitrogen

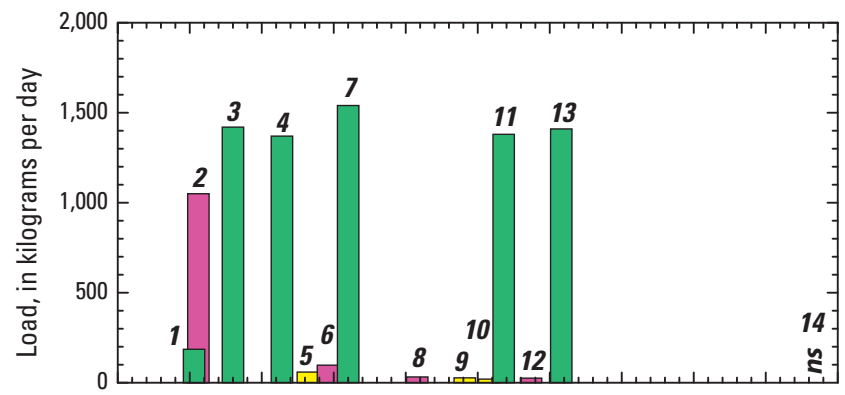

Total phosphorus

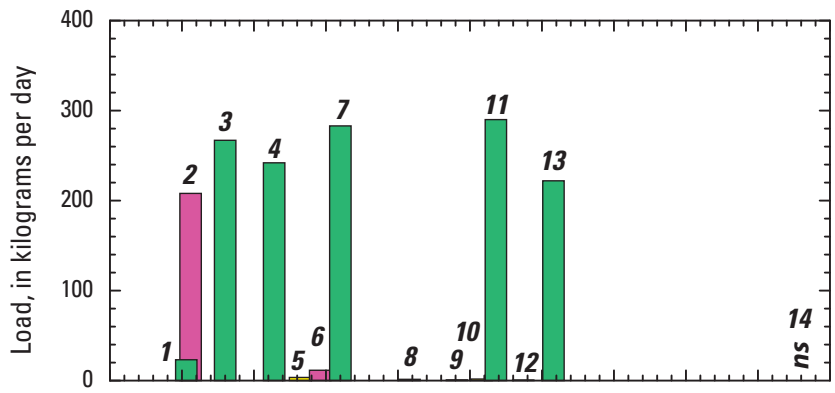

Suspended sediment

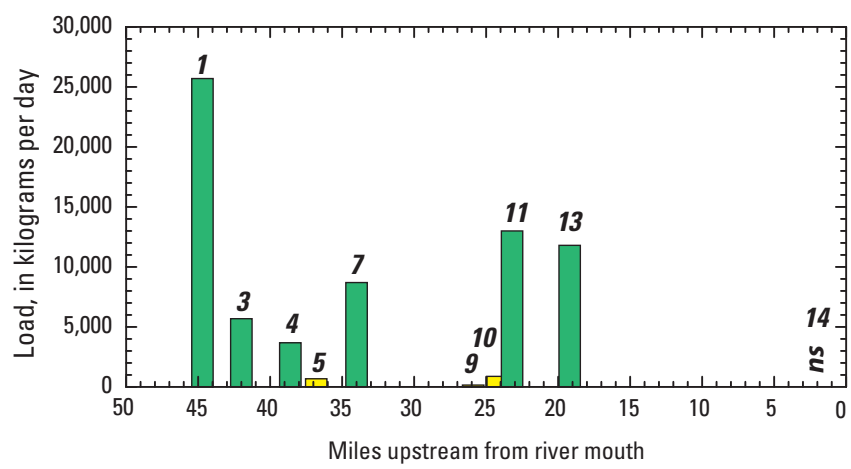

\section{EXPLANATION}

Monitoring station type

Mainstem

Wastewater treatment plant (WWTP)

Tributary

Monitoring station name (miles upstream from river mouth)

1 Blackstone River Millbury upstream (44.7 mi)

2 UBWPAD WWTP (44.4 mi)

3 Blackstone River Millbury downstream (42.0 mi)

4 Blackstone River Wilkinsonville (38.6 mi)

5 Quinsigamond River (36.8 mi)

6 Grafton WWTP (35.4 mi)

7 Blackstone River South Grafton (34.0 mi)

8 Northbridge WWTP (29.2 mi)

9 Mumford River (25.9 mi)

10 West River (24.2 mi)

11 Blackstone River Uxbridge (23.2 mi)

12 Uxbridge WWTP (21.3 mi)

13 Blackstone River Millville (19.2 mi)

14 Blackstone River Pawcatuck (2 mi)

ns no samples
Streamflow at Blackstone River Millville station

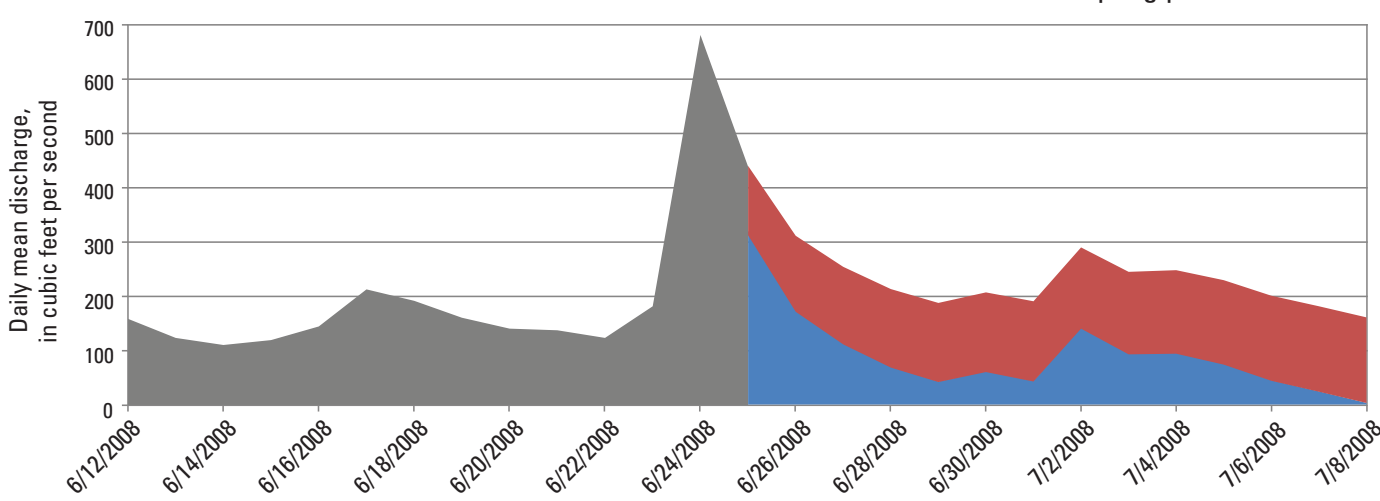

EXPLANATION

Flow component

Antecedent total flow

Sampling period runoff

Sampling period base flow

Figure 5. Loads of total nitrogen, total phosphorus, and suspended sediment at stream monitoring stations and wastewater treatment plants (WWTPs) from composite samples in the Blackstone River Basin, Massachusetts and Rhode Island, for the 2-week sampling periods starting $A$, August 28, 2007, B, April 28, 2008, C, June 24, 2008, D, September 16, 2008, E, May 13, 2009, F, July 7, 2009, and $G$, September 1, 2009. BFI, base-flow index (average during the sampling period); mi, miles; UBWPAD, Upper Blackstone Water Pollution Abatement District.-Continued 
D. Sampling period starting September 16, 2008

Estimated constituent load

Total nitrogen

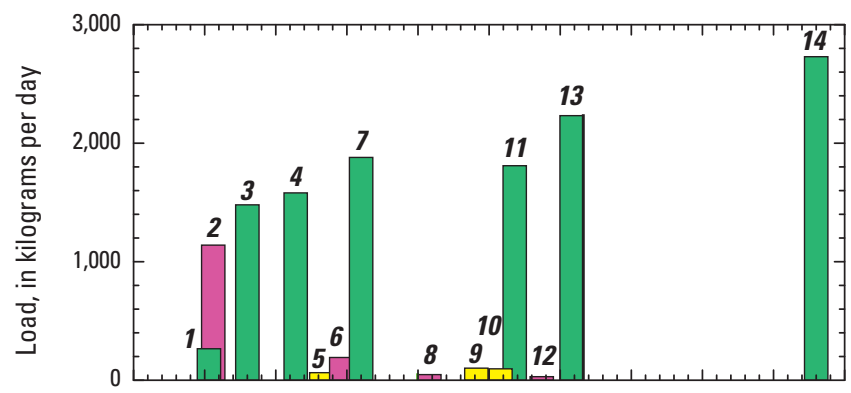

Total phosphorus

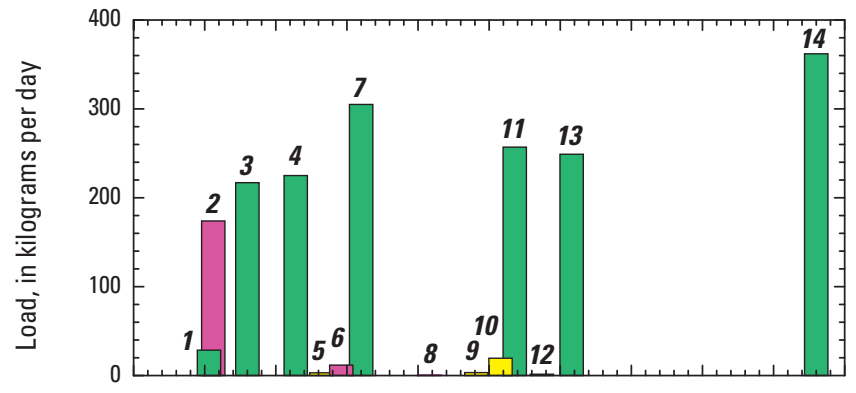

Suspended sediment

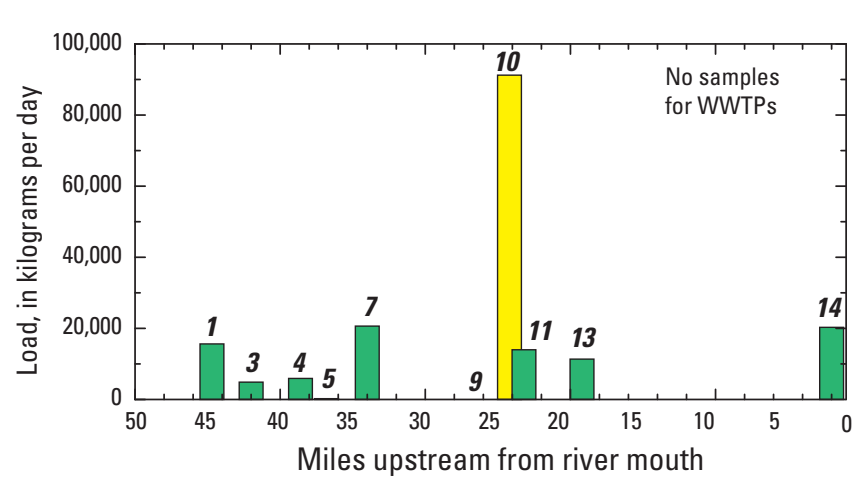

\section{EXPLANATION}

Monitoring station type

$\square$ Mainstem

Wastewater treatment plant (WWTP)

Tributary

Monitoring station name (miles upstream from river mouth)

1 Blackstone River Millbury upstream (44.7 mi)

2 UBWPAD WWTP (44.4 mi)

3 Blackstone River Millbury downstream (42.0 mi)

4 Blackstone River Wilkinsonville (38.6 mi)

5 Quinsigamond River (36.8 mi)

6 Grafton WWTP (35.4 mi)

7 Blackstone River South Grafton (34.0 mi)

8 Northbridge WWTP (29.2 mi)

9 Mumford River (25.9 mi)

10 West River (24.2 mi)

11 Blackstone River Uxbridge (23.2 mi)

12 Uxbridge WWTP (21.3 mi)

13 Blackstone River Millville (19.2 mi)

14 Blackstone River Pawcatuck (2 mi)

ns no samples
Streamflow at Blackstone River Millville station

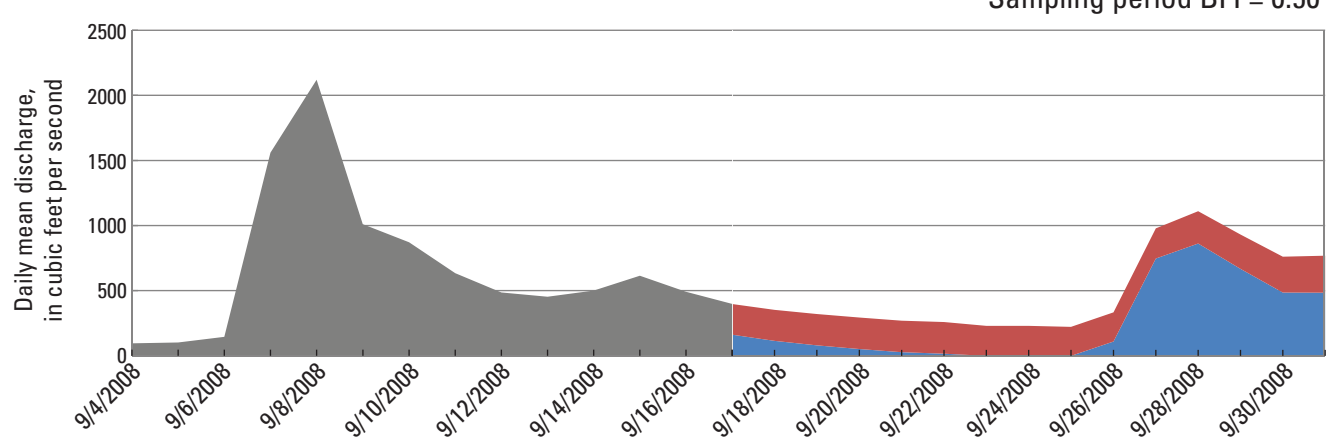

EXPLANATION

Flow component

Antecedent total flow

Sampling period runoff

Sampling period base flow

Figure 5. Loads of total nitrogen, total phosphorus, and suspended sediment at stream monitoring stations and wastewater treatment plants (WWTPs) from composite samples in the Blackstone River Basin, Massachusetts and Rhode Island, for the 2-week sampling periods starting $A$, August 28, 2007, B, April 28, 2008, C, June 24, 2008, D, September 16, 2008, E, May 13, 2009, F, July 7, 2009, and G, September 1, 2009. BFI, base-flow index (average during the sampling period); mi, miles; UBWPAD, Upper Blackstone Water Pollution Abatement District.—Continued 
Estimated constituent load

Total nitrogen

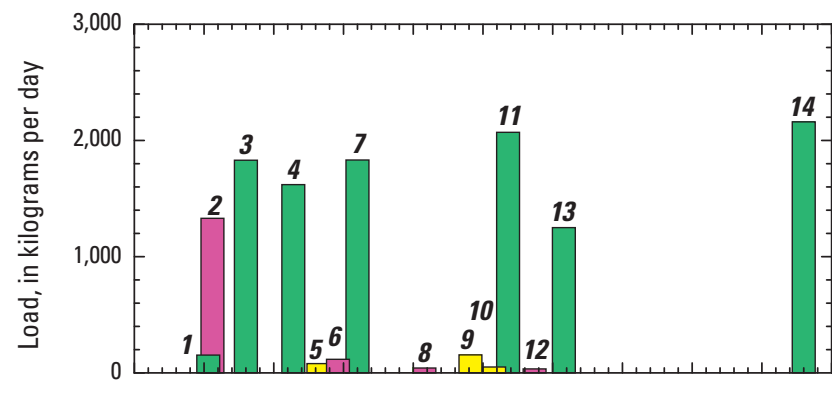

Total phosphorus

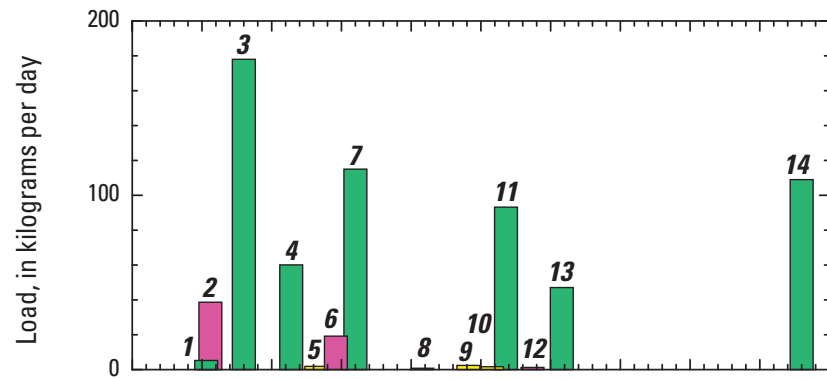

Suspended sediment

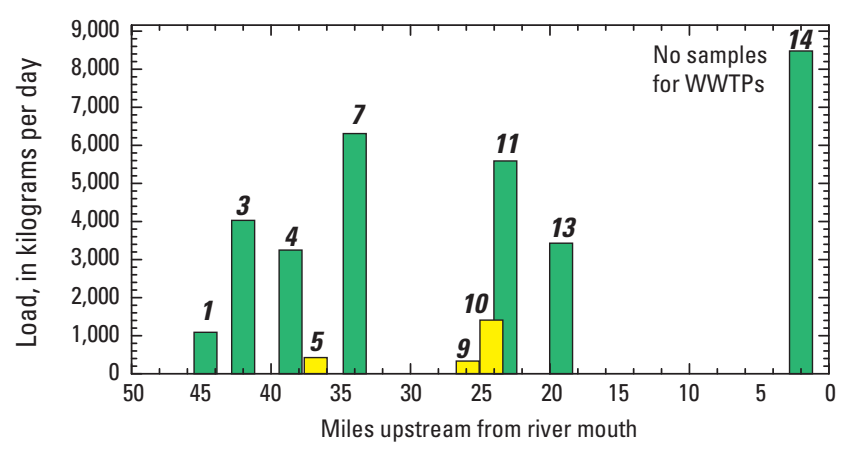

\section{EXPLANATION}

Monitoring station type

Mainstem

Wastewater treatment plant (WWTP)

Tributary

Monitoring station name (miles upstream from river mouth)

1 Blackstone River Millbury upstream (44.7 mi)

2 UBWPAD WWTP (44.4 mi)

3 Blackstone River Millbury downstream (42.0 mi)

4 Blackstone River Wilkinsonville (38.6 mi)

5 Quinsigamond River (36.8 mi)

6 Grafton WWTP (35.4 mi)

7 Blackstone River South Grafton (34.0 mi)

8 Northbridge WWTP (29.2 mi)

9 Mumford River (25.9 mi)

10 West River (24.2 mi)

11 Blackstone River Uxbridge (23.2 mi)

12 Uxbridge WWTP (21.3 mi)

13 Blackstone River Millville (19.2 mi)

14 Blackstone River Pawcatuck (2 mi)

ns no samples

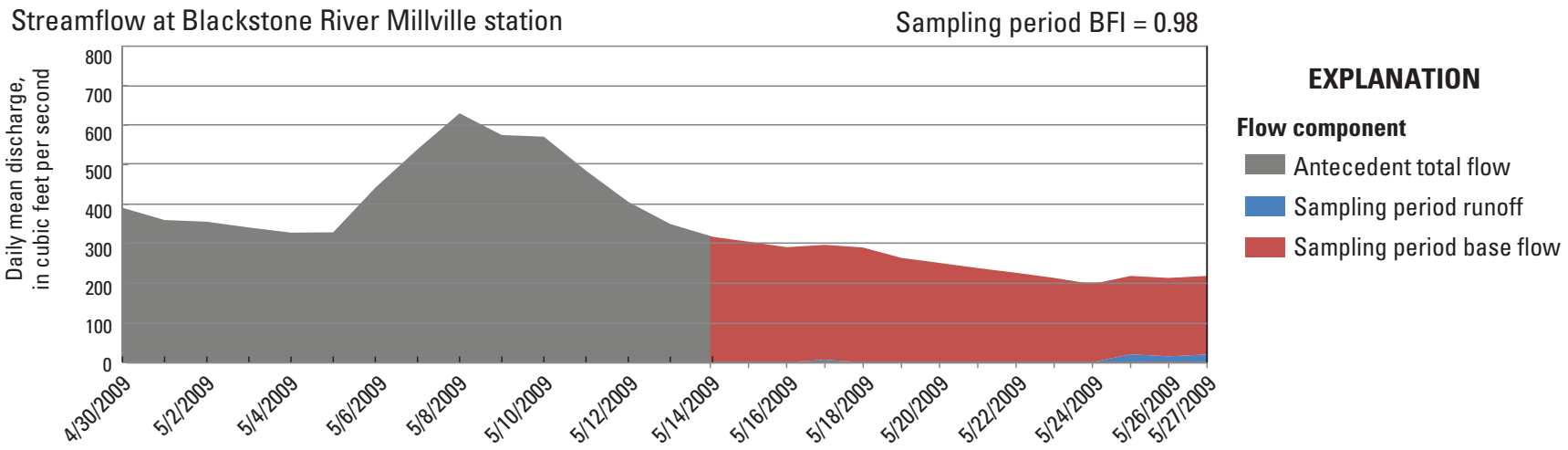

Figure 5. Loads of total nitrogen, total phosphorus, and suspended sediment at stream monitoring stations and wastewater treatment plants (WWTPs) from composite samples in the Blackstone River Basin, Massachusetts and Rhode Island, for the 2-week sampling periods starting A, August 28, 2007, B, April 28, 2008, C, June 24, 2008, D, September 16, 2008, E, May 13, 2009, F, July 7, 2009, and G, September 1, 2009. BFI, base-flow index (average during the sampling period); mi, miles; UBWPAD, Upper Blackstone Water Pollution Abatement District.-Continued 
F. Sampling period starting July 7, 2009

Estimated constituent load

Total nitrogen

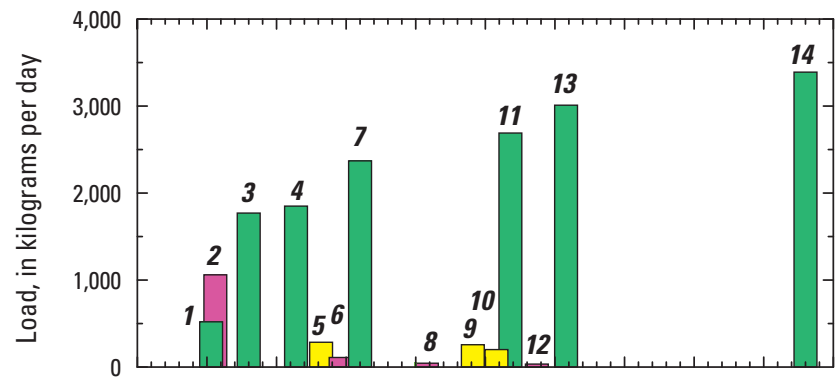

Total phosphorus
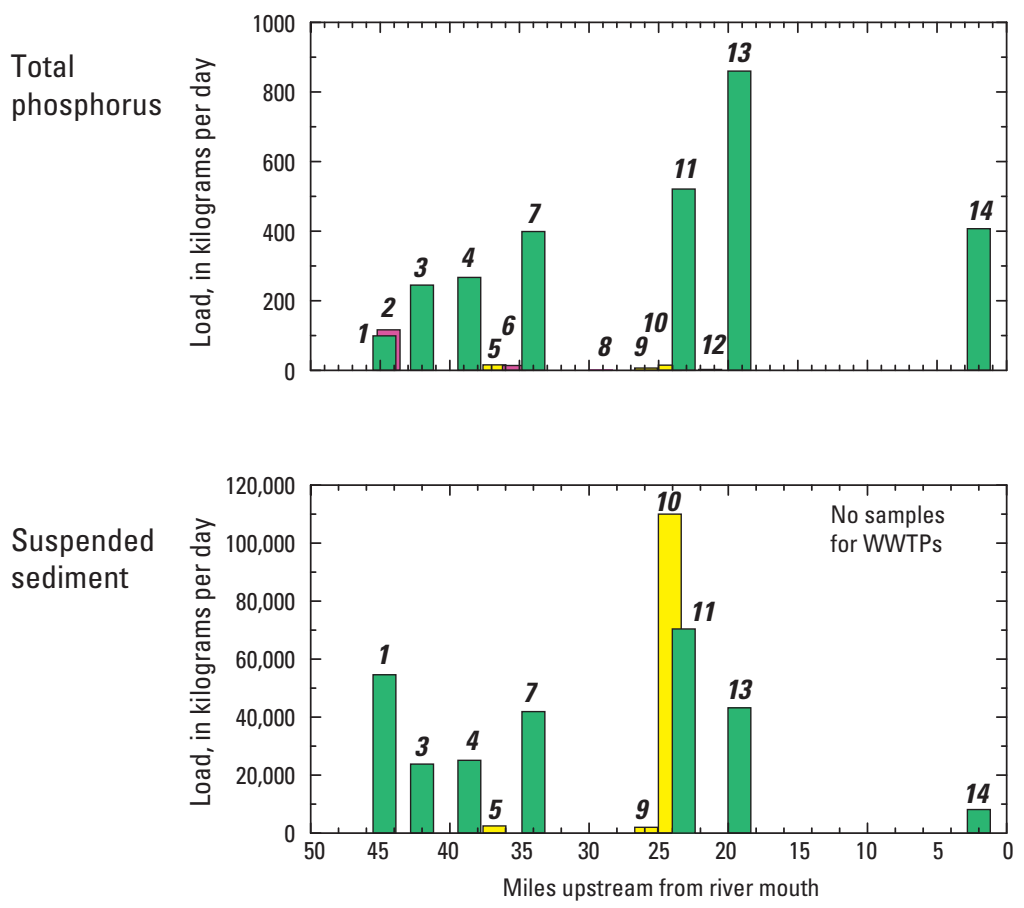

\section{EXPLANATION}

Monitoring station type

Mainstem

Wastewater treatment plant (WWTP)

Tributary

Monitoring station name (miles upstream from river mouth)

1 Blackstone River Millbury upstream (44.7 mi)

2 UBWPAD WWTP (44.4 mi)

3 Blackstone River Millbury downstream (42.0 mi)

4 Blackstone River Wilkinsonville (38.6 mi)

5 Quinsigamond River (36.8 mi)

6 Grafton WWTP (35.4 mi)

7 Blackstone River South Grafton (34.0 mi)

8 Northbridge WWTP (29.2 mi)

9 Mumford River (25.9 mi)

10 West River (24.2 mi)

11 Blackstone River Uxbridge (23.2 mi)

12 Uxbridge WWTP (21.3 mi)

13 Blackstone River Millville (19.2 mi)

14 Blackstone River Pawcatuck (2 mi)

$n \boldsymbol{s}$ no samples
Streamflow at Blackstone River Millville station

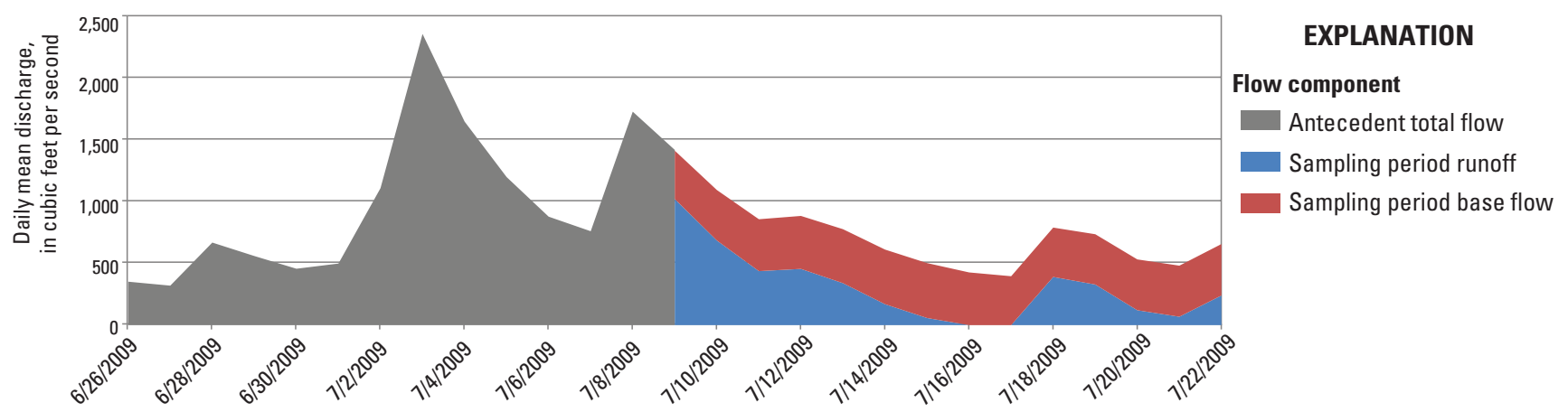

Figure 5. Loads of total nitrogen, total phosphorus, and suspended sediment at stream monitoring stations and wastewater treatment plants (WWTPs) from composite samples in the Blackstone River Basin, Massachusetts and Rhode Island, for the 2-week sampling periods starting $A$, August 28, 2007, B, April 28, 2008, C, June 24, 2008, D, September 16, 2008, E, May 13, 2009, F, July 7, 2009, and $G$, September 1, 2009. BFI, base-flow index (average during the sampling period); mi, miles; UBWPAD, Upper Blackstone Water Pollution Abatement District.-Continued 
Estimated constituent load

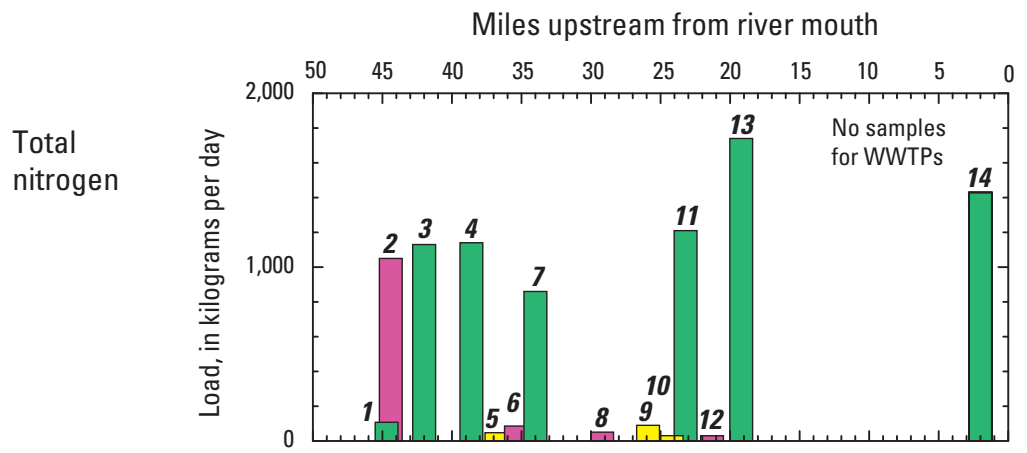

\section{EXPLANATION}

Monitoring station type

$\square$ Mainstem

$\square$ Wastewater treatment plant (WWTP)

$\square$ Tributary

Monitoring station name (miles upstream from river mouth)

1 Blackstone River Millbury upstream (44.7 mi)

2 UBWPAD WWTP (44.4 mi)

3 Blackstone River Millbury downstream (42.0 mi)

4 Blackstone River Wilkinsonville (38.6 mi)

5 Quinsigamond River (36.8 mi)

6 Grafton WWTP (35.4 mi)

7 Blackstone River South Grafton (34.0 mi)

Total

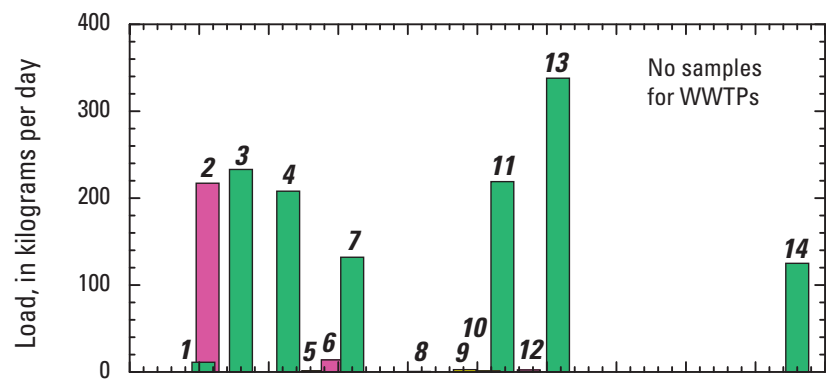

8 Northbridge WWTP (29.2 mi)

9 Mumford River (25.9 mi)

10 West River (24.2 mi)

11 Blackstone River Uxbridge (23.2 mi)

12 Uxbridge WWTP (21.3 mi)

13 Blackstone River Millville (19.2 mi)

14 Blackstone River Pawcatuck (2 mi)

ns no samples
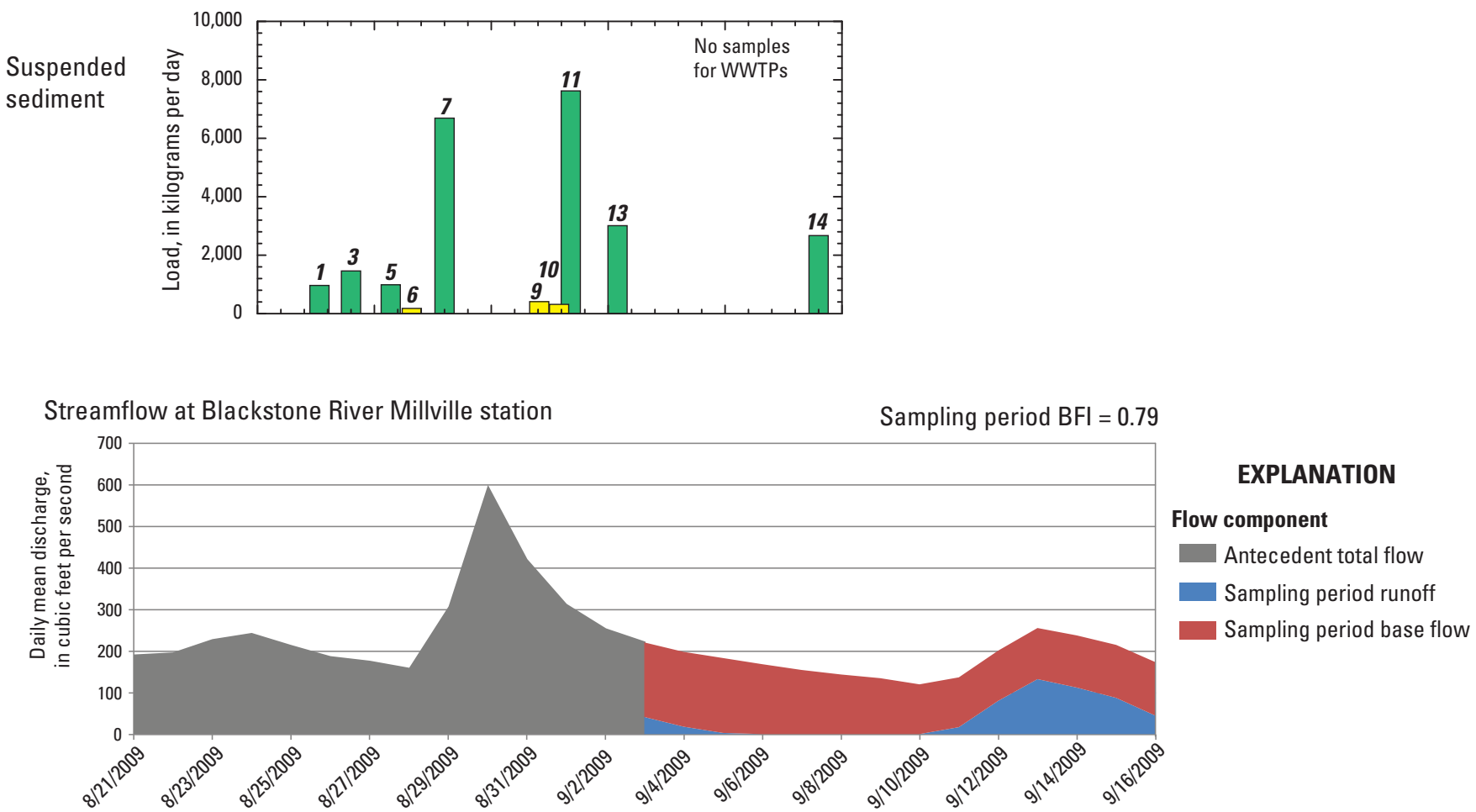

Figure 5. Loads of total nitrogen, total phosphorus, and suspended sediment at stream monitoring stations and wastewater treatment plants (WWTPs) from composite samples in the Blackstone River Basin, Massachusetts and Rhode Island, for the 2-week sampling periods starting A, August 28, 2007, B, April 28, 2008, C, June 24, 2008, D, September 16, 2008, E, May 13, 2009, F, July 7, 2009, and $G$, September 1, 2009. BFI, base-flow index (average during the sampling period); mi, miles; UBWPAD, Upper Blackstone Water Pollution Abatement District.-Continued 


\section{Nutrient, Suspended Sediment, and Trace Element Loads in the Blackstone River Basin in Mass. and R.I., 2007 to 2009}

The loads described in this report are primarily for monitoring stations in the Massachusetts segment of the basin. The farthest upstream station in Millbury (Blackstone River Millbury upstream station, 01109659) is upstream of the location where effluent from the UBWPAD wastewater treatment plant is discharged and is just downstream of the Worcester-Millbury town border. The farthest downstream station in Massachusetts (Blackstone River Millville station, 01111230) is about 1.3 mi upstream from the MassachusettsRhode Island border.

One of the major objectives of this study was to estimate loads of total nitrogen, total phosphorus, suspended sediment, and trace elements leaving Massachusetts and entering Rhode Island via the Blackstone River. To meet this objective, sampling at the Blackstone River Millville station extended year round from June 2007 through September 2009. These data were used to estimate total annual loads of constituents leaving Massachusetts during water years 2008 and 2009.

Total nitrogen loads are partly based on concentrations of total dissolved nitrogen for part or all of some sampling periods at some stations. This approach was used to address discrepancies between analytical results for total nitrogen and total dissolved nitrogen in many of the composite samples. The approach likely underestimates the total nitrogen loads calculated on the basis of these samples. However, use of these estimates is not expected to greatly affect study findings because they are most frequently used for samples from tributaries and at the Blackstone River Millbury upstream station (where loads are relatively small compared with main stem loads) and samples that represent relatively small fractions of total streamflow during the sampling period (see the "Methods" section for a more detailed discussion).

\section{Nitrogen}

\section{Total Nitrogen Loads}

Total nitrogen loads along the Blackstone River in Massachusetts showed a similar general pattern during all sampling periods monitored in this study: relatively low total nitrogen loads at the farthest upstream monitoring station (Blackstone River Millbury upstream station, 01109659), a 5- to 10-fold increase in total nitrogen load downstream of the UBWPAD, and total nitrogen loads that remained elevated but varied from Millbury to the MassachusettsRhode Island border near Millville (fig. 5; table 3, at back of report). The tributaries and wastewater treatment plants other than the UBWPAD rarely constituted more than a small fraction of the total nitrogen loads observed at the main stem monitoring stations.

Total nitrogen loads at the Blackstone River Millbury upstream station (01109659), given as daily mean loads, were typically less than 430 kilograms per day $(\mathrm{kg} / \mathrm{d})$, with a median value of $170 \mathrm{~kg} / \mathrm{d}$ (tables 3 , at back of report, and 4). At the next station downstream (Blackstone River Millbury downstream station, 01109730), total nitrogen loads were typically 1,000 to $2,000 \mathrm{~kg} / \mathrm{d}$, with a median value $1,450 \mathrm{~kg} / \mathrm{d}$. This large increase reflected nitrogen inputs from the UBWPAD, which were typically 950 to $1,200 \mathrm{~kg} / \mathrm{d}$ with a median value of $1,100 \mathrm{~kg} / \mathrm{d}$. Nitrogen loads contributed by the three monitored tributaries to the main stem Blackstone River were much smaller, with median values of $77 \mathrm{~kg} / \mathrm{d}$ for the Mumford River, $66 \mathrm{~kg} / \mathrm{d}$ for the Quinsigamond River, and $49 \mathrm{~kg} / \mathrm{d}$ for the West River. Similarly, nitrogen inputs from the Grafton, Northbridge, and Uxbridge wastewater treatment plants were relatively small, with median values of 124,44 , and $31 \mathrm{~kg} / \mathrm{d}$, respectively.

At all monitoring stations along the Blackstone River downstream of the UBWPAD, total nitrogen loads were typically about 1,000 to $3,000 \mathrm{~kg} / \mathrm{d}$ (tables 3 , at back of report, and 4). There was no overall consistent spatial pattern in loads in the Blackstone River downstream of the UBWPAD. Overall decreases in total nitrogen load (fig. $5 A$, period starting August 28, 2007), increases in total nitrogen load (figs. $5 B, D$, and $F$; periods starting April 28, 2008, September 16, 2008, and July 7, 2009, respectively) or stable or variable trends (figs. 5C, $E$, and $G$; periods starting June 24, 2008, May 13, 2009, and September 1, 2009, respectively) were observed along the river from the Blackstone River Millbury downstream station (01109730) to the Blackstone River Millville station (01111230). Consistent patterns also were not observed between adjacent main stem monitoring stations, except for a relatively consistent small increase in total nitrogen load between the Blackstone River Wilkinsonville (01109852) and Blackstone River South Grafton (01110400) stations after May 2008 (fig. 5C-F; appendix 6). The Grafton wastewater treatment plant discharge and the Quinsigamond River enter the river in this reach (fig. 2).

\section{Nitrogen Loads and Hydrologic Conditions}

Total nitrogen loads in the Blackstone River, between the UBWPAD and the Massachusetts-Rhode Island border varied considerably in magnitude among the various sampling periods. Differences were largely due to differences in hydrologic conditions. Evaluation of the distribution and magnitudes of estimated daily mean total nitrogen loads indicated that the following hydrologic factors during sampling periods were important: (1) the relative contributions of runoff and base flow to total streamflow and (2) antecedent streamflow conditions. The distribution of streamflow from runoff and base flow may be related to loads because of the different possible sources of nitrogen in the watershed. Antecedent streamflow conditions may be related to loads in several ways. For example, a storm that generates runoff that occurs in an upstream reach of the Blackstone River Basin a few days from the start of sampling may transport a nutrient or trace element load downstream where the storm flows may no longer be apparent. Particulate fractions of the total load may settle along the river bottom only to be resuspended by a subsequent change of stream velocity associated with new runoff. Therefore, base 


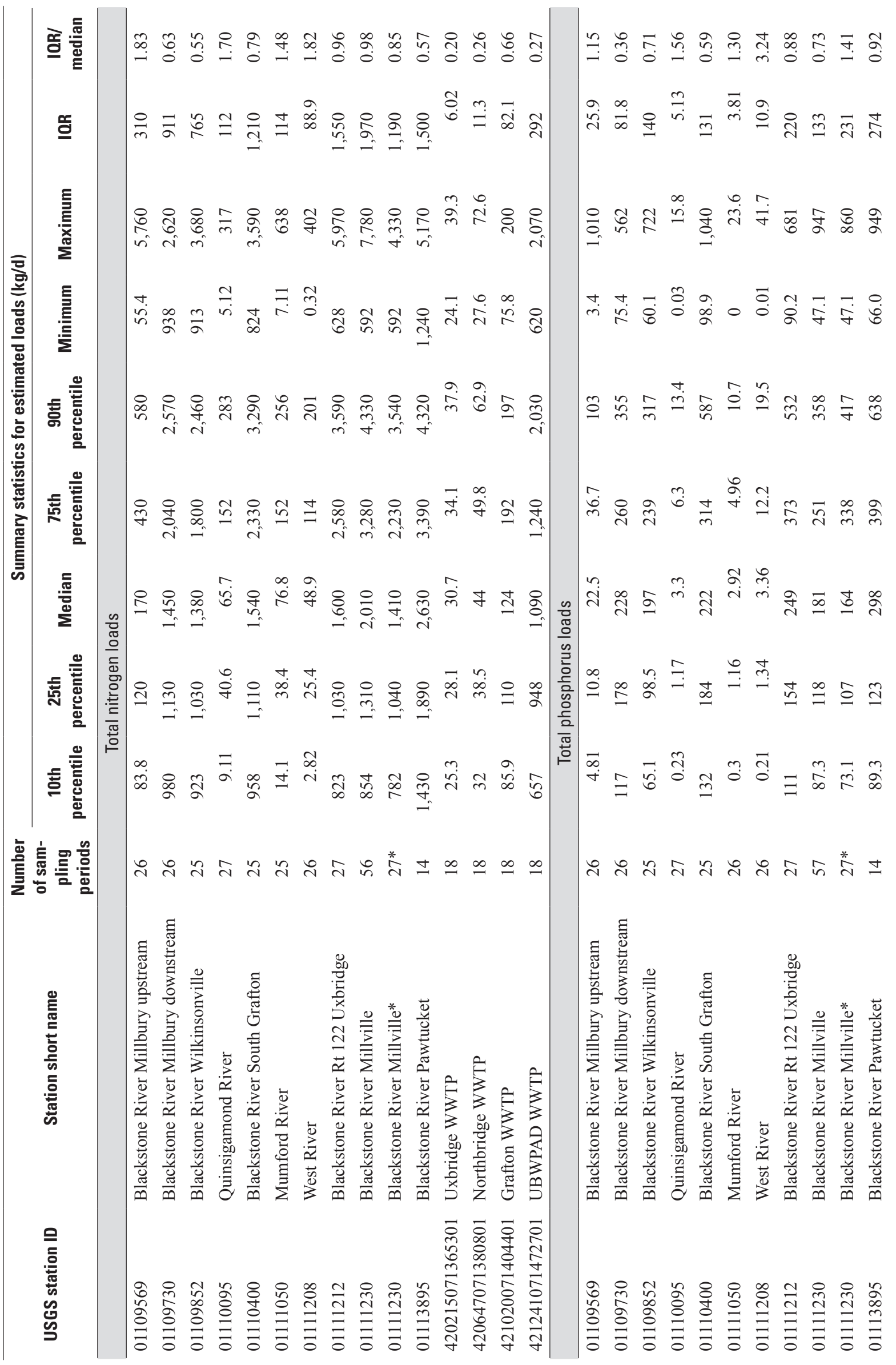




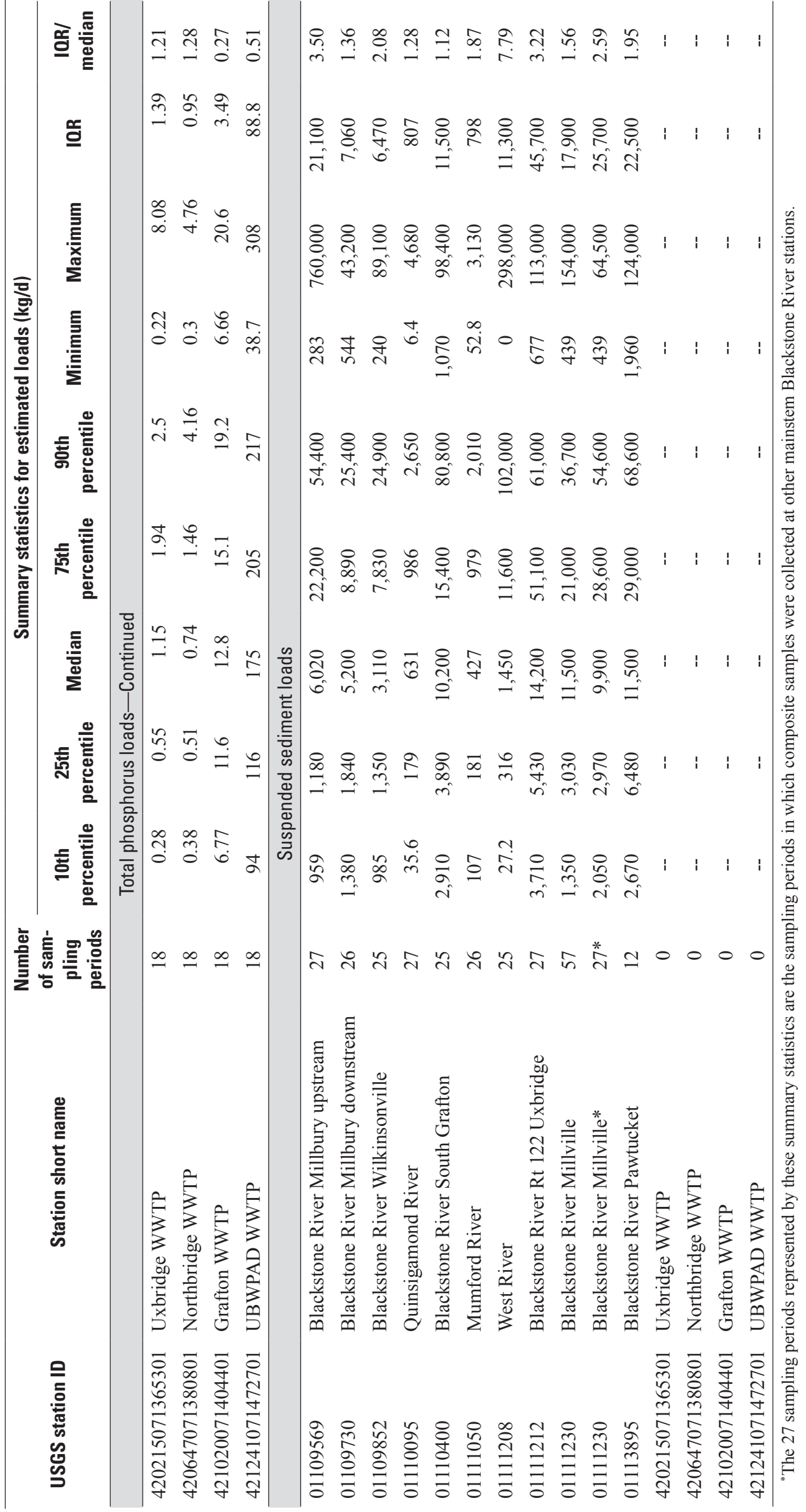


flows during sampling periods and the antecedent hydrologic conditions were examined for the study detailed in this report in relation to the distribution of nitrogen constituent loads throughout the Blackstone River Basin to better understand the observed patterns of nitrogen loads at monitoring stations.

In order to simplify interpretation, streamflow in the Blackstone River at the Millville station (01111230) based on measured flow at the Blackstone River Uxbridge station (01111212) was used to represent these factors for the entire basin. Hydrographs of antecedent conditions and the fractions of total streamflow during the sampling period from base flow and from runoff (Lim and others, 2005) were based on daily mean discharge at the Blackstone River Millville station. The fraction of total streamflow from base flow is measured by the BFI. In this report, the BFI for sampling periods ranged from 0.25 to 0.99 (appendix 6). Under natural conditions, base flow in a river is predominantly flow that originates from groundwater discharge. However, in a river that receives effluent from wastewater treatment plants, flow in the river during base-flow conditions also includes wastewater treatment plant discharge and in fact may be dominated by wastewater treatment plant discharges during low flows (Barbaro and Zarriello, 2007).

Extremely large daily total nitrogen loads (three or more stations with total nitrogen loads larger than $3,000 \mathrm{~kg} / \mathrm{d}$ ) in the Massachusetts segment of the Blackstone River were estimated for the sampling periods starting March 24, April 28, September 2, 2008, and July 21, 2009 (fig. 5; table 3, at back of report; appendix 6). The BFI values for these periods were $0.79,0.40,0.25$, and 0.41 , respectively, indicating that the base-flow component of stream flow was relatively small (for three of the four) and large proportions of the flow in the river originated as storm runoff. Examination of the associated hydrographs shows that all these periods experienced elevated stream flows (flows about $500 \mathrm{ft}^{3} / \mathrm{s}$ or larger). Although the March 24, 2008, sampling period had a relatively high BFI, indicating low runoff during the period, it also had an antecedent high discharge period. These sampling periods also had high total nitrogen loads from the UBWPAD-2,000 kg/d for the March and April 2008 sampling periods, about twice the median value (wastewater treatment plant loads were not measured for the September 2, 2008, and July 21, 2009, sampling periods). Thus, the general pattern of large increases in main stem river loads downstream of the UBWPAD was maintained during these high-flow periods. However, the high streamflows also were associated with additional increases in estimated loads further downstream that were probably attributable to nonpoint source runoff and resuspension and transport of nitrogenous material in the river.

During sampling periods when estimated total nitrogen loads were low (most stations with total nitrogen loads of about $1,000 \mathrm{~kg} / \mathrm{d}$ or less), the BFI was relatively high, ranging from 0.74 to 0.99 . These included sampling periods starting June 26, 2007, July 23, 2007, August 28, 2007, September 24, 2007, July 8, 2008, August 19, 2008, and September 15, 2009 (fig. 5; table 3, at back of report; appendix 6). Total nitrogen loads at the UBWPAD also were relatively low during these sampling periods (less than or equal to the 25th percentile in four of the five sampling periods in which wastewater treatment plant loads were measured). These periods of low nitrogen loads and high BFI values were characterized by low total streamflow (less than $250 \mathrm{ft}^{3} / \mathrm{s}$ at the Blackstone River Millville station).

Some of the differences in total nitrogen loads between upstream and downstream monitoring stations along the Blackstone River in a sampling period resulted from the timing of streamflow changes within and before the sampling period. Substantial increases in streamflow before or early in the sampling period were associated with increases in nitrogen loads at downstream monitoring stations. This occurred during sampling periods starting on March 24, 2008, April 28, 2008, July 22, 2008, August 5, 2008, July 7, 2009, and July 21, 2009 (figs. $5 A$ and $F$; appendix 6 ).

A scatter plot of total nitrogen loads and BFI for the Blackstone River Millville monitoring station for all sampling periods shows an inverse relation between total nitrogen loads and BFI values (fig. $6 A$ ). Thus, total nitrogen loads were lower when base flow (nonstorm flow) constituted a larger fraction of total streamflow, and total nitrogen loads were higher when runoff constituted a larger fraction of streamflow. When base flow was more than 60 percent of total flow (BFI larger than 0.6 ), total nitrogen loads were typically less than $1,000 \mathrm{~kg} / \mathrm{d}$; at lower values of BFI, total nitrogen loads were more variable, ranging between about 2,000 to $4,000 \mathrm{~kg} / \mathrm{d}$. The higher total nitrogen loads during periods of higher runoff resulted in part from high loads from the UBWPAD during these periods, as mentioned earlier in this section, but also likely resulted from higher contributions of total nitrogen from sources in the watershed that were delivered to the river during runoff events. There is one outlier value for which nitrogen load is high and BFI also is high (BFI equal to 0.79 , total nitrogen load equal to $4,300 \mathrm{~kg} / \mathrm{d}$ ). The starting date of the sampling period associated with the outlier value was March 24, 2008; the antecedent conditions included a runoff event that is typically associated with high total nitrogen loads in the downstream reaches of the river (see discussion earlier in this section).

An analysis of total wastewater treatment plant loads as a percentage of total nitrogen loads in the river at the Blackstone River Millville station (fig. $6 B$ ) provides additional information about the possible sources of the nitrogen loads. There are fewer data for this analysis than for the comparison of total nitrogen loads and BFI (fig. $6 A$ ) because wastewater treatment plant loads were not measured as frequently as were the loads at the Millville station. Total wastewater treatment plant loads as a percentage of total nitrogen loads increase with increasing BFI. Thus, wastewater treatment plant loads represent the greatest fraction of total nitrogen loads in the river when most of the flow in the river is base flow and there is little contribution of flow from storm runoff. Although the highest total nitrogen loads were during periods of higher runoff, the proportion of river flows that originated as wastewater was higher during periods of lower runoff as could be expected in a river 
A.

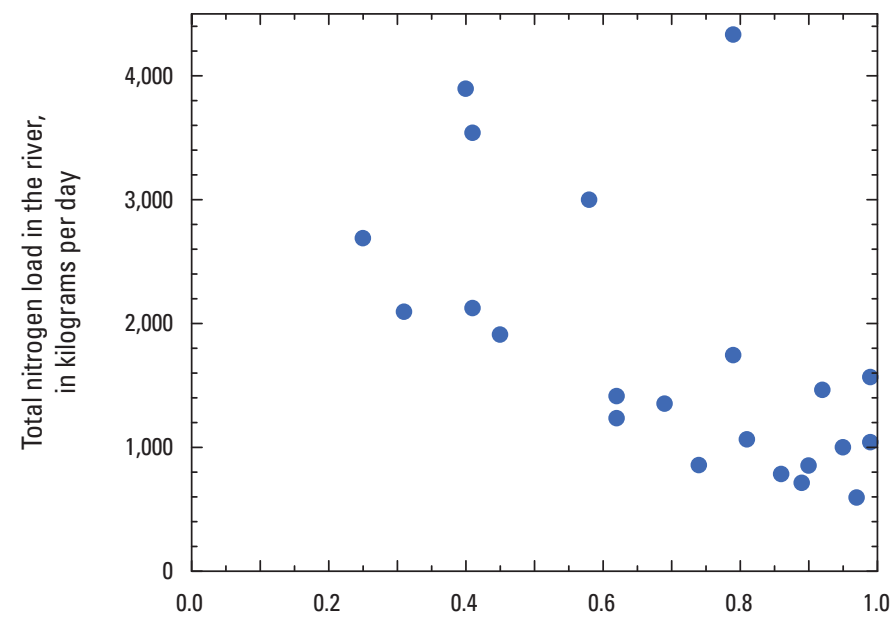

B.

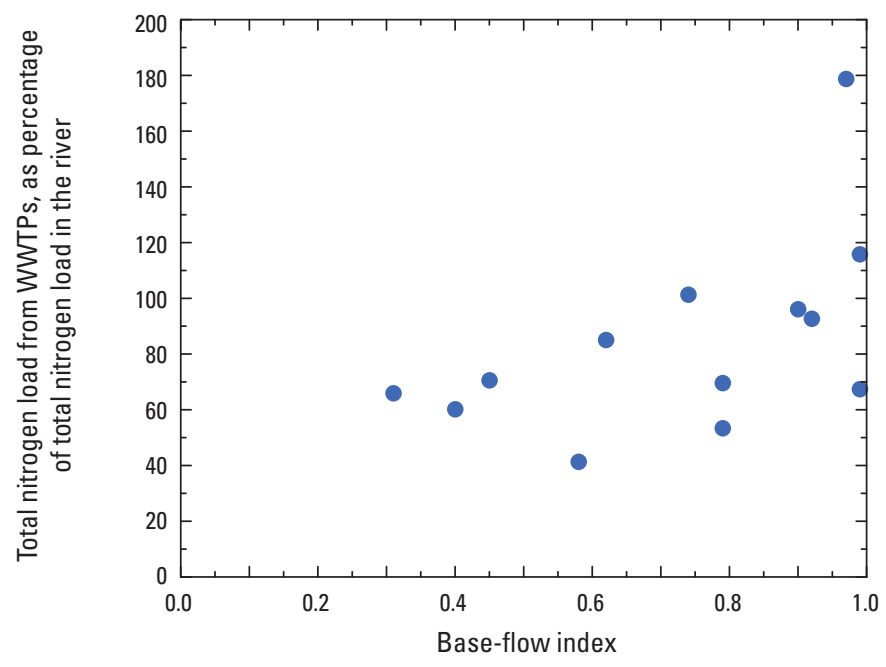

Figure 6. Comparison of total nitrogen loads and base-flow index at the stream monitoring station at the Blackstone River at Millville, Massachusetts (01111230), from 2007 to 2009, for

$A$, total nitrogen load and $B$, total nitrogen load from wastewater treatment plants as percentage of total nitrogen load in the river. WWTP, wastewater treatment plant.

that receives a substantial input of wastewater discharge. The data (fig. 6) also suggest that sources other than wastewater are important during periods of high runoff; during sampling periods when runoff was 40 percent or more of total flow (BFI less than or equal to 0.6 ), wastewater treatment plant loads accounted for no more than about 70 percent of the total nitrogen load at the Blackstone River Millville station. The outlier on this graph (BFI equal to 0.97 , total wastewater treatment plant load equal to 179 percent of total load at the Blackstone River Millville station) represents the sampling period starting August 28, 2007 (fig. 5A), in which streamflow was very low and total nitrogen loads decreased substantially downstream along the main stem of the river; nitrogen attenuation may have occurred during this sampling period.
Nitrogen Attenuation

A mass-balance approach was used to investigate nitrogen attenuation in the Blackstone River. Nitrogen loads entering and leaving each monitored main stem reach were compared to determine whether loads decreased within the reach and to investigate the relative importance of the reach with respect to attenuation. The following five reaches (figs. 1 and 2) were investigated for each sampling period: (1) Millbury upstream to Millbury downstream (01109659 to 01109730; $2.7 \mathrm{mi}$ ), (2) Millbury downstream to Wilkinsonville (01109730 to 01109852; $3.4 \mathrm{mi}$ ), (3) Wilkinsonville to South Grafton (01109852 to $01110400 ; 4.6 \mathrm{mi})$, (4) South Grafton to Uxbridge (01110400 to $01111212 ; 10.8 \mathrm{mi})$, and (5) Uxbridge to Millville ( 01111212 to $01111230 ; 4.0 \mathrm{mi})$. There were no attenuation data for the reach upstream from the Millbury upstream station because there was no monitoring upstream of that station. Sampling periods for which there are no data on loads from the wastewater treatment plants are not included in this analysis. In water year 2007, there are two sampling periods with full sets of data; in water year 2008, there were seven; and in water year 2009, there were five.

Nitrogen loads entering a reach consisted of the nitrogen load in the main stem river at the upstream end of the reach, nitrogen loads from monitored tributaries and wastewater treatment plants that discharged to the river within the reach, and nitrogen loads from unmonitored areas of the watershed that drained to the river along the reach. Nitrogen loads leaving the reach consisted of the nitrogen load at the main stem monitoring station at the downstream end of the reach. Consequently, the change in nitrogen load along the reach was calculated as follows:

$$
\begin{gathered}
\text { Change }= \\
\operatorname{Tot}_{N_{u s}}-\left(\operatorname{Tot} N_{d s}+\operatorname{Tot} N_{\text {trib }}+\right. \\
\left.\operatorname{Tot} N_{\text {WWTP }}+\operatorname{Tot} N_{\text {unmonit }}\right),
\end{gathered}
$$

where

$$
\begin{aligned}
& \operatorname{TotN}_{u s} \quad \text { is the total nitrogen load at the monitoring } \\
& \text { station at the upstream end of the reach; } \\
& \operatorname{TotN}_{d s} \quad \text { is the total nitrogen load at the monitoring } \\
& \text { station at the downstream end of the reach; } \\
& \operatorname{TotN}_{\text {trib }} \quad \text { is the total nitrogen load at monitored } \\
& \text { tributaries along the reach; } \\
& \text { Tot } N_{\text {WWTP }} \text { is the total nitrogen load at wastewater } \\
& \text { treatment plants along the reach; and } \\
& \operatorname{Tot}_{\text {unmonit }} \quad \text { is the total nitrogen load estimated for } \\
& \text { unmonitored areas that drain to the river } \\
& \text { along the reach. }
\end{aligned}
$$

Net losses or gains along reaches were indicated by negative or positive values, respectively. The change calculated in this way indicates losses or gains in the nitrogen load carried by the river after changes due to additional point and nonpoint source inputs are taken into account. Thus, nitrogen attenuation was indicated for sampling periods and reaches for which the net change was negative (table 5). 


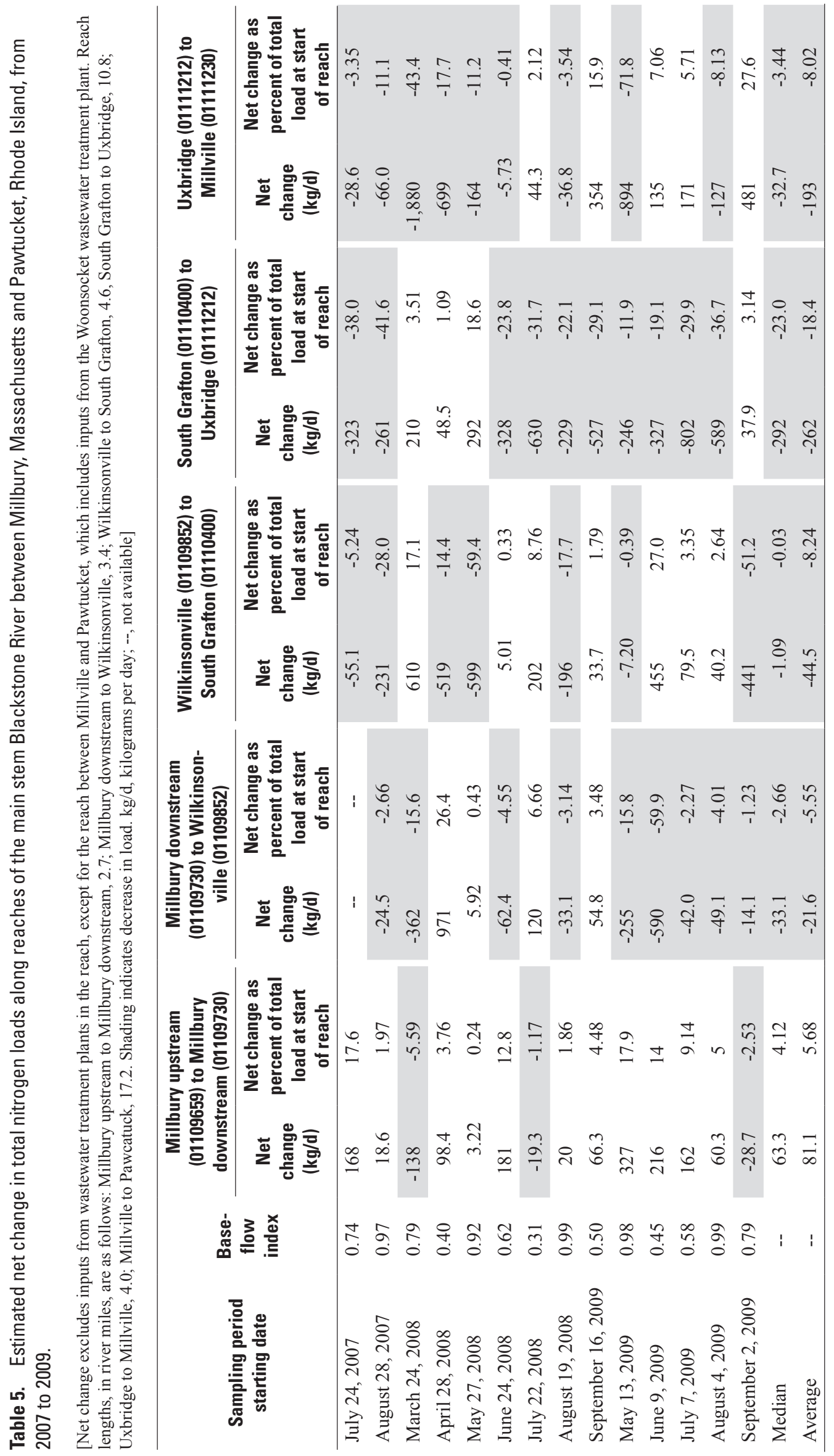


The comparisons of loads entering and leaving reaches included estimates of nitrogen inputs from unmonitored areas along the reach. These unmonitored areas consisted of the small watershed areas that drain to the major tributaries downstream of tributary monitoring stations (which for logistical reasons were at short distances upstream of the confluences of tributaries and the Blackstone River) and the small areas of the watershed that drain directly to the river between monitored tributaries. Nitrogen loads from these small unmonitored areas were estimated using the nitrogen load in the three monitored tributaries - the Quinsigamond, Mumford, and West Rivers. The drainages of these tributaries account for 27 percent of the area of the Blackstone River Basin. The land-use-area characteristics for the tributaries are quite similar to the characteristics of the entire basin. To use the data from these tributaries, the daily mean total nitrogen load from the three major tributaries for each sampling period was applied to each unmonitored contributing area on a per unit area basis. This was done by relating the unmonitored area above each station to the combined area of the three major tributaries. For example, if the unmonitored area was 10 percent of the area of the three monitored tributaries, then the nonpoint-source load in that area would be 10 percent of the sum of the load from the monitored tributaries. This was done to estimate loads from unmonitored areas for each sampling period.

Although loads from unmonitored areas were included, they accounted for very small fractions of the total loads in stream reaches for stations in the Massachusetts segment of the basin in most (75 percent) sampling periods, as follows: less than 1 percent at the Blackstone River Millbury downstream monitoring station (01109730), less than 4 percent at the Blackstone River Wilkinsonville station (01109852), less than 2 percent at the Blackstone River South Grafton station (01110400), less than 12 percent at the Blackstone River Uxbridge station (01111212), and less than 3 percent at the Blackstone River Millville station (01111230).

For the two sampling periods with sufficient monitoring data in 2007, net decreases in total nitrogen loads were observed (table 5) in all reaches except the reach between Millbury upstream and Millbury downstream monitoring stations (01109659 to 01109730). Both of those periods were marked by low to moderate storm runoff and moderate to high BFI values (appendix 6). These data suggest that, under low-flow conditions, nitrogen loads may be attenuated in the downstream reaches.

In 2008, the net changes in total nitrogen loads at in the reaches between the Millbury upstream and Millbury downstream stations (01109659 to 01109730) and the Millbury downstream and the Wilkinsonville stations (01109730 to 01109852) were not large and most often represented increases. The net change in loads in the reaches between the Wilkinsonville and South Grafton stations (01109852 to 01110400), South Grafton and Uxbridge stations (01110400 to 01111212), and Uxbridge to Millville stations (01111212 to 01111230) included both increases and decreases.
In 2009 , the variability in net changes among the loads at the monitoring stations was not substantially different from the variability in 2008. However, net losses were always observed in the reach between the Millbury downstream and Wilkinsonville stations (01109730 to 01109852) and, in all but one sampling period, in the reach between the South Grafton and Uxbridge stations (01110400 to 01111212). Net losses between the South Grafton and Uxbridge stations in 2009, as well as in 2007 and 2008, were consistently about 20 percent or larger.

Examination of the median and average net changes in total nitrogen loads between consecutive monitoring stations moving downstream serves to synthesize the results (table 5). In the farthest upstream reach (Millbury upstream to Millbury downstream stations, $2.7 \mathrm{mi}$ ), there was little indication of nitrogen attenuation, as small net increases in total load were observed. Farther downstream, nitrogen attenuation may have occurred during some of the sampling periods, especially in the 10.6-mi reach between the South Grafton and Uxbridge stations. Total nitrogen loads at the downstream end of this reach were substantially lower than nitrogen load inputs to the reach in most sampling periods, with median and average decreases of total nitrogen loads of about 20 percent (table 5). Decreases in total nitrogen loads in the reaches between the Millbury downstream and Wilkinsonville stations (3.4 mi), Wilkinsonville and South Grafton stations (4.6 mi), and Uxbridge and Millville stations (4.0 mi) were less, averaging 5 to 10 percent.

The analysis suggests that attenuation of the nitrogen load in the river may have occurred in parts of the Blackstone River in the Massachusetts segment of the basin during some of the sampling periods. Results were variable, however. Also, because the total nitrogen loads data are limited to sampling periods when all monitoring stations were active, the specific results may not be applicable throughout the year (for example, during the winter months) or during different hydrologic conditions.

\section{Phosphorus}

Total phosphorus loads along the Blackstone River showed the same general pattern as nitrogen loads, but overall were lower and more variable than nitrogen loads. Generally, total phosphorus loads were relatively low at the farthest upstream monitoring station (Blackstone River Millbury upstream station, 01109659), increased 6- to 15-fold downstream of the UBWPAD, and then were relatively high but variable from the Blackstone River Millbury downstream station to the Massachusetts-Rhode Island border near the Blackstone River Millville station (fig. 5; table 3, at back of report). As with nitrogen, contributions of total phosphorus load from the tributaries and wastewater treatment plants (other than UBWPAD) were only small fraction of the loads observed at the main stem river monitoring stations.

Total phosphorus loads at the Blackstone River Millbury upstream station were typically less than about $37 \mathrm{~kg} / \mathrm{d}$, with 
a median value of $22.5 \mathrm{~kg} / \mathrm{d}$ (tables 3, at back of report, and 4). At the next station downstream (Blackstone Millbury downstream station, 01109730), total phosphorus loads were typically 178 to $260 \mathrm{~kg} / \mathrm{d}$, with a median value of $228 \mathrm{~kg} / \mathrm{d}$, reflecting the relatively large inputs from the UBWPAD. Total phosphorus loads discharged from the UBWPAD changed during the study period, however. Total phosphorus loads at the UBWPAD were mostly near $200 \mathrm{~kg} / \mathrm{d}$ in 2007 and 2008 (figs. 5A-E; tables 3, at back of report, and 5). In 2009, however, the loads decreased substantially to near $100 \mathrm{~kg} / \mathrm{d}$ (fig. $5 F$; tables 3, at back of report, and 5), except for the total phosphorus load during the September 2, 2009, sampling period that slightly exceeded $200 \mathrm{~kg} / \mathrm{d}$ (fig. $5 G$ ). The decrease in phosphorus loads probably reflected the implementation of new effluent limits for the UBWPAD that became effective on October 1, 2008, under the U.S. Environmental Protection Agency's National Pollutant Discharge Elimination System (U.S. Environmental Protection Agency, 2014).

Total phosphorus loads at monitoring stations along the Blackstone River downstream of the UBWPAD typically were about 100 to $370 \mathrm{~kg} / \mathrm{d}$ (tables 3 , at back of report, and 4). Loads varied among monitoring stations, but there were some consistent patterns. In 2008 and 2009, total phosphorus loads at almost all the Blackstone River monitoring stations downstream of the UBWPAD were larger than the loads in UBWPAD discharge (table 4); the reverse trend was observed in 2007. Total phosphorus loads at the Blackstone River South Grafton monitoring station were almost always larger than loads at the Blackstone River Wilkinsonville station $4.6 \mathrm{mi}$ upstream (figs. $5 B-F$; table 3 , at back of report); a consistent increase was also observed in total nitrogen load in this reach, which includes inputs from the Grafton wastewater treatment plant and the Quinsigamond River. Finally, total phosphorus loads at the Blackstone River Millville monitoring station were almost always less than loads at the Blackstone River Uxbridge monitoring station, $4.0 \mathrm{mi}$ upstream (figs. $5 A-F$; table 3, at back of report) and the Blackstone River South Grafton monitoring station, 14.8 mi upstream, suggesting a net loss of phosphorus load upstream of the Blackstone River Millville monitoring station. Total phosphorus loads usually increased between the Blackstone River Millville station, near the Massachusetts-Rhode Island border, and the Blackstone River Pawtucket monitoring station near the river's mouth in Rhode Island, which were measured from September 2008 through September 2009 (figs. $5 F-G$; table 3, at back of report).

\section{Suspended Sediment}

Suspended sediment was not measured in wastewater treatment plant effluents; hence, loads of suspended sediment data are described only for tributary and main stem monitoring stations (fig. 5; table 3, at back of report). The suspended sediment loads determined for main stem monitoring stations generally were substantially larger than those determined for the tributaries; tributary loads rarely exceeded $1,000 \mathrm{~kg} / \mathrm{d}$, whereas median loads of suspended sediment at main stem stations ranged from $3,110 \mathrm{~kg} / \mathrm{d}$ to more than $10,000 \mathrm{~kg} / \mathrm{d}$ (table 3, at back of report). Sampling periods with very small loads of suspended sediment in the tributaries were noted during sampling periods starting June 26, July 24, August 28, and September 24, 2007, and September 1 and 15, 2009 (fig. $5 F$; table 3 , at back of report).

There were several sampling periods during which large loads of suspended sediment entered the study area from upstream of the Blackstone River Millbury upstream monitoring station (the drainage area of the highly urbanized city of Worcester) and from the three tributaries. During the sampling period starting September 2, 2008 (table 3, at back of report), the load upstream from the UBWPAD was about $760,000 \mathrm{~kg} / \mathrm{d}$, substantially more than the loads determined elsewhere along the river's main stem; Hurricane Hannah, which struck the region during this sampling period, generated the runoff transporting the suspended sediment load from the metropolitan Worcester area. The sampling period starting July 21,2009 , was also marked by an extremely large-stormgenerated suspended sediment load of about $200,000 \mathrm{~kg} / \mathrm{d}$ entering at the upstream boundary of the study area.

During some sampling periods (those starting April 28, August 5, and September 2 and 16, 2008, and July 9 and 23, and August 4, 2009), the loads entering the Blackstone River from the West River were very large, especially in comparison to the loads carried in the main stem (fig. $5 F$; table 3 , at back of report). The U.S. Army Corps of Engineers operates the flood-control West Hill Dam on the West River in Uxbridge. Under normal meteorological conditions, West Hill Dam does not retain (impound) much water. When rainfall is heavy, dam operators hold back potential flood waters until the waters can be released safely. These releases may carry substantial amounts of suspended sediment that was previously retained in the dam's impoundment.

There was considerable variability in the relative suspended sediment loads at the Blackstone River monitoring stations at Millville, nearby Uxbridge (4.0 mi upstream from Millville), and Pawtucket. Changing hydrological conditions that may resuspend sediments and the timing of releases from West Hill Dam are probably the primary causes of the observed differences. Over a wide range of loads, loads at Millville were almost always less than or equal to the loads at Uxbridge; exceptions occurred during the October 22, 2007, and the June 9 and 23, 2009, sampling periods (table 3, at back of report).

\section{Annual Loads of Nitrogen, Phosphorus, and Suspended Sediment at Millville, Massachusetts}

The estimated annual load of total nitrogen in the Blackstone River at the Millville monitoring station, about 1.3 mi upstream from the Massachusetts-Rhode Island border, was $936,000 \mathrm{~kg}(2,600 \mathrm{~kg} / \mathrm{d})$ in water year 2008 and was somewhat lower at $878,000 \mathrm{~kg}(2,400 \mathrm{~kg} / \mathrm{d})$ in water year 
2009 (table 6). The estimated annual load of total nitrogen $(936,000 \mathrm{~kg})$ was about 4 percent lower than the estimated annual load of total dissolved nitrogen $(973,000 \mathrm{~kg})$ in water year 2008; the estimated load of total nitrogen may have been biased toward a low value because of errors in total nitrogen concentrations that were not entirely corrected by the procedure of using dissolved nitrogen loads in place of total nitrogen loads for sampling periods in which total nitrogen concentrations exceeded total dissolved nitrogen concentrations by more than 10 percent (see the "Methods" section for detailed discussion). The estimated annual load of total phosphorus in the Blackstone River at the Millville station was $81,400 \mathrm{~kg}$ in water year $2008(223 \mathrm{~kg} / \mathrm{d})$ and only slightly less at $80,900 \mathrm{~kg}(222 \mathrm{~kg} / \mathrm{d})$ in water year 2009 . In contrast, the estimated annual load of suspended sediment in water year $2009(7,040,000 \mathrm{~kg}$ or 19,300 kg/d) was about 40 percent larger in water year 2009 than in water year 2008 $(4,940,000 \mathrm{~kg}$ or $13,600 \mathrm{~kg} / \mathrm{d})$. The higher load of suspended sediment in water year 2009 likely reflects the larger flows in 2009 compared with those in 2008 (see "Comparisons of Nutrient, Suspended Sediment, and Trace Element Loads at Millville and Pawtucket" section) and several large storms in water year 2009.

Table 6. Estimated total annual loads of nutrients, suspended sediment, and selected trace elements in the Blackstone River at Millville, Massachusetts, in water years 2008 and 2009.

[--, not available]

\begin{tabular}{lcc}
\hline \multirow{2}{*}{ Constituent } & \multicolumn{2}{c}{ Annual load } \\
\cline { 2 - 3 } \multicolumn{1}{c}{ Nutrients and suspended sediment, in kilograms } \\
\hline Total phosphorus & 81,400 & 80,900 \\
Dissolved phosphorus & 47,000 & 32,000 \\
Total nitrogen & 936,000 & 878,000 \\
Dissolved nitrogen & 973,000 & 804,000 \\
Suspended sediment & $4,940,000$ & $7,040,000$ \\
\hline & Trace elements, in kilograms & \\
\hline Total cadmium & 259 & -- \\
Dissolved cadmium & 177 & -- \\
Total chromium & 1,250 & -- \\
Dissolved chromium & 256 & -- \\
Total copper & 3,760 & -- \\
Dissolved copper & 2,100 & -- \\
Total lead & 1,670 & -- \\
Dissolved lead & 251 & -- \\
Total nickel & 1,510 & -- \\
Dissolved nickel & 1,150 & - \\
Total zinc & 11,900 & - \\
Dissolved zinc & 9,800 & - \\
\hline
\end{tabular}

Annual mean streamflows in the Blackstone River Basin during water years 2008 and 2009 were similar, though slightly higher in 2009 than in 2008. Annual mean flow at the Blackstone River Uxbridge station was $541 \mathrm{ft}^{3} / \mathrm{s}$ in 2008 and $618 \mathrm{ft}^{3} / \mathrm{s}$ in 2009. Annual mean flow at the long-term streamflow gaging station on Blackstone River in Woonsocket (01112500) was $841 \mathrm{ft}^{3} / \mathrm{s}$ in 2008 and $989 \mathrm{ft}^{3} / \mathrm{s}$ in 2009; the long-term (1929-2012) mean annual flow at the Woonsocket streamflow gaging station is $793 \mathrm{ft}^{3} / \mathrm{s}$. Thus, streamflow in water year 2009 was only about 18 percent larger than streamflow in water year 2008, and streamflow during the period of the study presented in this report (water years 2008 and 2009, during which most of the data on loads were collected) was on average only about 15 percent larger than long-term average flows. This suggests that loads of constituents from sources that are related to runoff and streamflow (such as nonpoint sources in the watershed and resuspension) likely represent typical current hydrologic conditions in the basin. Loads of constituents from point sources such as wastewater treatment facilities may vary independently of precipitation-driven flow.

\section{Comparisons of Nutrient, Suspended Sediment, and Trace Element Loads at Millville, Massachusetts, and Pawtucket, Rhode Island}

Loads of total nitrogen, total phosphorus, and suspended sediment at the Blackstone River Millville and Blackstone River Pawtucket monitoring stations are compared for parts of water years 2008 and 2009 in figure 7. Loads of selected trace elements at the two stations, which were measured at the Blackstone River Pawtucket station for a short time only, are compared in figure 8 for the latter part of water year 2008 and are listed in table 7. The time periods shown in figure 8 and listed in table 7 represent the entire time during which sampling was conducted at the Blackstone River Pawtucket monitoring station.

Total nitrogen and total phosphorus loads at the Blackstone River Pawtucket monitoring station were almost always larger than total nitrogen and total phosphorus loads upstream at the Millville monitoring station (figs. $5 D-F$ and $7 A-B$; table 3 , at back of report). Suspended sediment loads at the Pawtucket station, though usually less than loads at the Millville station, showed similar patterns of relatively high and low values (fig. 7C). The largest loads of total nitrogen, total phosphorus, and suspended sediment at both the Millville and Pawtucket stations generally coincided with periods of high streamflow, especially during two high flow events during summer 2009. The largest loads at the Pawtucket station were observed during the 2-week sampling period from July 22, 2009, to August 6, 2009. Streamflows in the Blackstone River during this period, as well as during a period at the beginning of July 2009, were as high as 10 times the mean month July flows in the river (based on long-term data at the Woonsocket station, 01112500). The 2-week total mass, not estimated daily mean loads, of total nitrogen at Pawtucket was $77,000 \mathrm{~kg}$; 

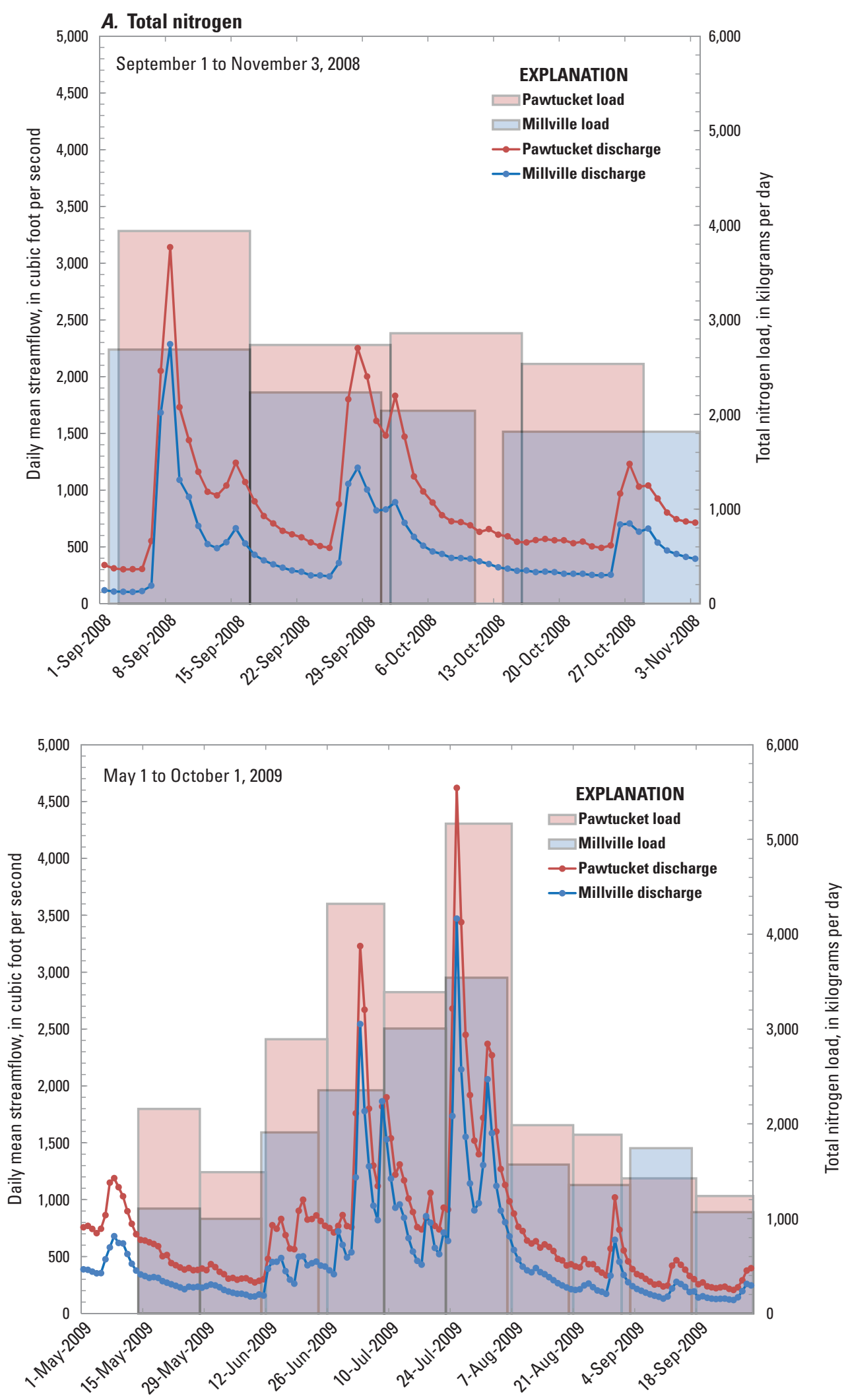

Figure 7. Loads of $A$, total nitrogen, $B$, total phosphorus, and $C$, suspended sediment and streamflow in the Blackstone River at monitoring stations in Millville, Massachusetts (01111230), and Pawtucket, Rhode Island (01113895), for September 1 to November 3, 2008, and May 1 to October 1, 2009. 

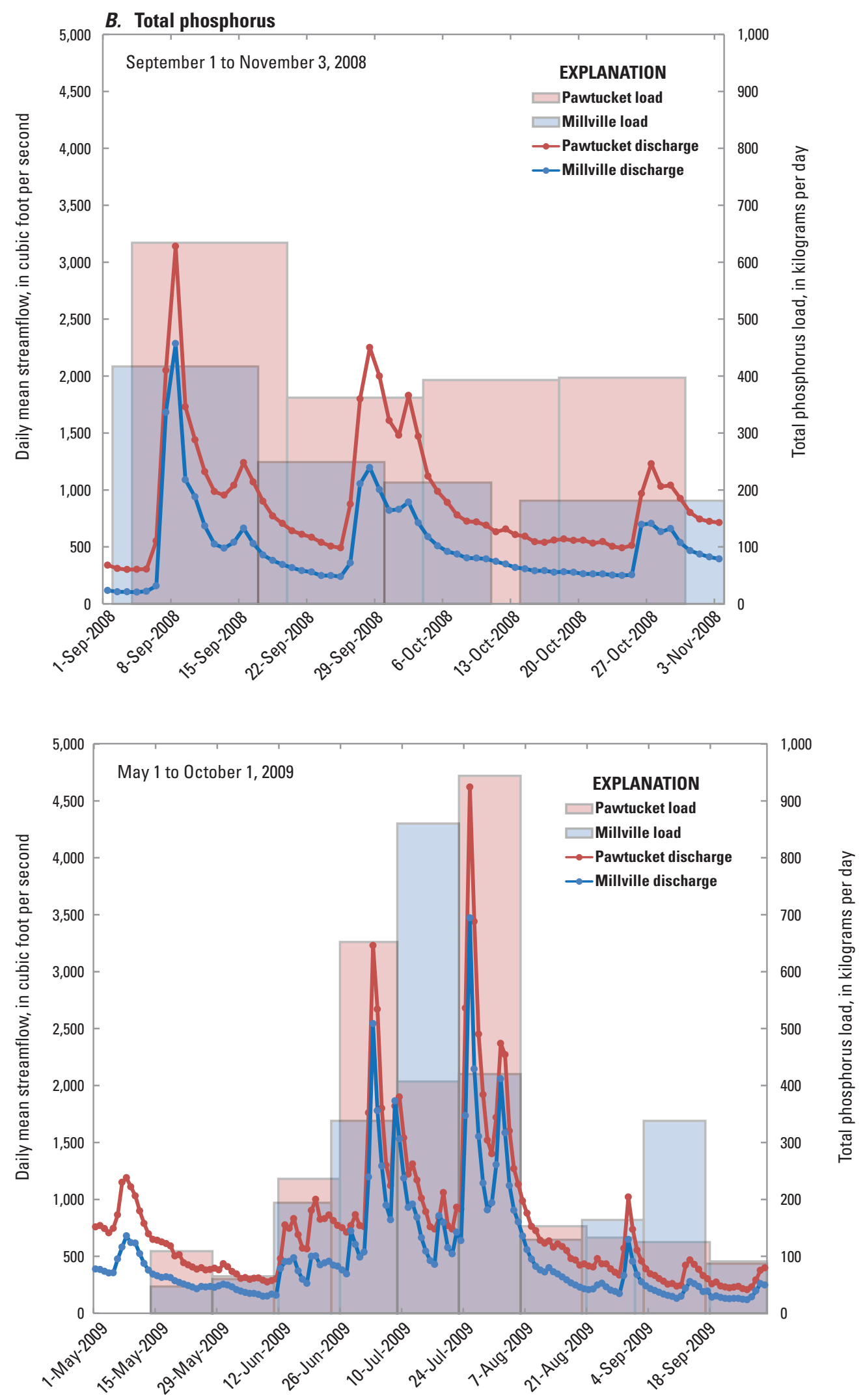

Figure 7. Loads of $A$, total nitrogen, $B$, total phosphorus, and $C$, suspended sediment and streamflow in the Blackstone River at monitoring stations in Millville, Massachusetts (01111230), and Pawtucket, Rhode Island (01113895), for September 1 to November 3, 2008, and May 1 to October 1 , 2009.-Continued 
C. Suspended sediment
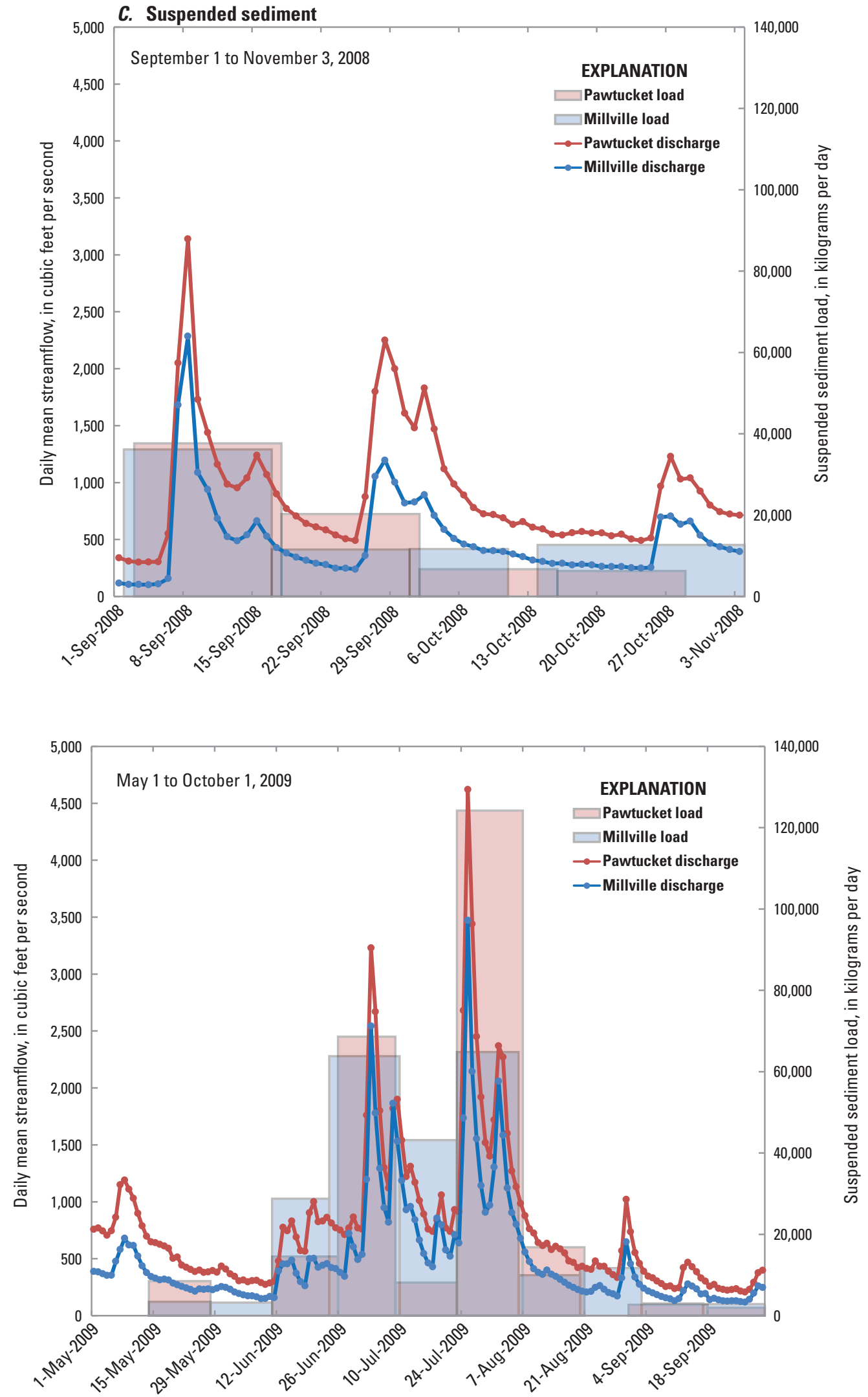

Figure 7. Loads of $A$, total nitrogen, $B$, total phosphorus, and $C$, suspended sediment and streamflow in the Blackstone River at monitoring stations in Millville, Massachusetts (01111230), and Pawtucket, Rhode Island (01113895), for September 1 to November 3, 2008, and May 1 to October 1, 2009.—Continued 


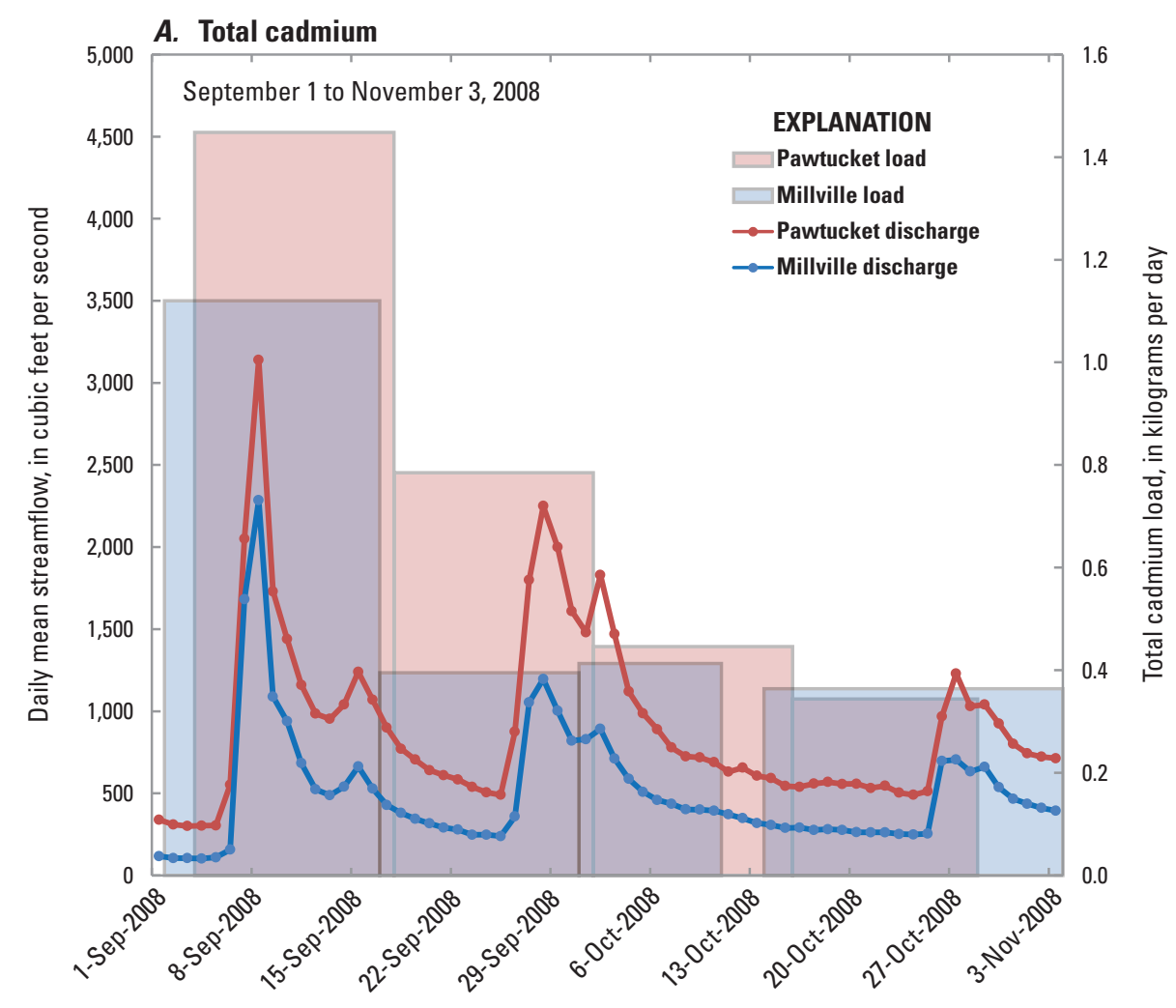

\section{B. Total chromium}

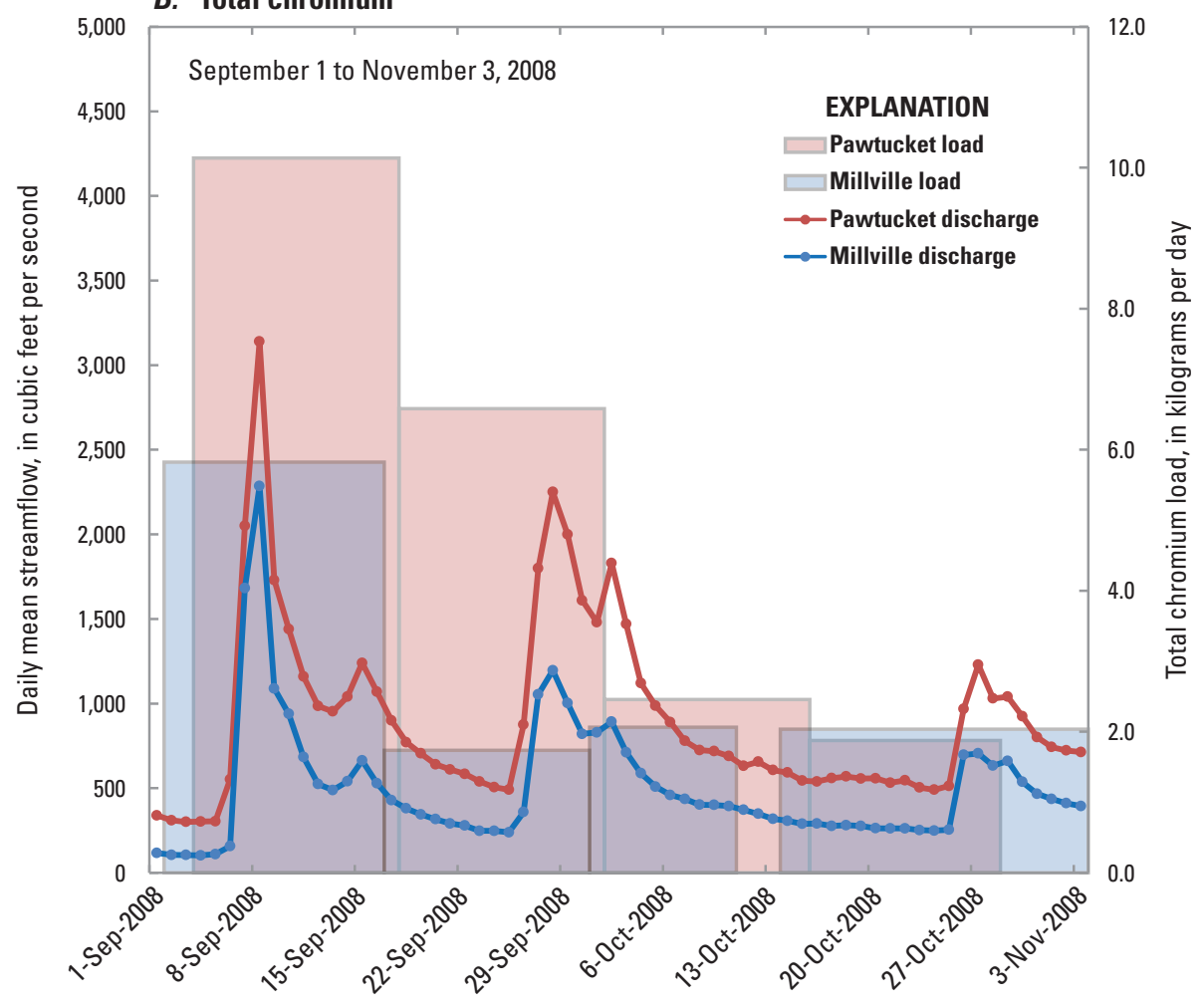

Figure 8. Loads of $A$, total cadmium, $B$, total chromium, $C$, total copper, $D$, total lead, $E$, total nickel, and $F$, total zinc and streamflow in the Blackstone River at monitoring stations at Millville, Massachusetts (01111230), and Pawtucket, Rhode Island (01113895), from September 1 to November 3, 2008. 
C. Total copper

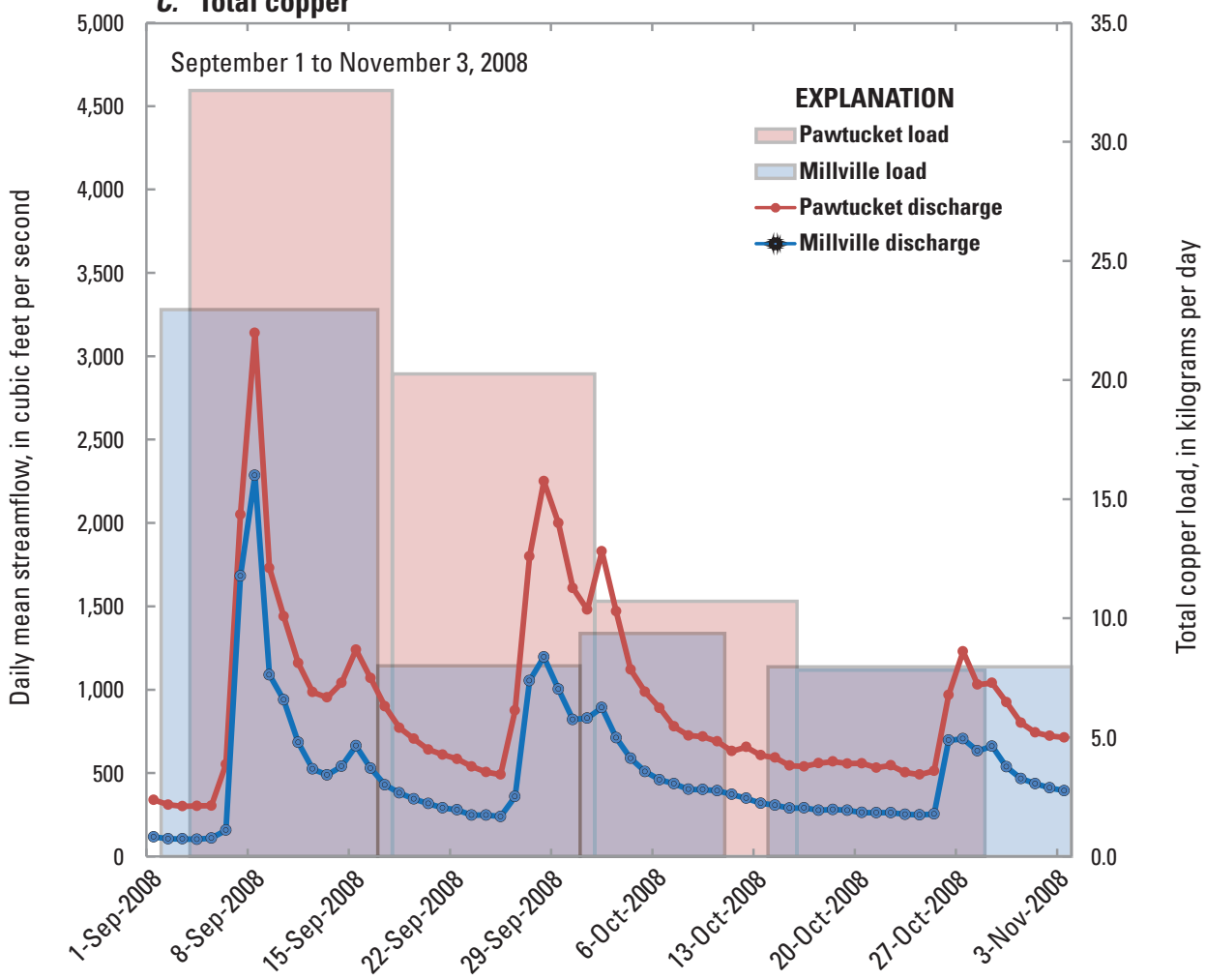

D. Total lead

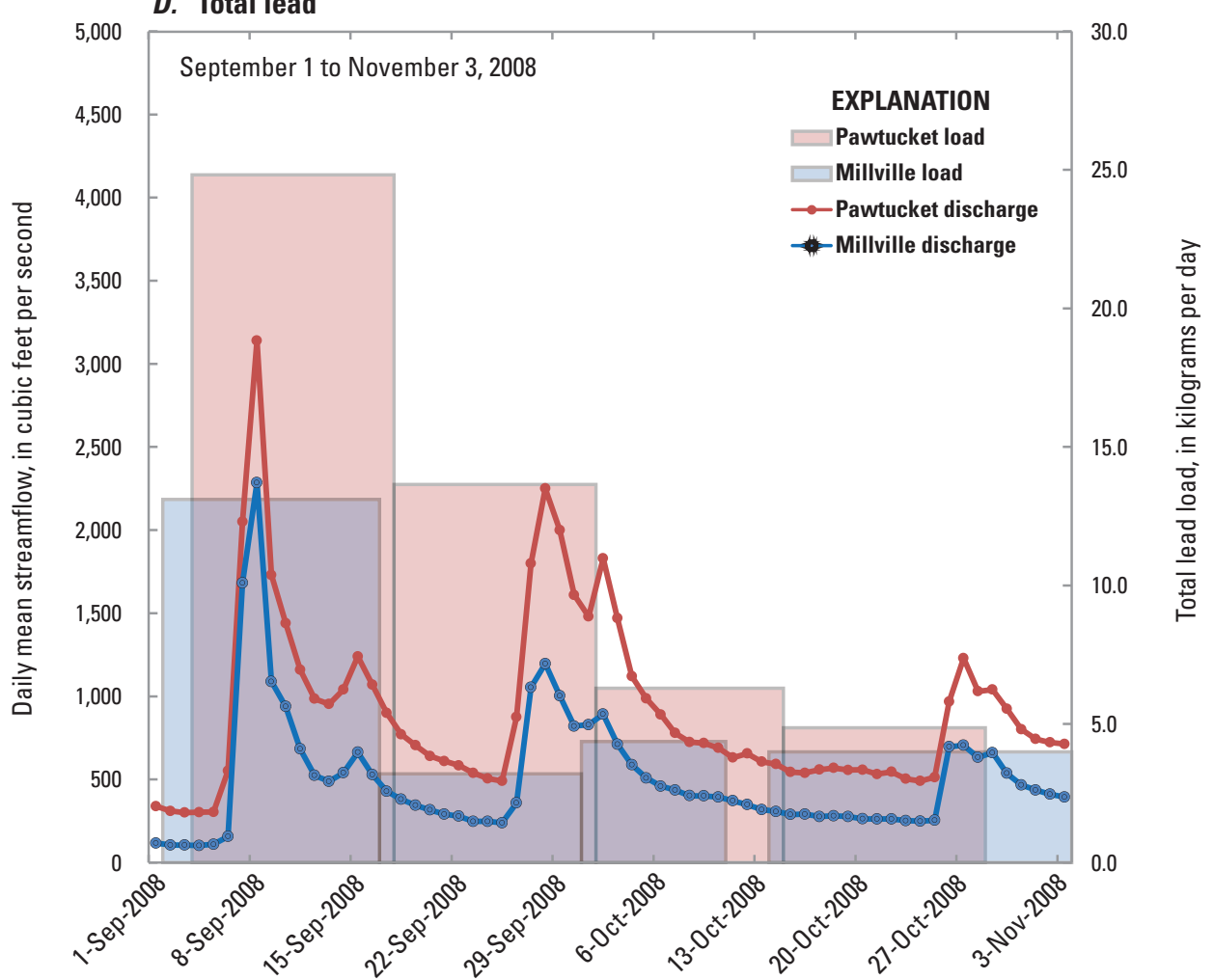

Figure 8. Loads of $A$, total cadmium, $B$, total chromium, $C$, total copper, $D$, total lead, $E$, total nickel, and $F$, total zinc and streamflow in the Blackstone River at monitoring stations at Millville, Massachusetts (01111230), and Pawtucket, Rhode Island (01113895), from September 1 to November 3, 2008.-Continued 

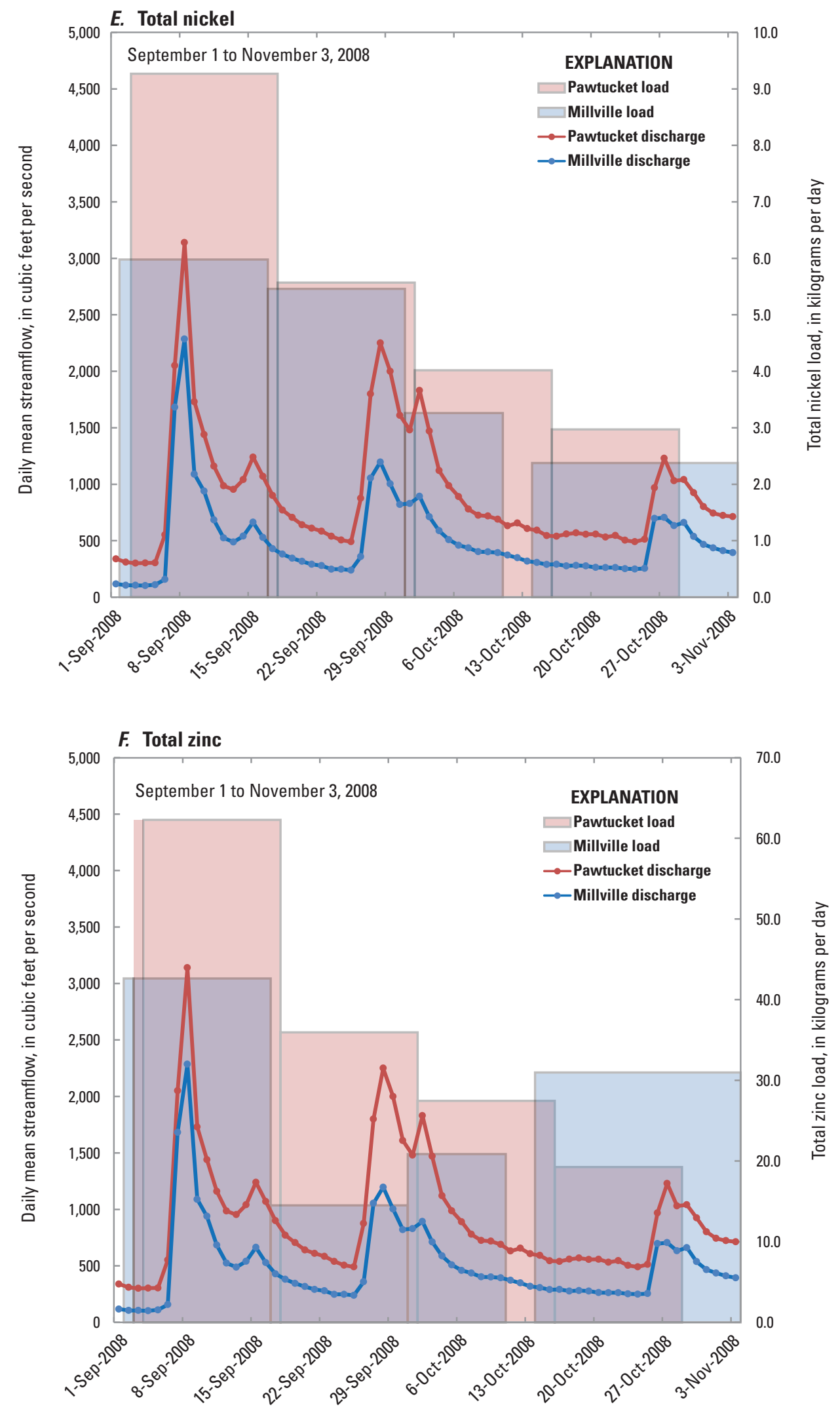

Figure 8. Loads of $A$, total cadmium, $B$, total chromium, $C$, total copper, $D$, total lead, $E$, total nickel, and $F$, total zinc and streamflow in the Blackstone River at monitoring stations at Millville, Massachusetts (01111230), and Pawtucket, Rhode Island (01113895), from September 1 to November 3, 2008.-Continued 


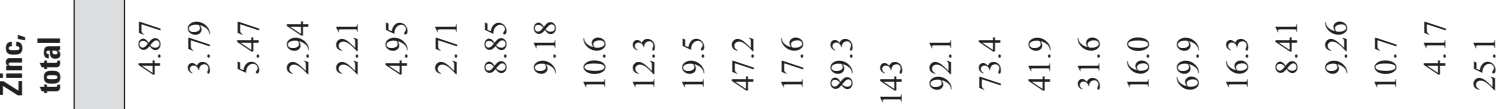

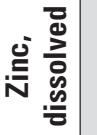

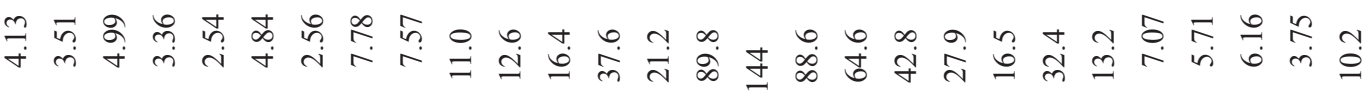

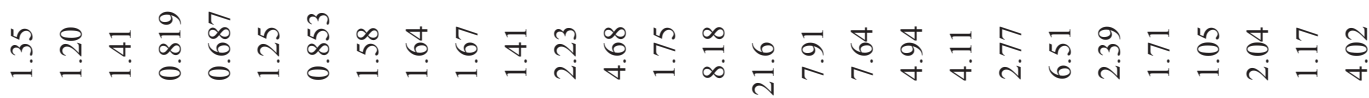

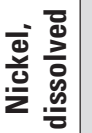

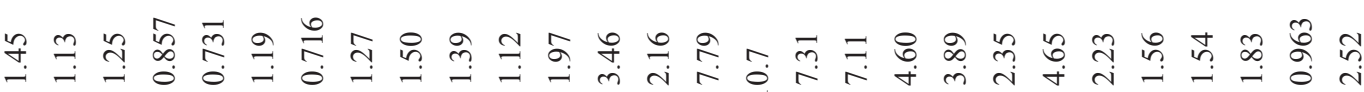

离 $\overline{\frac{\mathrm{m}}{\mathbf{a}}}$

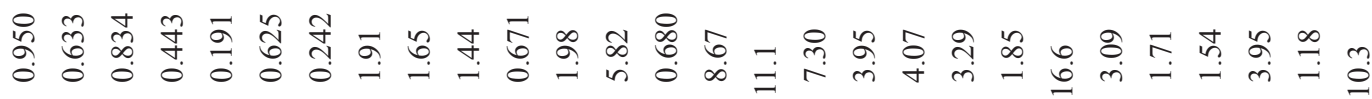

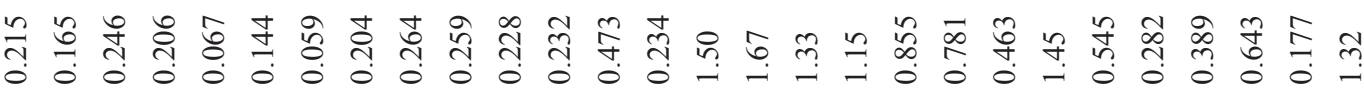

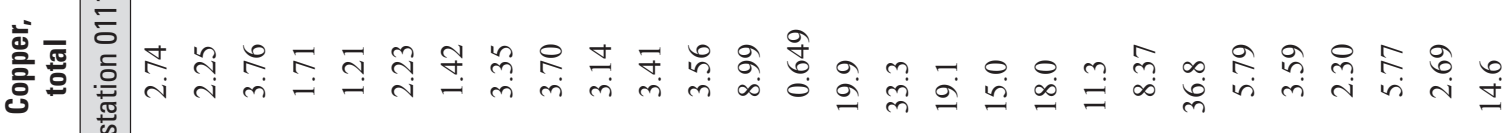

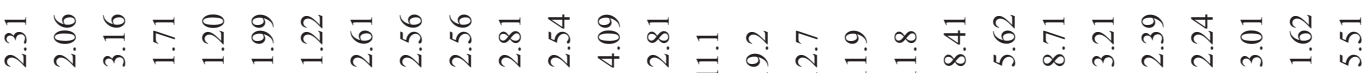

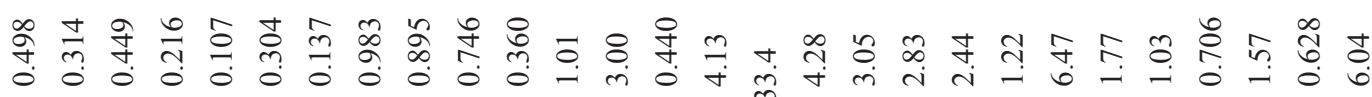

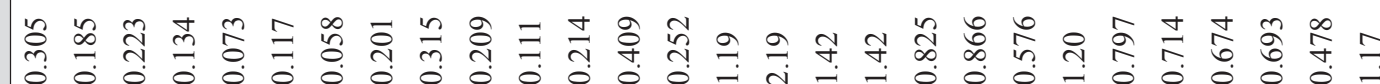

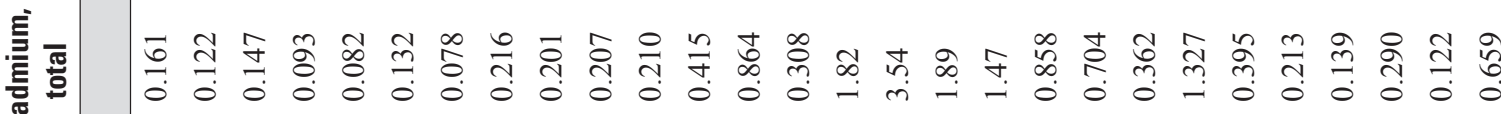

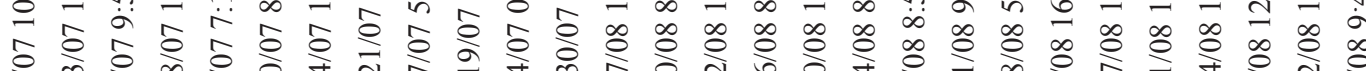

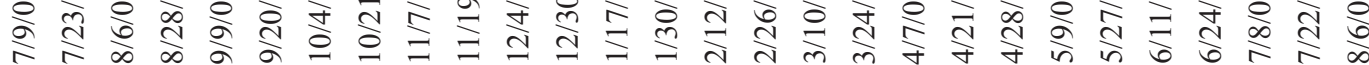

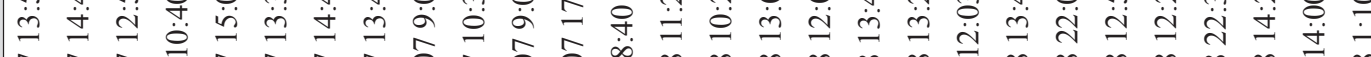

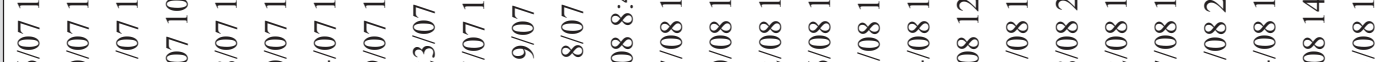

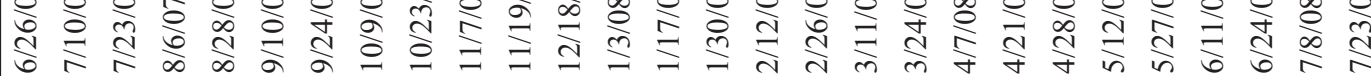




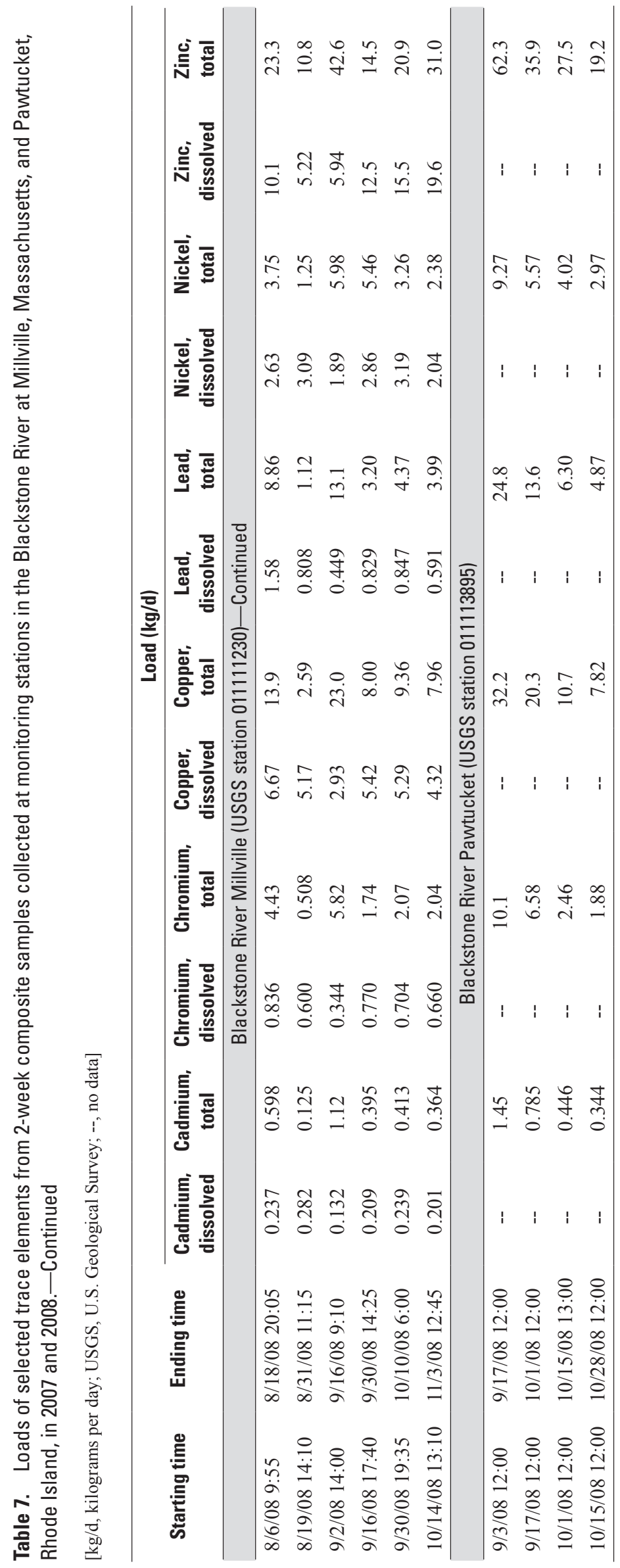


the total masses of total phosphorus and suspended sediment were 14,000 and $1,800,000 \mathrm{~kg}$, respectively. Loads of total nitrogen, total phosphorus, and suspended sediment at the Millville station during this sampling period also were among the largest measured at that monitoring station.

The comparison of total nitrogen and total phosphorus loads in the Blackstone River at the Millville and Pawtucket stations suggests that have been sources of these constituents to the river downstream of the Millville monitoring station. The median difference in total loads between the Millville and Pawtucket stations for the individual sampling periods was $680 \mathrm{~kg} / \mathrm{d}$ for total nitrogen and $52 \mathrm{~kg} / \mathrm{d}$ for total phosphorus, representing about 30 percent (total nitrogen) and about 25 percent (total phosphorus) of the loads at the Pawtucket monitoring station. Potential sources in the drainage area between the Millville and Pawtucket stations, which is relatively large $\left(212 \mathrm{mi}^{2}\right)$, include the Woonsocket wastewater treatment plant, inflow from tributaries, and direct runoff to the river. These potential sources were not directly monitored in this study. Information on discharge volumes and nitrogen concentrations was provided by the Woonsocket wastewater treatment plant. Nitrogen loads calculated from these data ranged from 66 to $156 \mathrm{~kg} / \mathrm{d}$, with a median value of $95 \mathrm{~kg} / \mathrm{d}$ for the six sampling periods for which data were available, generally much smaller than the total difference in nitrogen load between the Millville and Pawtucket monitoring stations. Estimates of loads from the unmonitored area between the Millville and Pawtucket stations, using the yields from the three monitored tributaries in Massachusetts for the analysis of nitrogen attenuation, indicates that these loads may be large enough to account for the remaining difference between the loads at the Millville and Pawtucket stations in some sampling periods.

Loads of total cadmium, chromium, copper, lead, nickel, and zinc were larger at the Pawtucket monitoring station than at the upstream Millville station during most of the 2-month period when these constituents were monitored at both stations in the latter part of water year 2008 (fig. 8). In the last sampling period, at the end of October 2008, loads of total cadmium, chromium, copper, and zinc at the Millville station were slightly larger than or about equal to loads at the Pawtucket station. The largest loads of all trace elements were measured during the early September 2008 sampling period. The highest streamflow during the 2-month period also was measured at this time, in a short, intense, runoff event. Loads decreased steadily from early September through October 2008 (fig .8; table 7); streamflow also decreased.

A relation between loads of trace elements and streamflow also was seen more generally at the Millville station where trace element loads were measured throughout water year 2008. Trace element loads at the Millville station increased to their maximum levels during winter 2008 (table 7), when streamflow was seasonally high. Another peak in trace element loads at Millville occurred in fall 2008, again in association with increased streamflow.

\section{Potential for Resuspension and Transport of Trace Element- and Nutrient-Enriched Bottom Sediment From Two Blackstone River Impoundments}

Impoundments on the Blackstone River have been identified as major sources of particulate trace element and nutrient contamination, especially during periods of increased flow due to storms (Wright and others, 2001). The Blackstone River initiative, a multistate, multiagency effort to assess water and sediment quality in the river, was designed to gather data and modeling results to document changing conditions in the river (Wright and others, 2001). The study identified resuspension of previously deposited bottom sediment as a major source of trace element loading in the river.

This section of the report describes the study design and results of an evaluation of the extent and potential effects of sediment resuspension on contaminant loading in Blackstone River impoundments. First, the effects of precipitation and subsequent changes in streamflow on turbidity are examined. Next, linear regression equations are developed to (1) relate turbidity to concentrations of selected constituents of concern and (2) use these equations to generate time series of concentrations of these constituents. Concentrations of a subset of constituents representing trace elements, nutrients, and suspended sediment are used to estimate loads and the changes in loads that occurred in the impoundments in response to storms. Finally, relations between the magnitudes of storm flows and the resultant changes in loads of particulate constituents during passage through the reservoirs are quantified and compared.

Two run-of-the-river impoundments typical of those along the river were selected for investigation-Rice City Pond and the former Rockdale Pond (figs. 9A-B). Operations of the Northbridge wastewater treatment plant and the Riverdale Dam (hydropower), situated between the two impoundments, cause diel fluctuations in water levels in both areas.

The Rockdale Mill Pond Dam, constructed in 1856, originally impounded 15 acres just upstream from Northbridge, Mass., between about 30 and 32 river miles upstream from the mouth (Vanasse Hangen Brustlin, Inc., 2005). The dam was breached and removed in the late 1960s. The riverbanks included a former toxic waste site (chlorinated solvents) and remained devoid of vegetation cover (fig. 9A). Concerns were expressed in the Blackstone River restoration study (U.S. Army Corps of Engineers, 1994) and by the Blackstone River initiative (Wright and others, 2001) that the exposed banks of the former impoundment would be subject to erosion during high flows, thus mobilizing toxic metals and other contaminants. 

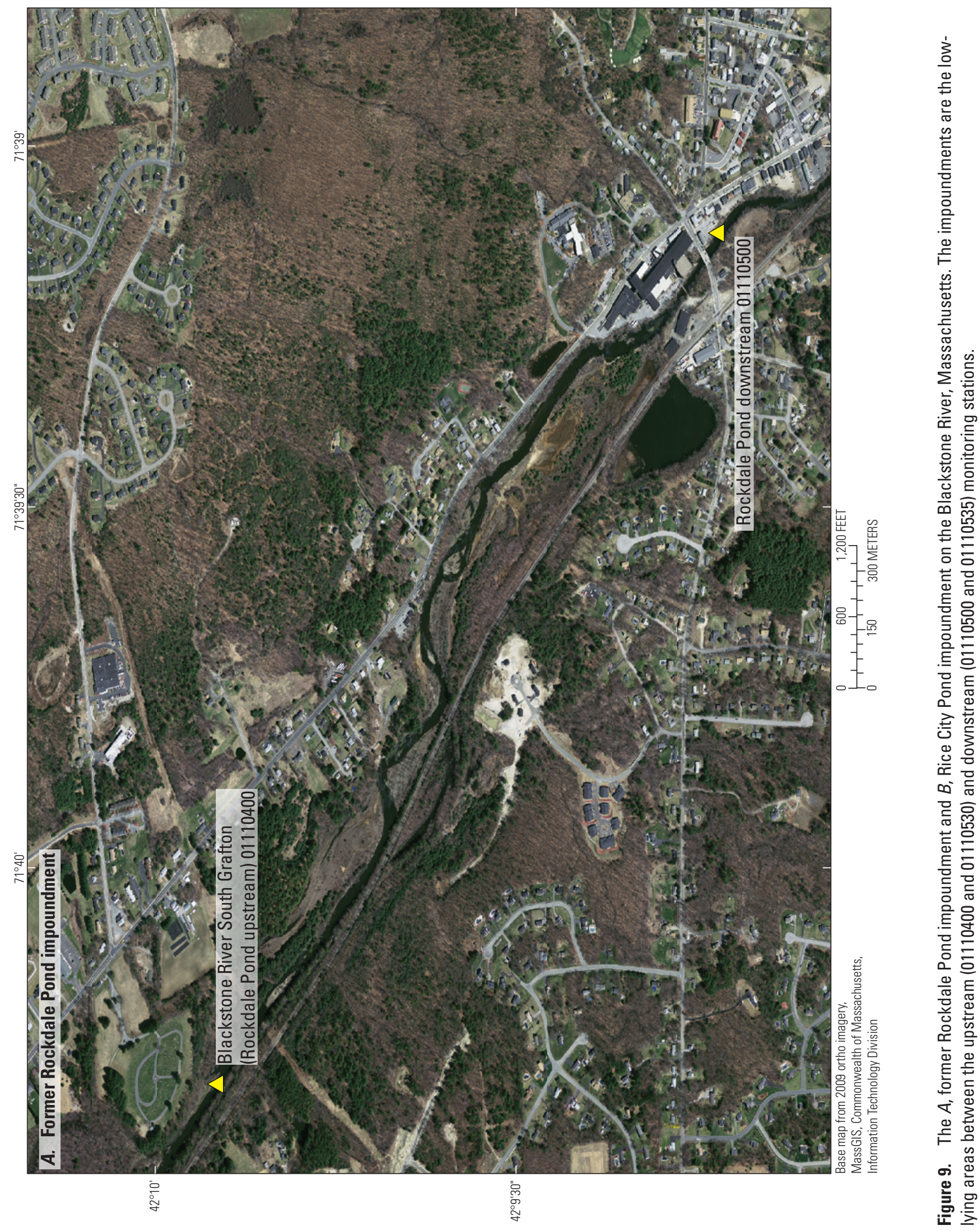


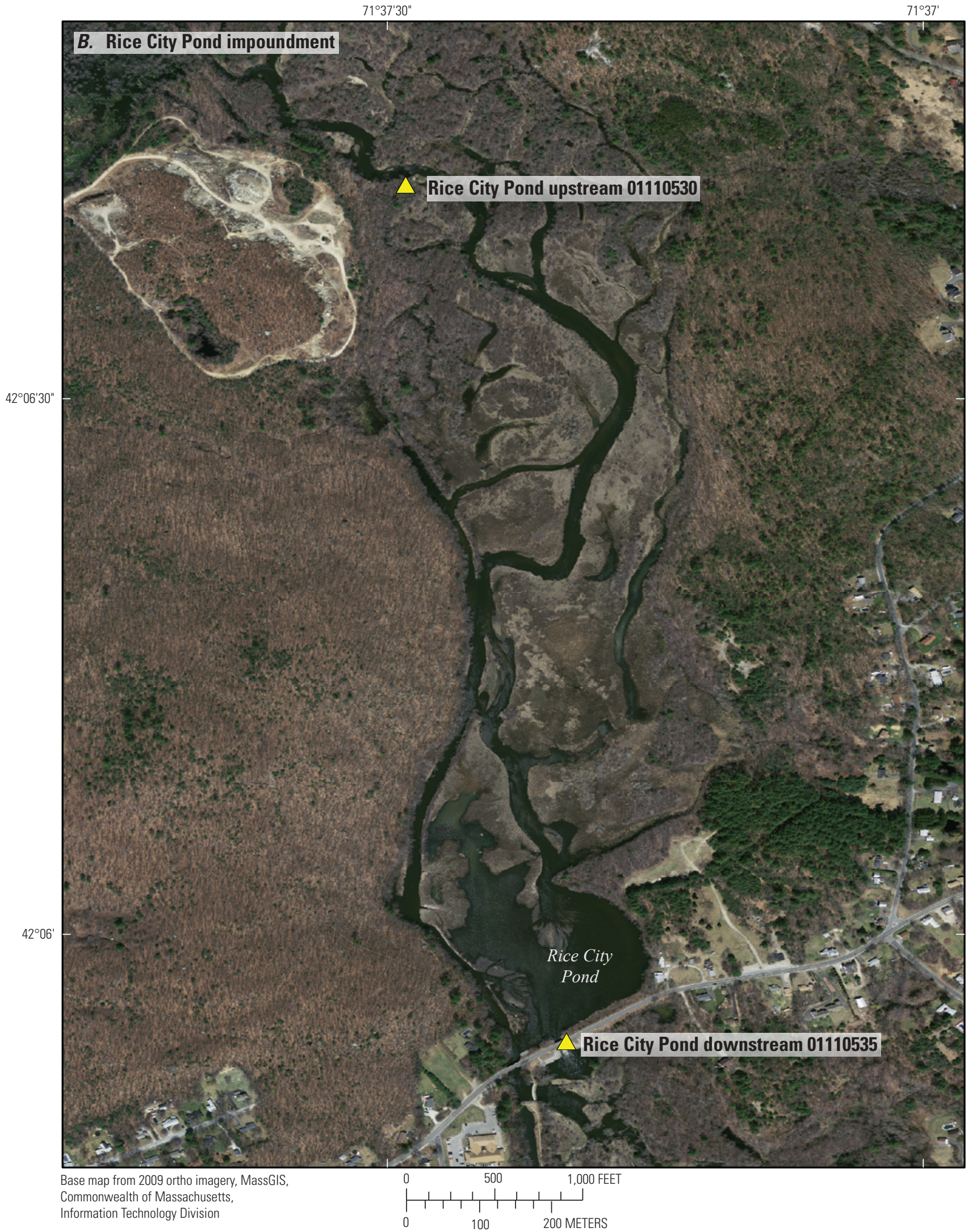

Figure 9. The $A$, former Rockdale Pond impoundment and $B$, Rice City Pond impoundment on the Blackstone River, Massachusetts. The impoundments are the low-lying areas between the upstream (01110400 and 01110530) and downstream (01110500 and 01110535) monitoring stations.-Continued 
Rice City Pond, a 105-acre impoundment on the Blackstone River in Uxbridge and Northbridge, was originally constructed in 1865 to provide a reliable water supply for the Blackstone Canal (Vanasse Hangen Brustlin, Inc., 2005). In 1955, the earthen dam burst due to high flows associated with Hurricane Diane and was replaced with a concrete structure (U.S. Army Corps of Engineers, 1997). Reconnaissance studies associated with the formation of the Blackstone River Corridor national historic site found high levels of trace elements, polycyclic aromatic hydrocarbons and petroleum in the impounded bed sediments (Wright and others, 2001).

The Blackstone River initiative found that Rice City Pond served as a settling basin for particulate contaminants at low flows and suggested that these particles could be mobilized at higher flows and transported downstream (Wright and others, 2001). Rice City Pond was found to be the most important source of total suspended solids, chromium, and lead, and, during high flows, copper of any station on the river. Concentrations of cadmium, chromium, copper, nickel, and zinc were all found to increase substantially downstream of the dam during high-flow events associated with storms. These findings, together with the reduction in hardness due to dilution during high flows, led to violations of trace element-concentration criteria during the study period (Wright and others, 2001). The results also suggested that wet-weather loadings could dominate the river for days after storms, depending on the magnitude of the storm and the constituent considered.

In order to assess hypothesized relations among turbidity, streamflow, and transport of suspended sediment, nutrients, and trace elements, monitoring stations with continuously operating turbidity probes (15-minute intervals) were established on the Blackstone River upstream and downstream from Rice City Pond and from the former Rockdale Pond. Streamflow was also monitored continuously (15-minute intervals) at these stations. The stations were as follows: (1) 01110400, Blackstone River South Grafton (former Rockdale Pond upstream); (2) 01110500, (former) Rockdale Pond downstream; (3) 01110530, Rice City Pond upstream; and (4) 01110535, Rice City Pond outlet or downstream (fig. 1; table 1). The Blackstone River South Grafton (former Rockdale Pond upstream station, 01110400) is also a station at which loads of nitrogen, phosphorus, and suspended sediment were monitored and is referred to as the Blackstone River South Grafton station in sections of the report that describe constituent loads; the station is referred to as the former Rockdale Pond upstream station in this section of the report.

\section{Turbidity Patterns in Relation to Streamflow and Precipitation}

Turbidity is a measure of the degree to which the water loses its transparency due to the presence of particulates suspended in the water column. Submersible sondes outfitted with turbidity probes were deployed during water year 2008 (October 2007 through September 2008) to continuously (at 15-minute intervals) monitor turbidity in order to obtain data to use in developing mathematical relations between turbidity and concentrations of suspended sediment, nutrients, and trace elements.

Turbidity patterns recorded during water year 2008 show long periods (days to weeks) at all four stations when the turbidity was substantially less than 50 formazin nephelometric units (FNU; figs. 10-12). Turbidity exceeded 50 FNU at the upstream monitoring stations more often than at the downstream stations. The low-flow periods, characterized by relatively low turbidity, are interspersed with brief (less than 48-hour) intervals with elevated turbidity values.

During low-flow periods in autumn 2007 and summer 2008 , the timing of the increases in turbidity appears to be directly related to streamflow; for example, at the former Rockdale Pond upstream station (01110400), turbidity was less than 50 FNU and usually less than 20 FNU from midOctober to mid-December 2007. Streamflow during this period rarely exceeded about $100 \mathrm{ft}^{3} / \mathrm{s}$, despite the occurrence of at least four storms in the watershed with rainfall totals on the order of 1 inch (in.).

Increases in streamflow, especially to rates larger than $500 \mathrm{ft}^{3} / \mathrm{s}$, were generally associated with short-lived spikes in turbidity to levels as high as $200 \mathrm{FNU}$, for example, on December 24, 2007, at the former Rockdale Pond upstream station (01110400). In this case, a storm with precipitation of about $0.75 \mathrm{in}$. caused the streamflow to increase only to about $250 \mathrm{ft}^{3} / \mathrm{s}$ but presumably caused resuspension of sediment particles upstream from the monitoring station. Within 24 hours, the turbidity readings returned to predisturbance levels. Turbidity remained low for the next several days until another relatively large storm, on January 11, 2008, with 1.2 in. of precipitation, produced a large increase in streamflow $\left(650 \mathrm{ft}^{3} / \mathrm{s}\right)$. The turbidity response to this storm, with a peak of $91 \mathrm{FNU}$, however, was substantially smaller than the previous storm's peak. One explanation for this difference is that the surficialsediment deposits that were resuspended by the December 24 streamflow increase had accumulated during the previous low-flow period during which sediments were deposited; the surficial-sediment deposits were depleted when the January 11 storm struck, and the effect on turbidity was diminished.

Detailed examination of turbidity data from all four monitoring stations during short time periods with rapid changes in streamflow helps to explain the effects of streamflow on turbidity. As streamflow increased to its peak during the December 24, 2007, storm (fig. 12A), the turbidity values began to rise as well. Turbidity values at individual monitoring stations reached their peaks in downstream order. The turbidity peak at the upstream end of the former Rockdale Pond (station 01110400) was larger than the peak at the downstream end (station 01110500), and the peak at the upstream end of Rice City Pond (station 01110530) was smaller than the peak at the impoundment's downstream end (station 01110535). These patterns suggest that the two river sections were behaving differently with respect to resuspension and transport of previously deposited bed 

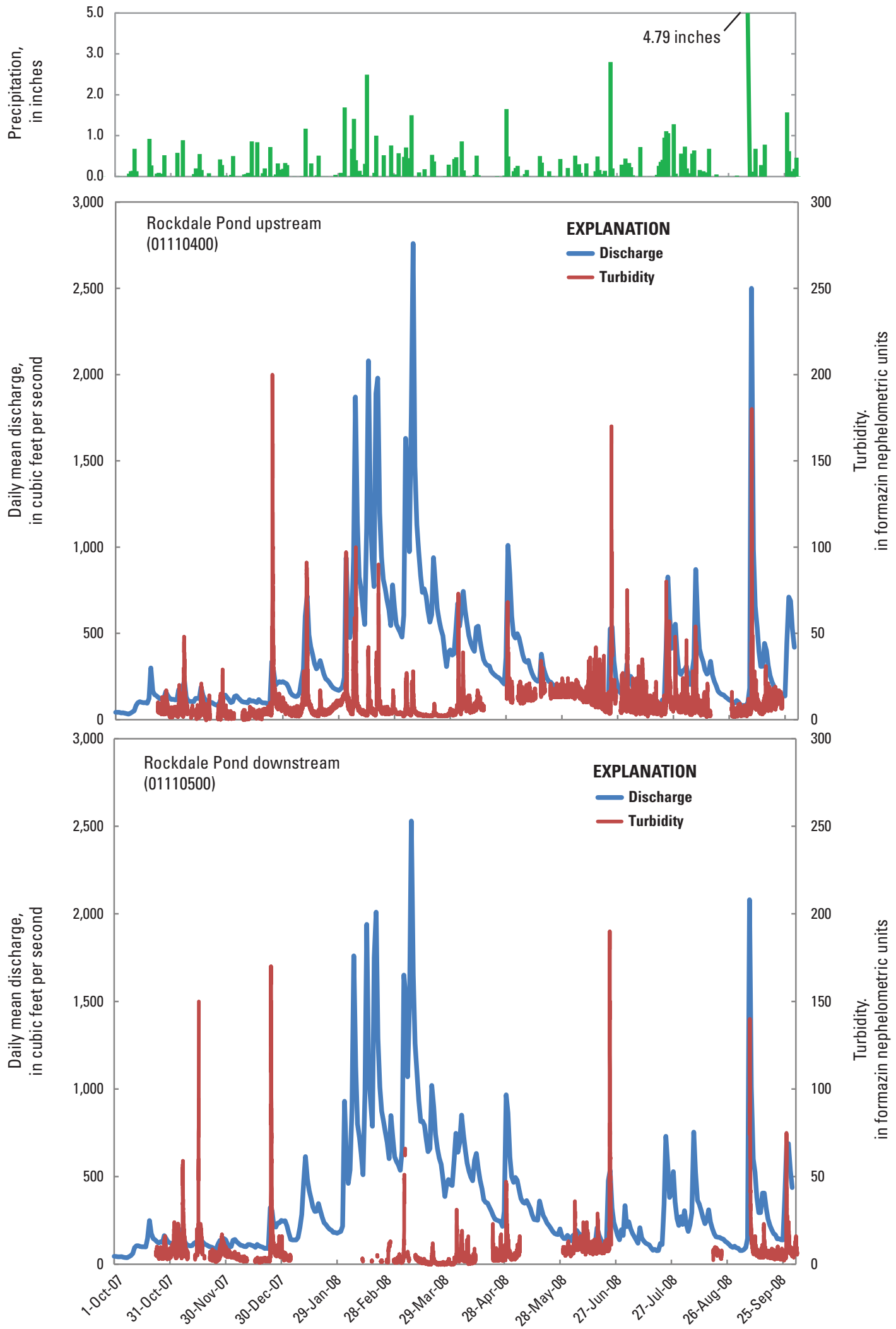

Figure 10. Turbidity patterns at Blackstone River monitoring stations upstream (01110400) and downstream (01110500) from the former Rockdale Pond impoundment on the Blackstone River, Massachusetts, during water year 2008, in relation to measured streamflow at the monitoring station and to precipitation at the Upper Blackstone Water Pollution Control Abatement District wastewater treatment plant in Millbury, Mass. 


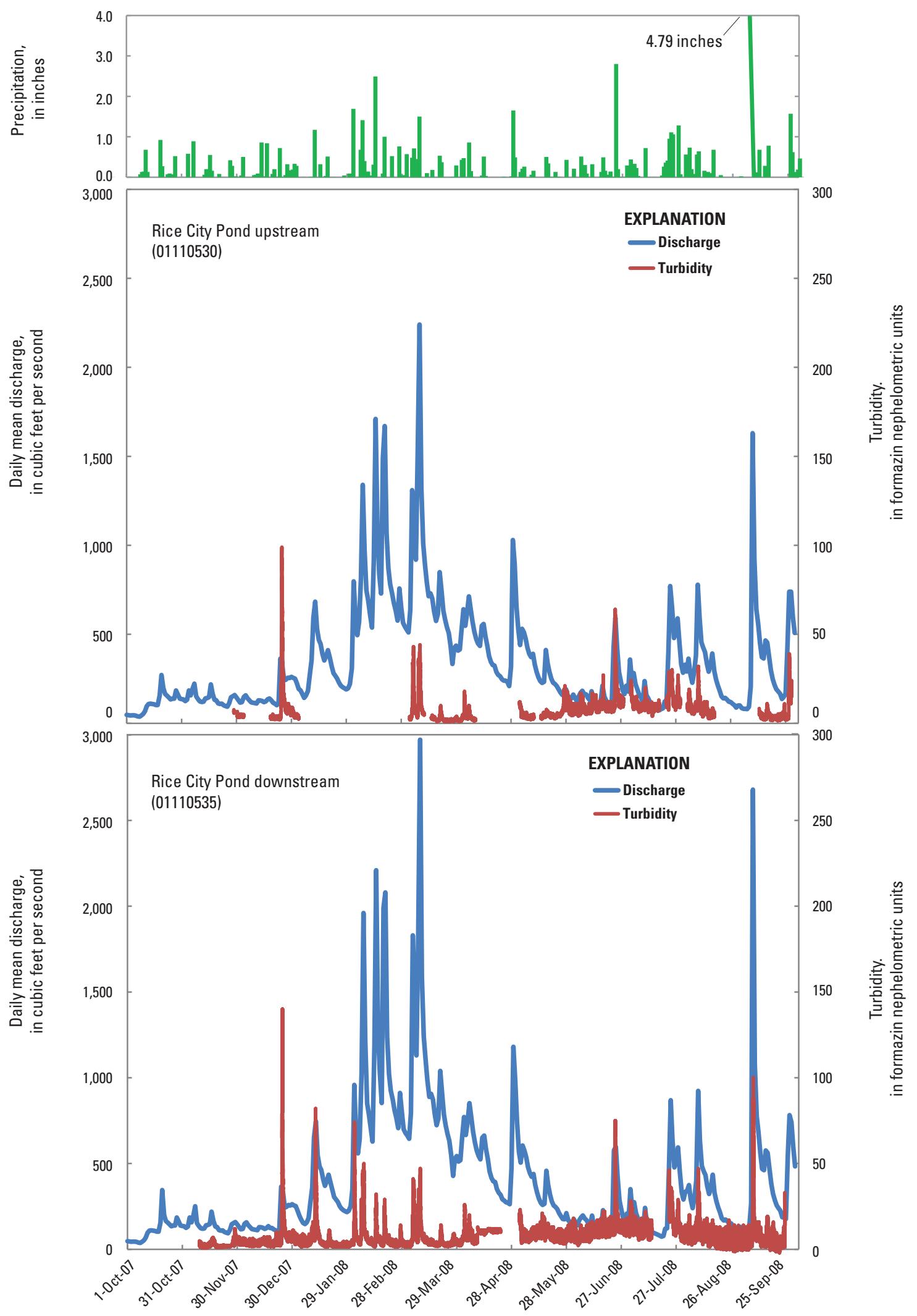

Figure 11. Turbidity patterns at Blackstone River monitoring stations upstream (01110530) and downstream (01110535) from the Rice City Pond impoundment on the Blackstone River, Massachusetts, during water year 2008, in relation to measured streamflow at the monitoring station and to precipitation at the Upper Blackstone Water Pollution Control Abatement District wastewater treatment plant in Millbury, Mass. 
A. December 22 to 28, 2007

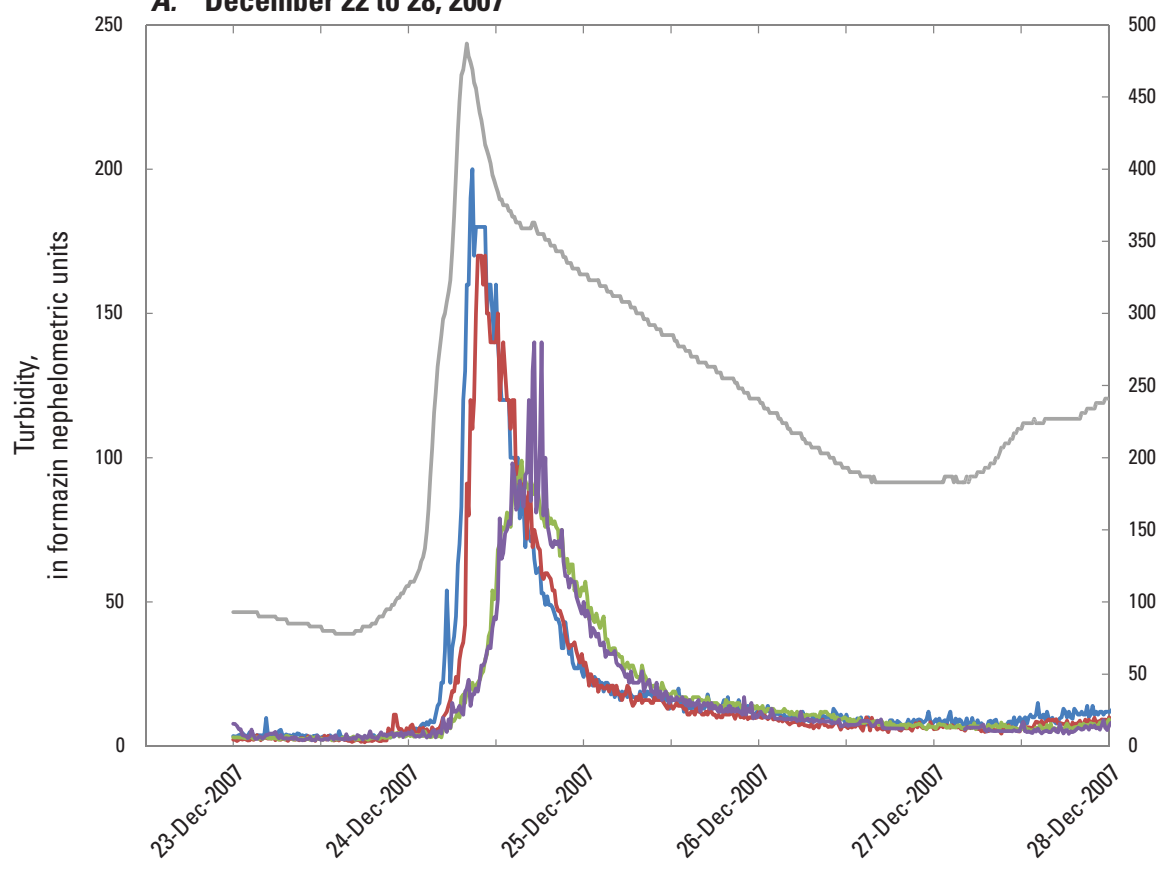

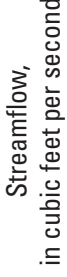

B. March 15 to April 4, 2008

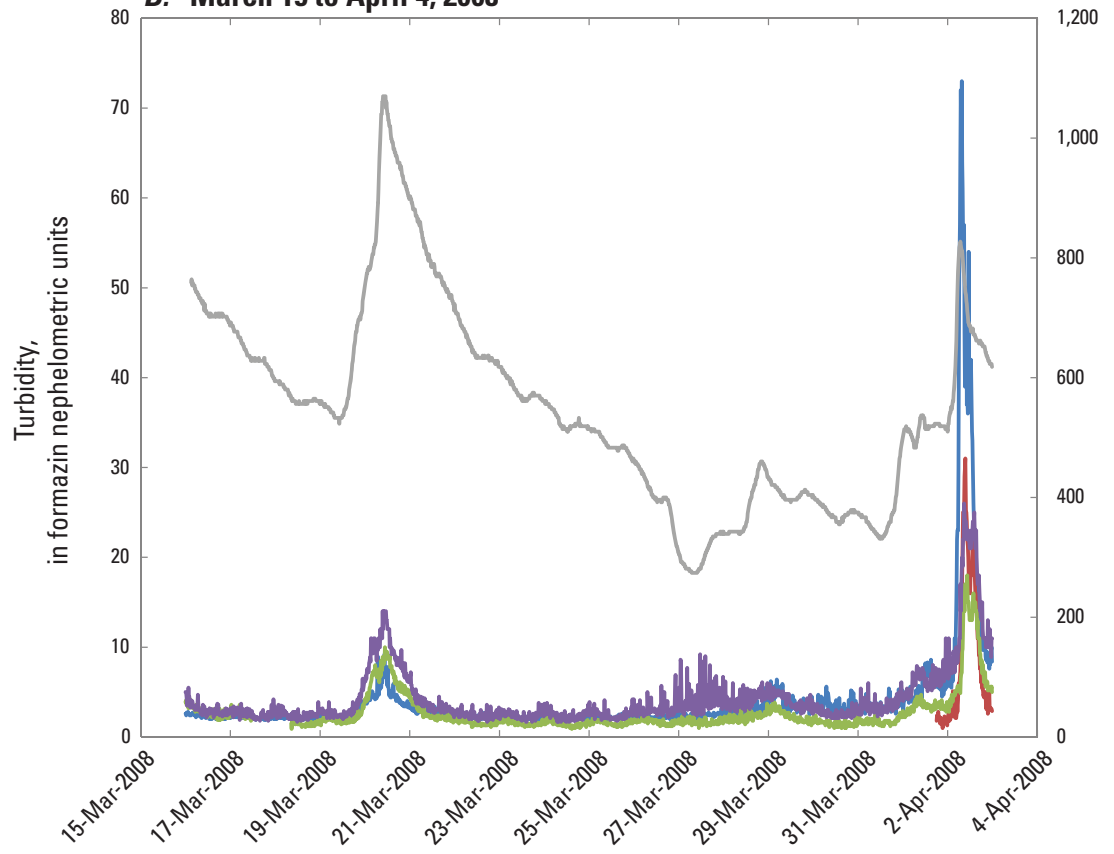

EXPLANATION

Streamflow

Rockdale Pond

upstream $(01110400$

Turbidity

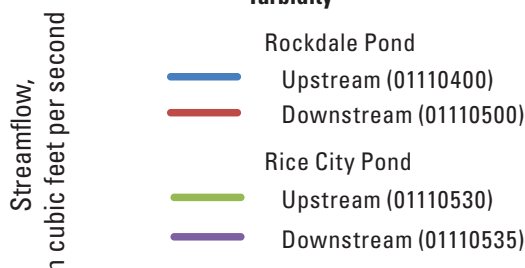

Figure 12. Turbidity patterns at four Blackstone River monitoring stations upstream and downstream from the former Rockdale Pond and Rice City Pond impoundment on the Blackstone River, Massachusetts, in relation to measured streamflow at during the $A$, December 22 to 28, 2007, and B, March 15 to April 4, 2008, storms. Streamflow at all four stations was similar and is represented by streamflow at the Rockdale Pond upstream station. 
sediment. High flow resulted in sediment resuspension and downstream transport in the intact impoundment (Rice City Pond); in contrast, sediment resuspended in the breached impoundment (the former Rockdale Pond) was not transported downstream but was quickly redeposited within the reach.

In mid-March to early April 2008, two storms took place about 2 weeks apart (fig. 12B). The streamflow during these storms was substantially larger than that of the December 2007 storm. The first storm in March 2008 resulted in turbidity peaks that barely exceeded $10 \mathrm{FNU}$; the peak turbidities of the second storm in April 2008 ranged from about 20 FNU to slightly more than $70 \mathrm{FNU}$, despite the fact that the maximum flow was about 30 percent lower during the second storm than it was for the first. As in the case of the December 2007 storm, the peak turbidity at the upstream end of the former Rockdale Pond was larger than at its downstream end, and the peak turbidity at the upstream end of Rice City Pond was less than at its downstream end. Again, the intact impoundment acted as a source of sediment, whereas the breached impoundment acted more as a sink.

\section{Turbidity as a Surrogate for Particulate Trace Elements, Nutrients, and Suspended Sediment}

The main purpose of the turbidity study was to evaluate the effects of sediment resuspension on mobilization and transport of contaminants that were previously deposited in the impoundments, either behind a dam (Rice City Pond) or along the exposed banks of a channel that cut through a former impoundment (the former Rockdale Pond). To accomplish this, it was necessary to develop relations between turbidity and measured concentrations of nutrients and trace elements at the four streamflow and water-quality monitoring stations to estimate concentrations for these constituents between sampling events. Estimated concentration data were then combined with flow records to estimate loads. Linearregression models were constructed for relations between concentrations of particle-bound trace elements, particlebound phosphorus, and suspended sediment, and measured turbidity using data collected during water year 2008 at each of the stations (table 8). The particulate concentrations all were strongly and positively correlated with turbidity. The median coefficient of determination $\left(R^{2}\right)$ for all selected constituents at the four monitoring stations was 0.881 ; the minimum $R^{2}$ was 0.662 and the maximum $R^{2}$ was 0.985 . As expected, correlations between turbidity and suspended sediment concentrations were strong. The lowest $R^{2}$ value for turbidity and suspended sediment concentrations was 0.843 and the highest was 0.985 ; the slopes of the linear regressions ranged from 1.15 to 1.52 .

About 10 percent of the turbidity readings for this part of the study detailed in this report (stations upstream and downstream from impoundments) provided constituent concentrations that were outside the ranges of the calibration curves for the trace elements, nutrients, and suspended
Table 8. Variables of linear regression equations for constituent loads and measured turbidity for four streamflow and water-quality-monitoring stations on the Blackstone River, Massachusetts, during water year 2008.

$\left[R^{2}\right.$, coefficient of determination, $\mathrm{n}$, number of samples; USGS, U.S. Geological Survey; $\mu \mathrm{g} / \mathrm{L}$, micrograms per liter; mg/L, milligrams per liter]

\begin{tabular}{|c|c|c|c|c|}
\hline Constituent & Slope & Intercept & $R^{2}$ & $\mathbf{n}$ \\
\hline \multicolumn{5}{|c|}{$\begin{array}{l}\text { Blackstone River South Grafton } \\
\text { (Rockdale Pond upstream; USGS station 01110400) }\end{array}$} \\
\hline Particulate cadmium $(\mu \mathrm{g} / \mathrm{L})$ & 0.0285 & 0.0557 & 0.881 & 6 \\
\hline Particulate chromium $(\mu \mathrm{g} / \mathrm{L})$ & 0.0284 & -0.2164 & 0.977 & 6 \\
\hline Particulate copper $(\mu \mathrm{g} / \mathrm{L})$ & 0.7876 & -1.1521 & 0.926 & 6 \\
\hline Particulate lead $(\mu \mathrm{g} / \mathrm{L})$ & 0.8287 & -0.9724 & 0.955 & 6 \\
\hline Particulate nickel $(\mu \mathrm{g} / \mathrm{L})$ & 0.0890 & -0.3752 & 0.915 & 6 \\
\hline Particulate zinc $(\mu \mathrm{g} / \mathrm{L})$ & 0.9878 & -1.1173 & 0.833 & 6 \\
\hline Particulate phosphorus (mg/L) & 0.0087 & 0.0735 & 0.662 & 6 \\
\hline Suspended sediment (mg/L) & 1.2679 & 2.8331 & 0.843 & 6 \\
\hline \multicolumn{5}{|c|}{ Rockdale Pond downstream (USGS station 01110500) } \\
\hline Particulate cadmium $(\mu \mathrm{g} / \mathrm{L})$ & 0.0234 & 0.0466 & 0.864 & 7 \\
\hline Particulate chromium $(\mu \mathrm{g} / \mathrm{L})$ & 0.1444 & 0.7006 & 0.830 & 7 \\
\hline Particulate copper $(\mu \mathrm{g} / \mathrm{L})$ & 0.4847 & 1.6157 & 0.880 & 7 \\
\hline Particulate lead $(\mu \mathrm{g} / \mathrm{L})$ & 0.5182 & 0.7887 & 0.927 & 7 \\
\hline Particulate nickel $(\mu \mathrm{g} / \mathrm{L})$ & 0.0455 & 0.6396 & 0.915 & 7 \\
\hline Particulate zinc $(\mu \mathrm{g} / \mathrm{L})$ & 0.8392 & -0.7157 & 0.833 & 7 \\
\hline Particulate phosphorus (mg/L) & 0.0079 & 0.0656 & 0.822 & 7 \\
\hline Suspended sediment (mg/L) & 1.1463 & 2.9250 & 0.948 & 7 \\
\hline \multicolumn{5}{|c|}{ Rice City Pond upstream (USGS station 01110530) } \\
\hline Particulate cadmium $(\mu \mathrm{g} / \mathrm{L})$ & 0.0219 & 0.0377 & 0.825 & 7 \\
\hline Particulate chromium $(\mu \mathrm{g} / \mathrm{L})$ & 0.1660 & 0.7055 & 0.890 & 7 \\
\hline Particulate copper $(\mu \mathrm{g} / \mathrm{L})$ & 0.4763 & 1.3748 & 0.885 & 7 \\
\hline Particulate lead $(\mu \mathrm{g} / \mathrm{L})$ & 0.5001 & 0.9877 & 0.927 & 7 \\
\hline Particulate nickel $(\mu \mathrm{g} / \mathrm{L})$ & 0.0567 & -0.0711 & 0.930 & 7 \\
\hline Particulate zinc $(\mu \mathrm{g} / \mathrm{L})$ & 0.9699 & -1.2395 & 0.914 & 7 \\
\hline Particulate phosphorus (mg/L) & 0.0093 & 0.0658 & 0.831 & 7 \\
\hline Suspended sediment (mg/L) & 1.2462 & 2.8775 & 0.891 & 7 \\
\hline \multicolumn{5}{|c|}{ Rice City Pond outlet (USGS station 01110535) } \\
\hline Particulate cadmium $(\mu \mathrm{g} / \mathrm{L})$ & 0.0228 & 0.1292 & 0.684 & 7 \\
\hline Particulate chromium $(\mu \mathrm{g} / \mathrm{L})$ & 0.1887 & 0.8303 & 0.788 & 7 \\
\hline Particulate copper $(\mu \mathrm{g} / \mathrm{L})$ & 0.4154 & 2.8959 & 0.795 & 7 \\
\hline Particulate lead $(\mu \mathrm{g} / \mathrm{L})$ & 0.4677 & 1.4896 & 0.863 & 7 \\
\hline Particulate nickel ( $\mu \mathrm{g} / \mathrm{L})$ & 0.0596 & 0.0104 & 0.849 & 7 \\
\hline Particulate zinc $(\mu \mathrm{g} / \mathrm{L})$ & 0.8948 & 0.4081 & 0.802 & 7 \\
\hline Particulate phosphorus (mg/L) & 0.0102 & 0.0581 & 0.885 & 7 \\
\hline Suspended sediment (mg/L) & 1.5177 & -0.5460 & 0.985 & 7 \\
\hline
\end{tabular}


sediment, but were nevertheless used in regression development. The decision to use turbidity readings outside of the ranges of calibration curves was based on previous research (Métadier and Bertrand-Krajewski, 2012) showing that these linear relations are maintained outside the calibration ranges.

\section{Effects of Sediment Resuspension on Contaminant Concentrations and Loads}

Effects of sediment resuspension on particulate trace element concentrations are best determined by examining high-flow periods. During low-flow periods, resuspension is minimal and turbidity is consistently low. Sampling periods were selected for analysis because they represented times when the turbidity records were complete, that is, without gaps caused by equipment problems. Graphs presented in this section depict the estimated particulate constituent concentrations calculated using the individual regression equations for each monitoring station.

\section{Changes in Trace Element Concentrations Resulting From Sediment Resuspension}

At the former Rockdale Pond upstream monitoring station (01110400), daily mean streamflow increased from $88 \mathrm{ft}^{3} / \mathrm{s}$ on December 23, 2007 to $336 \mathrm{ft}^{3} / \mathrm{s}$ on December 24, 2007 (fig. 13A). Streamflow at the station began to decrease after peaking on December 24 but remained higher than it was before the event. The increase was accompanied by increases in estimated daily mean concentrations of particulate cadmium, chromium, copper, lead, nickel, and zinc. Based on the regression equations, the largest increase was for particulate zinc, which increased from about 2.6 micrograms per liter $(\mu \mathrm{g} / \mathrm{L})$ on December 23 to a peak of $71 \mu \mathrm{g} / \mathrm{L}$ on December 24. Particulate copper and lead also increased by similar amounts. The concentration of particulate chromium, which was less than $1 \mu \mathrm{g} / \mathrm{L}$ before the event, increased to a peak of $20.6 \mu \mathrm{g} / \mathrm{L}$. Particulate cadmium and nickel increased by smaller amounts compared with other constituents.

Downstream of the former Rockdale Pond monitoring station (01110500), daily mean streamflow increased from about $100 \mathrm{ft}^{3} / \mathrm{s}$ on December 23 2007, to about $325 \mathrm{ft}^{3} / \mathrm{s}$ on December 24, 2007, dropped to about $200 \mathrm{ft}^{3} / \mathrm{s}$ over the next 2 days, and remained between 200 and $250 \mathrm{ft}^{3} / \mathrm{s}$ for several days more (fig. 13B). Concentrations of trace elements also peaked on December 24 (zinc, $54.3 \mu \mathrm{g} / \mathrm{L}$; lead, $34.8 \mu \mathrm{g} / \mathrm{L}$; copper, $33.4 \mu \mathrm{g} / \mathrm{L}$; chromium, $10.2 \mu \mathrm{g} / \mathrm{L}$; nickel, $3.62 \mu \mathrm{g} / \mathrm{L}$; and cadmium, $1.8 \mu \mathrm{g} / \mathrm{L}$ ). Trace element concentrations fell off substantially by the next day (December 25) and continued to decline over the next few days. Concentrations of copper, lead, and zinc remained higher than the concentrations of cadmium, chromium, and nickel.

At the monitoring station upstream of Rice City Pond (01110530), daily mean streamflow increased from about
$100 \mathrm{ft}^{3} / \mathrm{s}$ on June 22, 2008, to almost $600 \mathrm{ft}^{3} / \mathrm{s}$ on June 24, 2008 and fell to less than $250 \mathrm{ft}^{3} / \mathrm{s}$ on June 27 (fig. 14A). Trace element concentrations also peaked on June 24 (zinc, $24.9 \mu \mathrm{g} / \mathrm{L}$; lead, $14.5 \mu \mathrm{g} / \mathrm{L}$; copper, $14.2 \mu \mathrm{g} / \mathrm{L}$; chromium, $5.19 \mu \mathrm{g} / \mathrm{L}$; nickel, $1.46 \mu \mathrm{g} / \mathrm{L}$; and cadmium, $0.629 \mu \mathrm{g} / \mathrm{L})$.

At the outlet of Rice City Pond at monitoring station 01110535, results presented a similar picture, with streamflow peaking on December 24, 2007 (fig. 14B). For the most part, streamflow ranged between about 100 and $150 \mathrm{ft}^{3} / \mathrm{s}$ for most of November and December; from December 23 to December 24, streamflow rose to more than $350 \mathrm{ft}^{3} / \mathrm{s}$. Concentrations of trace elements also peaked on December 24 (zinc, $43.7 \mu \mathrm{g} / \mathrm{L}$; lead, $24.1 \mu \mathrm{g} / \mathrm{L}$; copper, $23.0 \mu \mathrm{g} / \mathrm{L}$; chromium, $9.96 \mu \mathrm{g} / \mathrm{L}$; nickel, $2.89 \mu \mathrm{g} / \mathrm{L}$; and cadmium, $1.23 \mu \mathrm{g} / \mathrm{L}$ ).

At all monitoring stations, trace element concentrations decreased sharply as soon as the flow began to decrease. Particulate copper, lead, and zinc concentrations generally decreased sharply in the first 24 hours, then slowly continued toward previous levels. Particulate cadmium, chromium, and nickel concentrations returned almost to previous concentrations within about 24 hours, even though flows remained elevated.

\section{Changes in Constituent Loading Resulting From Sediment Resuspension}

In order to determine the mass of materials that may be resuspended as a result of storm runoff, estimated daily loads of suspended sediment and representative constituents of trace elements and nutrients, based on the regressions, were examined for two time periods at all four monitoring stations. The chemical constituents selected were chromium and phosphorus and the time periods were December 19, 2007, to January 1, 2008, and March 16 to April 4, 2008, which are periods with nearly complete datasets for all four monitoring stations.

From December 23 to 24, 2007, the load of chromium at the former Rockdale Pond upstream monitoring station (01110400) increased from less than $1 \mathrm{~kg} / \mathrm{d}$ to about $17 \mathrm{~kg} / \mathrm{d}$ (fig. 15A). Loads at the other monitoring stations increased to about half that amount. By December 27, chromium loads at all stations decreased to about double their initial values. The loads remained at about those levels for the remainder of the period at all stations.

During the March to April 2008 period, the largest chromium loads occurred at the monitoring station at the outlet to Rice City Pond (01110535), which is also the farthest downstream station in the resuspension study (fig. 15B); the lowest loads were at the former Rockdale Pond upstream station (01110400), the farthest upstream station. During the March to April 2008 period, streamflow in the river was about double the streamflow in December 2007 to January 2008.

Loads of particulate phosphorus were low (about 20 to $30 \mathrm{~kg} / \mathrm{d}$ ) at all four monitoring stations before the storm of December 23 to 24, 2007 (fig. 16A). Peak loads represented 20 - to 30 -fold increases compared with starting conditions. 


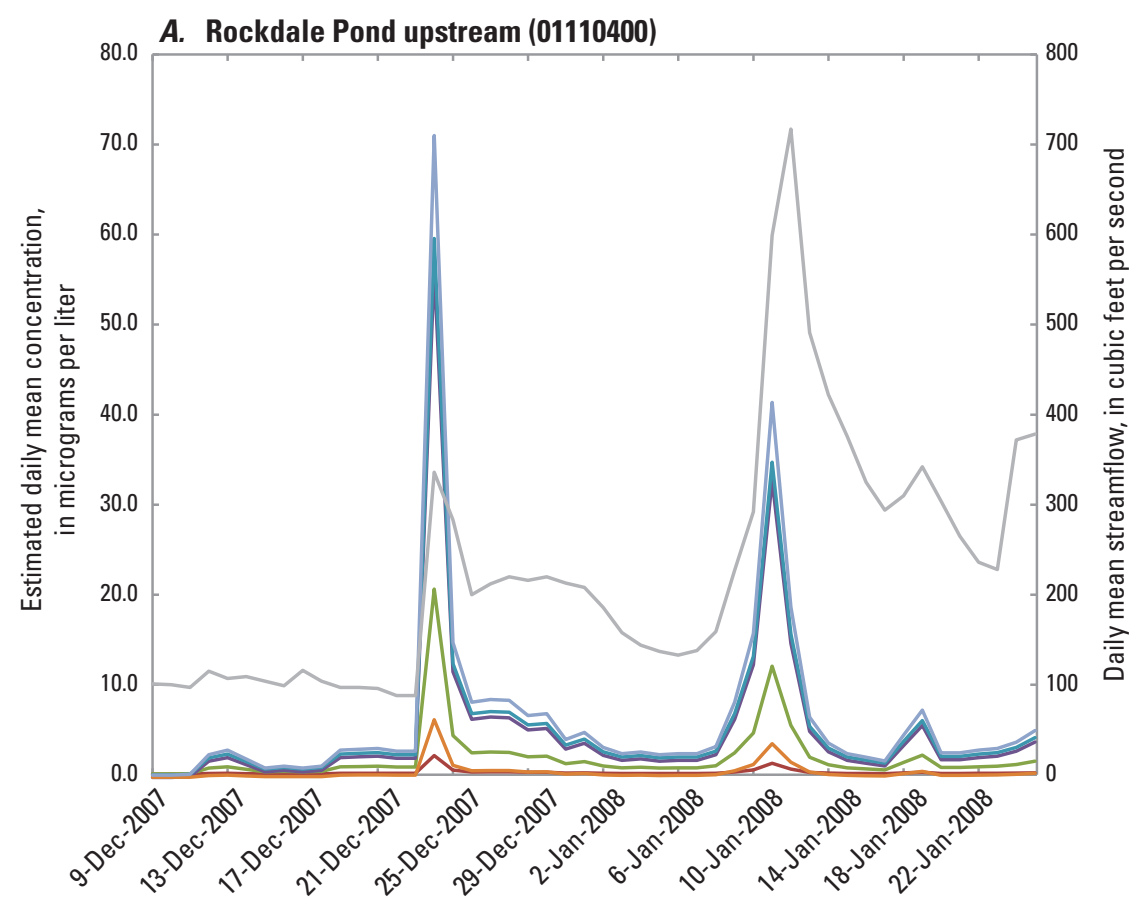

EXPLANATION

treamflow

Rockdale Pond upstream (01110400)

Estimated mean daily concentration, in micrograms per liter

\section{B. Rockdale Pond downstream (01110500)}

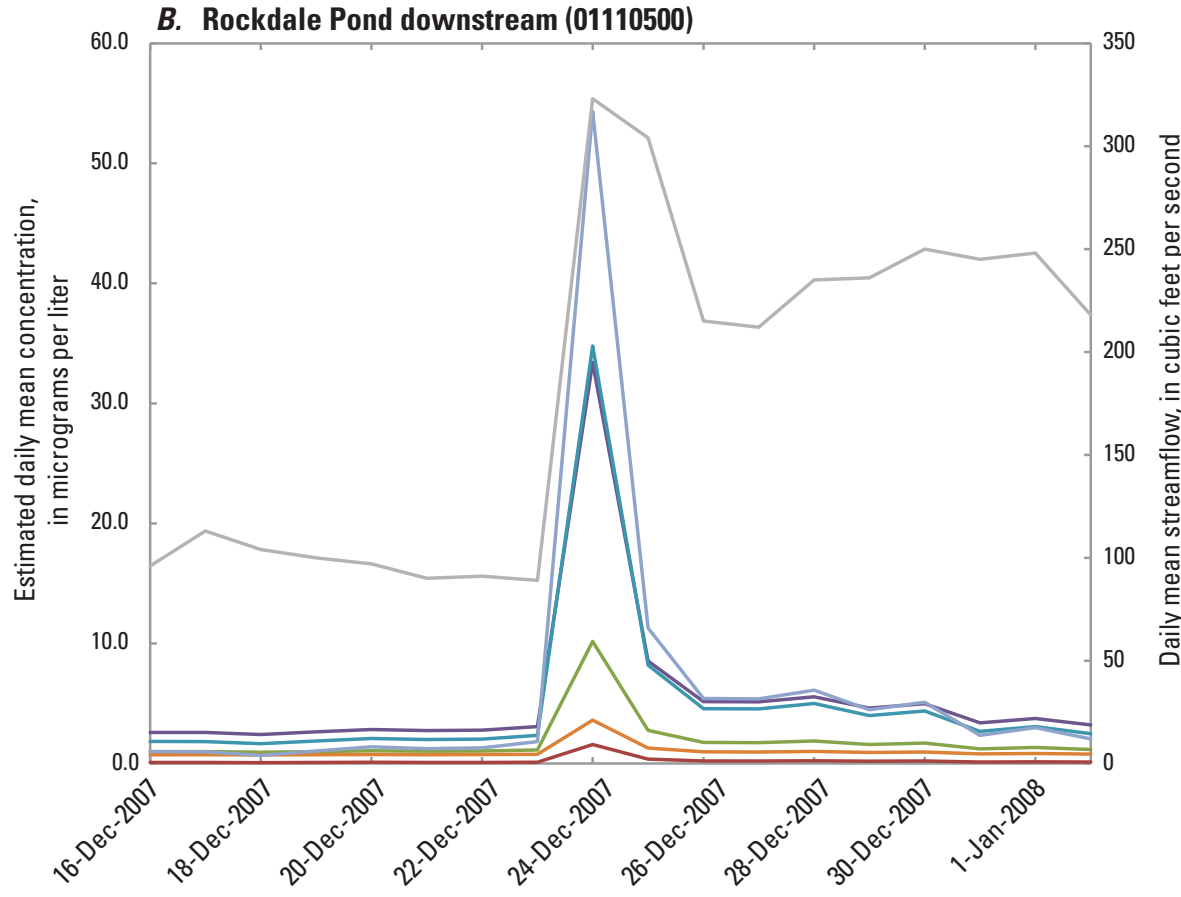

Particulate cadmium Particulate chromium Particulate copper Particulate lead Particulate nickel Particulate zinc

Figure 13. The effects of sediment resuspension on estimated particulate trace element concentrations at streamflow and water-quality monitoring stations $A$, upstream (station 01110400) and $B$, downstream (station 01110500) from the former Rockdale Pond impoundment on the Blackstone River, Massachusetts, during selected high-flow events in water year 2008. 


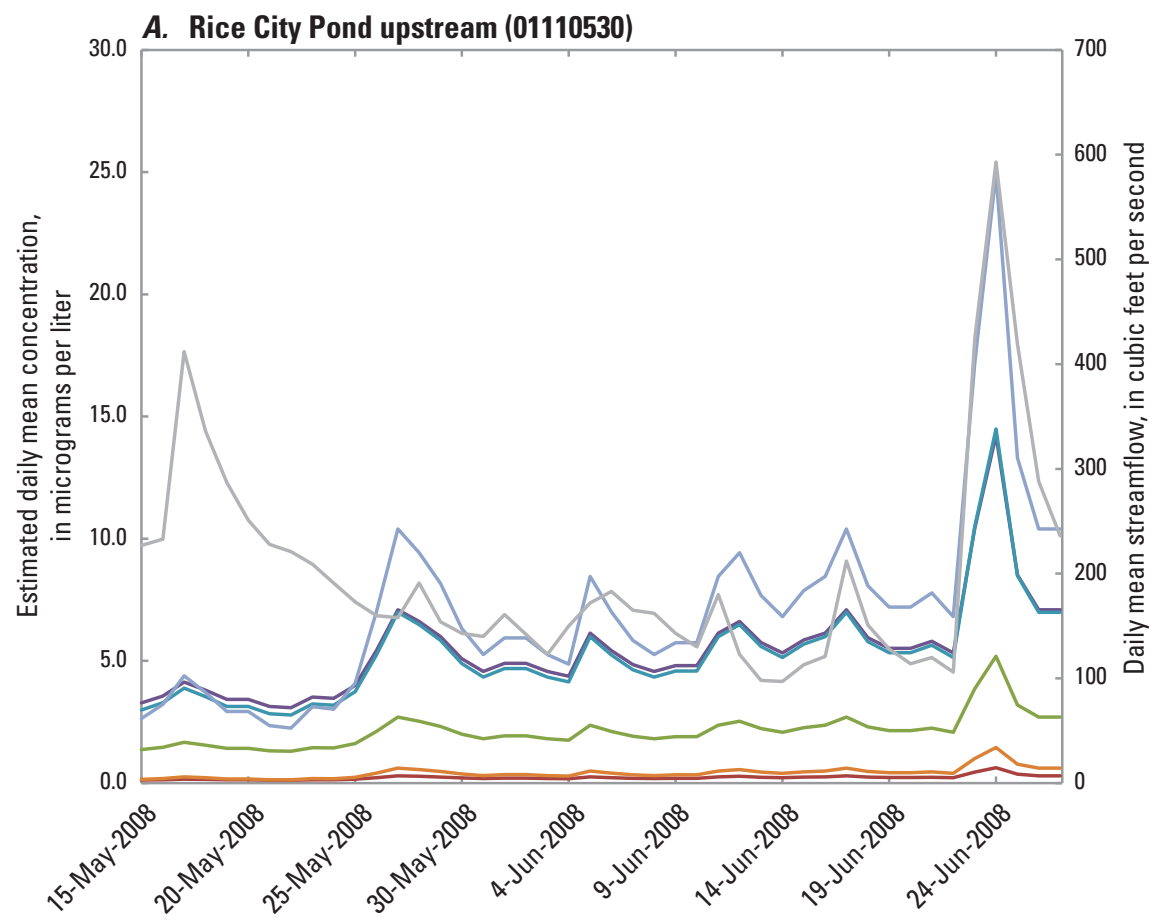

EXPLANATION

Streamflow

Rockdale Pond upstream (01110400)

Estimated mean daily concentration, in micrograms per liter

Particulate cadmium

$$
\text { D. }
$$

\section{B. Rice City Pond downstream (01110535)}

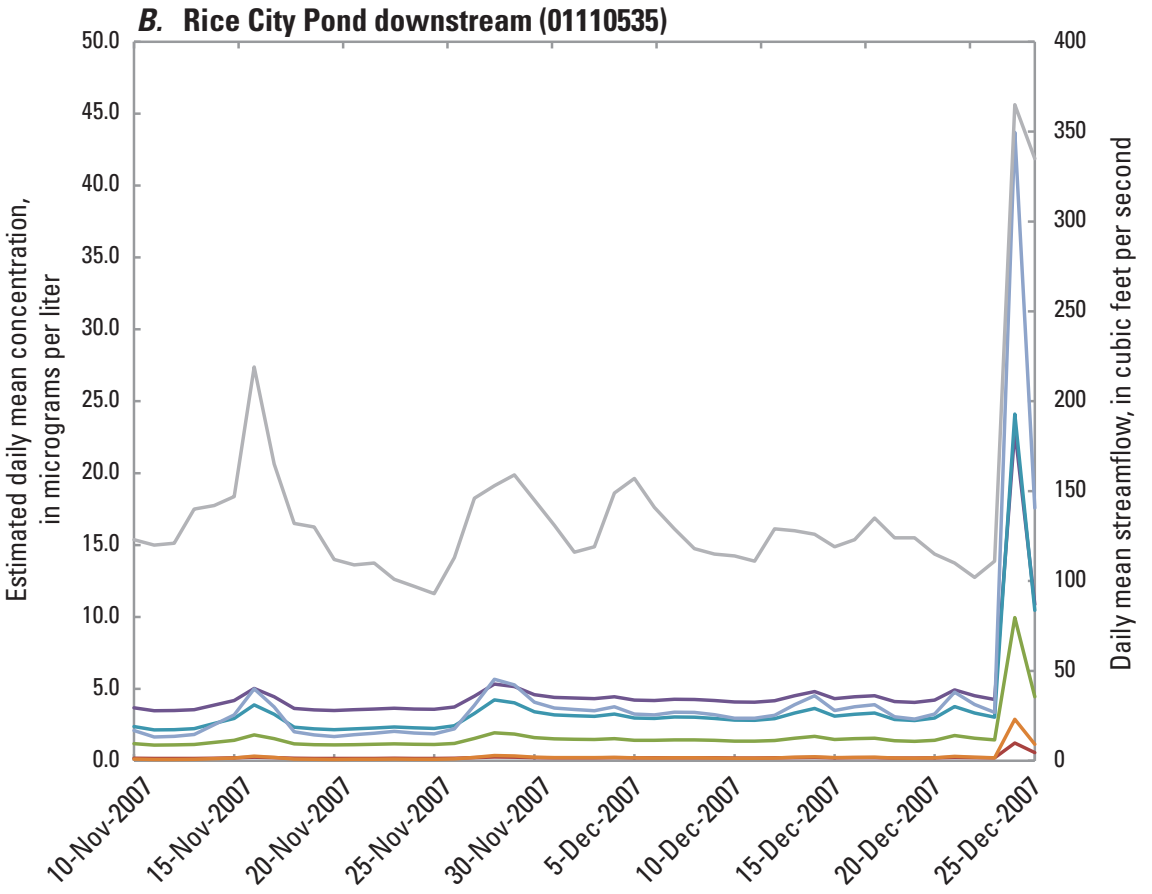

Particulate chromium

Particulate copper

Particulate lead

Particulate nickel

Particulate zinc

Figure 14. The effects of sediment resuspension on estimated particulate trace element concentrations at streamflow and water-quality monitoring stations $A$, upstream (station 01110530) and $B$, downstream (station 01110535) from the Rice City Pond impoundment on the Blackstone River, Massachusetts, impoundment during selected high-flow events in water year 2008. 


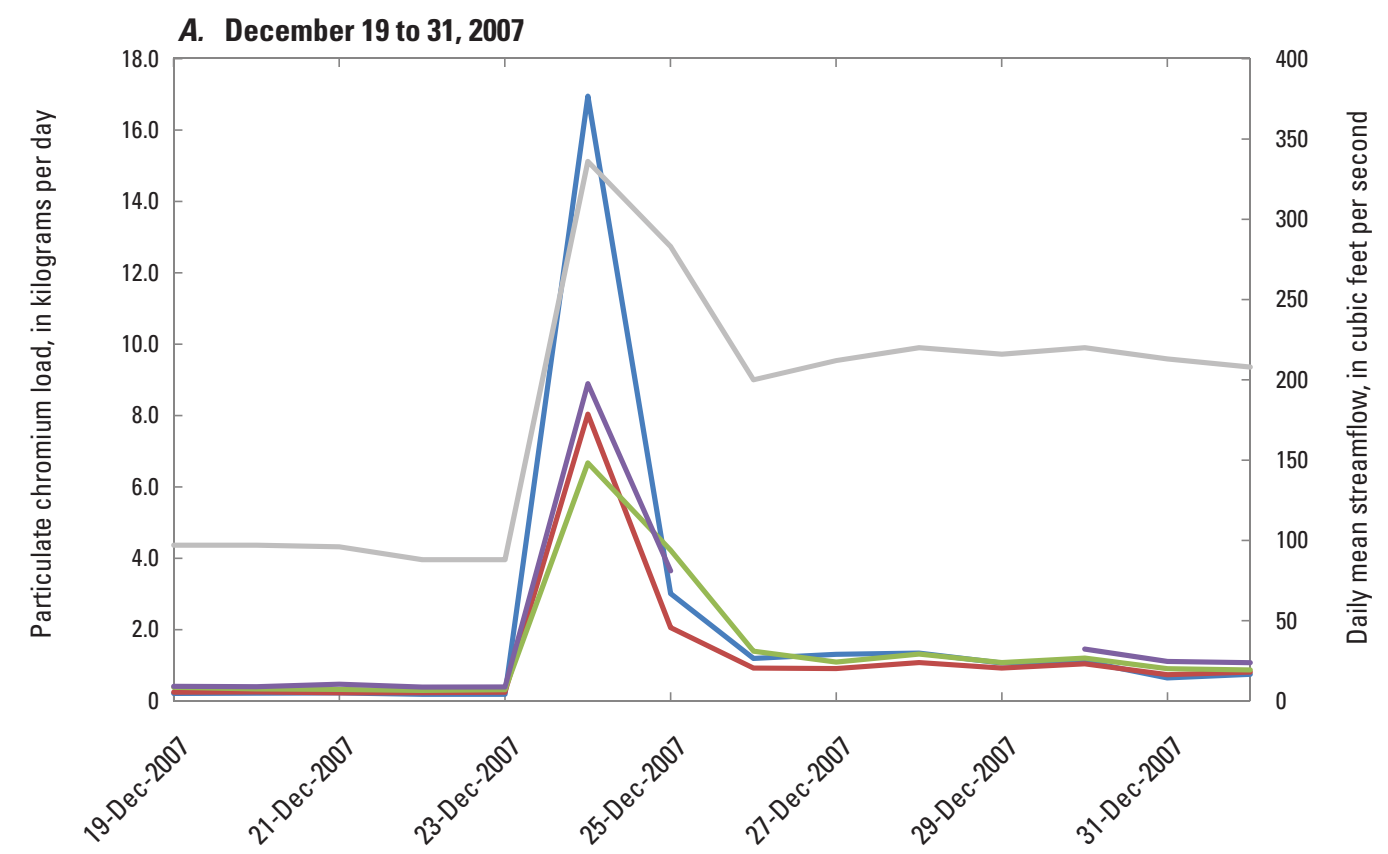

\section{B. March 16 to April 2, 2008}

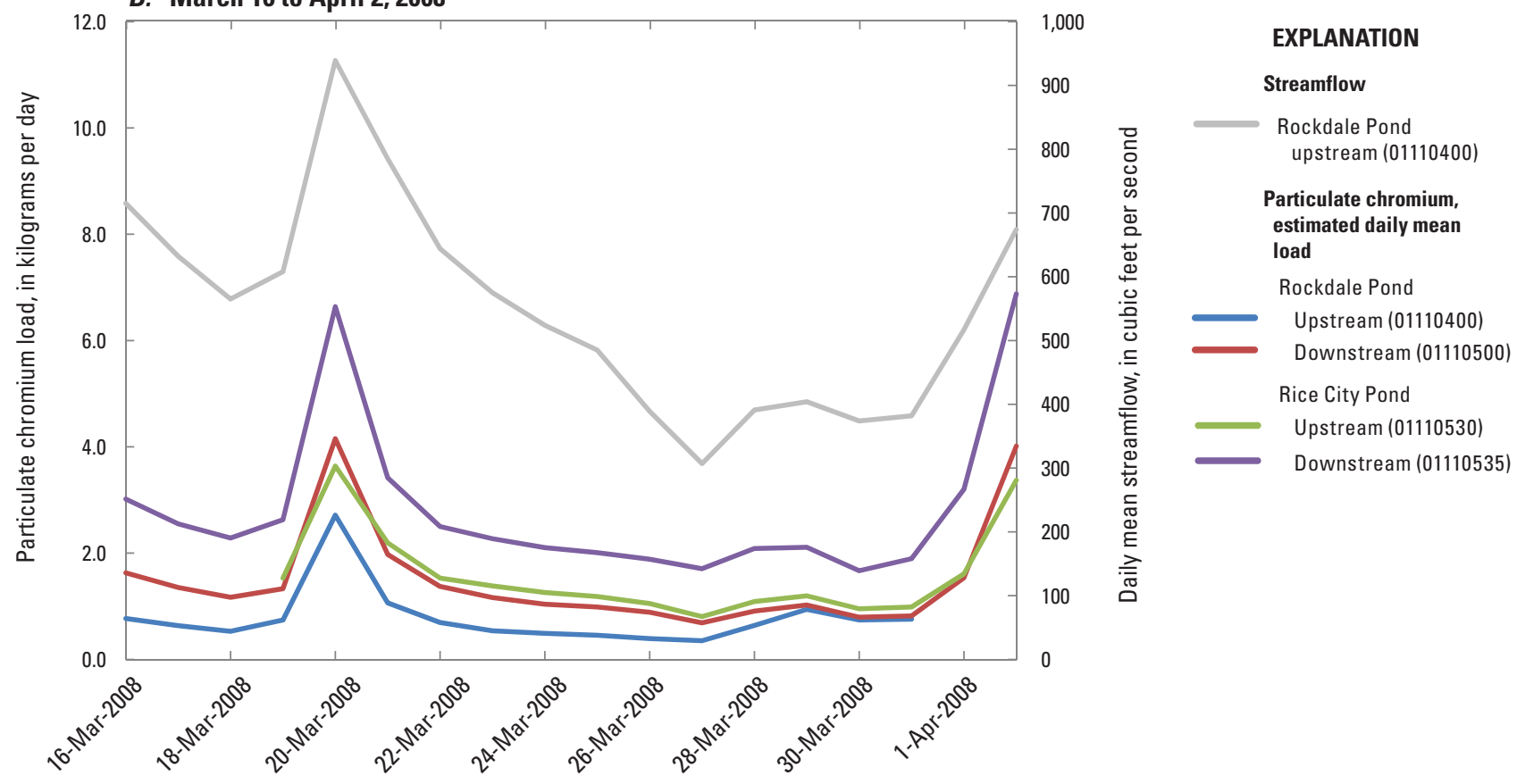

Figure 15. The effects of sediment resuspension on particulate chromium loads at four Blackstone River monitoring stations upstream and downstream from the former Rockdale Pond and Rice City Pond impoundments on the Blackstone River, Massachusetts, for A, December 19 to 31, 2007, and B, March 16 to April 2, 2008. 
A. December 19 to December 31, 2007

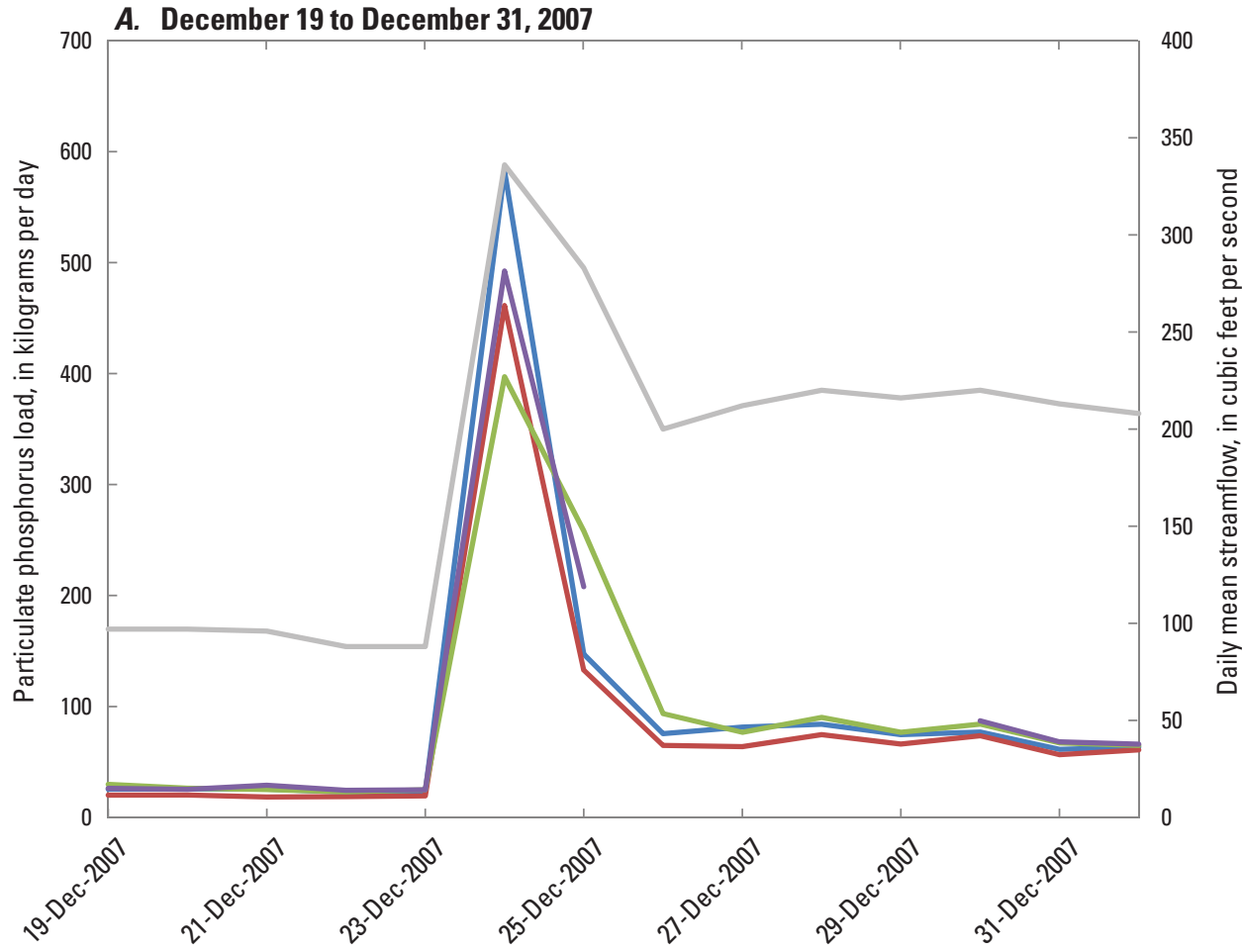

\section{B. March 16 to April 4, 2008}

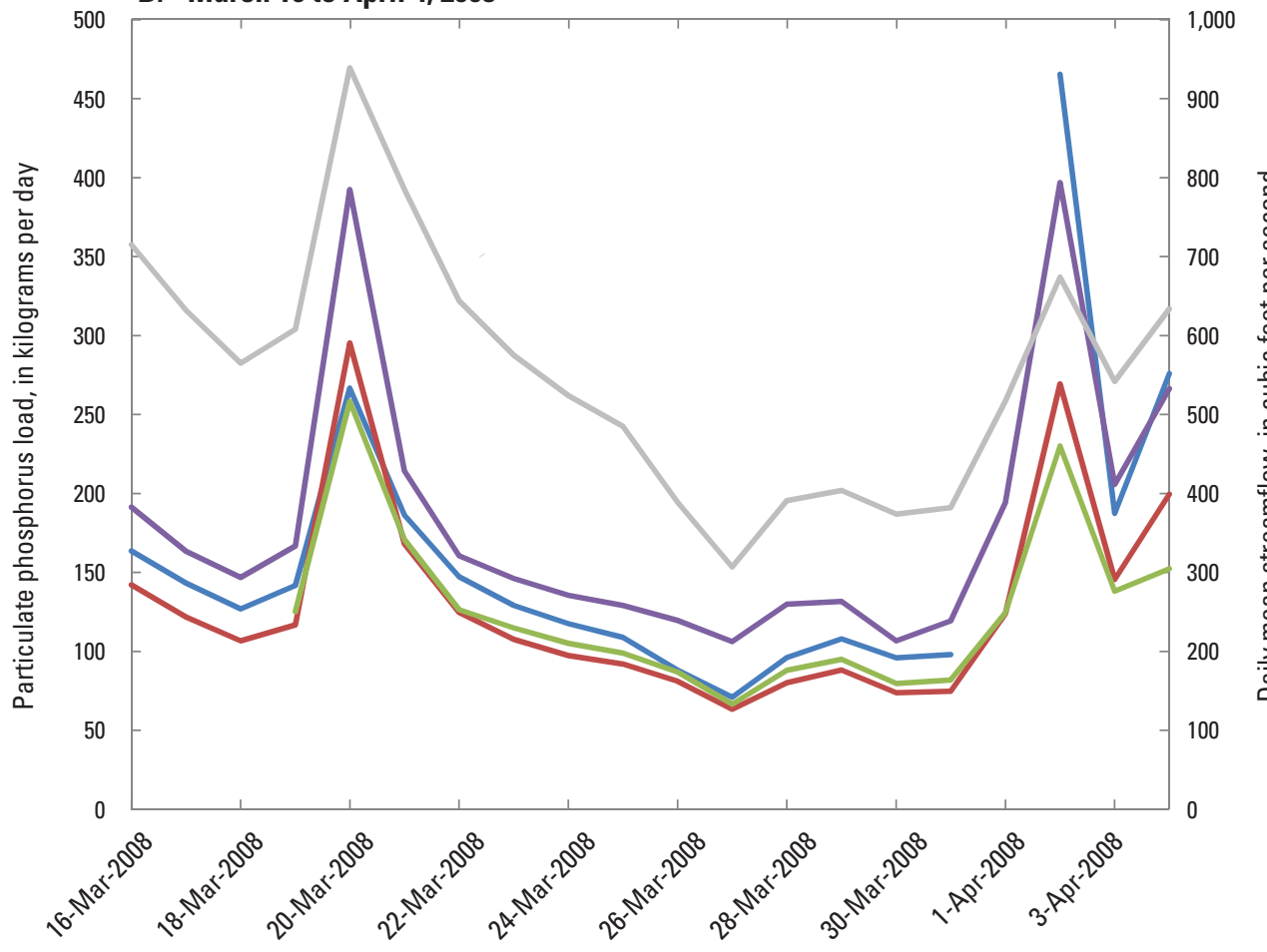

EXPLANATION

Streamflow

Rockdale Pond upstream (01110400)

Particulate phosphorus, estimated daily mean load

Rockdale Pond

Upstream (01110400)

Downstream (01110500)

Rice City Pond

Upstream (01110530)

Downstream (01110535)

Figure 16. The effects of sediment resuspension on particulate phosphorus loads at four Blackstone River monitoring stations upstream and downstream from the former Rockdale Pond and Rice City Pond impoundments on the Blackstone River, Massachusetts, for $A$, December 19 to 31, 2007, and B, March 16 to April 4, 2008. 
The largest maximum daily load was measured at the former Rockdale Pond upstream monitoring station (011110400). After the storm peak flow receded, loads at the three stations for which data were available decreased to about $50 \mathrm{~kg} / \mathrm{d}$ (fig. 16A).

For the first storm during the March to April 2008 period (March 19-20; fig. 16B), the total particulate phosphorus load was largest at the Rice City Pond outlet monitoring station (01110535; almost $400 \mathrm{~kg} / \mathrm{d}$ ). For the second storm (April 1-2, 2008), the load was largest at the former Rockdale Pond upstream monitoring station (01110400; more than $450 \mathrm{~kg} / \mathrm{d}$ ). Between the two storms, loads decreased to slightly less than their initial values at the start of the time period.

During the December 23 to 24, 2007, storm, peak suspended sediment loads ranged from about $48,000 \mathrm{~kg} / \mathrm{d}$ (Rice City pond upstream, station 01110530) to almost $80,000 \mathrm{~kg} / \mathrm{d}$ (the former Rockdale Pond upstream, station 01110400). Before the storm, the loads were in the range of 1,000 to $2,000 \mathrm{~kg} / \mathrm{d}$ (fig. 17A).

In the March to April 2008 period, initial suspended sediment loads were less than $10,000 \mathrm{~kg} / \mathrm{d}$ and increased to between about 20,000 kg/d (former Rockdale Pond upstream, station 01110400 ) and $35,000 \mathrm{~kg} / \mathrm{d}$ (Rice City Pond outlet, station 01110535) during the first storm (March 19 to 20, 2008) before returning to approximately the same loads as before the storms (fig. 17B). During the second storm (April 1 to 2, 2008), loads ranged from about $20,000 \mathrm{~kg} / \mathrm{d}$ at the Rice City Pond upstream station (01110530) to about 55,000 kg/d at the former Rockdale Pond upstream station (01110400).

Applying the regression equations relating turbidity to concentration at the four monitoring stations yields consistent results for particulate chromium, particulate phosphorus, and suspended sediment. During the December 2007 to January 2008 period, low-flow loads were approximately the same at all stations (figs. 15A, 16A, and 17A). During peaking storm flows, loads at the former Rockdale Pond upstream monitoring station (01110400) were largest, followed by monitoring stations at the Rice City Pond outlet (01110535), the former Rockdale Pond downstream (01110500), and Rice City Pond upstream (011110530).

During the March to April 2008 period, initial loads were not the same (figs. 15B, 16B, and 17B); initial loads for particulate chromium and phosphorus were greatest at the outlet from Rice City Pond, whereas those for suspended sediment were greatest at the upstream end of the former Rockdale Pond. Daily mean streamflows peaked on March 20, at which point all three constituent loads exhibited maximum values at the outlet to Rice City Pond (01110535). Between storms, constituent loads at all four monitoring stations decreased. When streamflows peaked again on April 2, loads for all three constituents were largest at the former Rockdale Pond upstream monitoring station (01110400).

\section{Effects of Flow on Changes in Constituent Loads During Passage Through Impoundments}

The role of river impoundments in promoting deposition and subsequent resuspension and transport of particulate contaminants was investigated by comparing relations between the magnitudes of maximum daily mean streamflows during high-flow events with changes in particulateconstituent loads during passage through the Rice City and the former Rockdale and impoundments. Figures 18 through 20 show differences between estimated loads at the stations bracketing the impoundments for periods of high flow during water year 2008, plotted against the corresponding maximum daily mean flows for the upstream monitoring stations (stations 01110400 and 01110530) for each impoundment. The examples illustrated in the figures include one particulate trace element (chromium), one particulate nutrient (phosphorus), and suspended sediment; however, other constituents exhibited similar behavior.

Most of the changes in particulate chromium loading during high-flow events in the former Rockdale Pond were negative (fig. 18A); that is, during most high-flow events, there was more particulate chromium entering than leaving the formerly impounded river reach, indicating that the reach was acting as a sink for particulate chromium. This effect was relatively independent of the magnitude of the flow. Exceptions occurred during two extremely high flow events in September 2008. On September 7 and again on September 27, daily mean flows reached 2,500 and $710 \mathrm{ft}^{3} / \mathrm{s}$, respectively. These were among the highest flows recorded during the water year 2008 monitoring period. Both of these events were accompanied by exceptionally large increases in the estimated maximum loads at the upstream end of the study reach $(94,700 \mathrm{~kg} / \mathrm{d}$ on September 7 and $54,200 \mathrm{~kg} / \mathrm{d}$ on September 27). In both cases, however, these large initial loads of particulate material quickly settled out of the water column so that the chromium load that exited the formerly impounded area was greatly reduced.

In contrast, there was a strong, positive relation between the change in chromium load and peak flow in Rice City Pond (fig. 18B), indicating that the intact impoundment was acting primarily as a source for particulate chromium. Changes in the estimated chromium loads ranged from less than $0.6 \mathrm{~kg} / \mathrm{d}$ at peak flows less than $300 \mathrm{ft}^{3} / \mathrm{s}$ to more than $3.4 \mathrm{~kg} / \mathrm{d}$ at a peak flow of $1,310 \mathrm{ft}^{3} / \mathrm{s}$. One exception to this pattern occurred on March 9, 2008, at the highest daily mean flow $\left(2,240 \mathrm{ft}^{3} / \mathrm{s}\right)$ recorded during the study period at the Rice City Pond upstream station (01110530). This peak followed a monthlong period when flows tended to be larger than $1,000 \mathrm{ft}^{3} / \mathrm{s}$ and never lower than $500 \mathrm{ft}^{3} / \mathrm{s}$. The estimated chromium load at the upstream monitoring station $(26.6 \mathrm{~kg} / \mathrm{d})$ was by far the largest encountered during the study period and was very similar to that at the downstream monitoring station $(25.8 \mathrm{~kg} / \mathrm{d})$, indicating that most of the extremely large particulate load was deposited within the impoundment. In general, however, the 
A. December 19, 2007 to January 1, 2008

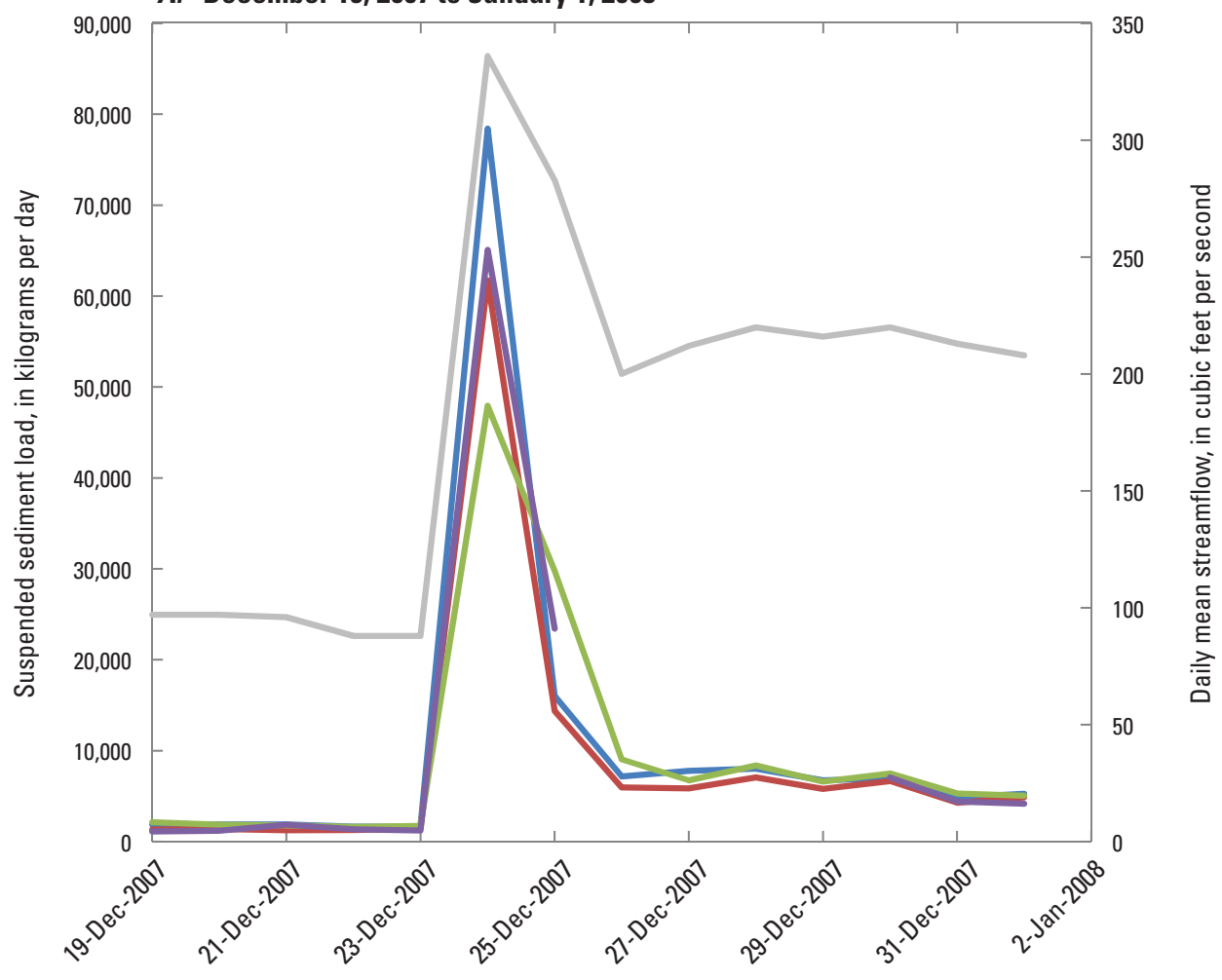

\section{B. March 16 to April 4, 2008}

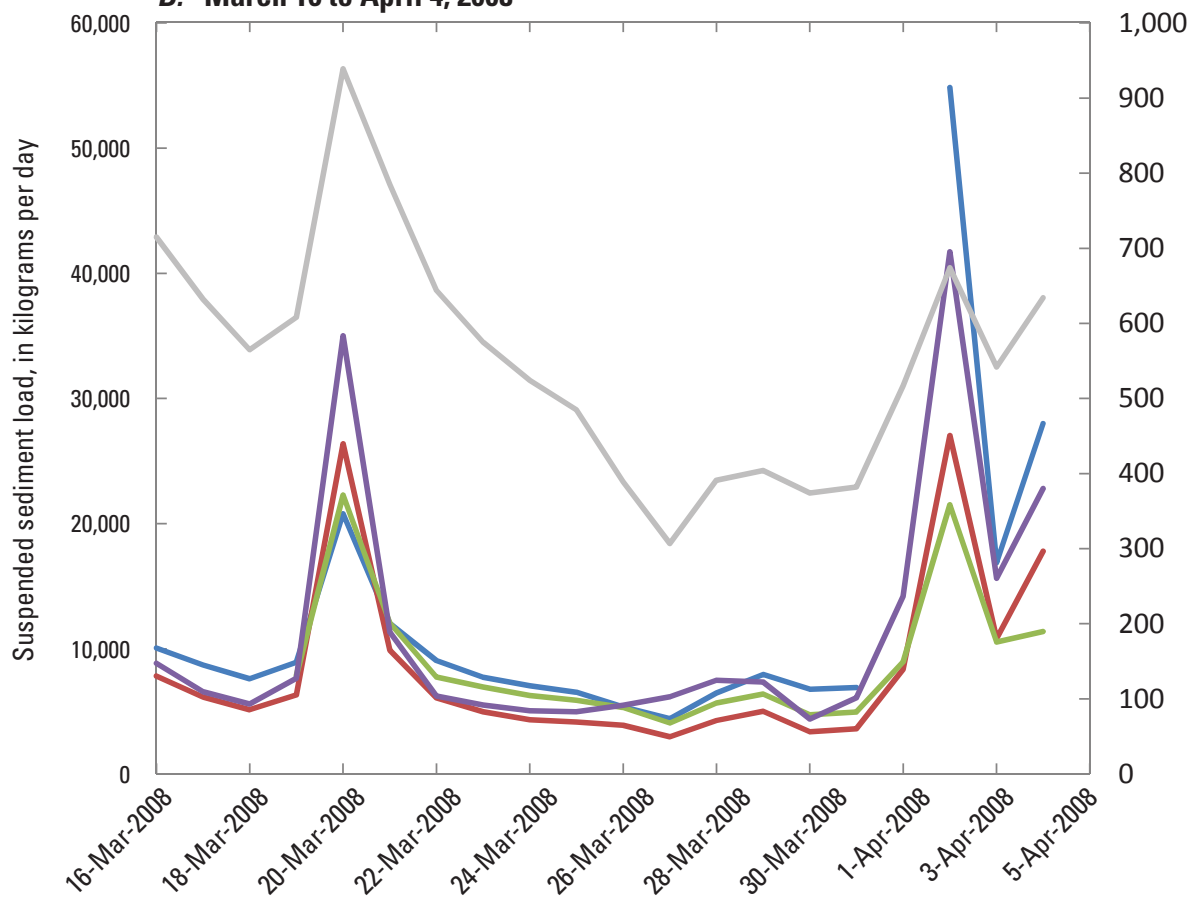

EXPLANATION

Streamflow

Rockdale Pond upstream (01110400)

Suspended sediment, estimated daily mean load

Rockdale Pond

Upstream (01110400)

Downstream (01110500) Rice City Pond Upstream (01110530) Downstream (01110535)

Figure 17. The effects of sediment resuspension on suspended sediment loads at four Blackstone River monitoring stations upstream and downstream from the former Rockdale Pond and Rice City Pond impoundments on the Blackstone River, Massachusetts, for $A$, December 19, 2007, to January 1, 2008, and B, March 16 to April 4, 2008. 


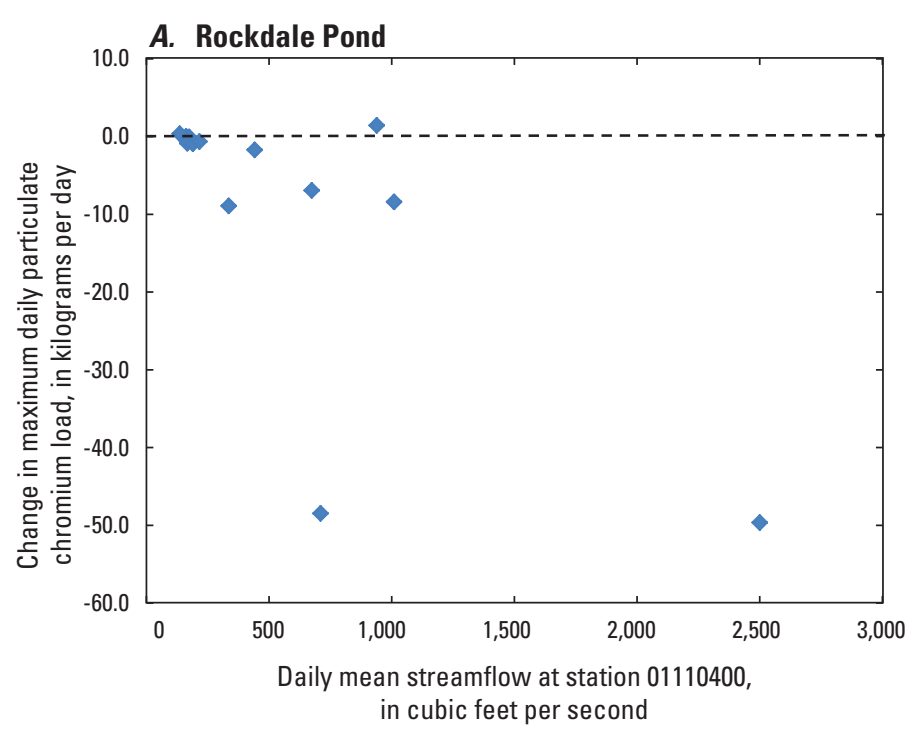

B. Rice City Pond

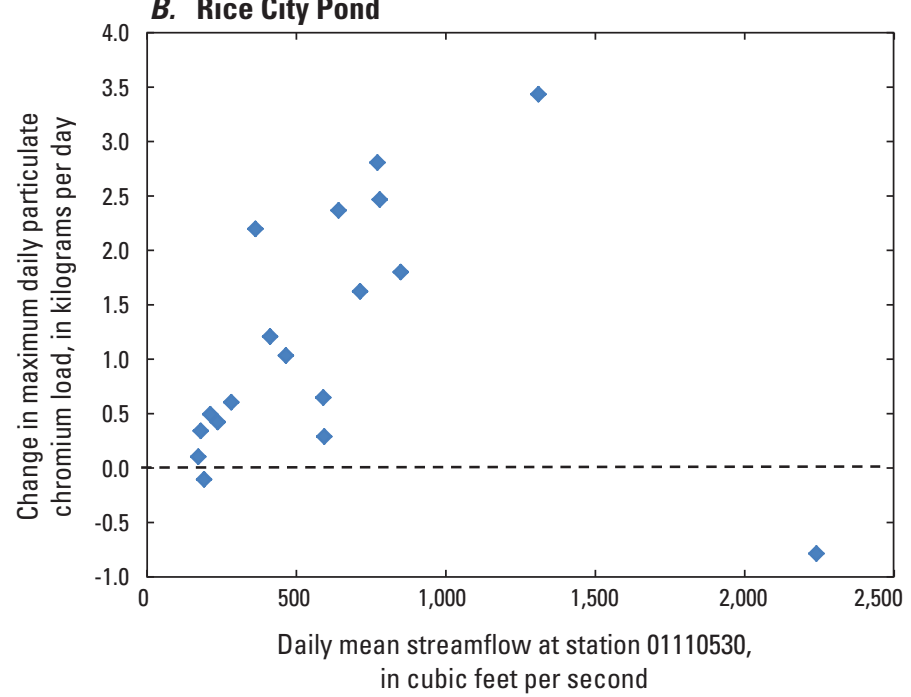

Figure 18. The effects of streamflow on changes in maximum daily particulate chromium loads in the $A$, former Rockdale Pond and $B$, Rice City Pond impoundments on the Blackstone River, Massachusetts, during high-flow events in water year 2008. intact Rice City impoundment acted as a source of particulate chromium to the river.

Similar responses were observed for the relation between maximum daily mean streamflow and resuspension of particulate phosphorus (fig. 19A). There was very little net transport of particulate phosphorus out of the formerly impounded section of Rockdale Pond, regardless of the level of flow at the upstream monitoring station. Either there was no measureable change in phosphorus load in response to the increased flow or there was less particulate phosphorus leaving the reach than entering. In Rice City Pond, on the other hand, there was generally a direct positive relation between the maximum daily mean flow and the amount of particulate phosphorus that was resuspended and transported downstream (fig. 19B). The change in particulate phosphorus load ranged from about $17 \mathrm{~kg} / \mathrm{d}$ at the lowest flows associated with observed high-flow events to about $114 \mathrm{~kg} / \mathrm{d}$ at the highest flows. Again, the extremely high peak daily mean flow that occurred on March 9, 2008, resulted in a net decrease in particulate phosphorus load, presumably because most of the sediment deposits had already been scoured by previous highflow events.

The effect of flow on suspended sediment was similar to that of other particulate contaminants, that is, no change or a loss during transport through the former Rockdale Pond reach and increases in direct proportion to flow during transport through Rice City Pond (fig. 20). Suspended sediment increased during transport through Rice City Pond, with changes of less than $1,000 \mathrm{~kg} / \mathrm{d}$ at the lowest recorded maximum flows to more than $20,000 \mathrm{~kg} / \mathrm{d}$ at a maximum flow of $1,310 \mathrm{ft}^{3} / \mathrm{s}$.

The data presented in this report suggest that Blackstone River impoundments can be substantial sources of particulate contaminants, but that once dams are breached, there is little opportunity for accumulation of sediment and not much evidence of substantial downstream transport. The hypothesis that contaminated sediment deposits upstream from the site of the former Rockdale Mill Pond Dam might be subject to scouring and transport during high-flow events was not supported in this study. It is also possible that much of the contaminated sediment deposited in the former Rockdale Pond before the dam was breached had already been removed from scouring associated with previous storm events. Rice City Pond, on the other hand, appears to be a site of accumulation and settling of particulate contaminants during periods of low flow, and these deposits are mobilized during high-flow events and transported downstream. 

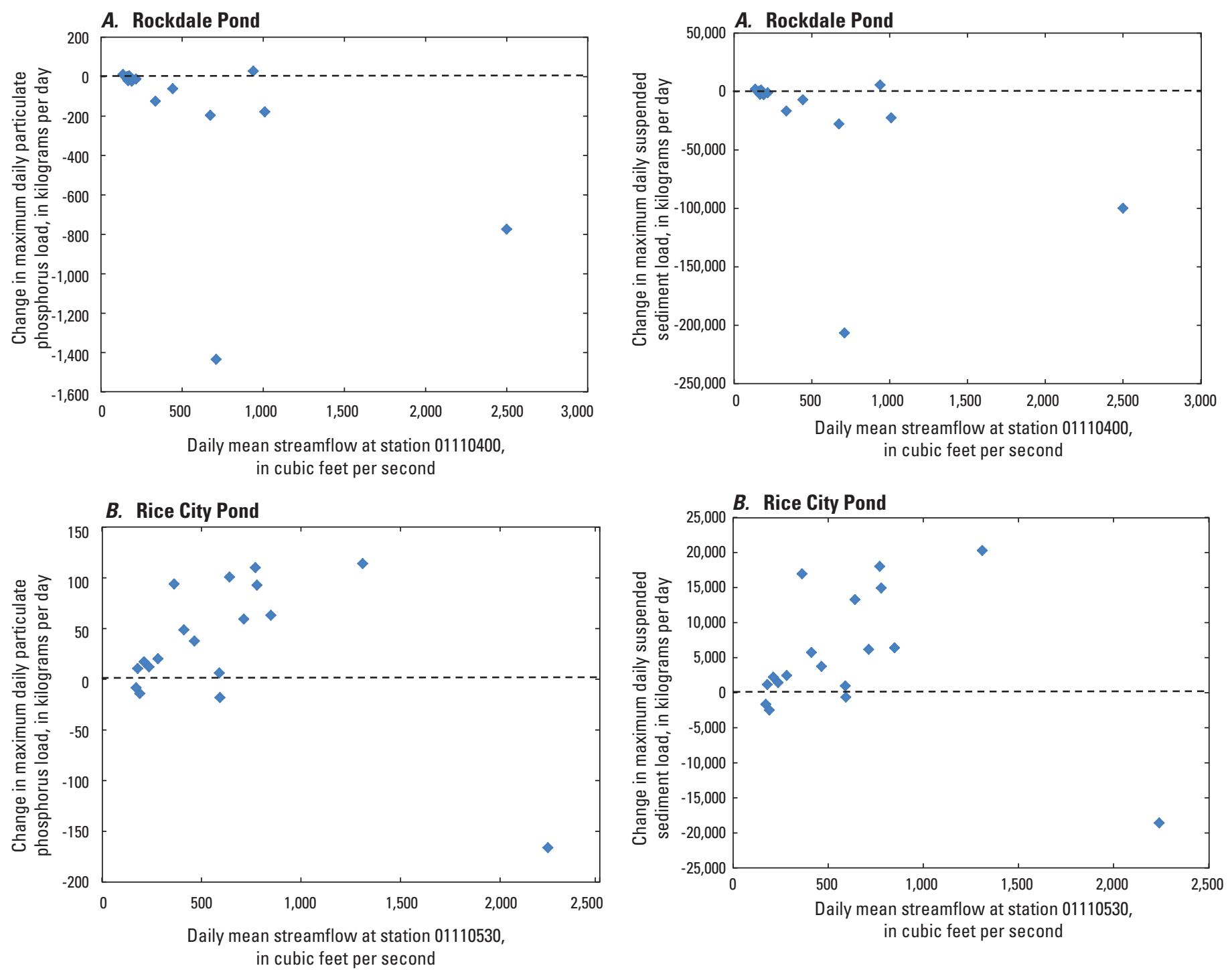

Figure 19. The effects of streamflow on changes in maximum daily particulate phosphorus loads in the $A$, former Rockdale Pond and $B$, Rice City Pond impoundments on the Blackstone River, Massachusetts, during high-flow events in water year 2008.

Figure 20. The effects of streamflow on changes in maximum daily suspended sediment loads in the $A$, former Rockdale Pond and $B$, Rice City Pond impoundments on the Blackstone River, Massachusetts, during high-flow events in water year 2008. 


\section{Summary}

The Blackstone River Basin has a long history of contamination, dating back to the industrial revolution. Improved infrastructure and wastewater treatment have resulted in improved water quality, but the river's water quality is still [2015] categorized as impaired along its entire length. Concerns about continuing water-quality degradation and potential effects on Narragansett Bay in Rhode Island, into which the river drains, prompted a cooperative study of contaminant loads in the river by the U.S. Geological Survey and the Massachusetts Department of Environmental Protection.

The loads of nutrients, suspended sediment, and trace elements were estimated at monitoring stations along the Blackstone River and selected tributaries in an effort to understand the distribution and sources of these constituents in the river basin. The loads of these constituents were monitored in the Massachusetts segment of the basin from 2007 to 2009 for nutrients and suspended sediment and from 2007 to 2008 for trace elements. One objective of the study was to monitor the loads of nitrogen and other constituents leaving Massachusetts and entering Rhode Island via the Blackstone River; these loads were estimated on an annual basis for water years 2008 and 2009. The effects of hydrologic conditions and the net attenuation of nitrogen loads were also investigated for loads in the Massachusetts segment of the basin. Finally, the extent and potential effects of sediment resuspension on contaminant loads were evaluated by analyzing concentrations of nutrients, suspended sediment, and trace elements and turbidity at monitoring stations upstream and downstream from two Blackstone River impoundments-Rice City Pond and the former Rockdale Pond (a breached impoundment). Data for the resuspension study were collected primarily in 2008 .

Loads of nutrients, suspended sediment, and trace elements (where collected) were estimated from flowproportional, composite water-quality samples that were collected over 2-week periods. These samples were collected at six stations on the main stem Blackstone River, at monitoring stations on three tributaries - the Quinsigamond, Mumford, and West Rivers - and at four wastewater treatment plants in the Massachusetts segment of the basin during 2007 to 2009. Flow-proportional, 2-week composite samples were collected at an additional station near the mouth of the Blackstone River in Pawtucket, Rhode Island, in parts of 2008 and 2009.

Total nitrogen loads are partly based on concentrations of total dissolved nitrogen for part or all of some sampling periods at some stations. This approach was used to address discrepancies between analytical results for total nitrogen and total dissolved nitrogen in many of the composite samples. The approach likely underestimated the total nitrogen loads calculated based on these samples. However, use of these estimates is not expected to greatly affect study findings because they are most frequently used for samples from in tributaries and at the most-upstream Blackstone River station (where loads are relatively small compared with main stem loads) and for samples that represent relatively small fractions of total streamflow during the sampling period.

Loads of total nitrogen along the Blackstone River in Massachusetts showed a similar general pattern during all sampling periods monitored in the study: relatively low total nitrogen loads at the farthest upstream monitoring station in Millbury, Massachusetts (typically less than 430 kilograms per day $[\mathrm{kg} / \mathrm{d}]$ ); a 5- to 10 -fold increase in load downstream of the Upper Blackstone Water Pollution Control Abatement District (UBWPAD) wastewater treatment plant on the river in Millbury; then, total nitrogen that remained elevated (typically about 1,000 to $3,000 \mathrm{~kg} / \mathrm{d}$ ) but varied from the Blackstone River Millbury upstream station to the Massachusetts-Rhode Island border near the Blackstone River Millville station. The tributaries and wastewater treatment plants other than the UBWPAD rarely contributed more than a small fraction of the loads observed at the main stem monitoring stations.

Changes in nitrogen loads along the river were investigated by analyzing relations with hydrologic conditions, and changes in net nitrogen load among consecutive monitoring stations along the river. Total nitrogen loads varied with hydrologic condition; the highest loads were observed during sampling periods when the contribution of base flow was less than the runoff component of streamflow. During these sampling periods, loads of total nitrogen from the UBWPAD wastewater discharge also were high, but loads from the UBWPAD also constituted smaller fractions of the total nitrogen loads in the river. Nitrogen attenuation may have occurred during some of the sampling periods as indicated by net changes in total nitrogen load between consecutive monitoring stations, especially in the 10.8-mile (mi) reach of the Blackstone River between the South Grafton and Uxbridge monitoring stations. Total nitrogen loads at the downstream end of this reach were lower than the nitrogen load at the upstream end of the reach during most of the sampling periods.

Loads of total phosphorus along the Blackstone River in Massachusetts showed a general pattern similar to that of nitrogen: relatively low total phosphorus loads at the farthest upstream monitoring station in Millbury (typically less than $37 \mathrm{~kg} / \mathrm{d}$ ); a 6- to 15 -fold increase in load downstream of the UBWPAD; then, total phosphorus loads that were relatively high (typically about 100 to $370 \mathrm{~kg} / \mathrm{d}$ ) but varied from the Blackstone River Millbury upstream station to the Massachusetts-Rhode Island border. Total phosphorus loads at the UBWPAD were less in 2009 (typically near $100 \mathrm{~kg} / \mathrm{d}$ ) than in 2007 and 2008 (mostly near $200 \mathrm{~kg} / \mathrm{d}$ ). Contributions of total phosphorus load from the tributaries and wastewater treatment plants, as with nitrogen, were only small fraction of the loads observed at the main stem monitoring stations.

Loads of suspended sediment also were substantially larger in the main stem river than in tributaries during most sampling periods. Tributary loads rarely exceeded $1,000 \mathrm{~kg} / \mathrm{d}$, whereas median loads of suspended sediment at main stem stations ranged from $3,160 \mathrm{~kg} / \mathrm{d}$ to more than $10,000 \mathrm{~kg} / \mathrm{d}$. Suspended sediment was not measured in wastewater 
treatment plant samples. Very large loads of suspended sediment (more than 100,000 kg/d) from the West River during several sampling periods may have been associated with floodcontrol operations at a dam on this tributary.

The estimated annual load of total nitrogen in the Blackstone River at the Millville station, about $1.3 \mathrm{mi}$ upstream from the Massachusetts-Rhode Island Border, was 936,000 kilograms (kg; 2,600 kg/d) in water year 2008 and $878,000 \mathrm{~kg}(2,400 \mathrm{~kg} / \mathrm{d})$ in water year 2009 . The estimated annual load of total phosphorus at the Blackstone River Millville station was 81,400 kg in water year $2008(223 \mathrm{~kg} / \mathrm{d})$ and $80,900 \mathrm{~kg}(222 \mathrm{~kg} / \mathrm{d})$ in water year 2009 . The estimated annual load of suspended sediment was 4,940,000 kg $(13,600 \mathrm{~kg} / \mathrm{d})$ in water year 2008 and 7,040,000 kg $(19,300 \mathrm{~kg} / \mathrm{d})$ in water year 2009 ; the higher load in water year 2009 likely reflects the larger streamflows and several large storms in 2009. Loads of total nitrogen, total phosphorus, and trace elements were almost always lower in the Blackstone River at the Millville station than near the mouth of the river at the Pawtucket monitoring station when loads were monitored at both stations in the latter part of water year 2008 and in water year 2009; loads of suspended sediment at the Millville and Pawtucket stations varied in about the same range, but were usually lower at the Pawtucket station than at the Millville station.

Analysis of the representative constituents total phosphorus, total chromium, and suspended sediment upstream and downstream of impoundments indicated that the existing impoundments, such as Rice City Pond, can be sources of particulate contaminant loads in the Blackstone River. Loads of particulate phosphorus, particulate chromium, and suspended sediment were consistently higher downstream from Rice City Pond than upstream during high-flow events, and there was a positive, linear relation between streamflow and changes in these constituents from upstream to downstream of the impoundment. Thus, particulate contaminants were mobilized from Rice City Pond during high-flow events and transported downstream. In contrast, downstream loads of particulate phosphorus, particulate chromium, and suspended sediment were generally lower than or equal to upstream loads for the former Rockdale Pond impoundment. The dam at the former Rockdale Pond was breached in the late 1960s, and sediments associated with the former impoundment did not appear to be mobilized during the high-flow events monitored during the study detailed in this report.

\section{References Cited}

Anderson, C.W., 2005, Turbidity (ver. 2.1), sec. 6.7 of Field measurements: U.S. Geological Survey Techniques of Water-Resources Investigations, book 9, chap. A6, accessed February 20, 2015, at http://pubs.water.usgs.gov/twri9A6/.
Barbaro, J.R., and Zarriello, P.J., 2007, A precipitation-runoff model for the Blackstone River Basin, Massachusetts and Rhode Island: U.S. Geological Survey Scientific Investigations Report 2006-5213, 95 p. [Also available at http://pubs.usgs.gov/sir/2006/5213/.]

Fishman, M.J., ed., 1993, Methods of analysis by the U.S. Geological Survey National Water Quality LaboratoryDetermination of inorganic and organic constituents in water and fluvial sediments: U.S. Geological Survey Open-File Report 93-125, 217 p. [Also available at http://pubs.er.usgs.gov/publication/ofr93125.]

Fishman, M.J., and Friedman, L.C., 1989, Methods for determination of inorganic substances in water and fluvial sediments: U.S. Geological Survey Techniques of WaterResources Investigations, book 5, chap. A1, 545 p. [Also available at http://pubs.usgs.gov/twri/twri5-a1/.]

Garbarino, J.R., and Struzeski, T.M., 1998, Methods of analysis by the U.S. Geological Survey National Water Quality Laboratory-Determination of elements in whole-water digests using inductively coupled plasma-optical emission spectrometry and inductively coupled plasma-mass spectrometry: U.S. Geological Survey Open-File Report 98-165, 101 p. [Also available at http://nwql.usgs.gov/ OFR-98-165.shtml.]

Izbicki, J.A., 1993, Water resources of the Blackstone River Basin, Massachusetts: U.S. Geological Survey WaterResources Investigations Report 93-4167, 115 p. [Also available at http://pubs.er.usgs.gov/publication/wri934167.]

Kennedy, E.J., 1984, Discharge ratings at gaging stations: U.S. Geological Survey Techniques of Water-Resources Investigations, book 3, chap. A10, 59 p. [Also available at http://pubs.usgs.gov/twri/twri3-a10/.]

Kerr, Meg, 1990, The Blackstone River: Narragansett, Rhode Island Sea Grant fact sheet, 1 p., accessed May 15, 2013, at http://seagrant.gso.uri.edu/factsheets/blackstone_river.html. [Publication removed from Web site at time of publication.]

Lim, K.J., Engel, B.A., Tang, Zhenxu, Choi, Joongdae, Kim, Ki-Sung, Muthukrishnan, Suresh, and Tripathy, Dibyajyoti, 2005, Automated web GIS based hydrograph analysis tool, WHAT: Journal of the American Water Resources Association, v. 41, no. 6, p. 1407-1416. [Also available at http://dx.doi.org/10.1111/j.1752-1688.2005.tb03808.x.]

Massachusetts Department of Environmental Protection, 2010, Blackstone River watershed-2003-2007 water quality assessment report: Worcester, Mass., Massachusetts Department of Environmental Protection 51-AC-3, 216 p., accessed October 9, 2012, at http://www.mass. gov/dep/water/resources/wqassess.htm\#wqar. [Report moved to http:/www.mass.gov/eea/docs/dep/water/ resources/3baapp/51wqar10.pdf at time of publication.] 
Massachusetts Executive Office of Energy and Environmental Affairs, 2015, Interactive mapping of the 2012 integrated list of waters: Massachusetts Executive Office of Energy and Environmental Affairs Web page, accessed February 23, 2015, at http:/www.mass.gov/eea/agencies/massdep/water/ watersheds/2012-integrated-list-of-waters.html.

McGinn, J.M., 1981, A sediment control plan for the Blackstone River: Boston, Massachusetts Department of Environmental Quality Engineering, 238 p.

Métadier, M., and Bertrand-Krajewski, J.-L., 2012, The use of long-term on-line turbidity measurements for the calculation of urban stormwater pollutant concentrations, loads, pollutographs and intra-event fluxes: Water Resources, v. 46 , no. 20 , p. 6836-6856.

Parker, G.W., Breault, R.F., Waite, A.M., and Hartman, Elaine, 2011, Time of travel and dispersion of a dye plume in the Blackstone River, Massachusetts and Rhode Island, 2009: U.S. Geological Survey Open-File Report 2011-1284, 13 p. [Report is available by request only; information available at http://pubs.usgs.gov/of/2011/1284/.]

Patton, C.J., and Kryskalla, J.R., 2003, Methods of analysis by the U.S. Geological Survey National Water Quality Laboratory_Evaluation of alkaline persulfate digestion as an alternative to Kjeldahl digestion for determination of total and dissolved nitrogen and phosphorus in water: U.S. Geological Survey Water-Resources Investigations Report 03-4174, 33 p. [Also available at http:/nwql.usgs.gov/ WRIR-03-4174.shtml.]

Rantz, S.E., and others, 1982, Measurement and computation of streamflow: U.S. Geological Survey Water-Supply Paper 2175, 631 p. [Also available at http://pubs.usgs.gov/wsp/ wsp2175/.]

Rhode Island Department of Environmental Management, 1998, Narragansett Bay water quality - Status and trends: Providence, Rhode Island Department of Environmental Management, July, accessed September 12, 2014, at http:/www.dem.ri.gov/programs/benviron/water/quality/ pdf/narbqual.pdf.

Rus, D.L., Patton, C.J., Mueller, D.K., and Crawford, C.G., 2012, Assessing total nitrogen in surface-water samplesPrecision and bias of analytical and computational methods: U.S. Geological Survey Scientific Investigations Report 2012-5281, 38 p., accessed February 24, 2015, at http://pubs.usgs.gov/sir/2012/5281/.

Shreve, E.A., and Downs, A.C., 2005, Quality-assurance plan for the analysis of fluvial sediment by the U.S. Geological Survey Kentucky Water Science Center Sediment Laboratory: U.S. Geological Survey Open-File Report 2005-1230, 28 p. [Also available at http://pubs.usgs.gov/of/2005/1230/.]
Turnipseed, D.P., and Sauer, V.B., 2010, Discharge measurements at gaging stations: U.S. Geological Survey Techniques and Methods, book 3, chap. A8, 87 p. [Also available at http://pubs.usgs.gov/tm/tm3-a8/.]

Upper Blackstone Water Pollution Abatement District, 2012, Blackstone River water quality study - 2012 update: Millbury, Mass., Upper Blackstone Water Pollution Abatement District, 4 p., accessed February 23, 2015, at http://www.ubwpad.org/ UBWPAD_2012WQSummary_2013Sep10_fin.pdf.

Upper Blackstone Water Pollution Abatement District, 2013, Blackstone River water quality study -2013: Millbury, Mass., Upper Blackstone Water Pollution Abatement District, 2 p., accessed February 23, 2015, at http://www. ubwpad.org/UBWPAD_2013_SamplingUpdate.pdf.

U.S. Army Corps of Engineers, 1997, Blackstone River watershed reconnaissance investigation: U.S. Army Corps of Engineers, v. 1, 143 p. [Also available at http://www.nae.usace.army.mil/Portals/74/docs/Topics/ BlackstoneRestStudy/BRWInvestigationVol1.pdf.]

U.S. Army Corps of Engineers, 1994, Blackstone River restoration study: U.S. Army Corps of Engineers, 85 p. plus appendixes. [Also available at http://www.epa.gov/region1/ superfund/sites/peterson/266278.pdf.]

U.S. Environmental Protection Agency, 2007, Northeast National Estuary Program coastal condition, chap. 3 of National Estuary Program coastal condition report: U.S. Environmental Protection Agency, p. 44-192, accessed September 12, 2014, at http://water.epa.gov/type/oceb/ nep/upload/2007_05_09_oceans_nepccr_pdf_large section2.pdf.

U.S. Environmental Protection Agency, 2014, National pollutant discharge elimination system compliance monitoring: U.S. Environmental Protection Agency Web page, accessed December 22, 2014, at http:/www.epa.gov/compliance/ monitoring/programs/cwa/npdes.html.

U.S. Geological Survey, 2006, Collection of water samples (ver. 2.0): U.S. Geological Survey Techniques of WaterResources Investigations, book 9, chap. A4, September, accessed January 14, 2015, at http://pubs.water.usgs.gov/ twri9A4/.

Vanasse Hangen Brustlin, Inc., 2005, Blackstone canal preservation study_-Blackstone, Millville, Uxbridge, Northbridge, Grafton, Sutton, Millbury, and Worcester, Massachusetts: Watertown, Mass., Vanasse Hangen Brustlin, Inc., 65 p. plus appendixes, accessed June 25, 2013, at http://www.nps.gov/blac/parkmgmt/upload/ BCPS-Final-Report-09-09-05-Double-Sided.pdf. 
Wagner, R.J., Boulger, R.W., Jr., Oblinger, C.J., and Smith, B.A., 2006, Guidelines and standard procedures for continuous water-quality monitors - Station operation, record computation, and data reporting: U.S. Geological Survey Techniques and Methods, book 1, chap. D3, 51 p. plus 8 appendixes, accessed February 6, 2007, at http://pubs.water.usgs.gov/tm1d3/.

Water Resources Research Center, 2015, Blackstone River water quality study: Amherst, Mass., University of Massachusetts Amherst Web page, accessed February 23, 2015, at http://wrrc.umass.edu/research/blackstone-riverwater-quality-study.

Wilde, F.D., ed., 2004, Cleaning of equipment for water sampling (ver. 2.0): U.S. Geological Survey Techniques of Water-Resources Investigations, book 9, chap. A3, April 2004, accessed January 14, 2014, at http://pubs.water.usgs.gov/twri9A3/.

Wilde, F.D., Radtke, D.B., Gibs, Jacob, and Iwatsubo, R.T., eds., 2009, Processing of water samples (version 2.2): U.S. Geological Survey Techniques of Water-Resources Investigations, book 9, chap. A5, accessed January 14, 2014, at http://pubs.water.usgs.gov/twri9A5/.

Wright, R.M., Nolan, P.M., Pincumbe, David, Hartman, Elaine, and Viator, O.J., 2001, Blackstone River initiativeWater quality analysis of the Blackstone River under wet and dry weather conditions: Kingston, R.I., University of Rhode Island, [variously paged]. 

Table 3 
Table 3. Loads of total nitrogen, total phosphorus, and suspended sediment at stream monitoring stations and wastewater treatment plants from 2-week composite samples in the Blackstone River Basin, Massachusetts and Rhode Island, from 2007 to 2009.

[Total nitrogen load values in bold were calculated by using the total dissolved nitrogen $(\mathrm{N})$ concentration value for one or both of the two samples. $\mathrm{kg} / \mathrm{d}$, kilograms per day; N, nitrogen; P, phosphorus; USGS, U.S. Geological Survey; --, no data]

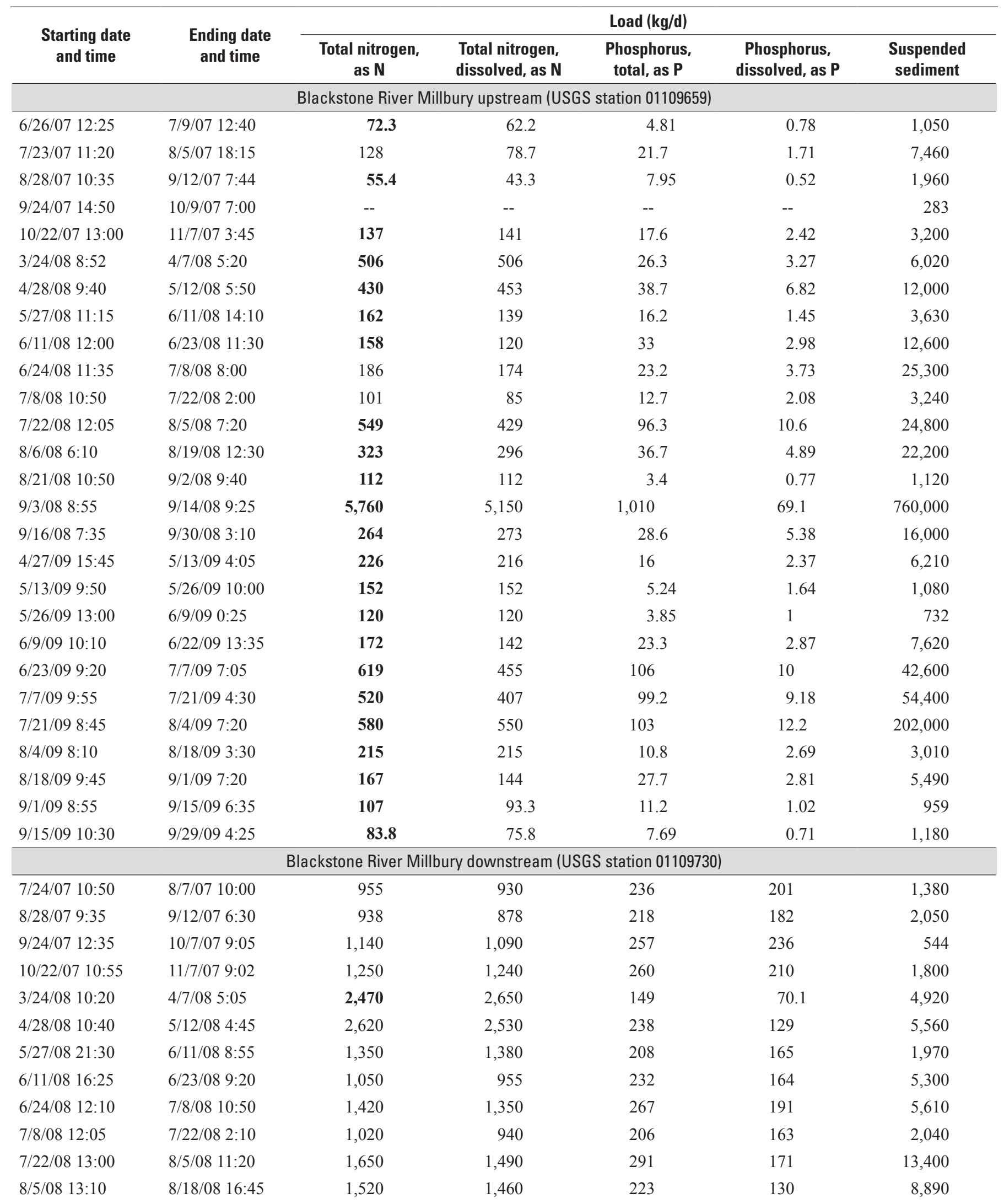


Table 3. Loads of total nitrogen, total phosphorus, and suspended sediment at stream monitoring stations and wastewater treatment plants from 2-week composite samples in the Blackstone River Basin, Massachusetts and Rhode Island, from 2007 to 2009.-Continued

[Total nitrogen load values in bold were calculated by using the total dissolved nitrogen $(\mathrm{N})$ concentration value for one or both of the two samples. $\mathrm{kg} / \mathrm{d}$, kilograms per day; N, nitrogen; P, phosphorus; USGS, U.S. Geological Survey; --, no data]

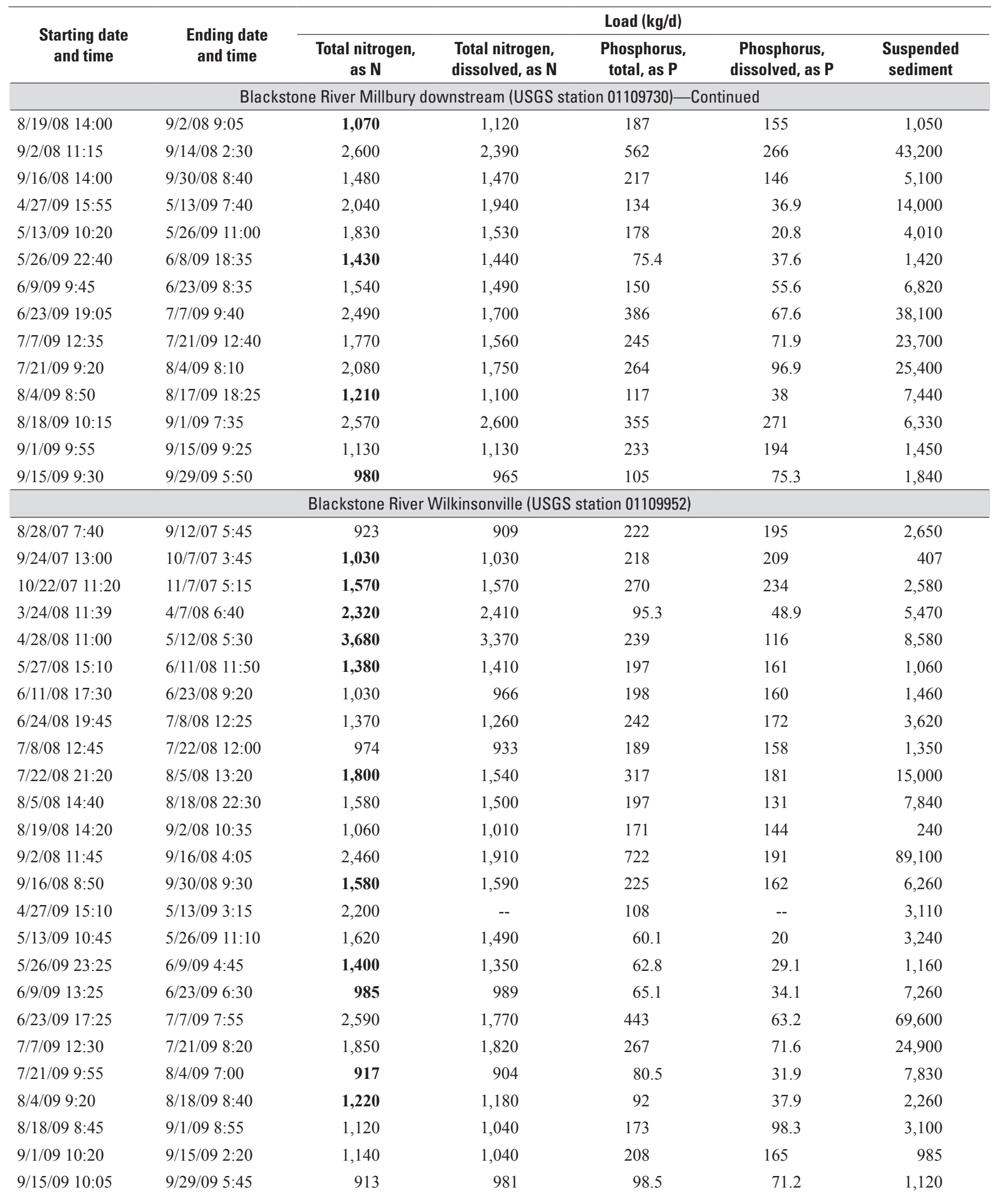


Table 3. Loads of total nitrogen, total phosphorus, and suspended sediment at stream monitoring stations and wastewater treatment plants from 2-week composite samples in the Blackstone River Basin, Massachusetts and Rhode Island, from 2007 to 2009. -Continued

[Total nitrogen load values in bold were calculated by using the total dissolved nitrogen $(\mathrm{N})$ concentration value for one or both of the two samples. $\mathrm{kg} / \mathrm{d}$, kilograms per day; N, nitrogen; P, phosphorus; USGS, U.S. Geological Survey; --, no data]

\begin{tabular}{|c|c|c|c|c|c|c|}
\hline \multirow{2}{*}{$\begin{array}{l}\text { Starting date } \\
\text { and time }\end{array}$} & \multirow{2}{*}{$\begin{array}{c}\text { Ending date } \\
\text { and time }\end{array}$} & \multicolumn{5}{|c|}{ Load (kg/d) } \\
\hline & & $\begin{array}{c}\text { Total nitrogen, } \\
\text { as } \mathbf{N}\end{array}$ & $\begin{array}{l}\text { Total nitrogen, } \\
\text { dissolved, as N }\end{array}$ & $\begin{array}{l}\text { Phosphorus, } \\
\text { total, as P }\end{array}$ & $\begin{array}{c}\text { Phosphorus, } \\
\text { dissolved, as P }\end{array}$ & $\begin{array}{c}\text { Suspended } \\
\text { sediment }\end{array}$ \\
\hline $6 / 27 / 07$ 15:00 & 7/10/07 13:40 & 22.8 & 22.8 & 0.59 & 0.31 & 139 \\
\hline $7 / 23 / 07$ 14:30 & 8/7/07 2:00 & 20.2 & 20.2 & 1.24 & 1.03 & 253 \\
\hline 8/28/07 8:10 & $9 / 12 / 077: 15$ & 6.35 & 6.35 & 0.23 & 0.1 & 36 \\
\hline 9/24/07 13:20 & 10/9/07 5:40 & 5.12 & 5.12 & 0.03 & 0.02 & 6 \\
\hline 10/22/07 11:45 & 11/7/07 13:00 & 9.11 & 9.11 & 0.18 & 0.09 & 20 \\
\hline $3 / 24 / 0817: 15$ & $4 / 7 / 082: 35$ & 317 & 317 & 6.3 & 0.96 & 1,260 \\
\hline $4 / 28 / 08 \quad 11: 25$ & 5/8/08 3:05 & 189 & 193 & 6.08 & 2.38 & 4,380 \\
\hline $5 / 27 / 08 \quad 14: 20$ & 6/7/08 11:30 & 103 & 90.7 & 4.26 & 1.29 & 931 \\
\hline 6/11/08 17:40 & $6 / 24 / 08$ 14:50 & 46.8 & 46.1 & 3.22 & 1.25 & 631 \\
\hline 6/24/08 18:40 & 7/7/08 8:00 & 58.4 & 59.7 & 3.5 & 1.61 & 668 \\
\hline 7/8/08 16:00 & $7 / 22 / 085: 35$ & 29.8 & 29.8 & 1.17 & 0.58 & 229 \\
\hline 7/23/08 0:00 & $8 / 5 / 0815: 15$ & 89 & 83.9 & 7.56 & 3.22 & 986 \\
\hline 8/6/08 11:35 & 8/16/08 19:40 & 159 & 159 & 9.17 & 4.18 & 1,560 \\
\hline $8 / 19 / 08$ 16:05 & 9/2/08 14:35 & 56.2 & 56.2 & 1.09 & 0.53 & 78 \\
\hline 9/2/08 16:20 & 9/14/08 4:30 & 137 & 138 & 9.39 & 3.63 & 757 \\
\hline 9/16/08 9:45 & 9/30/08 13:00 & 62.9 & 62.9 & 3.05 & 1.23 & 219 \\
\hline 4/27/09 15:55 & 5/13/09 9:50 & 121 & 121 & 3.3 & 1.47 & 749 \\
\hline 5/13/09 12:10 & $5 / 26 / 0910: 50$ & 79.2 & 79.2 & 1.88 & 1.2 & 423 \\
\hline 5/26/09 17:20 & 6/9/09 8:15 & 65.7 & 65.7 & 2.09 & 0.67 & 568 \\
\hline 6/9/09 12:00 & $6 / 23 / 097: 50$ & 89.4 & 89.4 & 5.24 & 1.72 & 961 \\
\hline 6/23/09 17:55 & 7/7/09 10:45 & 180 & 183 & 13.4 & 3.82 & 4,680 \\
\hline $7 / 7 / 09$ 12:15 & 7/21/09 7:00 & 283 & 283 & 15.8 & 5.41 & 2,460 \\
\hline $7 / 21 / 0910: 25$ & 8/4/09 5:00 & 312 & 312 & 15.3 & 4.86 & 2,650 \\
\hline 8/4/09 9:55 & $8 / 17 / 09$ 16:50 & 152 & 152 & 4.41 & 1.45 & 957 \\
\hline 8/18/09 9:10 & $9 / 1 / 098: 55$ & 62.5 & 62.5 & 3.3 & 1.06 & 493 \\
\hline 9/1/09 10:50 & 9/15/09 10:10 & 47.3 & 47.3 & 1.4 & 0.55 & 179 \\
\hline 9/15/09 10:30 & 9/28/09 21:15 & 40.6 & 40.6 & 0.74 & 0.43 & 49 \\
\hline \multicolumn{7}{|c|}{ Blackstone River South Grafton (USGS station 01110400) } \\
\hline $8 / 28 / 079: 55$ & $9 / 12 / 076: 25$ & 824 & 831 & 192 & 148 & 2,590 \\
\hline 9/24/07 13:50 & $10 / 6 / 0718: 45$ & 958 & 947 & 195 & 170 & 1,070 \\
\hline 10/22/07 12:10 & 11/7/07 14:10 & 1,480 & 1,580 & 278 & 214 & 3,890 \\
\hline $3 / 24 / 0812: 35$ & 4/7/08 6:50 & 3,560 & 3,590 & 188 & 83.7 & 8,140 \\
\hline 4/29/08 7:55 & $5 / 12 / 085: 10$ & 3,590 & 3,530 & 314 & 178 & 10,200 \\
\hline $5 / 27 / 0814: 00$ & $6 / 10 / 08$ 17:05 & 1,010 & 935 & 221 & 79.4 & 11,300 \\
\hline $6 / 11 / 0816: 35$ & $6 / 22 / 0814: 30$ & 1,260 & 1,160 & 231 & 152 & 3,430 \\
\hline 6/24/08 16:40 & 7/8/08 16:04 & 1,540 & 1,450 & 283 & 185 & 8,660 \\
\hline 7/8/08 16:05 & $7 / 22 / 0814: 20$ & 1,000 & 937 & 222 & 133 & 4,660 \\
\hline 7/23/08 2:00 & 8/3/08 0:00 & 2,300 & 2,030 & 587 & 226 & 42,800 \\
\hline $8 / 5 / 0812: 15$ & 8/19/08 15:00 & 2,130 & 2,070 & 358 & 181 & 15,400 \\
\hline 8/19/08 15:40 & 9/1/08 0:15 & 1,110 & 1,130 & 184 & 123 & 3,090 \\
\hline
\end{tabular}


Table 3. Loads of total nitrogen, total phosphorus, and suspended sediment at stream monitoring stations and wastewater treatment plants from 2-week composite samples in the Blackstone River Basin, Massachusetts and Rhode Island, from 2007 to 2009.-Continued

[Total nitrogen load values in bold were calculated by using the total dissolved nitrogen $(\mathrm{N})$ concentration value for one or both of the two samples. $\mathrm{kg} / \mathrm{d}$, kilograms per day; N, nitrogen; P, phosphorus; USGS, U.S. Geological Survey; --, no data]

\begin{tabular}{|c|c|c|c|c|c|c|}
\hline \multirow{2}{*}{$\begin{array}{l}\text { Starting date } \\
\text { and time }\end{array}$} & \multirow{2}{*}{$\begin{array}{l}\text { Ending date } \\
\text { and time }\end{array}$} & \multicolumn{5}{|c|}{ Load (kg/d) } \\
\hline & & $\begin{array}{c}\text { Total nitrogen, } \\
\text { as } \mathbf{N}\end{array}$ & $\begin{array}{l}\text { Total nitrogen, } \\
\text { dissolved, as N }\end{array}$ & $\begin{array}{c}\text { Phosphorus, } \\
\text { total, as P }\end{array}$ & $\begin{array}{l}\text { Phosphorus, } \\
\text { dissolved, as P }\end{array}$ & $\begin{array}{c}\text { Suspended } \\
\text { sediment }\end{array}$ \\
\hline $9 / 2 / 0816: 00$ & 9/13/08 12:00 & 3,290 & 2,780 & 1,040 & 254 & 98,400 \\
\hline $9 / 16 / 089: 15$ & $9 / 30 / 08 \quad 12: 45$ & 1,880 & 1,750 & 305 & 152 & 20,800 \\
\hline $5 / 27 / 099: 45$ & $6 / 9 / 096: 50$ & 1,430 & 1,430 & 98.9 & 46.2 & 2,910 \\
\hline $6 / 9 / 09$ 12:50 & 6/22/09 19:30 & 1,680 & 1,750 & 210 & 77.7 & 15,300 \\
\hline $6 / 23 / 0921: 50$ & 7/7/09 12:20 & 2,920 & 2,400 & 594 & 108 & 83,900 \\
\hline 7/7/09 13:00 & $7 / 21 / 0910: 50$ & 2,370 & 715 & 399 & 21.6 & 41,800 \\
\hline $9 / 1 / 0911: 15$ & $9 / 15 / 096: 55$ & 860 & 854 & 132 & 83.5 & 6,670 \\
\hline $9 / 15 / 09$ 11:15 & 9/29/09 7:00 & 992 & 980 & 137 & 92.8 & 3,350 \\
\hline \multicolumn{7}{|c|}{ Mumford River (USGS station 01111050) } \\
\hline $7 / 24 / 0714: 15$ & $8 / 6 / 0710: 55$ & 20 & 20 & 0.97 & 0.36 & 170 \\
\hline 8/28/07 14:15 & 9/10/07 10:30 & 10.9 & 10.9 & 0.42 & 0.78 & 52.8 \\
\hline 9/24/07 15:40 & $10 / 9 / 0710: 25$ & 7.11 & 7.11 & 0.3 & 0.11 & 56.1 \\
\hline $10 / 22 / 0715: 25$ & 11/7/07 1:40 & -- & 39.4 & 1.36 & 0.41 & 671 \\
\hline $3 / 24 / 0816: 20$ & 4/7/08 7:00 & 638 & 638 & 5.98 & 1.5 & 1,450 \\
\hline 4/28/08 12:20 & $5 / 12 / 0810: 35$ & 200 & 200 & 7.08 & 3.78 & 1,190 \\
\hline $8 / 5 / 0812: 10$ & $8 / 19 / 084: 55$ & 63.5 & 61.8 & 3.8 & 1.34 & 740 \\
\hline $8 / 19 / 08$ 15:15 & 9/2/08 5:35 & -- & 33.3 & -- & 0.38 & 107 \\
\hline 9/2/08 14:45 & 9/16/08 5:50 & 99 & 99 & 4.2 & 2.27 & 815 \\
\hline 9/16/08 11:15 & 9/30/08 14:05 & 101 & 101 & 3.35 & 1.65 & 395 \\
\hline 4/28/09 16:40 & $5 / 14 / 0910: 25$ & 90.7 & -- & 4.89 & -- & 979 \\
\hline $5 / 14 / 09$ 23:05 & $5 / 27 / 095: 50$ & 154 & 154 & 2.4 & 1.06 & 332 \\
\hline $5 / 27 / 0911: 10$ & 6/9/09 17:40 & 78.8 & 78.8 & 2.09 & 0.68 & 325 \\
\hline 6/10/09 12:20 & 6/24/09 11:00 & 76.8 & 76.8 & 3.18 & 1.12 & 496 \\
\hline 6/24/09 11:05 & 7/8/09 8:25 & 203 & 203 & 11 & 3.95 & 2,270 \\
\hline 7/8/09 11:15 & $7 / 22 / 096: 05$ & 256 & 256 & 6.61 & 2.2 & 2,010 \\
\hline $7 / 22 / 09$ 10:20 & $8 / 4 / 0923: 10$ & 327 & 327 & 23.6 & 8.34 & 3,130 \\
\hline $8 / 5 / 09$ 10:50 & 8/19/09 1:40 & 152 & 152 & 10.7 & 1.94 & 1,470 \\
\hline 8/19/09 8:45 & 9/2/09 5:25 & 68.5 & 68.5 & 4.96 & 1.18 & 590 \\
\hline 9/2/09 9:30 & 9/16/09 7:05 & 89.6 & 89.6 & 2.67 & 1.1 & 409 \\
\hline 9/16/09 9:10 & 9/30/09 17:10 & 70.8 & 70.8 & 1.41 & 0.69 & 313 \\
\hline
\end{tabular}


Table 3. Loads of total nitrogen, total phosphorus, and suspended sediment at stream monitoring stations and wastewater treatment plants from 2-week composite samples in the Blackstone River Basin, Massachusetts and Rhode Island, from 2007 to 2009. -Continued

[Total nitrogen load values in bold were calculated by using the total dissolved nitrogen $(\mathrm{N})$ concentration value for one or both of the two samples. $\mathrm{kg} / \mathrm{d}$, kilograms per day; N, nitrogen; P, phosphorus; USGS, U.S. Geological Survey; --, no data]

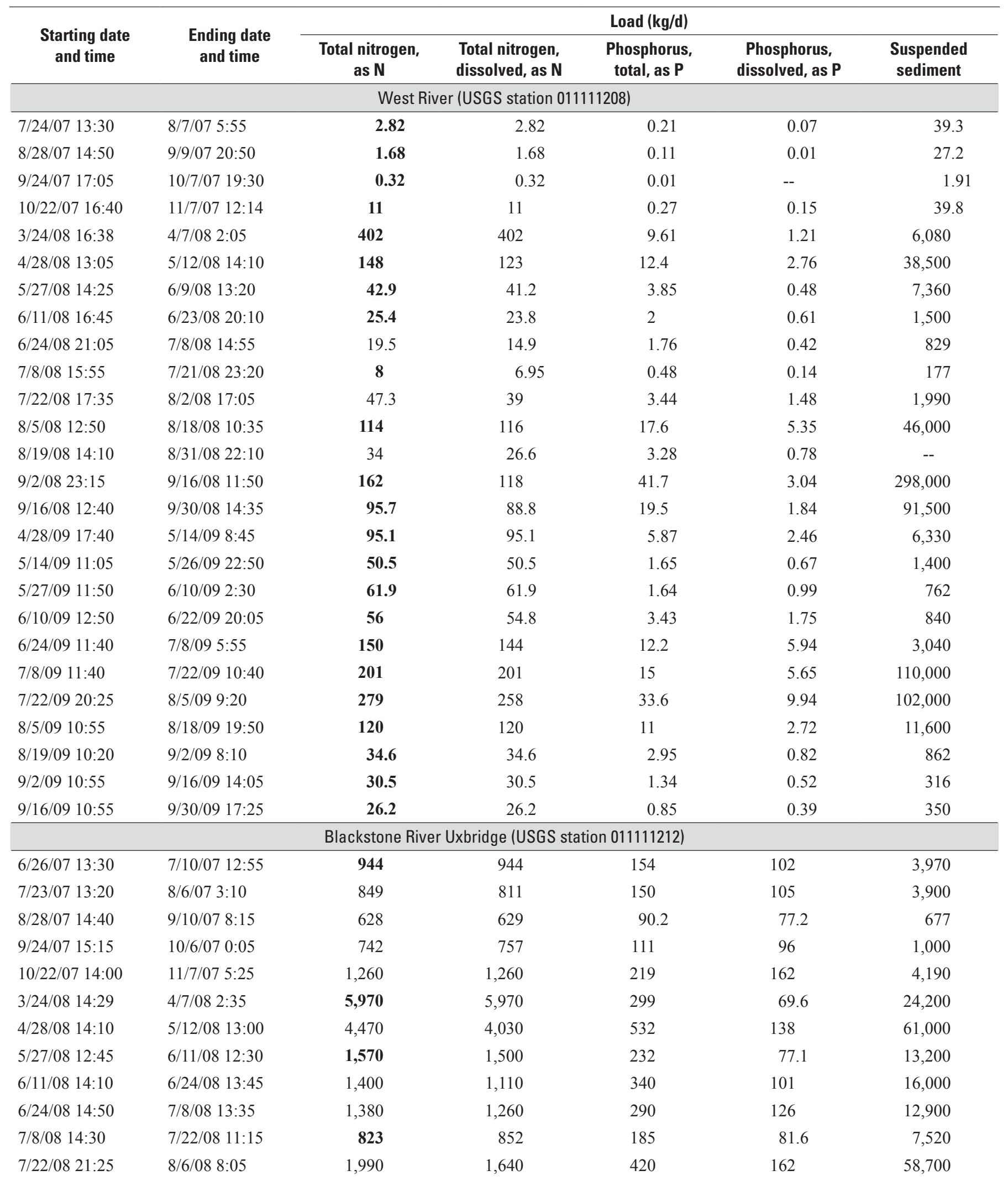


Table 3. Loads of total nitrogen, total phosphorus, and suspended sediment at stream monitoring stations and wastewater treatment plants from 2-week composite samples in the Blackstone River Basin, Massachusetts and Rhode Island, from 2007 to 2009. - Continued

[Total nitrogen load values in bold were calculated by using the total dissolved nitrogen $(\mathrm{N})$ concentration value for one or both of the two samples. $\mathrm{kg} / \mathrm{d}$, kilograms per day; N, nitrogen; P, phosphorus; USGS, U.S. Geological Survey; --, no data]

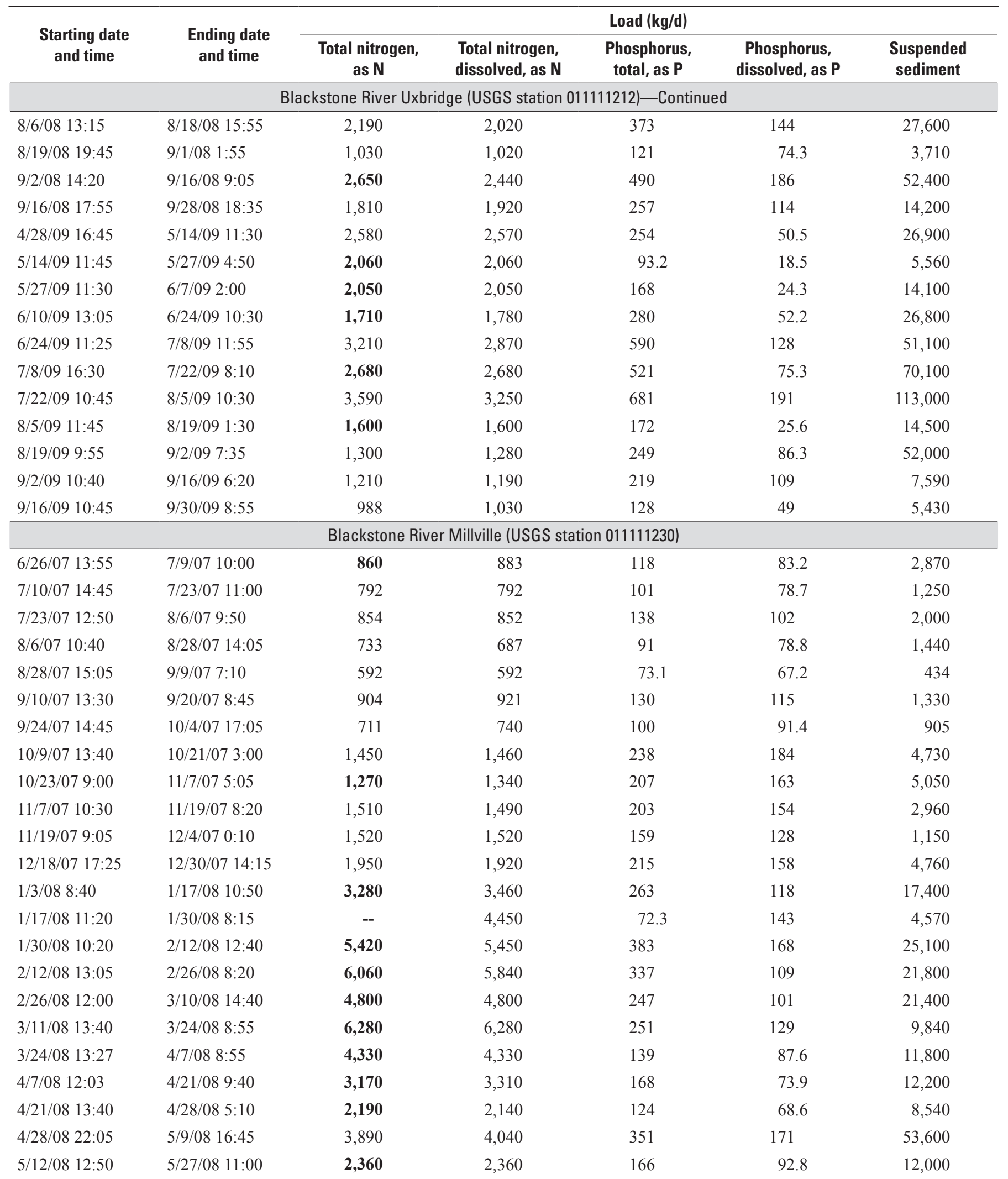


Table 3. Loads of total nitrogen, total phosphorus, and suspended sediment at stream monitoring stations and wastewater treatment plants from 2-week composite samples in the Blackstone River Basin, Massachusetts and Rhode Island, from 2007 to 2009. -Continued

[Total nitrogen load values in bold were calculated by using the total dissolved nitrogen $(\mathrm{N})$ concentration value for one or both of the two samples. $\mathrm{kg} / \mathrm{d}$, kilograms per day; N, nitrogen; P, phosphorus; USGS, U.S. Geological Survey; --, no data]

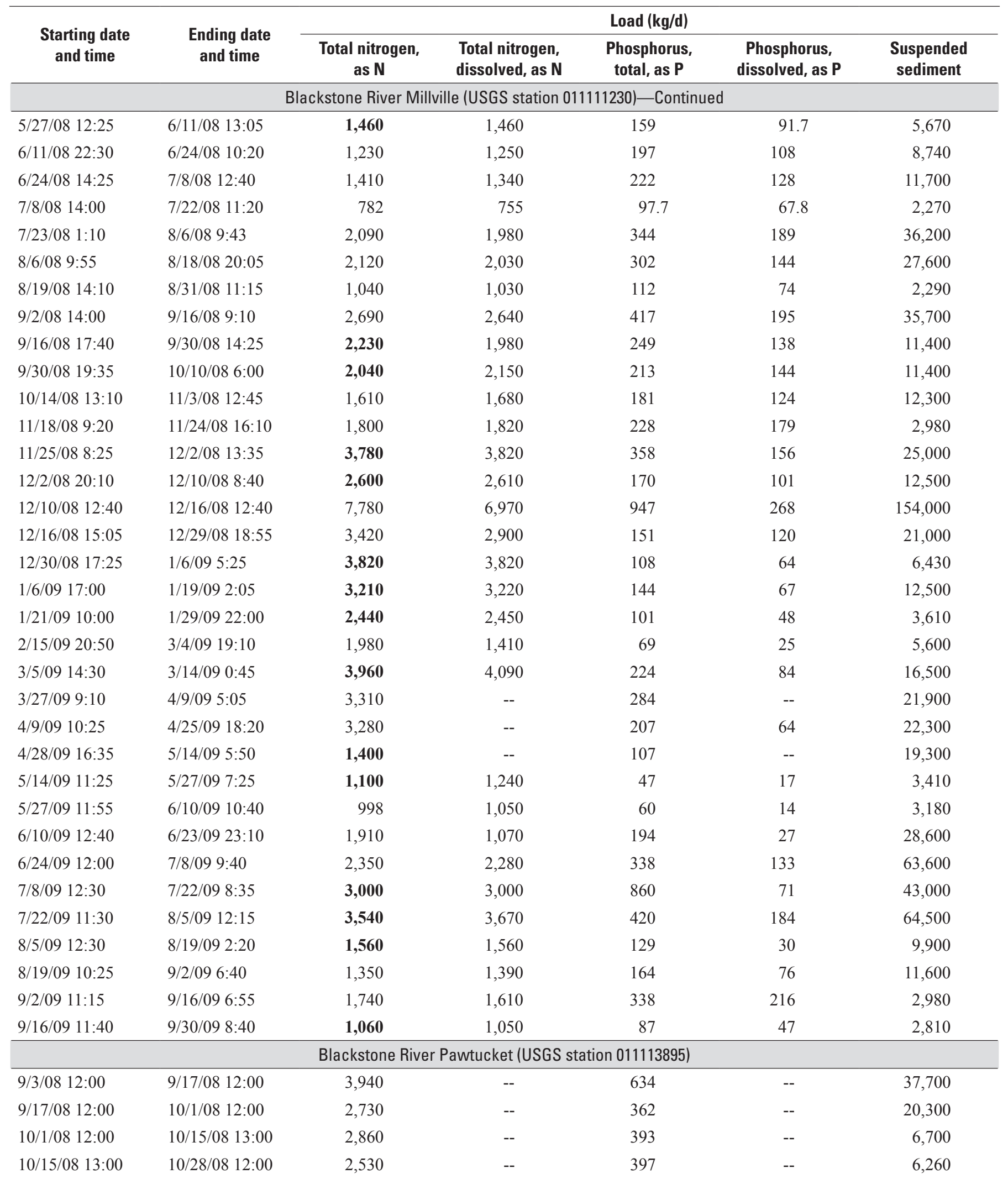


Table 3. Loads of total nitrogen, total phosphorus, and suspended sediment at stream monitoring stations and wastewater treatment plants from 2-week composite samples in the Blackstone River Basin, Massachusetts and Rhode Island, from 2007 to 2009.-Continued

[Total nitrogen load values in bold were calculated by using the total dissolved nitrogen $(\mathrm{N})$ concentration value for one or both of the two samples. $\mathrm{kg} / \mathrm{d}$, kilograms per day; N, nitrogen; P, phosphorus; USGS, U.S. Geological Survey; --, no data]

\begin{tabular}{|c|c|c|c|c|c|c|}
\hline \multirow{2}{*}{$\begin{array}{l}\text { Starting date } \\
\text { and time }\end{array}$} & \multirow{2}{*}{$\begin{array}{l}\text { Ending date } \\
\text { and time }\end{array}$} & \multicolumn{5}{|c|}{ Load (kg/d) } \\
\hline & & $\begin{array}{c}\text { Total nitrogen, } \\
\text { as } \mathbf{N}\end{array}$ & $\begin{array}{l}\text { Total nitrogen, } \\
\text { dissolved, as N }\end{array}$ & $\begin{array}{l}\text { Phosphorus, } \\
\text { total, as P }\end{array}$ & $\begin{array}{c}\text { Phosphorus, } \\
\text { dissolved, as P }\end{array}$ & $\begin{array}{c}\text { Suspended } \\
\text { sediment }\end{array}$ \\
\hline \multicolumn{7}{|c|}{ Blackstone River Pawtucket (USGS station 011113895)_-Continued } \\
\hline $5 / 14 / 0912: 00$ & 5/27/09 12:00 & 2,160 & -- & 109 & -- & 8,480 \\
\hline 5/28/09 12:00 & 6/11/09 12:00 & 1,490 & -- & 66.0 & -- & -- \\
\hline 7/8/09 12:00 & 7/22/09 12:00 & 3,390 & -- & 399 & -- & 8,130 \\
\hline $7 / 22 / 09$ 12:00 & 8/6/09 12:00 & 5,170 & -- & 949 & -- & 124,000 \\
\hline 8/6/09 8:00 & 8/20/09 8:45 & 1,990 & -- & 148 & -- & 16,800 \\
\hline $8 / 20 / 098: 45$ & 8/31/09 0:00 & 1,890 & -- & 128 & -- & -- \\
\hline $5 / 24 / 07$ & $6 / 6 / 07$ & 159 & 153 & 15.1 & 14.6 & -- \\
\hline $6 / 25 / 07$ & $7 / 8 / 07$ & 125 & 125 & 12 & 11.7 & -- \\
\hline $7 / 24 / 07$ & $8 / 6 / 07$ & 118 & 121 & 11.6 & 11 & -- \\
\hline $8 / 29 / 07$ & $9 / 11 / 07$ & 124 & 123 & 13.2 & 13.8 & -- \\
\hline $9 / 25 / 07$ & $10 / 8 / 07$ & 116 & 116 & 12.4 & 11.8 & -- \\
\hline $10 / 23 / 07$ & $11 / 5 / 07$ & 156 & 141 & 6.77 & 6.33 & -- \\
\hline $3 / 24 / 08$ & $4 / 6 / 08$ & 197 & 202 & 15.8 & 14.9 & -- \\
\hline $4 / 29 / 08$ & $5 / 12 / 08$ & 200 & 197 & 18.8 & 16.8 & -- \\
\hline $5 / 28 / 08$ & $6 / 10 / 08$ & 107 & 107 & 13.2 & 13.9 & -- \\
\hline $6 / 11 / 09$ & $6 / 24 / 09$ & 135 & 135 & 20.6 & 20.3 & -- \\
\hline 7/9/09 & 7/22/09 & 110 & 102 & 13.9 & 12.4 & -- \\
\hline $8 / 6 / 09$ & 8/19/09 & 75.8 & 72.9 & 10.5 & 10 & -- \\
\hline $9 / 3 / 09$ & $9 / 16 / 09$ & 85.9 & 95.9 & 13.9 & 14.3 & -- \\
\hline \multicolumn{7}{|c|}{ Northbridge wastewater treatment plant (USGS station 420647071380801) } \\
\hline $5 / 24 / 07$ & $6 / 6 / 07$ & 27.6 & 27.7 & 3.59 & 3.45 & -- \\
\hline $6 / 25 / 07$ & $7 / 8 / 07$ & 35.5 & 37.5 & 1.46 & 1.16 & -- \\
\hline $7 / 24 / 07$ & $8 / 6 / 07$ & 62.9 & 66.7 & 0.56 & 0.3 & -- \\
\hline $8 / 29 / 07$ & $9 / 11 / 07$ & 36.4 & 37.4 & 0.38 & 0.21 & -- \\
\hline $9 / 25 / 07$ & $10 / 8 / 07$ & 72.6 & 72.9 & 2.36 & 2.18 & -- \\
\hline $10 / 23 / 07$ & $11 / 5 / 07$ & 51.6 & 51.2 & 4.76 & 4.23 & -- \\
\hline $3 / 25 / 08$ & 4/8/08 & 43.6 & 41.9 & 4.16 & 3.42 & -- \\
\hline $4 / 29 / 08$ & $5 / 12 / 08$ & 43.5 & 42.9 & 0.79 & 0.39 & -- \\
\hline $5 / 28 / 08$ & $6 / 10 / 08$ & 46.9 & 46.9 & 0.7 & 0.39 & -- \\
\hline
\end{tabular}


Table 3. Loads of total nitrogen, total phosphorus, and suspended sediment at stream monitoring stations and wastewater treatment plants from 2-week composite samples in the Blackstone River Basin, Massachusetts and Rhode Island, from 2007 to 2009. -Continued

[Total nitrogen load values in bold were calculated by using the total dissolved nitrogen $(\mathrm{N})$ concentration value for one or both of the two samples. $\mathrm{kg} / \mathrm{d}$, kilograms per day; N, nitrogen; P, phosphorus; USGS, U.S. Geological Survey; --, no data]

\begin{tabular}{|c|c|c|c|c|c|c|}
\hline \multirow{2}{*}{$\begin{array}{l}\text { Starting date } \\
\text { and time }\end{array}$} & \multirow{2}{*}{$\begin{array}{c}\text { Ending date } \\
\text { and time }\end{array}$} & \multicolumn{5}{|c|}{ Load (kg/d) } \\
\hline & & $\begin{array}{c}\text { Total nitrogen, } \\
\text { as } \mathbf{N}\end{array}$ & $\begin{array}{l}\text { Total nitrogen, } \\
\text { dissolved, as N }\end{array}$ & $\begin{array}{l}\text { Phosphorus, } \\
\text { total, as P }\end{array}$ & $\begin{array}{c}\text { Phosphorus, } \\
\text { dissolved, as P }\end{array}$ & $\begin{array}{c}\text { Suspended } \\
\text { sediment }\end{array}$ \\
\hline \multicolumn{7}{|c|}{ Northbridge wastewater treatment plant (USGS station 420647071380801)_Continued } \\
\hline $6 / 25 / 08$ & $7 / 8 / 08$ & 32 & 32.2 & 1.42 & 1.13 & -- \\
\hline $7 / 23 / 08$ & $8 / 5 / 08$ & 45.1 & 44.7 & 0.83 & 0.53 & -- \\
\hline $8 / 20 / 08$ & $9 / 2 / 08$ & 43.2 & 45.5 & 0.4 & 0.1 & -- \\
\hline $9 / 17 / 08$ & 9/30/08 & 47.2 & 44.4 & 0.49 & 0.21 & -- \\
\hline $5 / 14 / 09$ & $5 / 27 / 09$ & 42.2 & 41 & 0.78 & 0.41 & -- \\
\hline $6 / 11 / 09$ & $6 / 24 / 09$ & 38.5 & 39.9 & 0.51 & 0.34 & -- \\
\hline 7/9/09 & $7 / 22 / 09$ & 44.3 & 45 & 0.3 & 0.23 & -- \\
\hline $8 / 6 / 09$ & 8/19/09 & 49.8 & 50.2 & 0.61 & 0.51 & -- \\
\hline $9 / 3 / 09$ & $9 / 16 / 09$ & 50.7 & 51.9 & 0.6 & 0.42 & -- \\
\hline \multicolumn{7}{|c|}{ Upper Blackstone Water Pollution Abatement District wastewater treatment plant (USGS station 421241071472701) } \\
\hline $5 / 22 / 07$ & $6 / 4 / 07$ & 1,240 & 1,230 & 139 & 120 & -- \\
\hline $6 / 24 / 07$ & 7/7/07 & 620 & 605 & 177 & 174 & -- \\
\hline $7 / 22 / 07$ & $8 / 4 / 07$ & 657 & 683 & 197 & 191 & -- \\
\hline $8 / 28 / 07$ & $9 / 10 / 07$ & 870 & 890 & 205 & 207 & -- \\
\hline $9 / 25 / 07$ & $10 / 7 / 07$ & 1,250 & 1,200 & 308 & 289 & -- \\
\hline $10 / 22 / 07$ & $11 / 4 / 07$ & 1,000 & 1,270 & 215 & 266 & -- \\
\hline $3 / 23 / 08$ & $4 / 5 / 08$ & 2,030 & 2,320 & 112 & 82.7 & -- \\
\hline $4 / 28 / 08$ & $5 / 11 / 08$ & 2,070 & 2,020 & 167 & 136 & -- \\
\hline $5 / 26 / 08$ & $6 / 8 / 08$ & 1,170 & 1,190 & 170 & 174 & -- \\
\hline $6 / 24 / 08$ & 7/7/08 & 1,050 & 1,090 & 208 & 191 & -- \\
\hline $7 / 21 / 08$ & $8 / 3 / 08$ & 1,110 & 965 & 187 & 166 & -- \\
\hline $8 / 19 / 08$ & $9 / 1 / 08$ & 948 & 948 & 176 & 169 & -- \\
\hline $9 / 16 / 08$ & 9/29/08 & 1,140 & 1,210 & 174 & 162 & -- \\
\hline $5 / 13 / 09$ & $5 / 26 / 09$ & 1,330 & 1,260 & 38.7 & 27.3 & -- \\
\hline $6 / 10 / 09$ & $6 / 23 / 09$ & 1,140 & 1,160 & 103 & 64.4 & -- \\
\hline 7/8/09 & 7/21/09 & 1,060 & 1,030 & 116 & 93.2 & -- \\
\hline $8 / 5 / 09$ & 8/18/09 & 908 & 890 & 94 & 82.8 & -- \\
\hline $9 / 2 / 09$ & 9/15/09 & 1,050 & 1,030 & 217 & 205 & -- \\
\hline \multicolumn{7}{|c|}{ Uxbridge wastewater treatment plant (USGS station 420215071365301) } \\
\hline $5 / 23 / 07$ & $6 / 5 / 07$ & 39.3 & 39.8 & 0.32 & 0.17 & -- \\
\hline $6 / 26 / 07$ & $7 / 9 / 07$ & 36 & 37.8 & 0.22 & 0.16 & -- \\
\hline $7 / 24 / 07$ & $8 / 6 / 07$ & 27.2 & 27.9 & 2.19 & 2.09 & -- \\
\hline $8 / 29 / 07$ & $9 / 11 / 07$ & 27.5 & 28.3 & 0.81 & 0.76 & -- \\
\hline $9 / 25 / 07$ & $10 / 8 / 07$ & 29.6 & 29.3 & 0.28 & 0.33 & -- \\
\hline $10 / 23 / 07$ & $11 / 5 / 07$ & 33.4 & 33.6 & 0.34 & 0.18 & -- \\
\hline $3 / 25 / 08$ & $4 / 7 / 08$ & 37.9 & 38.3 & 8.08 & 7.77 & -- \\
\hline $4 / 29 / 08$ & $5 / 12 / 08$ & 34.4 & 34.3 & 2.5 & 2.13 & -- \\
\hline $5 / 28 / 08$ & $6 / 10 / 08$ & 28.1 & 27.5 & 0.76 & 0.76 & -- \\
\hline $6 / 25 / 08$ & $7 / 8 / 08$ & 25.3 & 27.4 & 0.55 & 0.4 & -- \\
\hline
\end{tabular}


Table 3

Table 3. Loads of total nitrogen, total phosphorus, and suspended sediment at stream monitoring stations and wastewater treatment plants from 2-week composite samples in the Blackstone River Basin, Massachusetts and Rhode Island, from 2007 to 2009. - Continued

[Total nitrogen load values in bold were calculated by using the total dissolved nitrogen $(\mathrm{N})$ concentration value for one or both of the two samples. $\mathrm{kg} / \mathrm{d}$, kilograms per day; N, nitrogen; P, phosphorus; USGS, U.S. Geological Survey; --, no data]

\begin{tabular}{|c|c|c|c|c|c|c|}
\hline \multirow{2}{*}{$\begin{array}{l}\text { Starting date } \\
\text { and time }\end{array}$} & \multirow{2}{*}{$\begin{array}{l}\text { Ending date } \\
\text { and time }\end{array}$} & \multicolumn{5}{|c|}{ Load (kg/d) } \\
\hline & & $\begin{array}{c}\text { Total nitrogen, } \\
\text { as N }\end{array}$ & $\begin{array}{l}\text { Total nitrogen, } \\
\text { dissolved, as N }\end{array}$ & $\begin{array}{c}\text { Phosphorus, } \\
\text { total, as P }\end{array}$ & $\begin{array}{c}\text { Phosphorus, } \\
\text { dissolved, as P }\end{array}$ & $\begin{array}{c}\text { Suspended } \\
\text { sediment }\end{array}$ \\
\hline \multicolumn{7}{|c|}{ Uxbridge wastewater treatment plant (USGS station 420215071365301)—Continued } \\
\hline $7 / 23 / 08$ & $8 / 5 / 08$ & 31.6 & 29.6 & 0.84 & 0.58 & -- \\
\hline $8 / 20 / 08$ & $9 / 2 / 08$ & 28.5 & 28.6 & 1.03 & 0.66 & -- \\
\hline $9 / 17 / 08$ & $9 / 30 / 08$ & 29.8 & 30.3 & 1.47 & 1.2 & -- \\
\hline $5 / 14 / 09$ & $5 / 27 / 09$ & 34.1 & 31.2 & 1.26 & 1.02 & -- \\
\hline $6 / 11 / 09$ & $6 / 24 / 09$ & 31.6 & 31.9 & 1.94 & 1.72 & -- \\
\hline 7/9/09 & $7 / 22 / 09$ & 34.1 & 35.8 & 1.84 & 1.44 & -- \\
\hline $8 / 6 / 09$ & $8 / 19 / 09$ & 24.1 & 24.1 & 1.55 & 1.25 & -- \\
\hline 9/3/09 & $9 / 16 / 09$ & 29.8 & 31 & 2.36 & 1.8 & -- \\
\hline
\end{tabular}





\section{Appendixes 1 Through 6}

[Appendixes 1 through 5 are available separately at http://pubs.usgs.gov/sir/2015/5026/; appendix 6 follows]

Appendix 1. Concentrations of Nitrogen and Phosphorus Analytes and Suspended Sediment in Composite Water-Quality Samples Collected at Monitoring Stations in the Blackstone River, Massachusetts and Rhode Island, 2007 to 2009

Appendix 2. Concentrations of Nitrogen and Phosphorus Analytes and Suspended Sediment in Equal-Width Increment and Point Water-Quality Samples Collected at Stream Monitoring Stations in the Blackstone River, Massachusetts, 2007 to 2009

Appendix 3. Concentrations of Trace Elements in Composite Water-Quality Samples Collected at Stream Monitoring Stations in the Blackstone River Basin, Massachusetts and Rhode Island, 2007 to 2009

Appendix 4. Concentrations of Trace Elements in Equal-Width-Increment and Point WaterQuality Samples Collected at Stream Monitoring Stations in the Blackstone River Basin, Massachusetts, 2007 to 2009

Appendix 5. Concentrations of Nitrogen and Phosphorus Analytes and Suspended Sediment in Composite Water-Quality Samples Collected at Wastewater Treatment Plants in the Blackstone River Basin, Massachusetts, 2007 to 2009

Appendix 6. Constituent Loads and Streamflow in the Blackstone River Basin, Massachusetts and Rhode Island, 2007 to 2009 

Appendix 6. Constituent Loads and Streamflow in the Blackstone River Basin, Massachusetts and Rhode Island, 2007 to 2009 
A. Sampling period starting June 26, 2007

Estimated Constituent Load

Total nitrogen

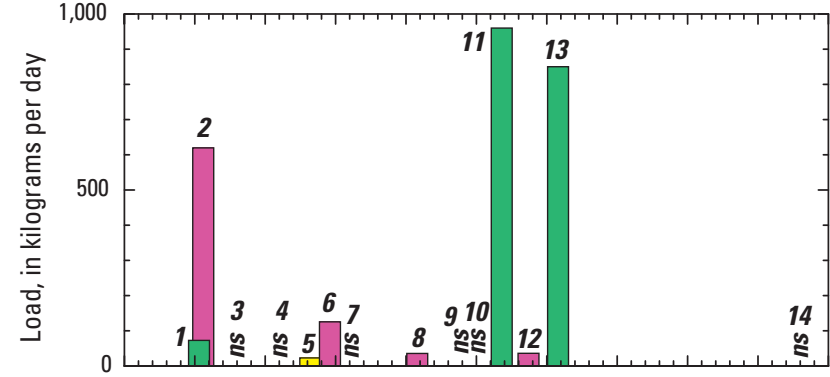

Total phosphorus
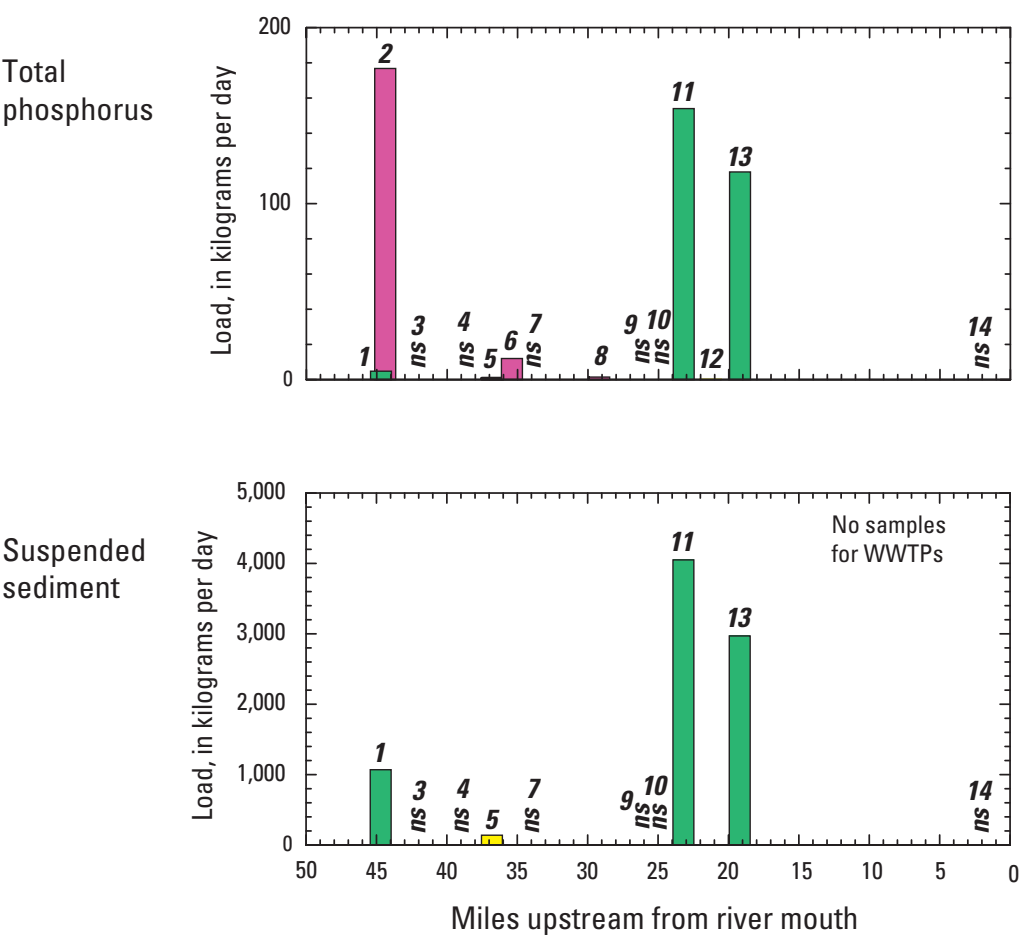

\section{EXPLANATION}

Monitoring station type

$\square$ Mainstem

Wastewater treatment plant (WWTP)

Tributary

\section{Monitoring station name}

1 Blackstone River Millbury upstream (44.7 mi) 2 UBWPAD WWTP (44.4 mi)

3 Blackstone River Millbury downstream (42.0 mi)

4 Blackstone River Wilkinsonville (38.6 mi)

5 Quinsigamond River (36.8 mi)

6 Grafton WWTP (35.4 mi)

7 Blackstone River South Grafton (34.0 mi)

8 Northbridge WWTP (29.2 mi)

9 Mumford River (25.9 mi)

10 West River (24.2 mi)

11 Blackstone River Uxbridge (23.2 mi)

12 Uxbridge WWTP (21.3 mi)

13 Blackstone River Millville (19.2 mi)

14 Blackstone River Pawcatuck (2 mi)

ns no samples
Streamflow at Blackstone River Millville station

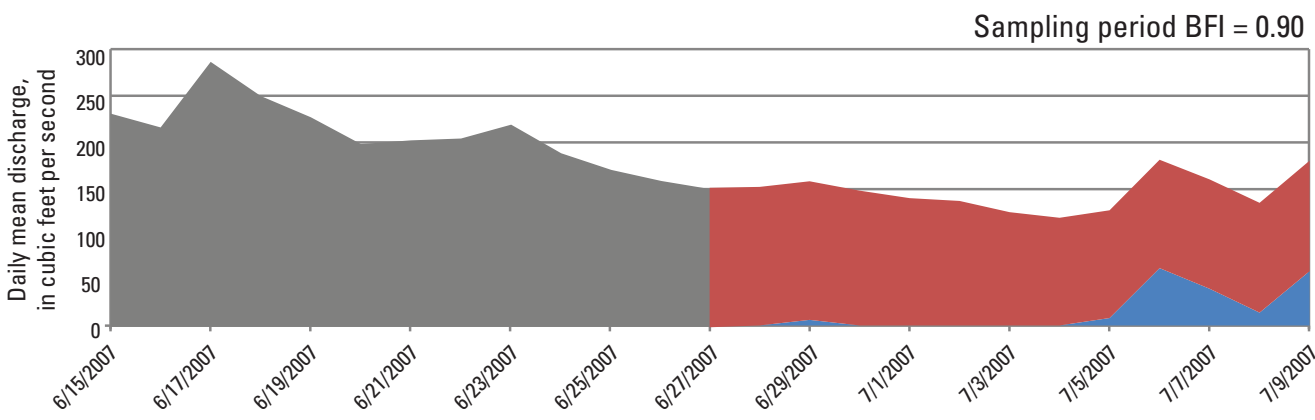

EXPLANATION

Flow component

Antecedent total flow

Sampling period runoff

- Sampling period base flow

Figure 6-1. Constituent loads and streamflow at stream monitoring stations and wastewater treatment plants in the Blackstone River Basin, Massachusetts and Rhode Island, for the sampling period starting $A$, June 26, 2007. BFI, base-flow index (average during the sampling period); mi, miles; UBWPAD, Upper Blackstone Water Pollution Act. 
B. Sampling period starting July 23, 2007

Estimated Constituent Load

Total nitrogen

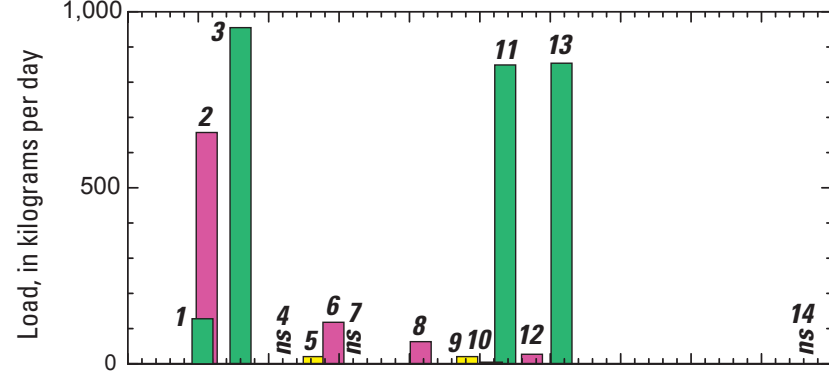

Total phosphorus

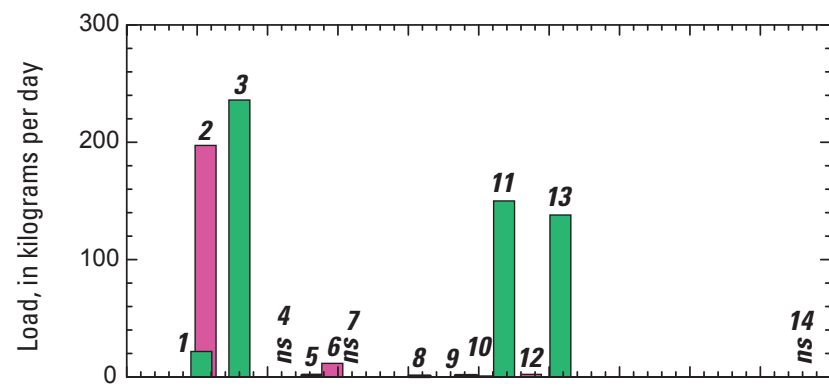

Suspended sediment

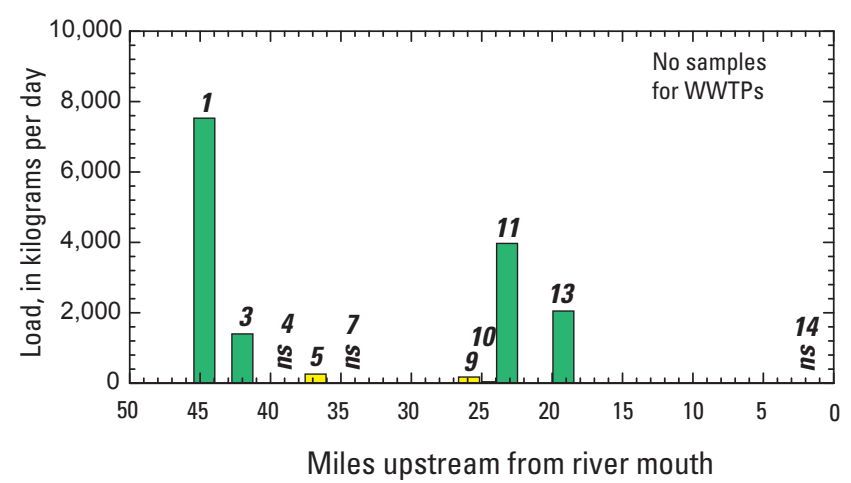

\section{EXPLANATION}

Monitoring station type

$\square$ Mainstem

Wastewater treatment plant (WWTP)

Tributary

Monitoring station name

1 Blackstone River Millbury upstream (44.7 mi) 2 UBWPAD WWTP (44.4 mi)

3 Blackstone River Millbury downstream (42.0 mi)

4 Blackstone River Wilkinsonville (38.6 mi)

5 Quinsigamond River (36.8 mi)

6 Grafton WWTP (35.4 mi)

7 Blackstone River South Grafton (34.0 mi)

8 Northbridge WWTP (29.2 mi)

9 Mumford River (25.9 mi)

10 West River (24.2 mi)

11 Blackstone River Uxbridge (23.2 mi)

12 Uxbridge WWTP (21.3 mi)

13 Blackstone River Millville (19.2 mi)

14 Blackstone River Pawcatuck (2 mi)

ns no samples
Streamflow at Blackstone River Millville station

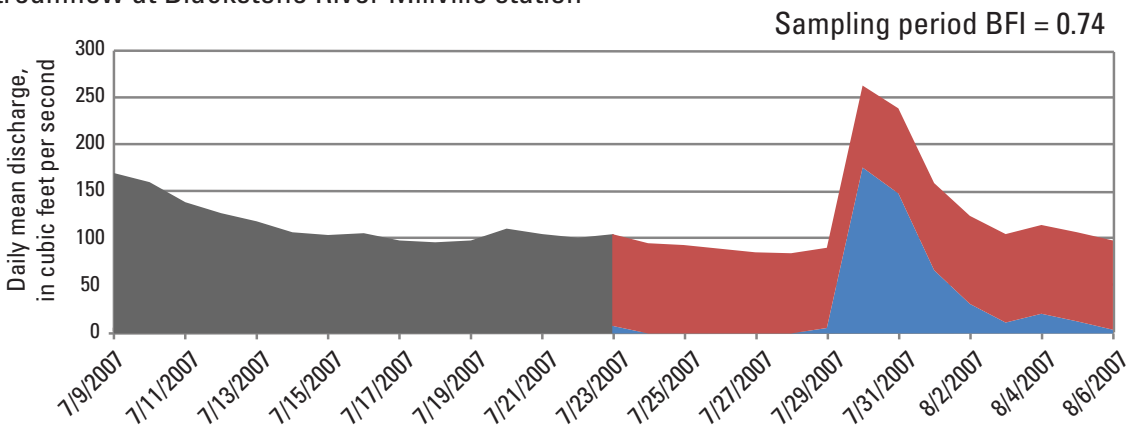

EXPLANATION

Flow component

Antecedent total flow

Sampling period runoff

Sampling period base flow

Figure 6-2. Constituent loads and streamflow at stream monitoring stations and wastewater treatment plants in the Blackstone River Basin, Massachusetts and Rhode Island, for the sampling period starting $B$, July 23, 2007. BFI, base-flow index (average during the sampling period); mi, miles; UBWPAD, Upper Blackstone Water Pollution Abatement District. 
Estimated Constituent Load

Total nitrogen

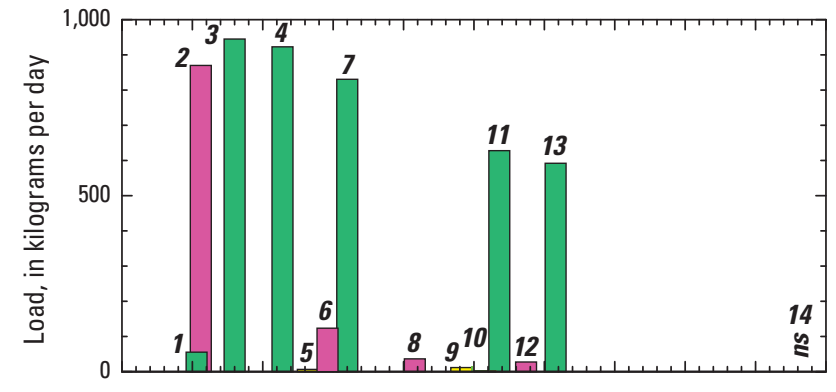

Total phosphorus

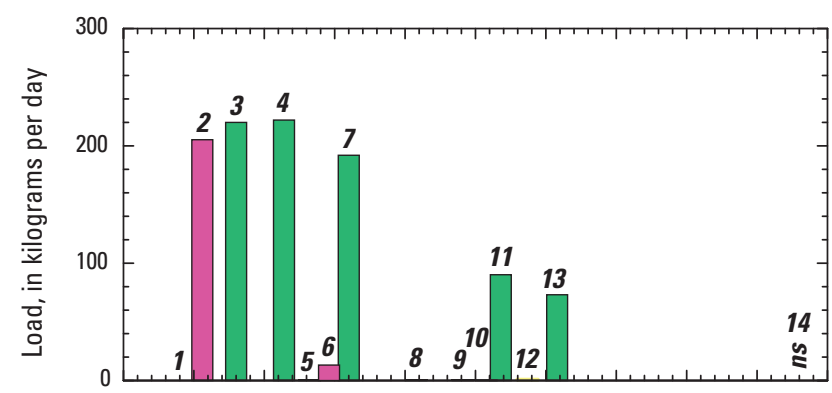

Suspended sediment

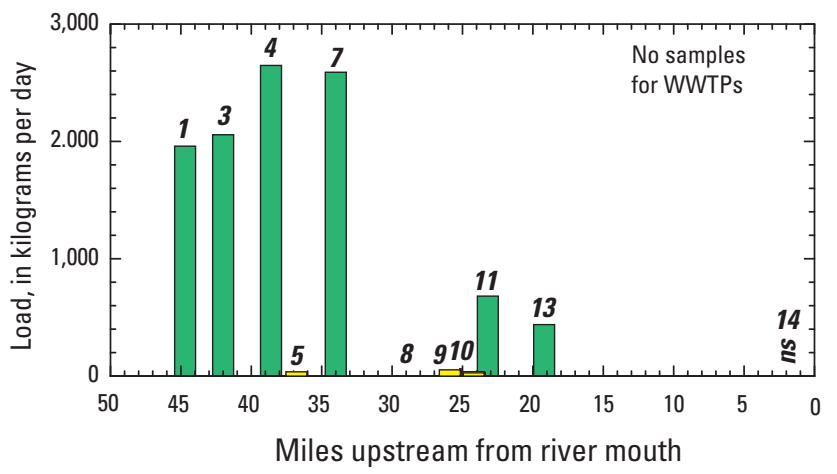

EXPLANATION

Monitoring station type

Mainstem

Wastewater treatment plant (WWTP)

Tributary

\section{Monitoring station name}

1 Blackstone River Millbury upstream (44.7 mi) 2 UBWPAD WWTP (44.4 mi)

3 Blackstone River Millbury downstream (42.0 mi)

4 Blackstone River Wilkinsonville (38.6 mi)

5 Quinsigamond River (36.8 mi)

6 Grafton WWTP (35.4 mi)

7 Blackstone River South Grafton (34.0 mi)

8 Northbridge WWTP (29.2 mi)

9 Mumford River (25.9 mi)

10 West River (24.2 mi)

11 Blackstone River Uxbridge (23.2 mi)

12 Uxbridge WWTP (21.3 mi)

13 Blackstone River Millville (19.2 mi)

14 Blackstone River Pawcatuck (2 mi)

ns no samples
Streamflow at Blackstone River Millville station

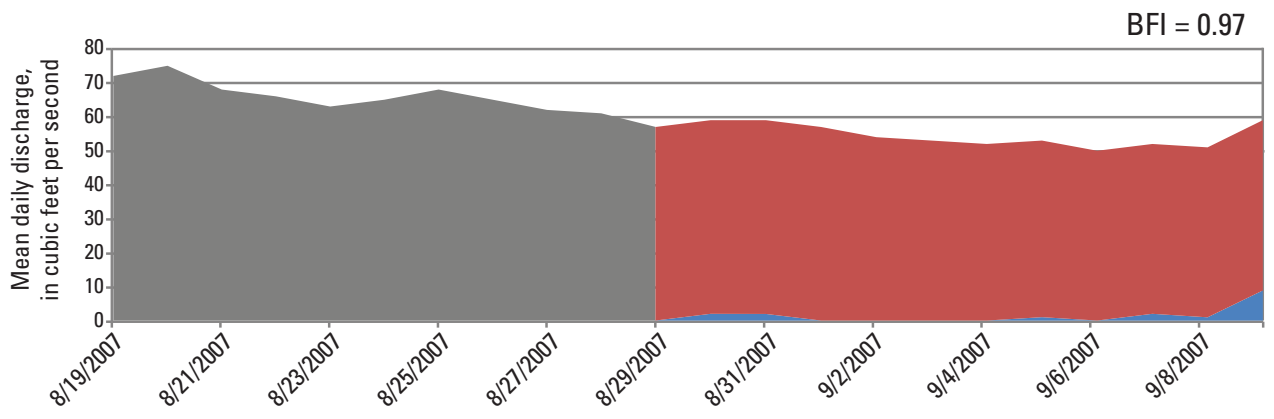

\section{EXPLANATION}

Flow component

Antecedent total flow

Sampling period runoff

Sampling period base flow

Figure 6-3. Constituent loads and streamflow at stream monitoring stations and wastewater treatment plants in the Blackstone River Basin, Massachusetts and Rhode Island, for the sampling period starting $C$, August 28, 2007. BFI, base-flow index (average during the sampling period); mi, miles; UBWPAD, Upper Blackstone Water Pollution Abatement District. 
D. Sampling period starting September 24, 2007

Estimated Constituent Load

Total nitrogen phosphorus

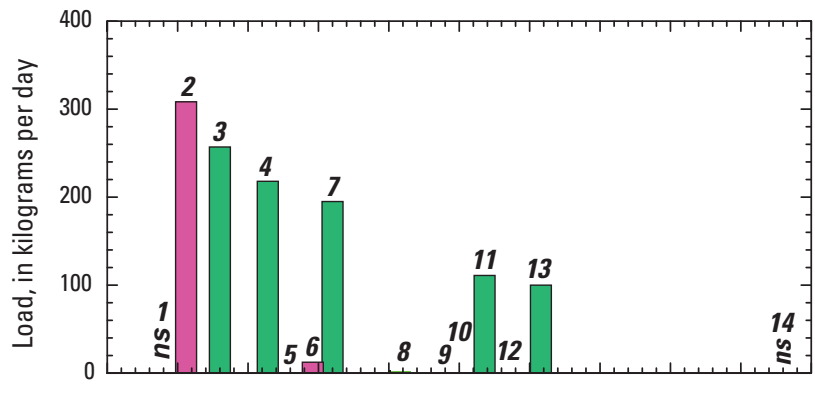

Suspended sediment
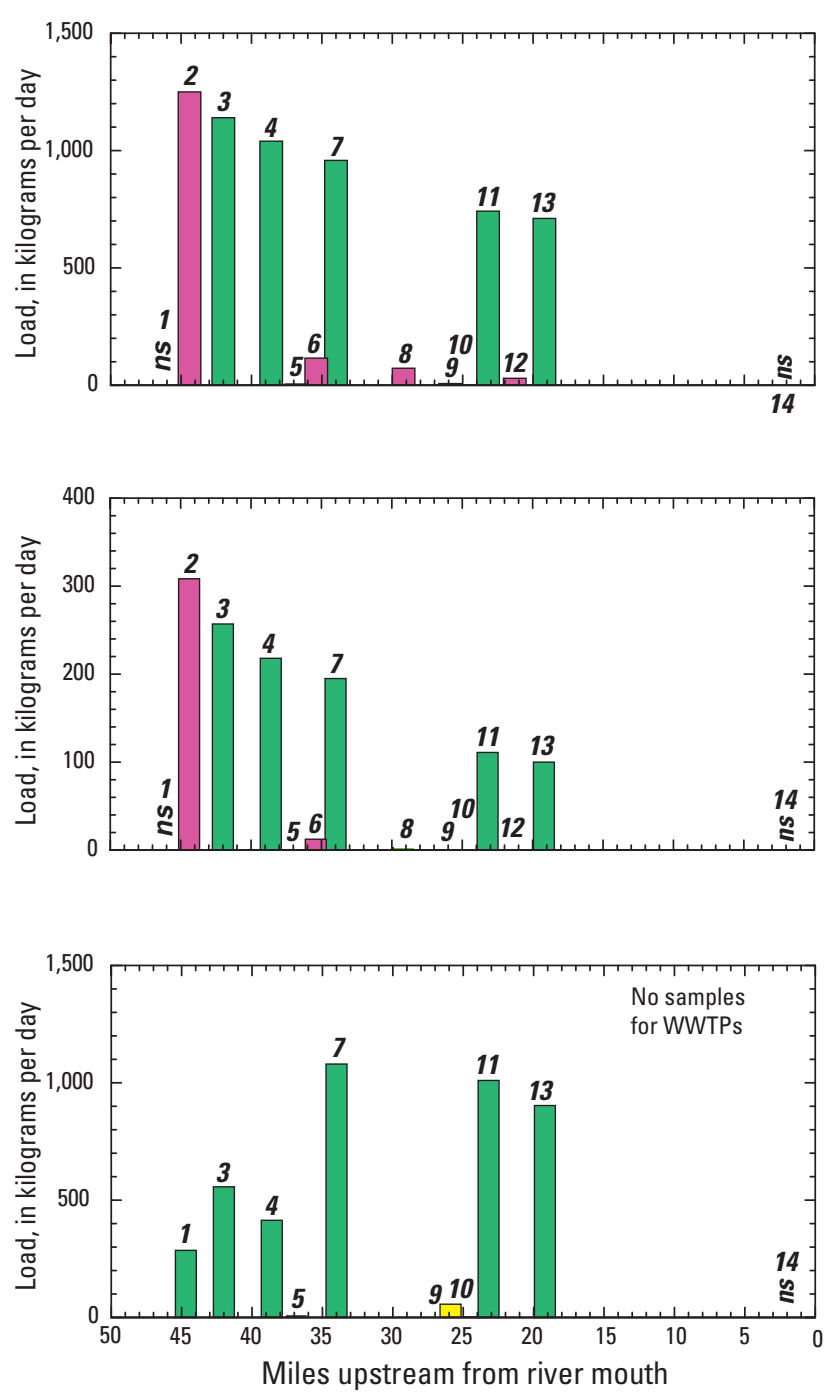

\section{EXPLANATION}

Monitoring station type

$\square$ Mainstem

Wastewater treatment plant (WWTP)

Tributary

\section{Monitoring station name}

1 Blackstone River Millbury upstream (44.7 mi) 2 UBWPAD WWTP (44.4 mi)

3 Blackstone River Millbury downstream (42.0 mi) 4 Blackstone River Wilkinsonville (38.6 mi) 5 Quinsigamond River (36.8 mi)

6 Grafton WWTP (35.4 mi)

7 Blackstone River South Grafton (34.0 mi)

8 Northbridge WWTP (29.2 mi)

9 Mumford River (25.9 mi)

10 West River (24.2 mi)

11 Blackstone River Uxbridge (23.2 mi)

12 Uxbridge WWTP (21.3 mi)

13 Blackstone River Millville (19.2 mi)

14 Blackstone River Pawcatuck (2 mi)

ns no samples

Streamflow at Blackstone River Millville station

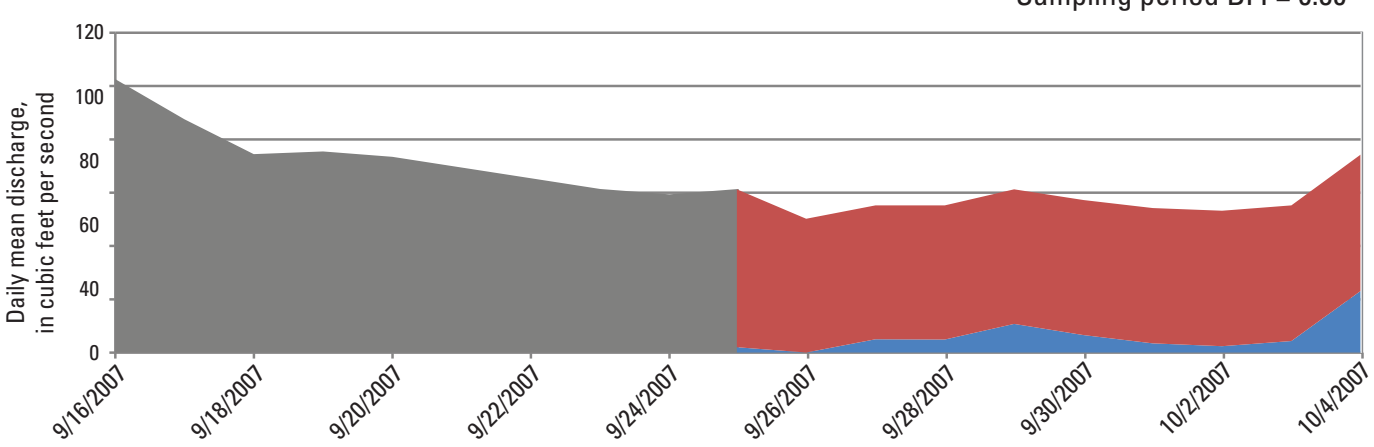

\section{EXPLANATION}

Flow component

Antecedent total flow

Sampling period runoff

Sampling period base flow

Figure 6-4. Constituent loads and streamflow at stream monitoring stations and wastewater treatment plants in the Blackstone River Basin, Massachusetts and Rhode Island, for the sampling period starting D, September 24, 2007. BFI, base-flow index (average during the sampling period); mi, miles; UBWPAD, Upper Blackstone Water Pollution Abatement District. 
E. Sampling period starting October 22, 2007

Estimated Constituent Load

Total nitrogen

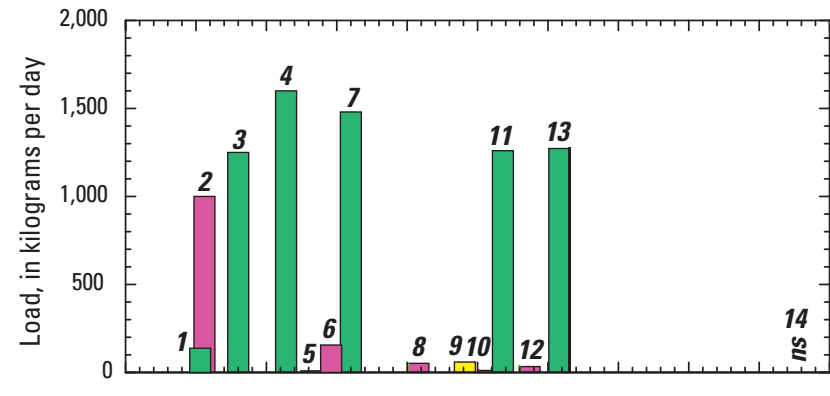

Total phosphorus

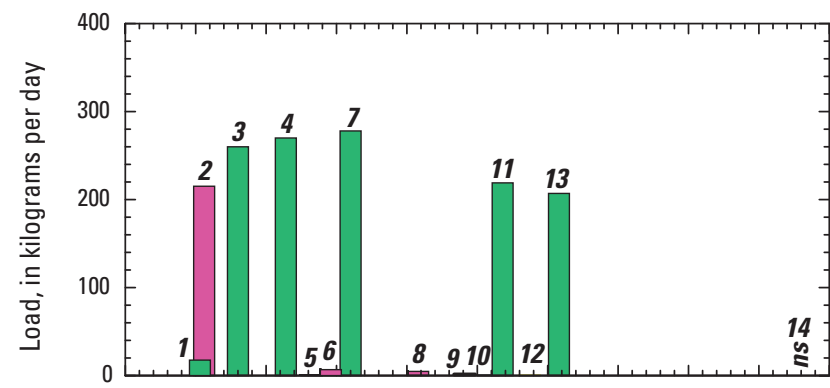

Suspended sediment

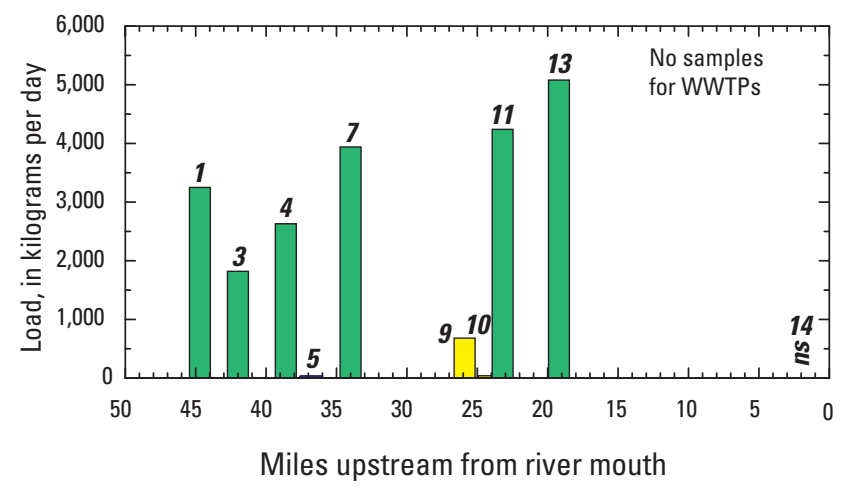

\section{EXPLANATION}

Monitoring station type

Mainstem

$\square$ Wastewater treatment plant (WWTP)

$\square$ Tributary

\section{Monitoring station name}

1 Blackstone River Millbury upstream (44.7 mi) 2 UBWPAD WWTP (44.4 mi)

3 Blackstone River Millbury downstream (42.0 mi)

4 Blackstone River Wilkinsonville (38.6 mi)

5 Quinsigamond River (36.8 mi)

6 Grafton WWTP (35.4 mi)

7 Blackstone River South Grafton (34.0 mi)

8 Northbridge WWTP (29.2 mi)

9 Mumford River (25.9 mi)

10 West River (24.2 mi)

11 Blackstone River Uxbridge (23.2 mi)

12 Uxbridge WWTP (21.3 mi)

13 Blackstone River Millville (19.2 mi)

14 Blackstone River Pawcatuck (2 mi)

ns no samples

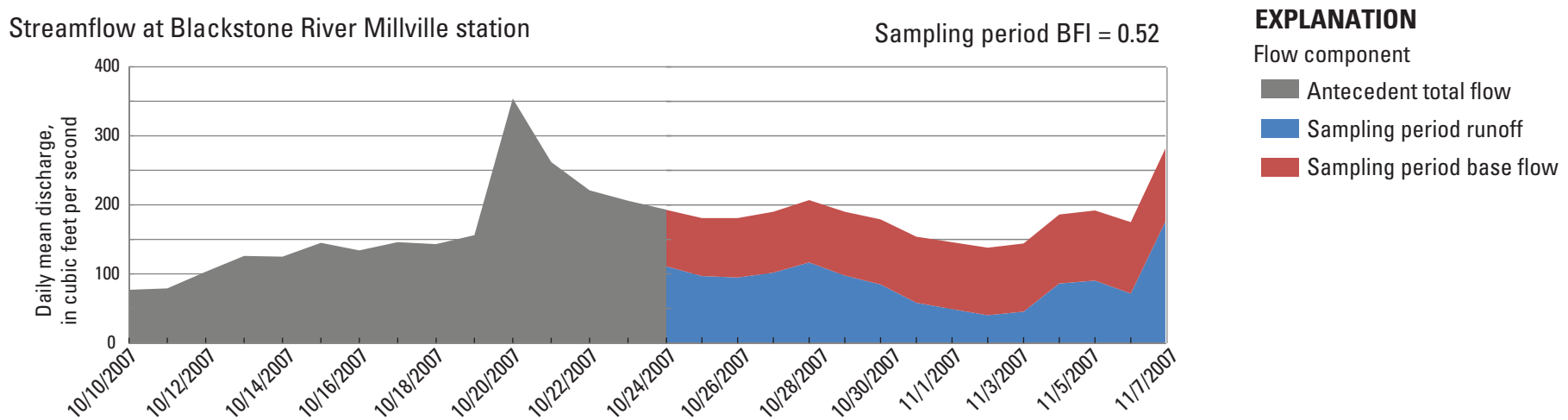

Figure 6-5. Constituent loads and streamflow at stream monitoring stations and wastewater treatment plants in the Blackstone River Basin, Massachusetts and Rhode Island, for the sampling period starting $E$, 0 ctober 22, 2007. BFI, base-flow index (average during the sampling period); mi, miles; UBWPAD, Upper Blackstone Water Pollution Abatement District. 
Estimated Constituent Load

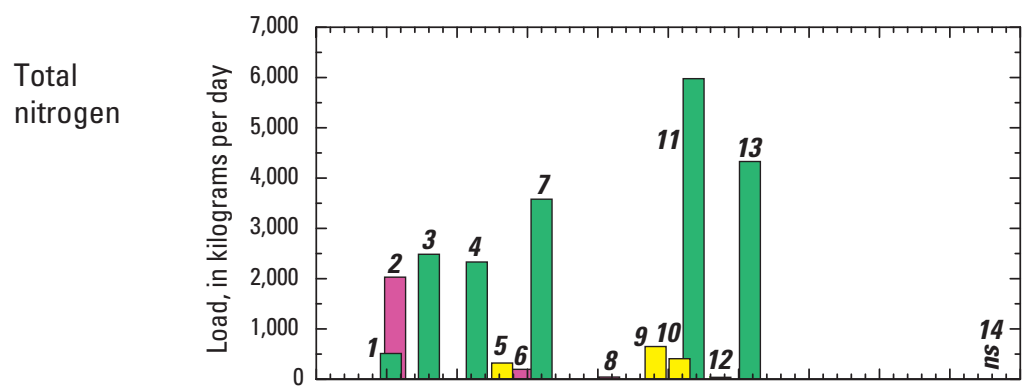

\section{EXPLANATION}

Monitoring station type

$\square$ Mainstem

Wastewater treatment plant (WWTP)

Tributary

\section{Monitoring station name}

1 Blackstone River Millbury upstream (44.7 mi) 2 UBWPAD WWTP (44.4 mi)

3 Blackstone River Millbury downstream (42.0 mi) 4 Blackstone River Wilkinsonville (38.6 mi) 5 Quinsigamond River (36.8 mi)

6 Grafton WWTP (35.4 mi)

Total

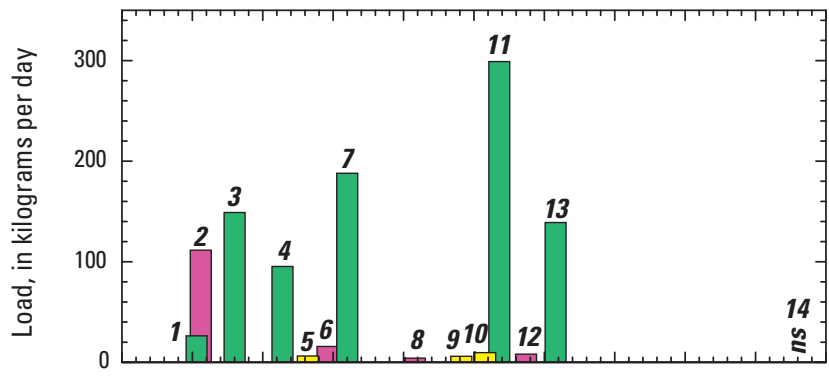

7 Blackstone River South Grafton (34.0 mi)

8 Northbridge WWTP (29.2 mi)

9 Mumford River (25.9 mi)

10 West River (24.2 mi)

11 Blackstone River Uxbridge (23.2 mi)

12 Uxbridge WWTP (21.3 mi)

13 Blackstone River Millville (19.2 mi)

14 Blackstone River Pawcatuck (2 mi)

ns no samples

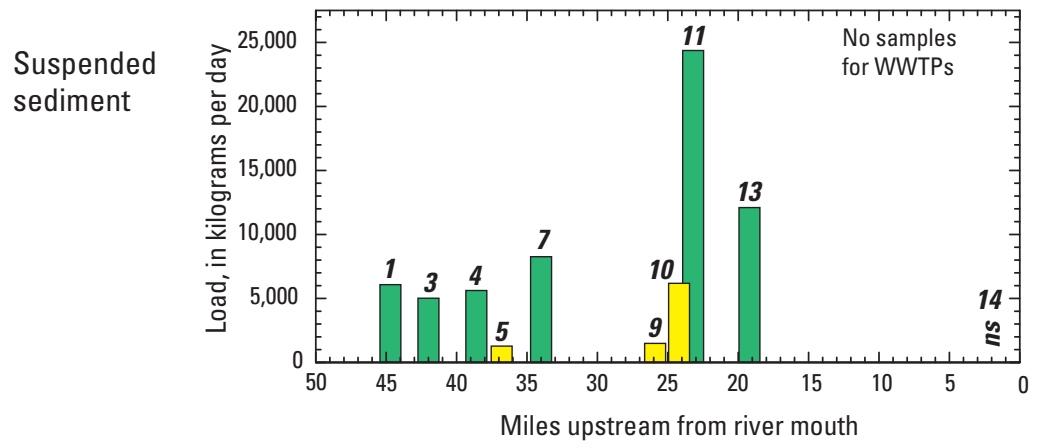

Streamflow at Blackstone River Millville station

Sampling period $\mathrm{BFI}=0.79$

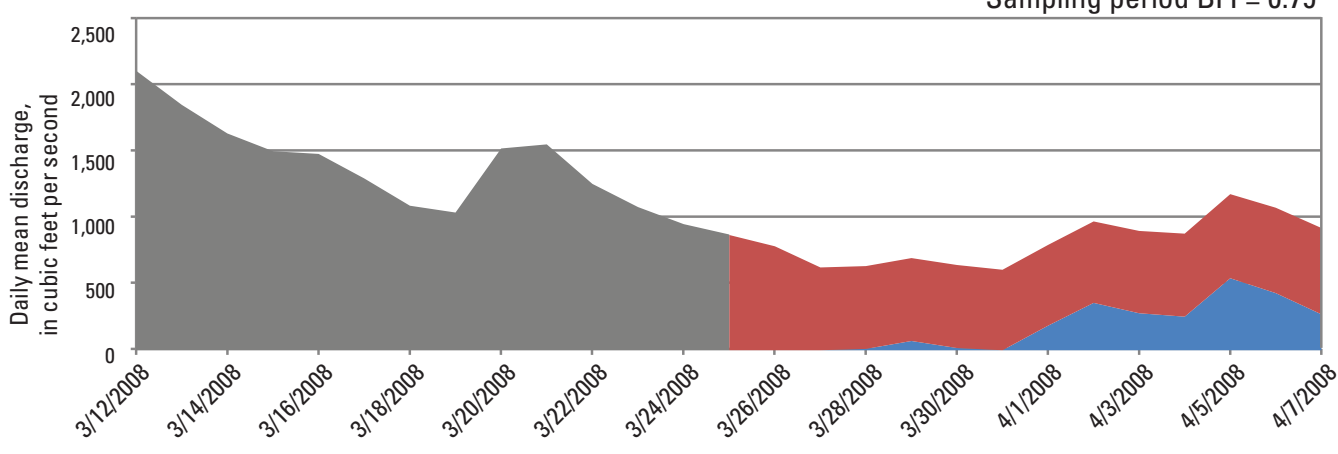

\section{EXPLANATION}

Flow component

Antecedent total flow

Sampling period runoff

Sampling period base flow

Figure 6-6. Constituent loads and streamflow at steam monitoring stations and wastewater treatment plants in the Blackstone River Basin, Massachusetts and Rhode Island, for the sampling period starting $F$, March 22, 2008. BFI, base-flow index (average during the sampling period); mi, miles; UBWPAD, Upper Blackstone Water Pollution Abatement District. 
G. Sampling period starting April 28, 2008

Estimated Constituent Load

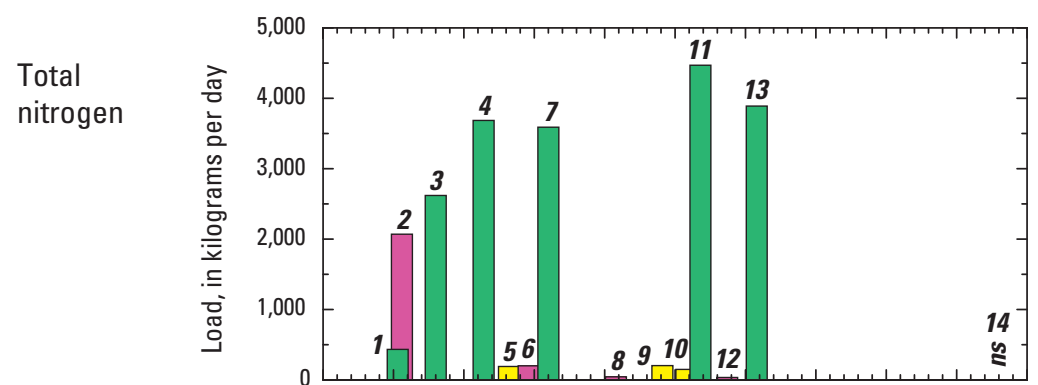

Total phosphorus
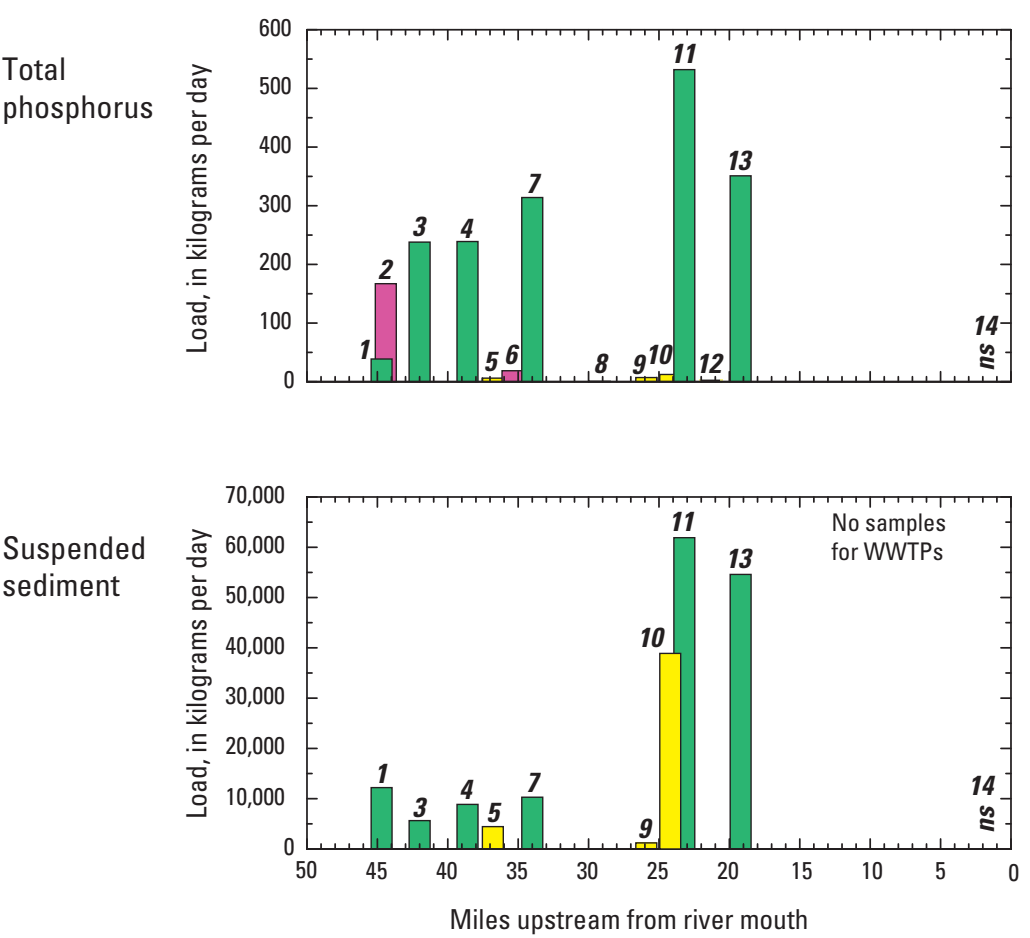

\section{EXPLANATION}

Monitoring station type

$\square$ Mainstem

Wastewater treatment plant (WWTP)

$\square$ Tributary

\section{Monitoring station name}

1 Blackstone River Millbury upstream (44.7 mi) 2 UBWPAD WWTP (44.4 mi)

3 Blackstone River Millbury downstream (42.0 mi)

4 Blackstone River Wilkinsonville (38.6 mi)

5 Quinsigamond River (36.8 mi)

6 Grafton WWTP (35.4 mi)

7 Blackstone River South Grafton (34.0 mi)

8 Northbridge WWTP (29.2 mi)

9 Mumford River (25.9 mi)

10 West River (24.2 mi)

11 Blackstone River Uxbridge (23.2 mi)

12 Uxbridge WWTP (21.3 mi)

13 Blackstone River Millville (19.2 mi)

14 Blackstone River Pawcatuck (2 mi)

ns no samples
Streamflow at Blackstone River Millville station

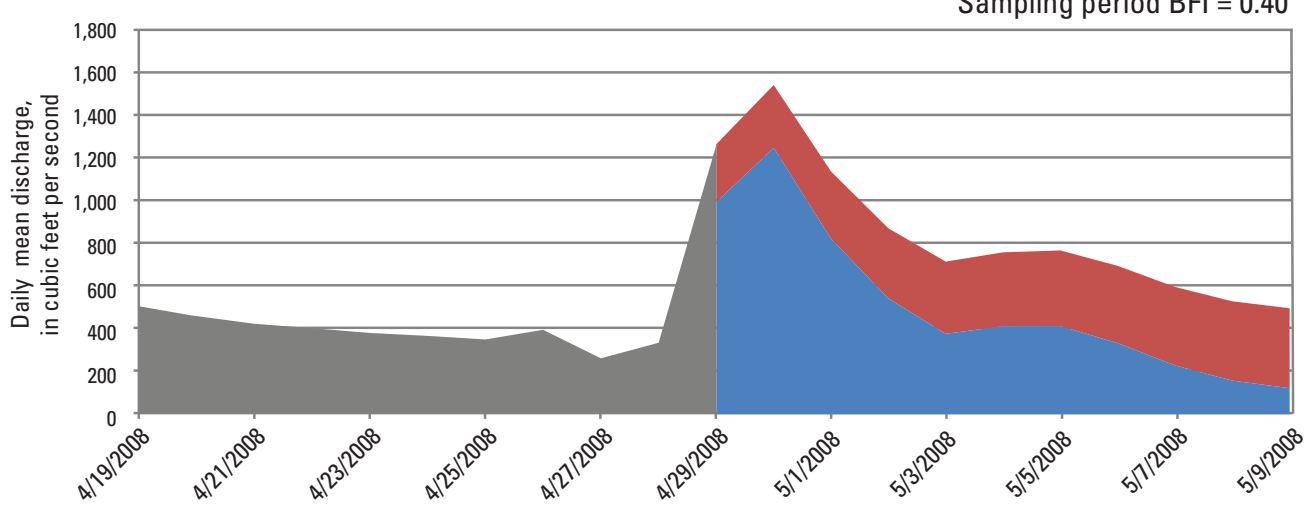

\section{EXPLANATION}

Flow component

Antecedent total flow

Sampling period runoff

Sampling period base flow

Figure 6-7. Constituent loads and streamflow at stream monitoring stations and wastewater treatment plants in the Blackstone River Basin, Massachusetts and Rhode Island, for the sampling period starting G, April 28, 2008. BFl, base-flow index (average during the sampling period); mi, miles; UBWPAD, Upper Blackstone Water Pollution Abatement District. 
H. Sampling period starting May 27, 2008

Estimated Constituent Load

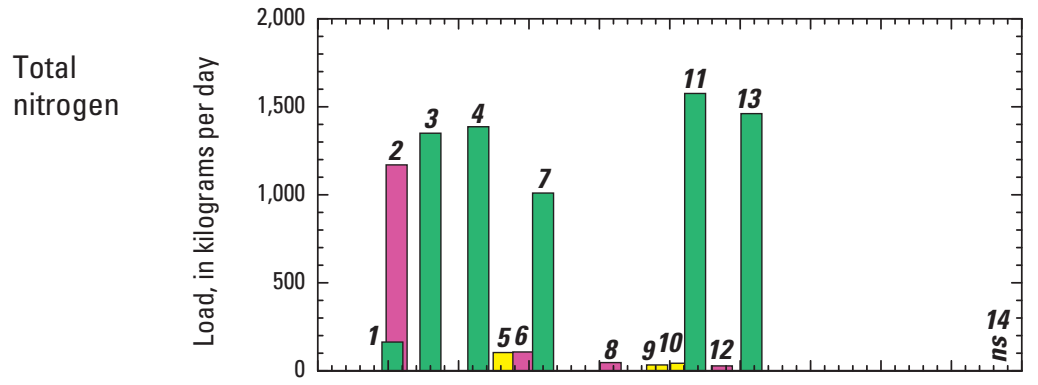

\section{EXPLANATION}

Monitoring station type

Mainstem

Wastewater treatment plant (WWTP)

$\square$ Tributary

\section{Monitoring station name}

1 Blackstone River Millbury upstream (44.7 mi) 2 UBWPAD WWTP (44.4 mi)

3 Blackstone River Millbury downstream (42.0 mi)

4 Blackstone River Wilkinsonville (38.6 mi)

5 Quinsigamond River (36.8 mi)

6 Grafton WWTP (35.4 mi)

7 Blackstone River South Grafton (34.0 mi)

8 Northbridge WWTP (29.2 mi)

9 Mumford River (25.9 mi)

10 West River (24.2 mi)

11 Blackstone River Uxbridge (23.2 mi)

12 Uxbridge WWTP (21.3 mi)

13 Blackstone River Millville (19.2 mi)

14 Blackstone River Pawcatuck (2 mi)

ns no samples

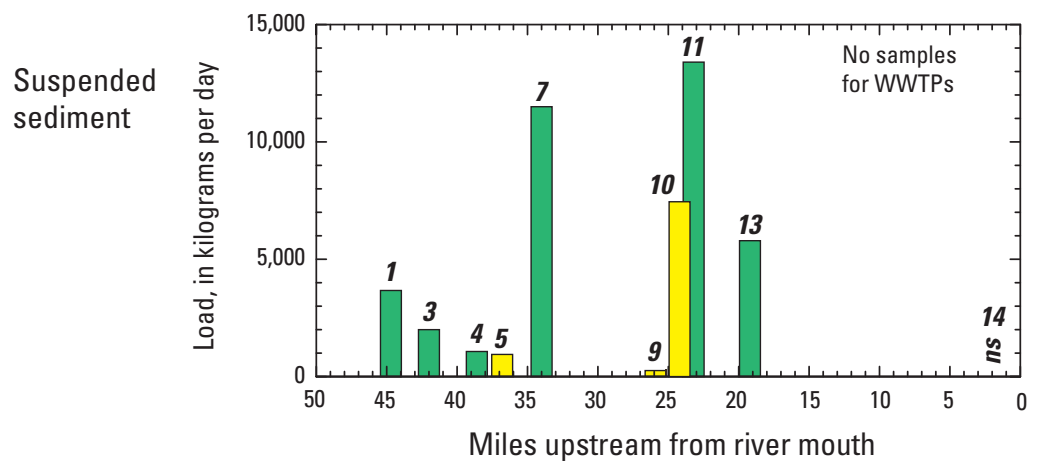

Streamflow at Blackstone River Millville station

Sampling period $\mathrm{BFI}=0.92$

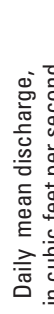

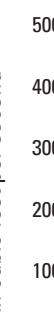

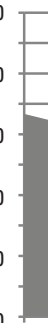

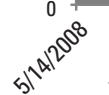
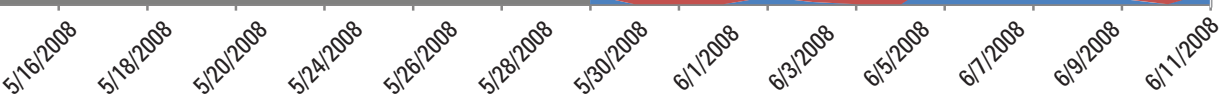

Figure 6-8. Constituent loads and streamflow at stream monitoring stations and wastewater treatment plants in the Blackstone River Basin, Massachusetts and Rhode Island, for the sampling period starting $H$, May 27, 2008. BFI, base-flow index (average during the sampling period); mi, miles; UBWPAD, Upper Blackstone Water Pollution Abatement District. 
I. Sampling period starting June 11, 2008

Estimated Constituent Load

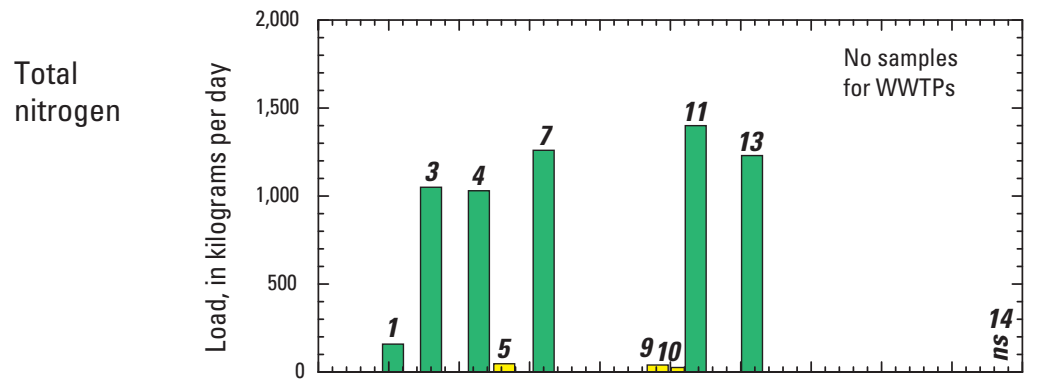

Total phosphorus

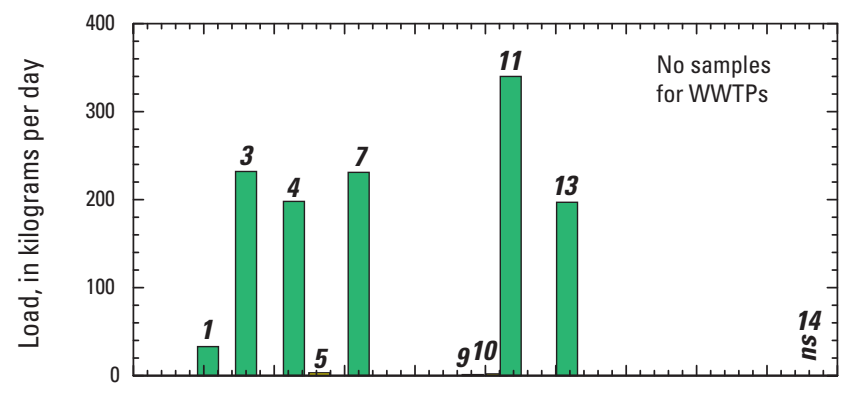

\section{EXPLANATION}

\section{Monitoring station type}

$\square$ Mainstem

Wastewater treatment plant (WWTP)

$\square$ Tributary

\section{Monitoring station name}

1 Blackstone River Millbury upstream (44.7 mi) 2 UBWPAD WWTP (44.4 mi)

3 Blackstone River Millbury downstream (42.0 mi)

4 Blackstone River Wilkinsonville (38.6 mi)

5 Quinsigamond River (36.8 mi)

6 Grafton WWTP (35.4 mi)

7 Blackstone River South Grafton (34.0 mi)

8 Northbridge WWTP (29.2 mi)

9 Mumford River (25.9 mi)

10 West River (24.2 mi)

11 Blackstone River Uxbridge (23.2 mi)

12 Uxbridge WWTP (21.3 mi)

13 Blackstone River Millville (19.2 mi)

14 Blackstone River Pawcatuck (2 mi)

ns no samples
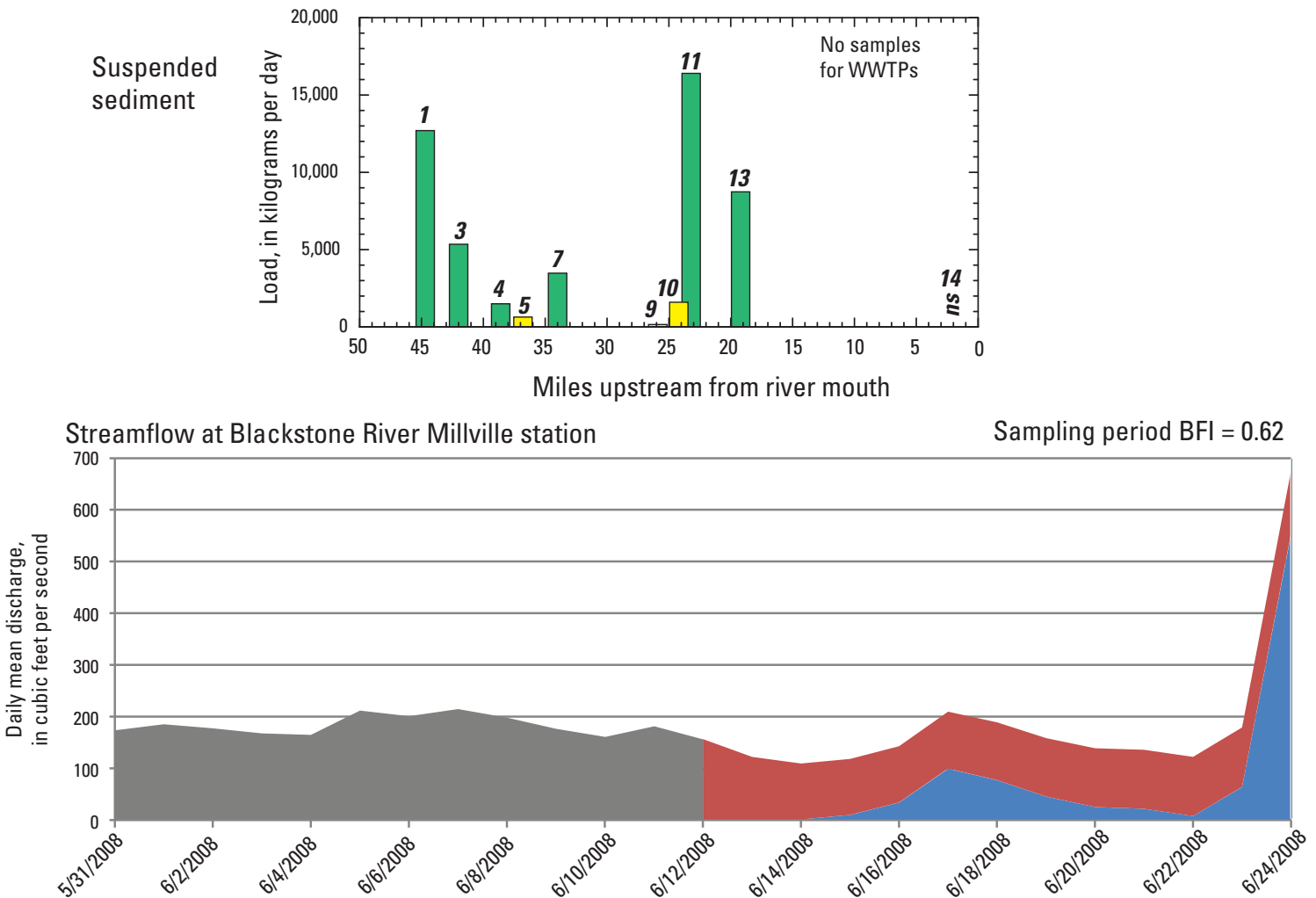

\section{EXPLANATION}

Flow component

Antecedent total flow

Sampling period runoff

Sampling period base flow

Figure 6-9. Constituent loads and streamflow at stream monitoring stations and wastewater treatment plants in the Blackstone River Basin, Massachusetts and Rhode Island, for the sampling period starting I, June 11, 2008. BFI, base-flow index (average during the sampling period); mi, miles; UBWPAD, Upper Blackstone Water Pollution Abatement District. 
Estimated Constituent Load

Total nitrogen

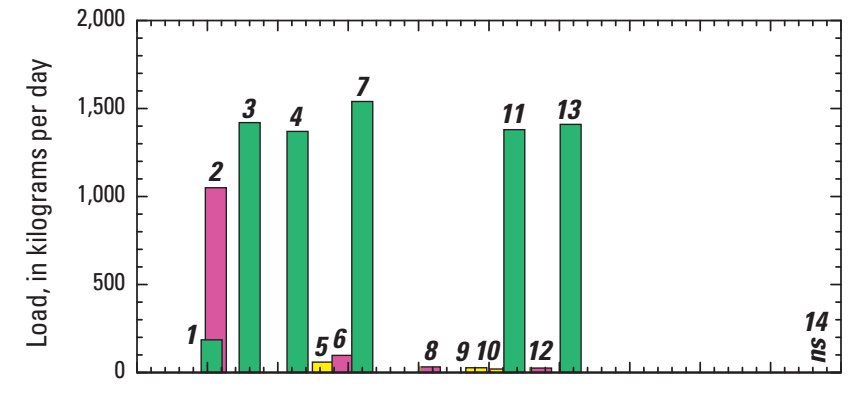

Total phosphorus

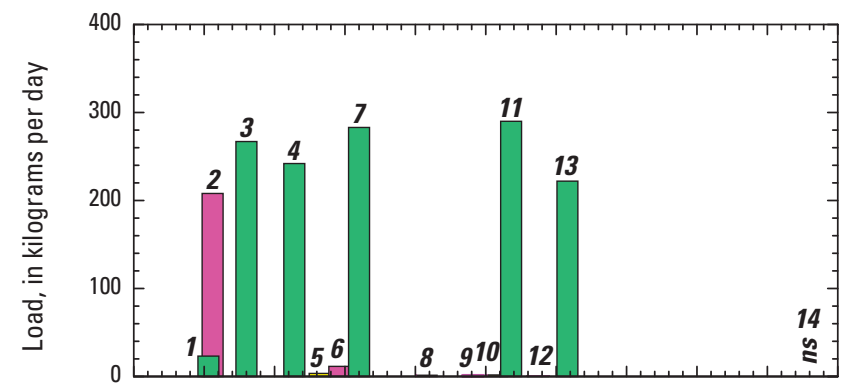

\section{EXPLANATION}

Monitoring station type

$\square$ Mainstem

Wastewater treatment plant (WWTP)

Tributary

\section{Monitoring station name}

1 Blackstone River Millbury upstream (44.7 mi) 2 UBWPAD WWTP (44.4 mi)

3 Blackstone River Millbury downstream (42.0 mi)

4 Blackstone River Wilkinsonville (38.6 mi)

5 Quinsigamond River (36.8 mi)

6 Grafton WWTP (35.4 mi)

7 Blackstone River South Grafton (34.0 mi)

8 Northbridge WWTP (29.2 mi)

9 Mumford River (25.9 mi)

10 West River (24.2 mi)

11 Blackstone River Uxbridge (23.2 mi)

12 Uxbridge WWTP (21.3 mi)

13 Blackstone River Millville (19.2 mi)

14 Blackstone River Pawcatuck (2 mi)

ns no samples

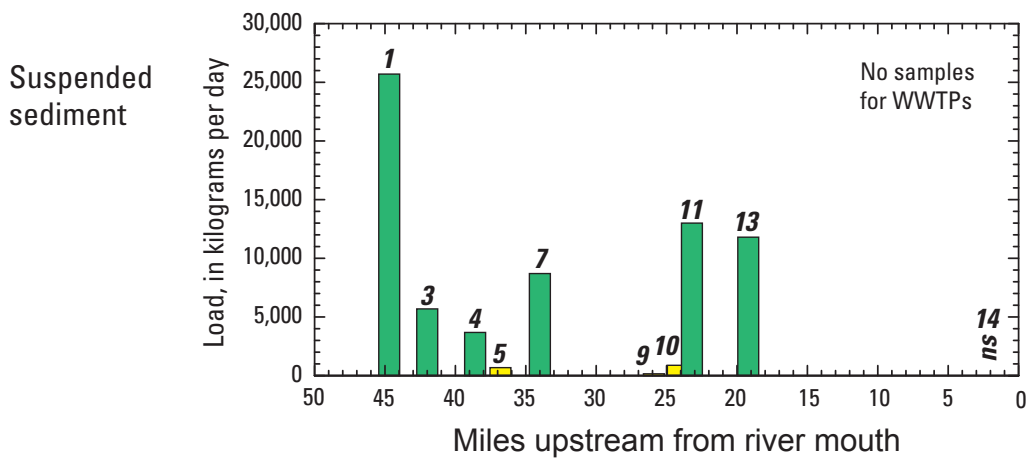

Streamflow at Blackstone River Millville station

Sampling period $\mathrm{BFI}=0.62$

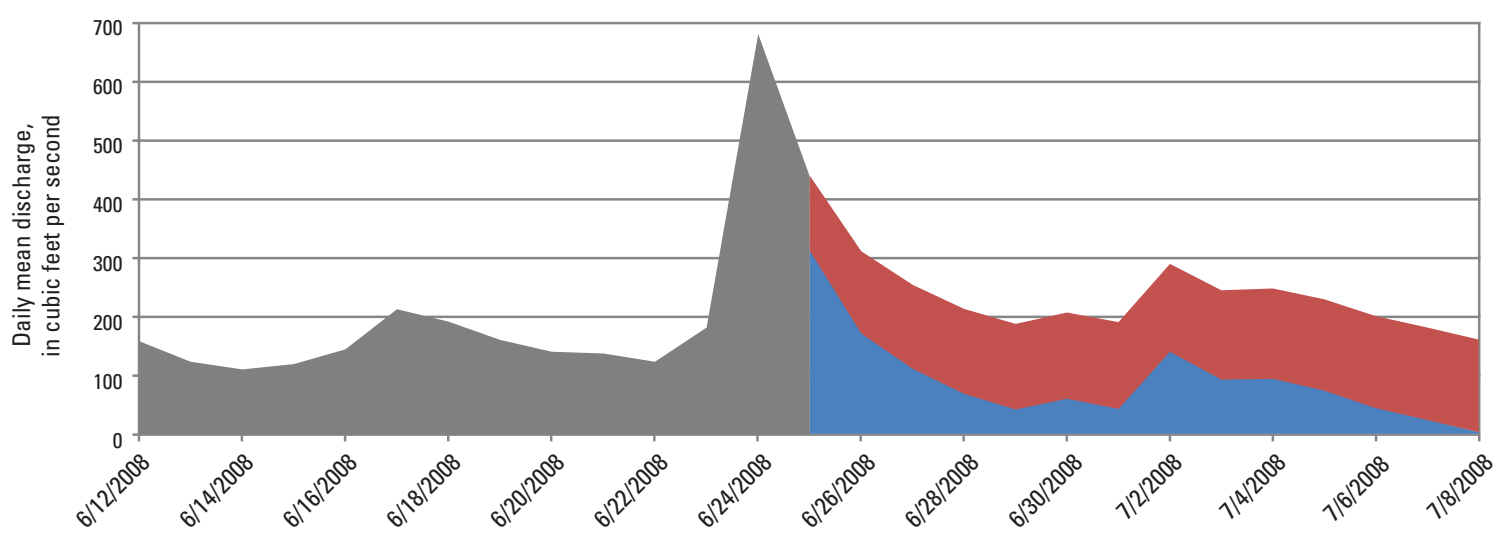

\section{EXPLANATION}

Flow component

Antecedent total flow

Sampling period runoff

Sampling period base flow

Figure 6-10. Constituent loads and streamflow at stream monitoring stations and wastewater treatment plants in the Blackstone River Basin, Massachusetts and Rhode Island, for the sampling period starting $J$, June 24, 2008. BFI, base-flow index (average during the sampling period); mi, miles; UBWPAD, Upper Blackstone Water Pollution Abatement District. 
K. Sampling period starting July 8, 2008

Estimated Constituent Load

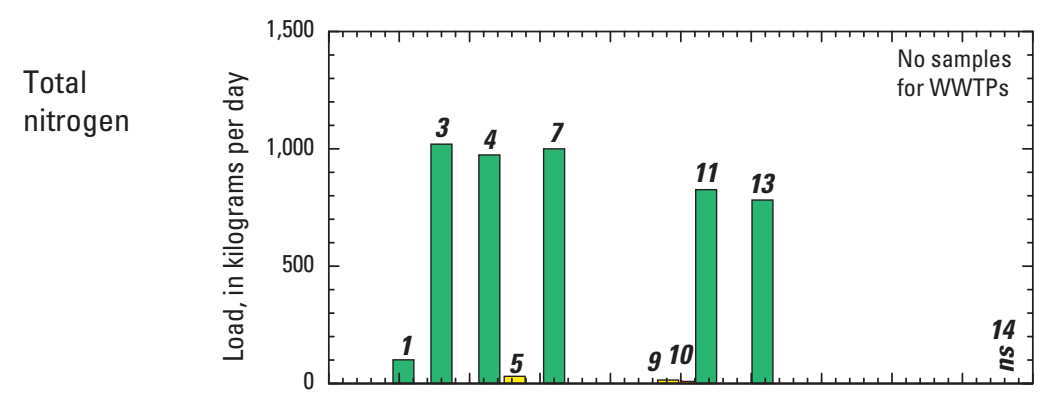

Total phosphorus
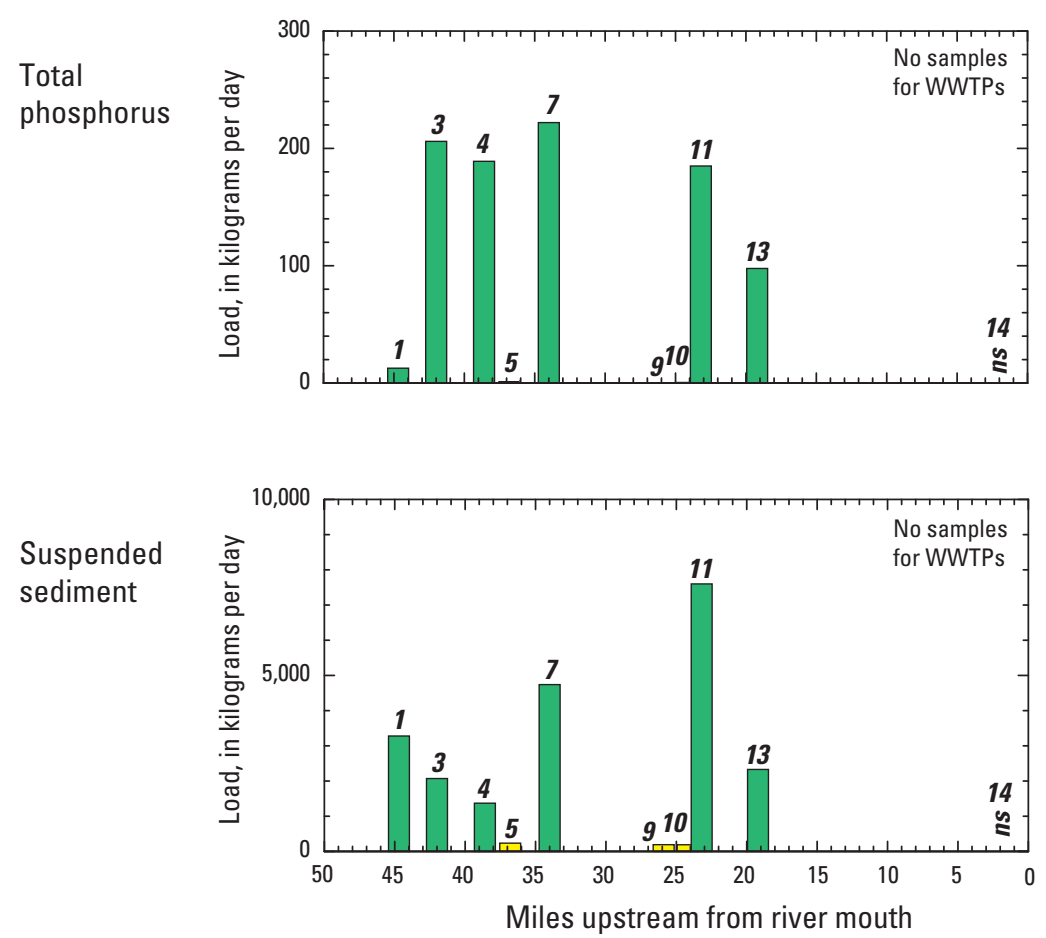

\section{EXPLANATION}

Monitoring station type

$\square$ Mainstem

Wastewater treatment plant (WWTP)

$\square$ Tributary

\section{Monitoring station name}

1 Blackstone River Millbury upstream (44.7 mi) 2 UBWPAD WWTP (44.4 mi)

3 Blackstone River Millbury downstream (42.0 mi)

4 Blackstone River Wilkinsonville (38.6 mi)

5 Quinsigamond River (36.8 mi)

6 Grafton WWTP (35.4 mi)

7 Blackstone River South Grafton (34.0 mi)

8 Northbridge WWTP (29.2 mi)

9 Mumford River (25.9 mi)

10 West River (24.2 mi)

11 Blackstone River Uxbridge (23.2 mi)

12 Uxbridge WWTP (21.3 mi)

13 Blackstone River Millville (19.2 mi)

14 Blackstone River Pawcatuck (2 mi)

ns no samples

Streamflow at Blackstone River Millville station

Sampling period $\mathrm{BFI}=0.86$

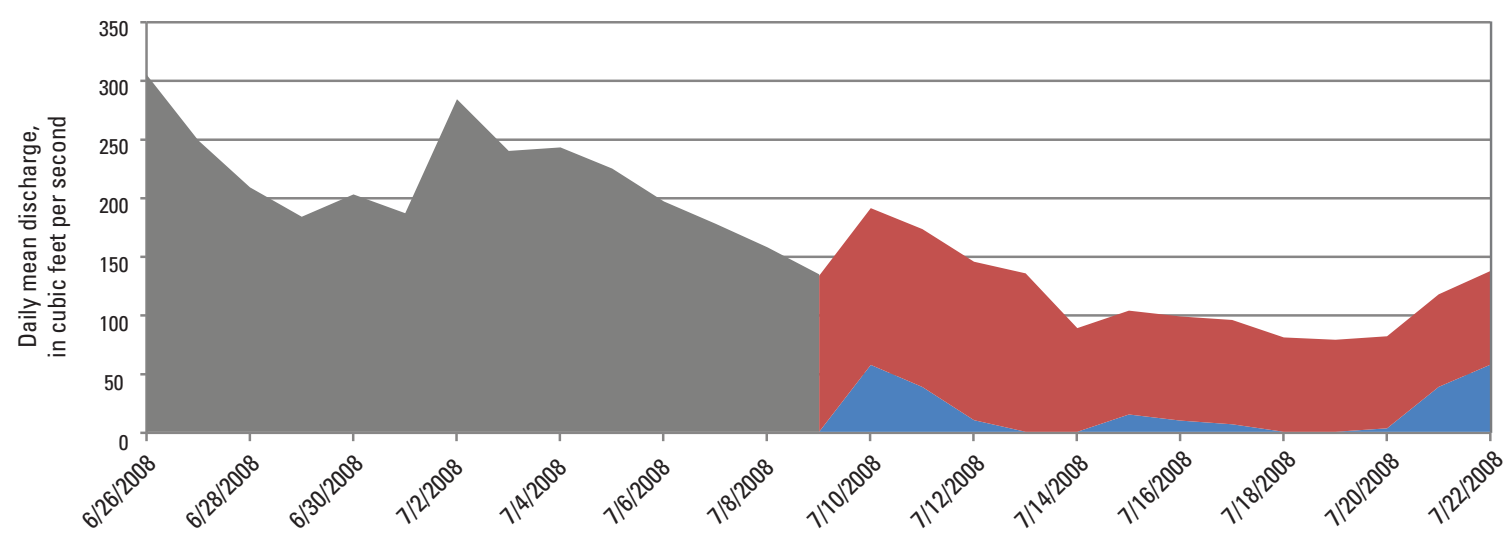

EXPLANATION

Flow component

Antecedent total flow

Sampling period runoff

Sampling period base flow

Figure 6-11. Constituent loads and streamflow at stream monitoring stations and wastewater treatment plants in the Blackstone River Basin, Massachusetts and Rhode Island, for the sampling period starting $K$, July 8, 2008. BFI, base-flow index (average during the sampling period); mi, miles; UBWPAD, Upper Blackstone Water Pollution Abatement District. 
L. Sampling period starting July 22, 2008

Estimated Constituent Load

Total nitrogen

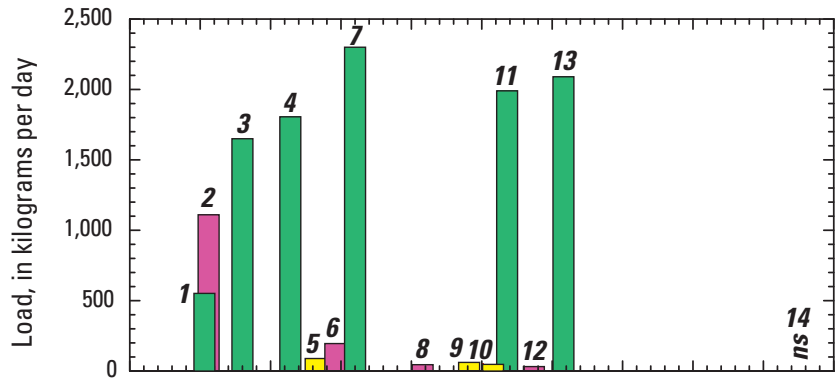

Total phosphorus
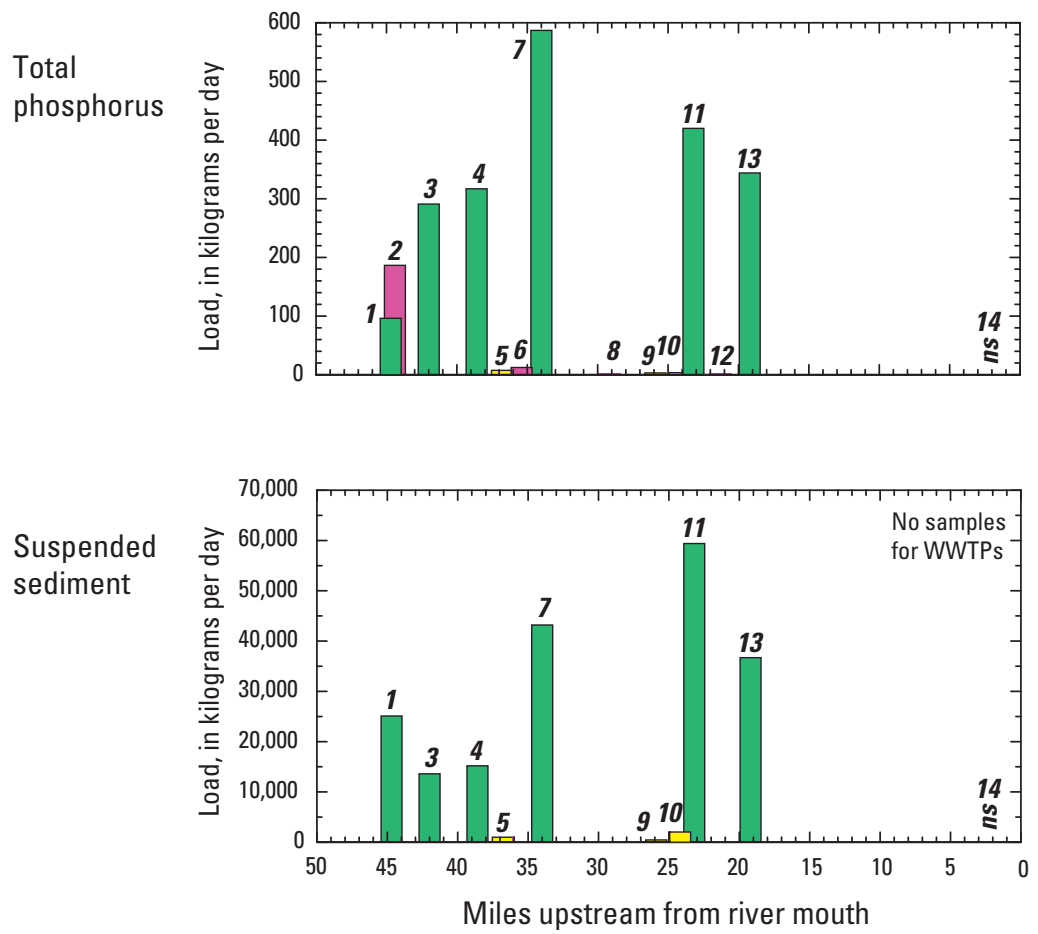

\section{EXPLANATION}

\section{Monitoring station type}

$\square$ Mainstem

Wastewater treatment plant (WWTP)

Tributary

\section{Monitoring station name}

1 Blackstone River Millbury upstream (44.7 mi) 2 UBWPAD WWTP (44.4 mi)

3 Blackstone River Millbury downstream (42.0 mi)

4 Blackstone River Wilkinsonville (38.6 mi)

5 Quinsigamond River (36.8 mi)

6 Grafton WWTP (35.4 mi)

7 Blackstone River South Grafton (34.0 mi)

8 Northbridge WWTP (29.2 mi)

9 Mumford River (25.9 mi)

10 West River (24.2 mi)

11 Blackstone River Uxbridge (23.2 mi)

12 Uxbridge WWTP (21.3 mi)

13 Blackstone River Millville (19.2 mi)

14 Blackstone River Pawcatuck (2 mi)

ns no samples

Streamflow at Blackstone River Millville station

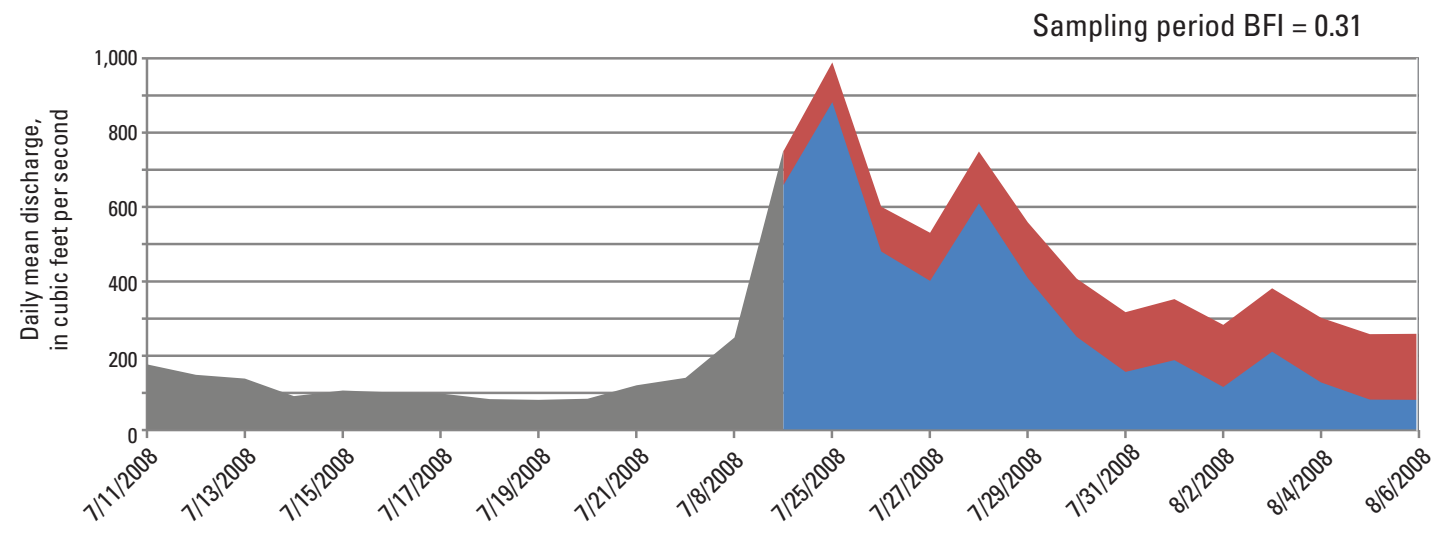

EXPLANATION

Flow component

Antecedent total flow

Sampling period runoff

Sampling period base flow

Figure 6-12. Constituent loads and streamflow at stream monitoring stations and wastewater treatment plants in the Blackstone River Basin, Massachusetts and Rhode Island, for the sampling period starting $L$, July 22, 2008. BFI, base-flow index (average during the sampling period); mi, miles; UBWPAD, Upper Blackstone Water Pollution Abatement District. 
M. Sampling period starting August 5, 2008

Estimated Constituent Load

Total nitrogen

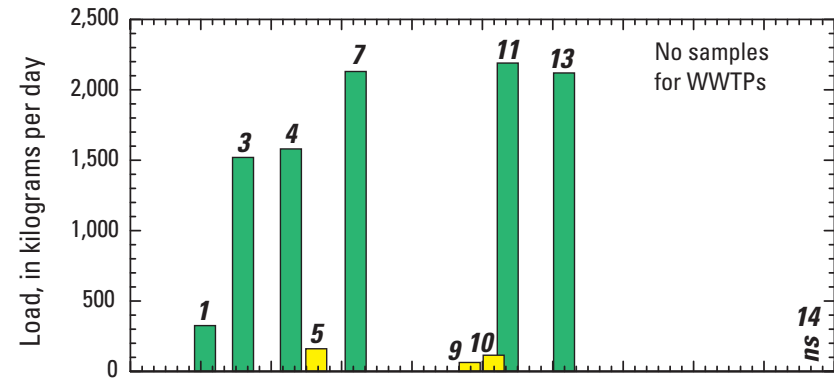

Total phosphorus
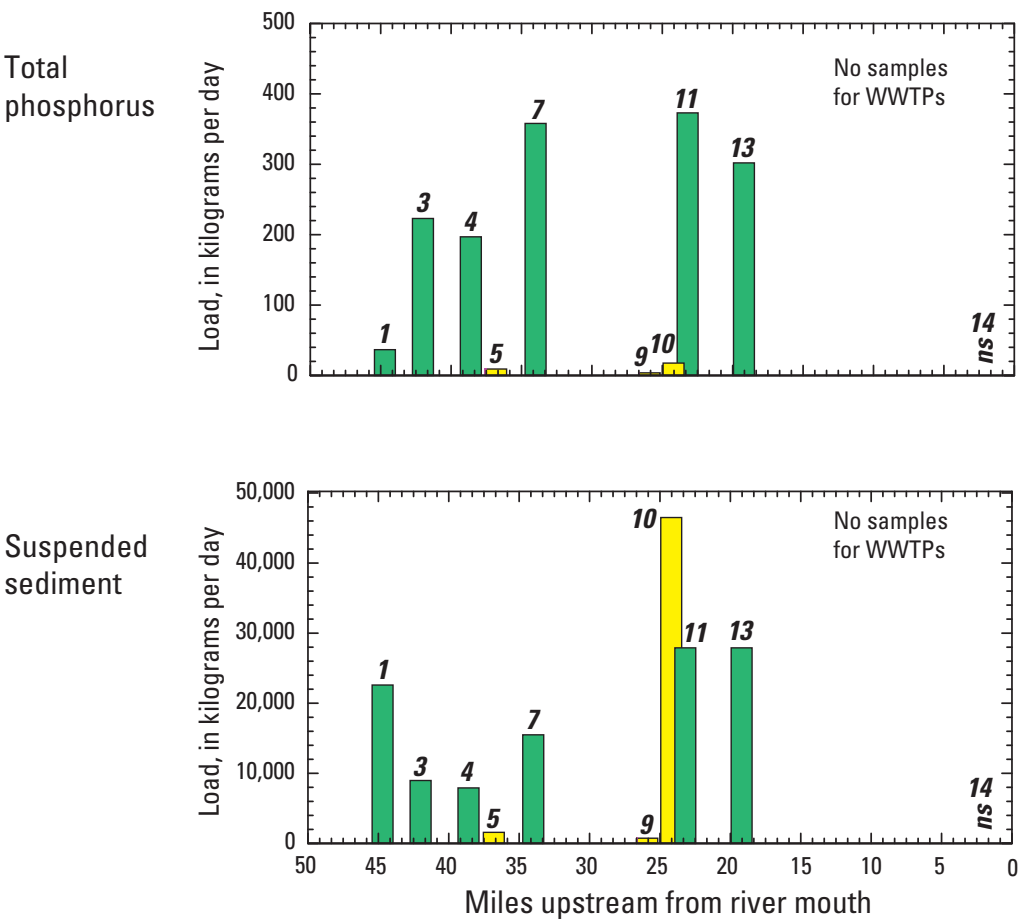

\section{EXPLANATION}

\section{Monitoring station type}

$\square$ Mainstem

Wastewater treatment plant (WWTP)

Tributary

\section{Monitoring station name}

1 Blackstone River Millbury upstream (44.7 mi) 2 UBWPAD WWTP (44.4 mi)

3 Blackstone River Millbury downstream (42.0 mi)

4 Blackstone River Wilkinsonville (38.6 mi)

5 Quinsigamond River (36.8 mi)

6 Grafton WWTP (35.4 mi)

7 Blackstone River South Grafton (34.0 mi)

8 Northbridge WWTP $(29.2 \mathrm{mi})$

9 Mumford River (25.9 mi)

10 West River (24.2 mi)

11 Blackstone River Uxbridge (23.2 mi)

12 Uxbridge WWTP (21.3 mi)

13 Blackstone River Millville (19.2 mi)

14 Blackstone River Pawcatuck (2 mi)

ns no samples
Streamflow at Blackstone River Millville station

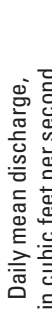

Sampling period $\mathrm{BFI}=0.41$

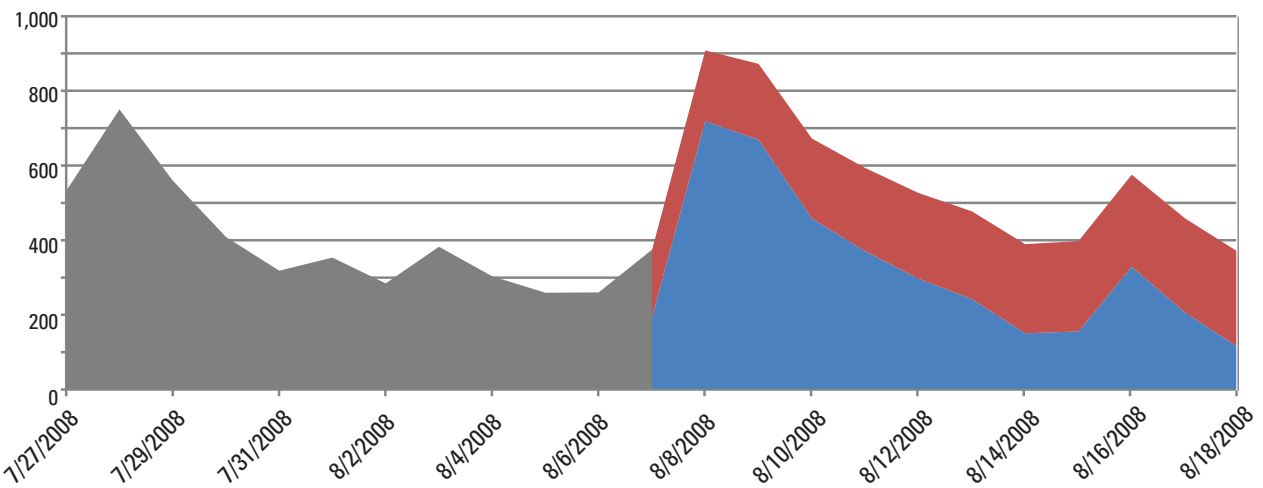

\section{EXPLANATION}

Flow component

Antecedent total flow

Sampling period runoff

Sampling period base flow

Figure 6-13. Constituent loads and streamflow at stream monitoring stations and wastewater treatment plants in the Blackstone River Basin, Massachusetts and Rhode Island, for the sampling period starting $M$, August 5, 2008. BFI, base-flow index (average during the sampling period); mi, miles; UBWPAD, Upper Blackstone Water Pollution Abatement District. 
N. Sampling period starting August 19, 2008

Estimated Constituent Load

Total nitrogen

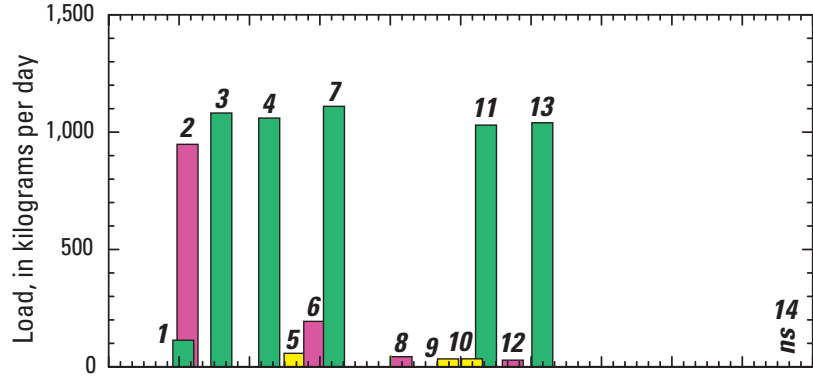

Total phosphorus

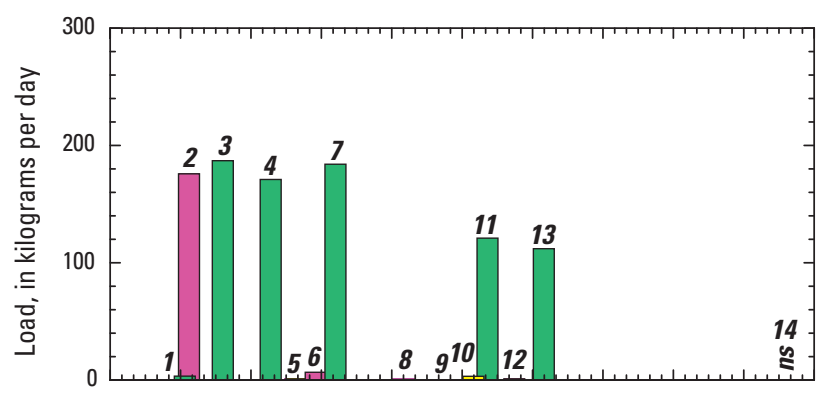

Suspended sediment

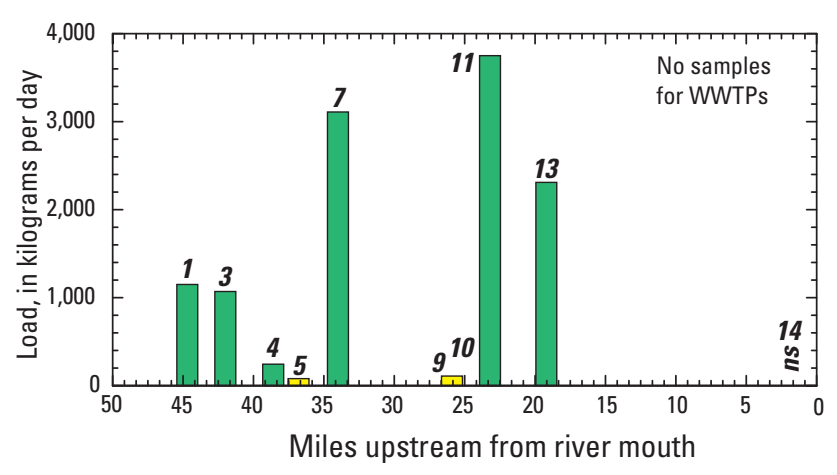

\section{EXPLANATION}

Monitoring station type

Mainstem

Wastewater treatment plant (WWTP)

Tributary

\section{Monitoring station name}

1 Blackstone River Millbury upstream (44.7 mi)

2 UBWPAD WWTP (44.4 mi)

3 Blackstone River Millbury downstream (42.0 mi)

4 Blackstone River Wilkinsonville (38.6 mi)

5 Quinsigamond River (36.8 mi)

6 Grafton WWTP (35.4 mi)

7 Blackstone River South Grafton (34.0 mi)

8 Northbridge WWTP (29.2 mi)

9 Mumford River (25.9 mi)

10 West River (24.2 mi)

11 Blackstone River Uxbridge (23.2 mi)

12 Uxbridge WWTP (21.3 mi)

13 Blackstone River Millville (19.2 mi)

14 Blackstone River Pawcatuck (2 mi)

ns no samples

Streamflow at Blackstone River Millville station

\section{Sampling period BFI $=0.99 \quad$ EXPLANATION}

Flow component

Antecedent total flow

Sampling period runoff

Sampling period base flow

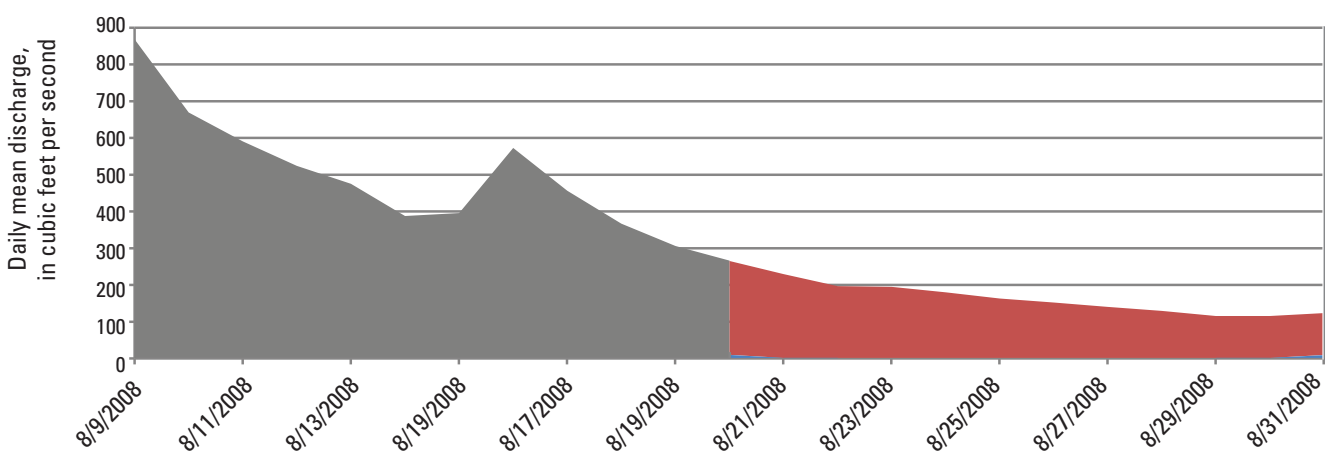

Figure 6-14. Constituent loads and streamflow at stream monitoring stations and wastewater treatment plants in the Blackstone River Basin, Massachusetts and Rhode Island, for the sampling period starting N, August 19, 2008. BFI, base-flow index (average during the sampling period); mi, miles; UBWPAD, Upper Blackstone Water Pollution Abatement District. 
O. Sampling period starting September 2, 2008

Estimated Constituent Load

Total nitrogen

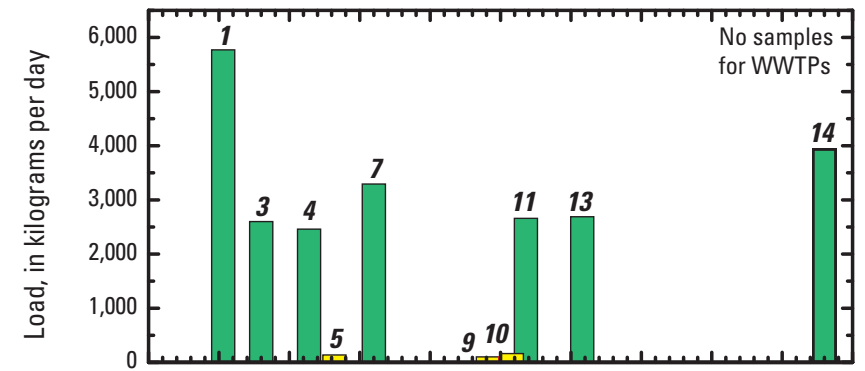

Total phosphorus
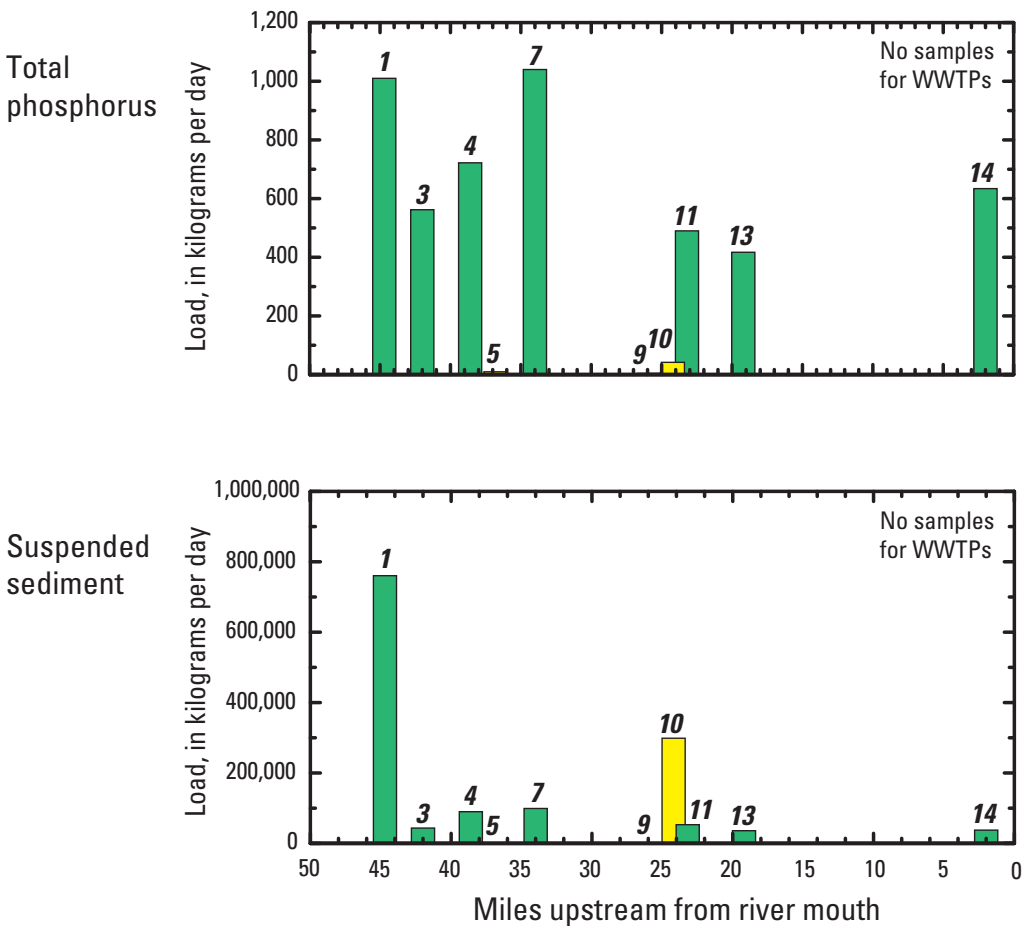

\section{EXPLANATION}

Monitoring station type

$\square$ Mainstem

Wastewater treatment plant (WWTP)

$\square$ Tributary

\section{Monitoring station name}

1 Blackstone River Millbury upstream (44.7 mi) 2 UBWPAD WWTP (44.4 mi)

3 Blackstone River Millbury downstream (42.0 mi)

4 Blackstone River Wilkinsonville (38.6 mi)

5 Quinsigamond River (36.8 mi)

6 Grafton WWTP (35.4 mi)

7 Blackstone River South Grafton (34.0 mi)

8 Northbridge WWTP (29.2 mi)

9 Mumford River (25.9 mi)

10 West River (24.2 mi)

11 Blackstone River Uxbridge (23.2 mi)

12 Uxbridge WWTP (21.3 mi)

13 Blackstone River Millville (19.2 mi)

14 Blackstone River Pawcatuck (2 mi)

$n \boldsymbol{s}$ no samples
Streamflow at Blackstone River Millville station

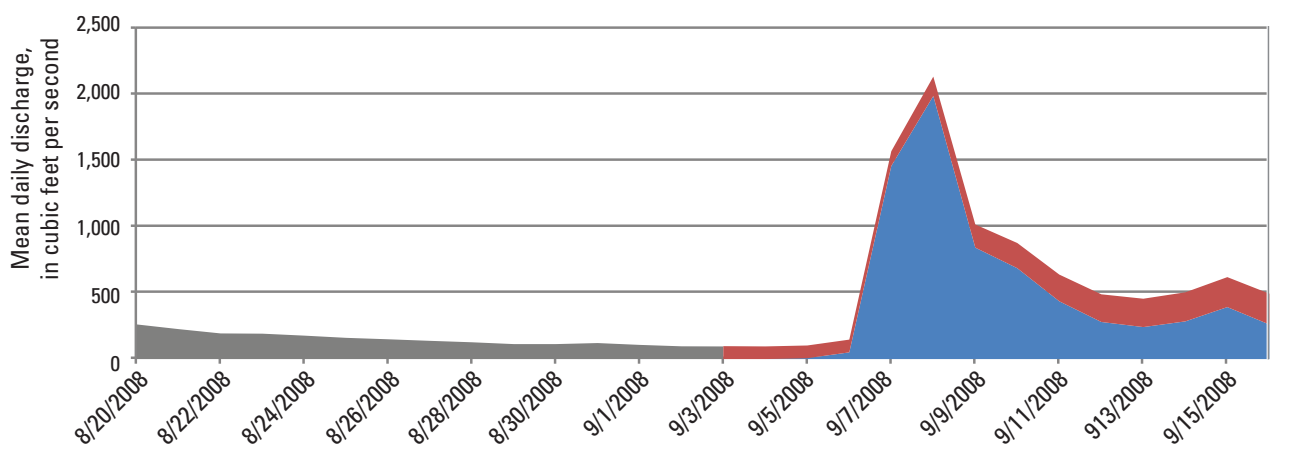

\section{EXPLANATION}

Flow component

Antecedent total flow

Sampling period runoff

Sampling period base flow

Figure 6-15. Constituent loads and streamflow at stream monitoring stations and wastewater treatment plants in the Blackstone River Basin, Massachusetts and Rhode Island, for the sampling period starting 0, September 2, 2008. BFI, base-flow index (average during the sampling period); mi, miles; UBWPAD, Upper Blackstone Water Pollution Abatement District. 
P. Sampling period starting September 16, 2008

Estimated Constituent Load

Total nitrogen

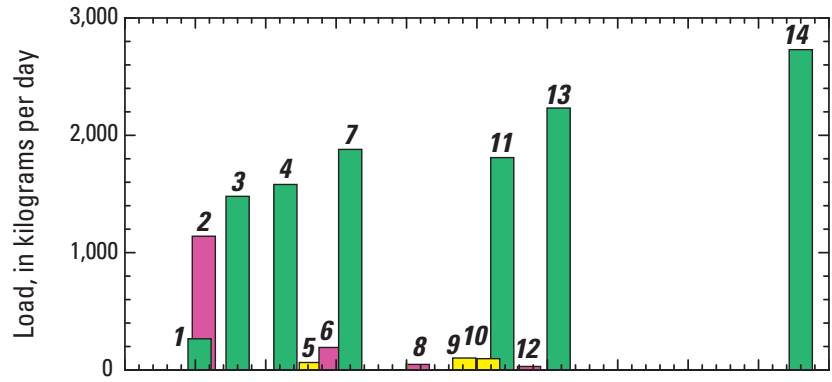

Total phosphorus

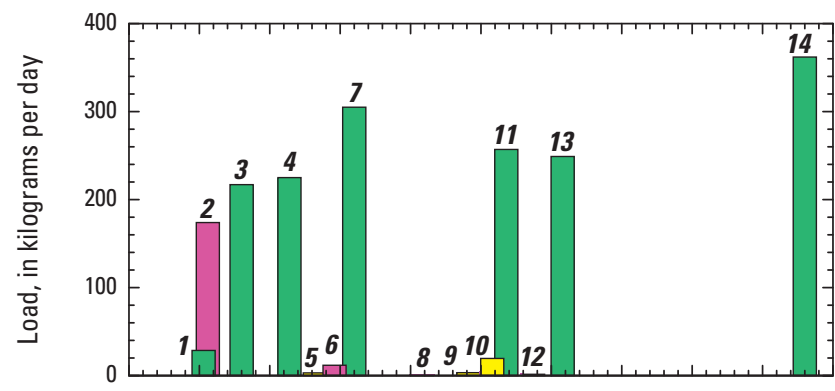

Suspended sediment

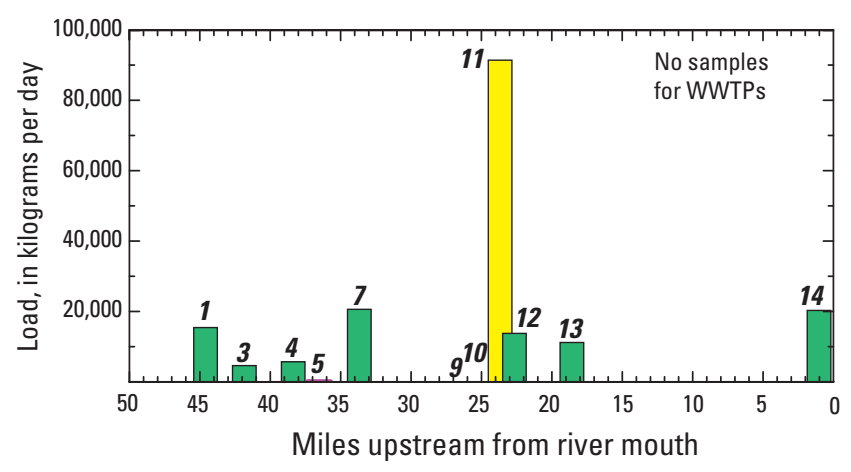

\section{EXPLANATION}

Monitoring station type

$\square$ Mainstem

Wastewater treatment plant (WWTP)

$\square$ Tributary

\section{Monitoring station name}

1 Blackstone River Millbury upstream (44.7 mi) 2 UBWPAD WWTP (44.4 mi)

3 Blackstone River Millbury downstream (42.0 mi)

4 Blackstone River Wilkinsonville (38.6 mi)

5 Quinsigamond River (36.8 mi)

6 Grafton WWTP (35.4 mi)

7 Blackstone River South Grafton (34.0 mi)

8 Northbridge WWTP (29.2 mi)

9 Mumford River (25.9 mi)

10 West River (24.2 mi)

11 Blackstone River Uxbridge (23.2 mi)

12 Uxbridge WWTP (21.3 mi)

13 Blackstone River Millville (19.2 mi)

14 Blackstone River Pawcatuck (2 mi)

$\boldsymbol{n} \boldsymbol{s}$ no samples
Streamflow at Blackstone River Millville station

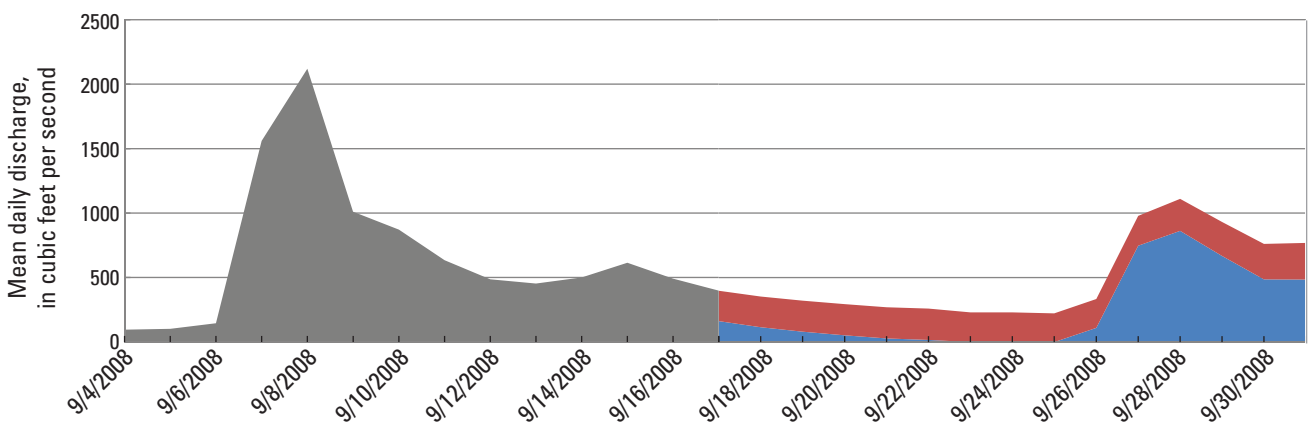

EXPLANATION

Flow component

Antecedent total flow

Sampling period runoff

Sampling period base flow

Figure 6-16. Constituent loads and streamflow at stream monitoring stations and wastewater treatment plants in the Blackstone River Basin, Massachusetts and Rhode Island, for the sampling period starting $P$, September 16, 2008. BFI, base-flow index (average during the sampling period); mi, miles; UBWPAD, Upper Blackstone Water Pollution Abatement District. 
Q. Sampling period starting April 27, 2009

Estimated Constituent Load

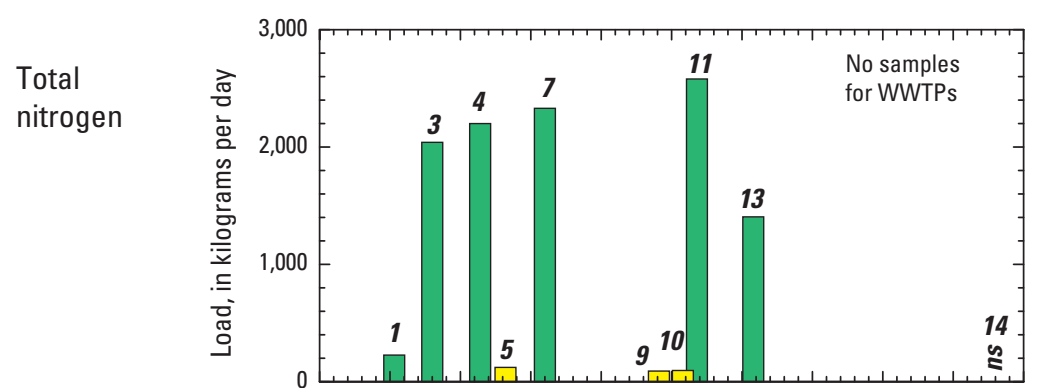

Total phosphorus
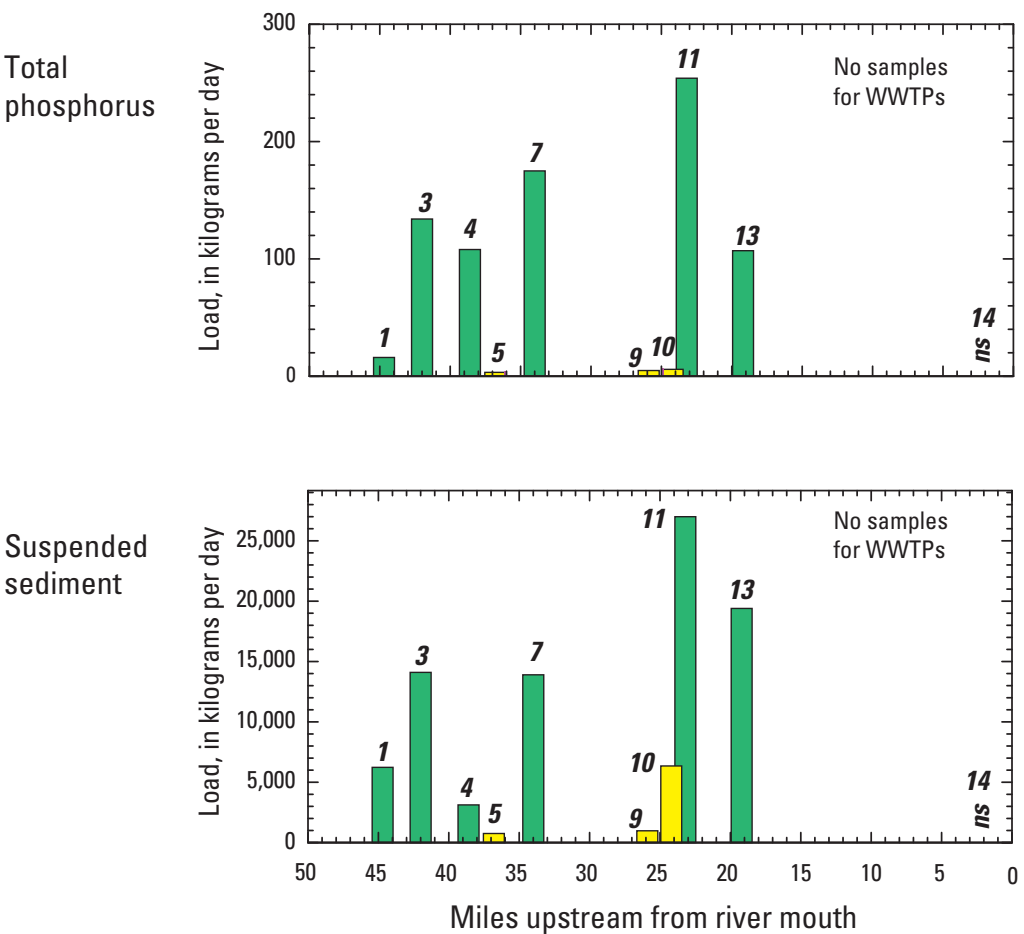

\section{EXPLANATION}

Monitoring station type

$\square$ Mainstem

Wastewater treatment plant (WWTP)

$\square$ Tributary

Monitoring station name

1 Blackstone River Millbury upstream (44.7 mi) 2 UBWPAD WWTP (44.4 mi)

3 Blackstone River Millbury downstream (42.0 mi)

4 Blackstone River Wilkinsonville (38.6 mi)

5 Quinsigamond River (36.8 mi)

6 Grafton WWTP (35.4 mi)

7 Blackstone River South Grafton (34.0 mi)

8 Northbridge WWTP (29.2 mi)

9 Mumford River (25.9 mi)

10 West River (24.2 mi)

11 Blackstone River Uxbridge (23.2 mi)

12 Uxbridge WWTP (21.3 mi)

13 Blackstone River Millville (19.2 mi)

14 Blackstone River Pawcatuck (2 mi)

$n \boldsymbol{s}$ no samples
Streamflow at Blackstone River Millville station

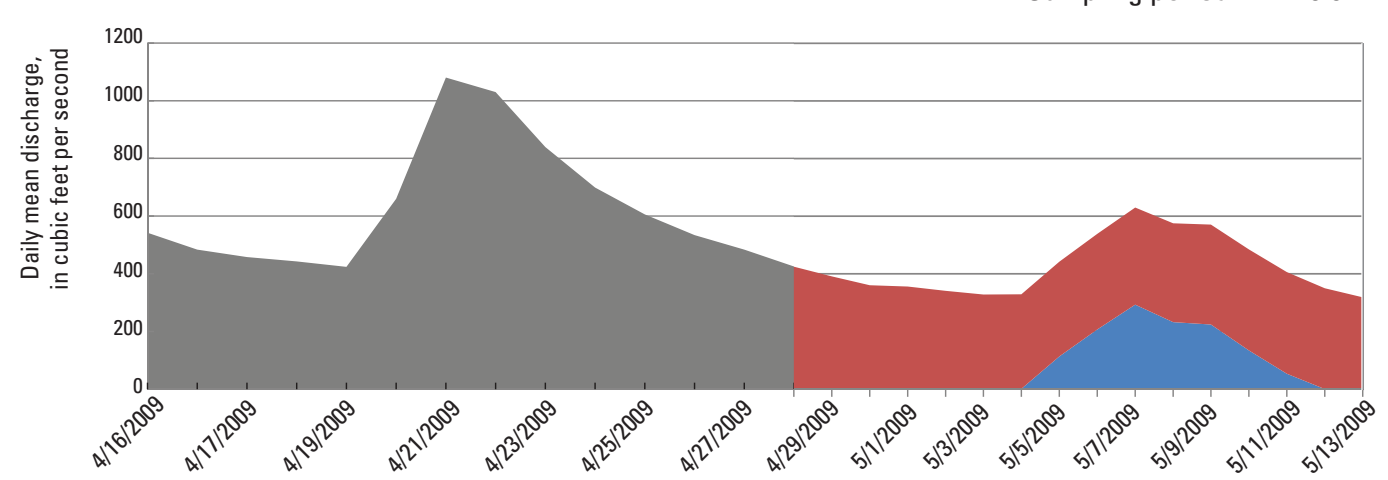

EXPLANATION

Flow component

Antecedent total flow

Sampling period runoff

Sampling period base flow

Figure 6-17. Constituent loads and streamflow at stream monitoring stations and wastewater treatment plants in the Blackstone River Basin, Massachusetts and Rhode Island, for the sampling period starting Q, April 27, 2009. BFl, base-flow index (average during the sampling period); mi, miles; UBWPAD, Upper Blackstone Water Pollution Abatement District. 
R. Sampling period starting May 13, 2009

Estimated Constituent Load

Total nitrogen

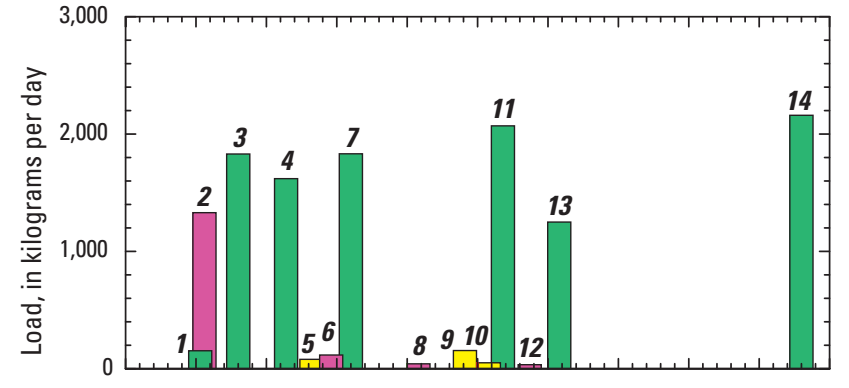

Total phosphorus
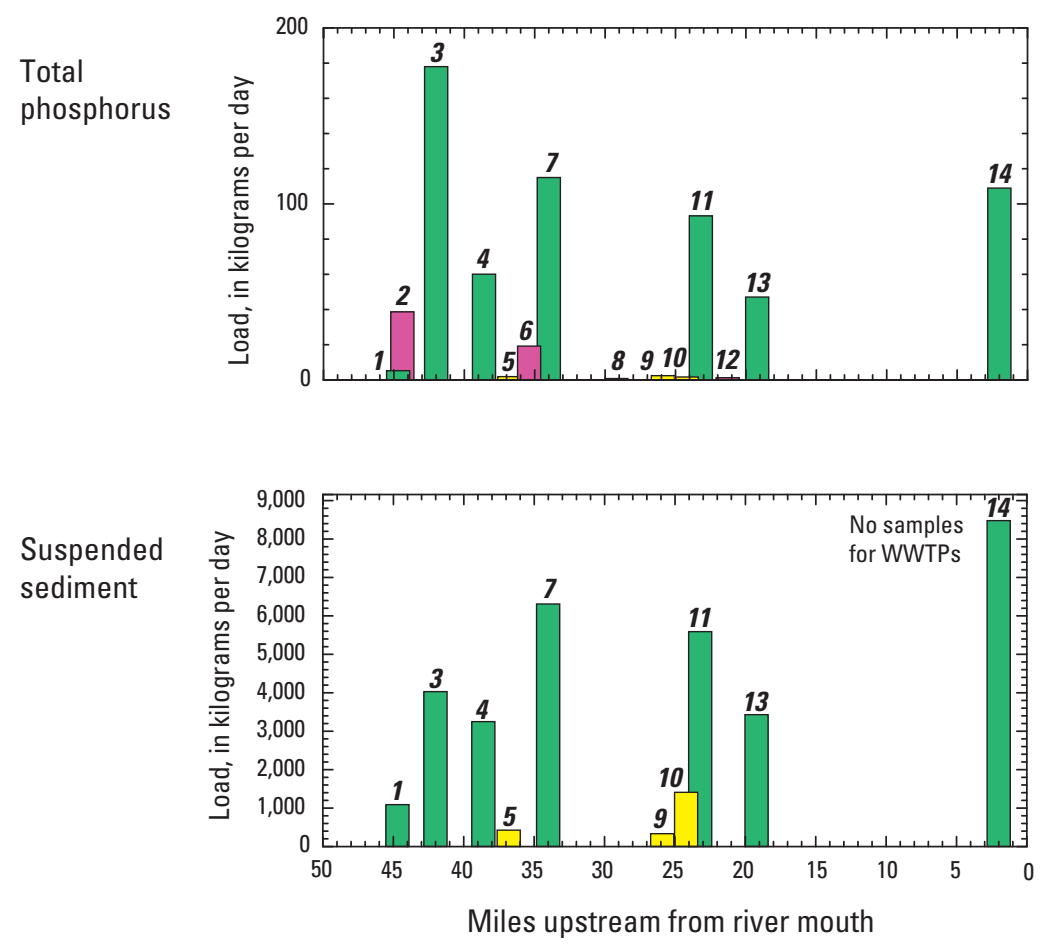

\section{EXPLANATION}

Monitoring station type

$\square$ Mainstem

$\square$ Wastewater treatment plant (WWTP)

$\square$ Tributary

\section{Monitoring station name}

1 Blackstone River Millbury upstream (44.7 mi) 2 UBWPAD WWTP (44.4 mi)

3 Blackstone River Millbury downstream (42.0 mi)

4 Blackstone River Wilkinsonville (38.6 mi)

5 Quinsigamond River (36.8 mi)

6 Grafton WWTP (35.4 mi)

7 Blackstone River South Grafton (34.0 mi)

8 Northbridge WWTP (29.2 mi)

9 Mumford River (25.9 mi)

10 West River (24.2 mi)

11 Blackstone River Uxbridge (23.2 mi)

12 Uxbridge WWTP (21.3 mi)

13 Blackstone River Millville (19.2 mi)

14 Blackstone River Pawcatuck (2 mi)

ns no samples
Streamflow at Blackstone River Millville station

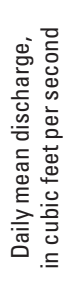

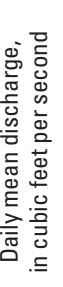

Sampling period $\mathrm{BFI}=0.98$

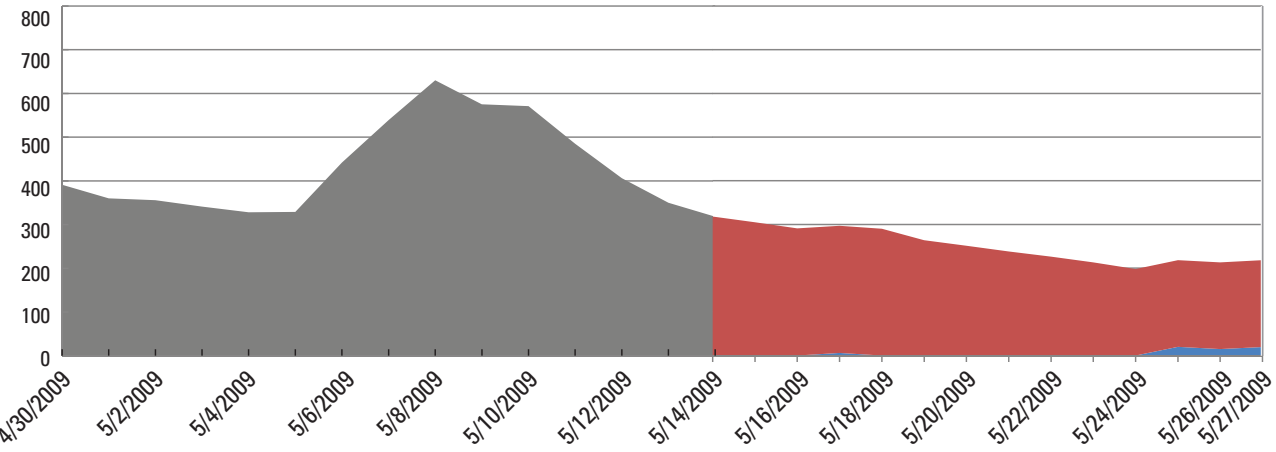

\section{EXPLANATION}

Flow component

Antecedent total flow

Sampling period runoff

Sampling period base flow

Figure 6-18. Constituent loads and streamflow at stream monitoring stations and wastewater treatment plants in the Blackstone River Basin, Massachusetts and Rhode Island, for the sampling period starting $R$, May 13, 2009. BFl, base-flow index (average during the sampling period); mi, miles; UBWPAD, Upper Blackstone Water Pollution Abatement District. 
S. Sampling period starting May 26, 2009

Estimated Constituent Load

Total nitrogen

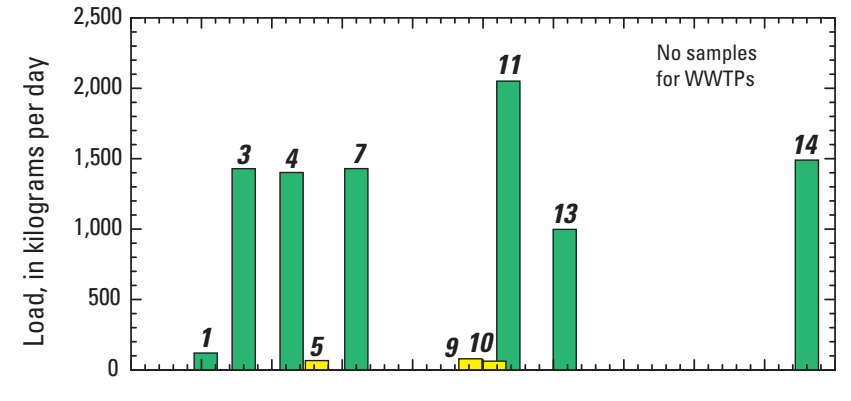

Total phosphorus

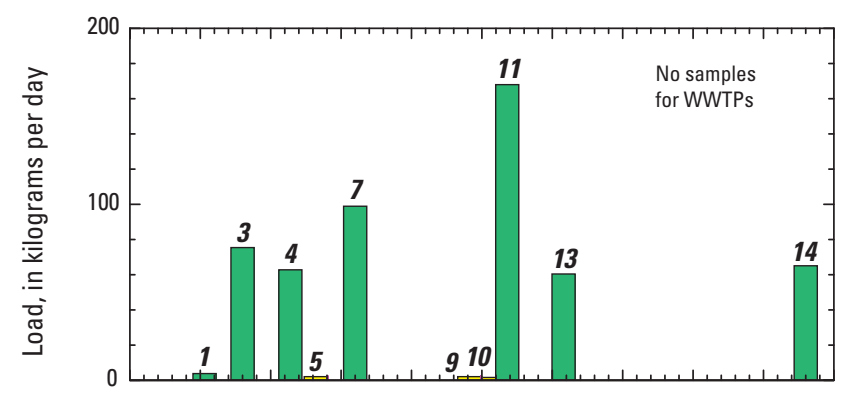

Suspended sediment

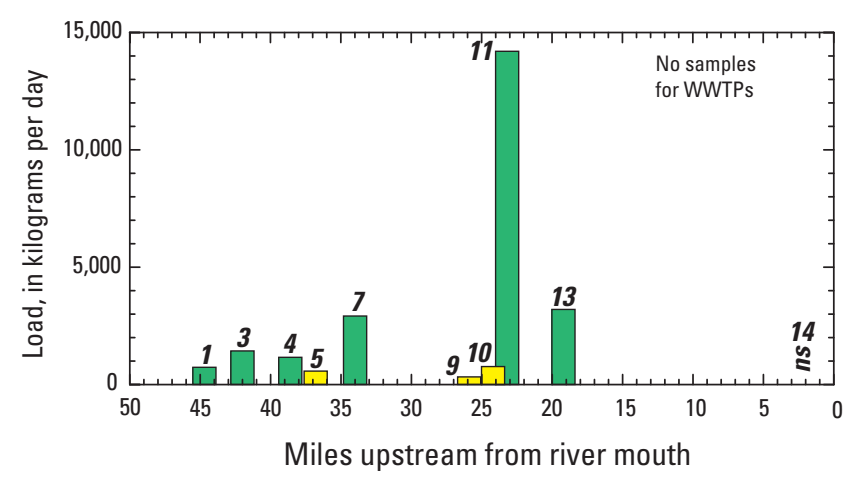

\section{EXPLANATION}

Monitoring station type

$\square$ Mainstem

Wastewater treatment plant (WWTP)

$\square$ Tributary

Monitoring station name

1 Blackstone River Millbury upstream (44.7 mi) 2 UBWPAD WWTP (44.4 mi)

3 Blackstone River Millbury downstream (42.0 mi)

4 Blackstone River Wilkinsonville (38.6 mi)

5 Quinsigamond River (36.8 mi)

6 Grafton WWTP (35.4 mi)

7 Blackstone River South Grafton (34.0 mi)

8 Northbridge WWTP (29.2 mi)

9 Mumford River (25.9 mi)

10 West River (24.2 mi)

11 Blackstone River Uxbridge (23.2 mi)

12 Uxbridge WWTP (21.3 mi)

13 Blackstone River Millville (19.2 mi)

14 Blackstone River Pawcatuck (2 mi)

$\boldsymbol{n} \boldsymbol{s}$ no samples

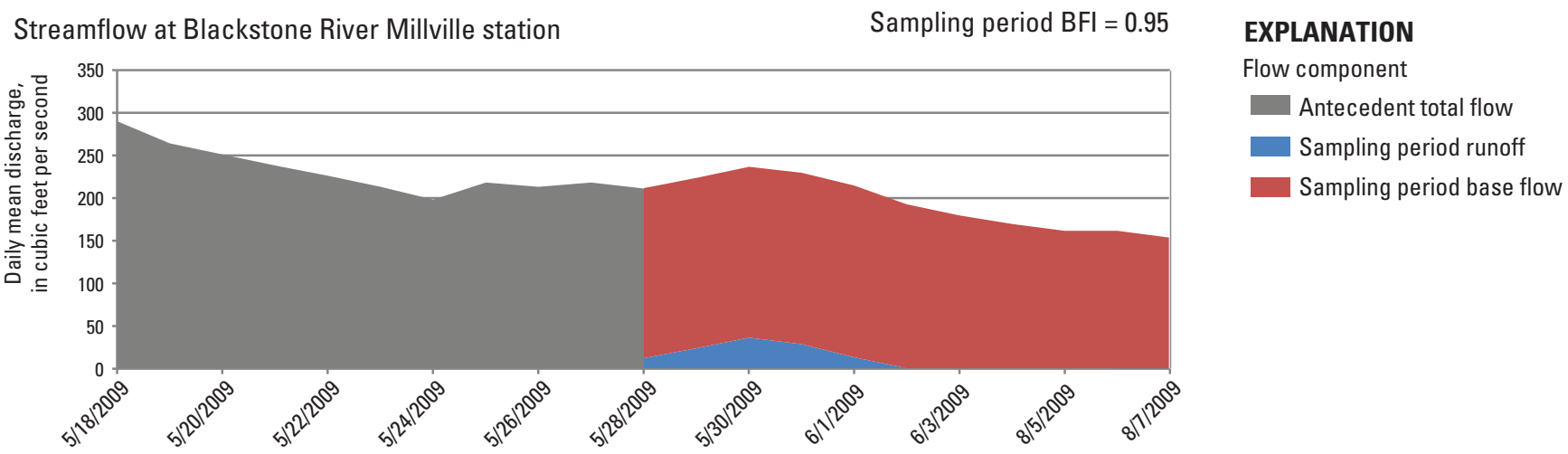

Figure 6-19. Constituent loads and streamflow at stream monitoring stations and wastewater treatment plants in the Blackstone River Basin, Massachusetts and Rhode Island, for the sampling period starting $S$, May 26, 2009. BFl, base-flow index (average during the sampling period); mi, miles; UBWPAD, Upper Blackstone Water Pollution Abatement District. 
T. Sampling period starting June 9, 2009

Estimated Constituent Load

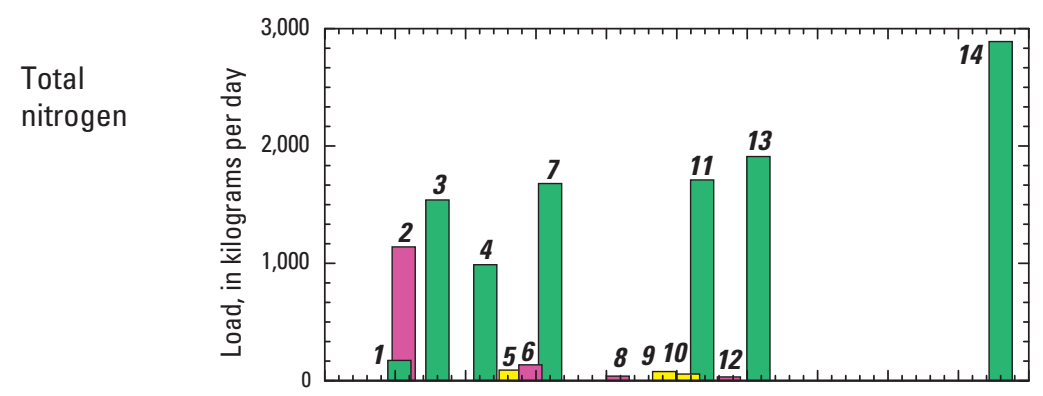

Total phosphorus

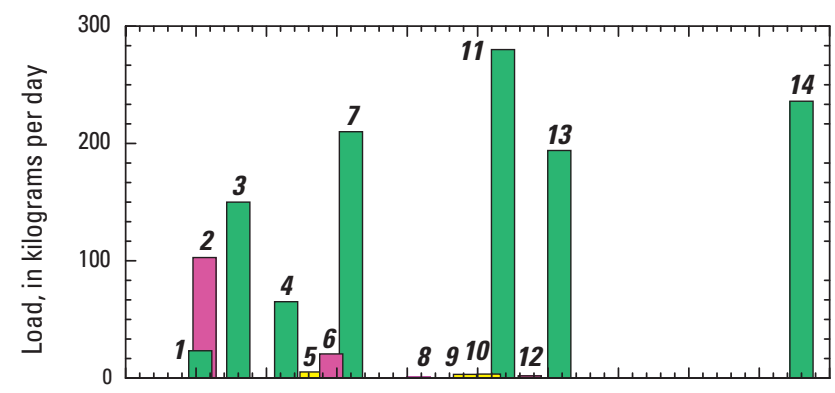

Suspended sediment

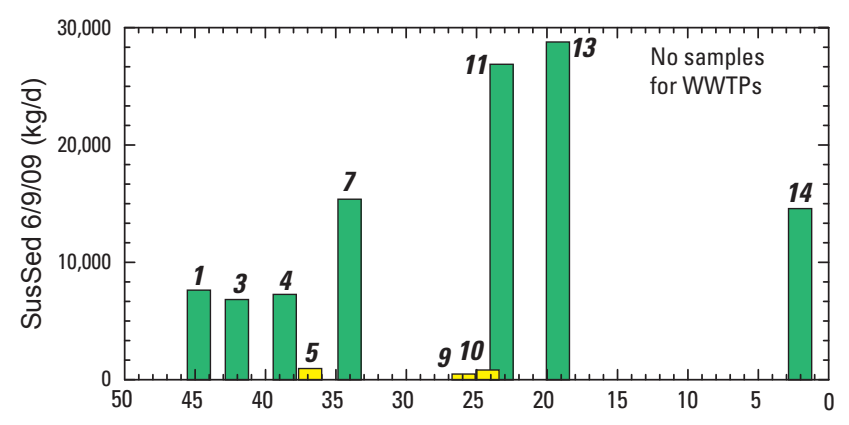

Miles upstream from river mouth

\section{EXPLANATION}

\section{Monitoring station type}

$\square$ Mainstem

Wastewater treatment plant (WWTP)

Tributary

\section{Monitoring station name}

1 Blackstone River Millbury upstream (44.7 mi) 2 UBWPAD WWTP (44.4 mi)

3 Blackstone River Millbury downstream (42.0 mi)

4 Blackstone River Wilkinsonville (38.6 mi)

5 Quinsigamond River (36.8 mi)

6 Grafton WWTP (35.4 mi)

7 Blackstone River South Grafton (34.0 mi)

8 Northbridge WWTP (29.2 mi)

9 Mumford River (25.9 mi)

10 West River (24.2 mi)

11 Blackstone River Uxbridge (23.2 mi)

12 Uxbridge WWTP (21.3 mi)

13 Blackstone River Millville (19.2 mi)

14 Blackstone River Pawcatuck (2 mi)

ns no samples
Streamflow at Blackstone River Millville station

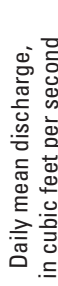

Sampling period $\mathrm{BFI}=0.45$

Flow component

Antecedent total flow

Sampling period runoff

Sampling period base flow

Figure 6-20. Constituent loads and streamflow at stream monitoring stations and wastewater treatment plants in the Blackstone River Basin, Massachusetts and Rhode Island, for the sampling period starting T, June 9, 2009. BFI, base-flow index (average during the sampling period); mi, miles; UBWPAD, Upper Blackstone Water Pollution Abatement District. 
$\boldsymbol{U}$. Sampling period starting June 23, 2009

Estimated Constituent Load

Total nitrogen

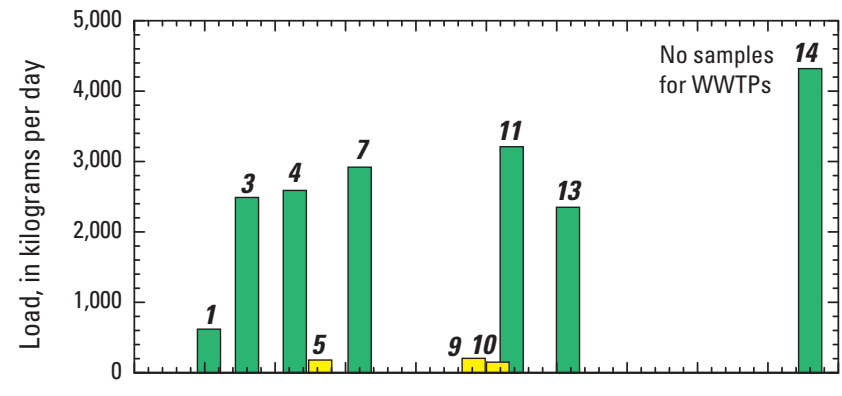

Total phosphorus
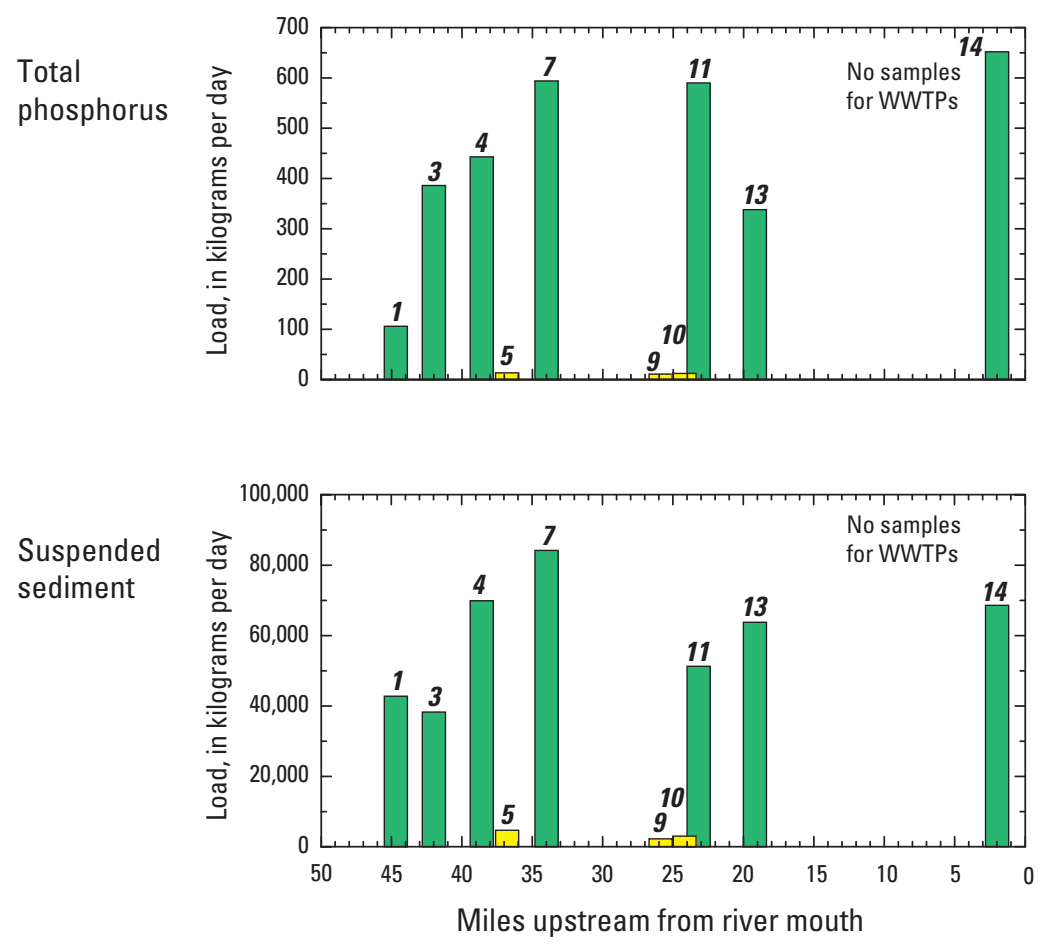

\section{EXPLANATION}

Monitoring station type

$\square$ Mainstem

Wastewater treatment plant (WWTP)

Tributary

\section{Monitoring station name}

1 Blackstone River Millbury upstream (44.7 mi) 2 UBWPAD WWTP (44.4 mi)

3 Blackstone River Millbury downstream (42.0 mi)

4 Blackstone River Wilkinsonville (38.6 mi)

5 Quinsigamond River (36.8 mi)

6 Grafton WWTP (35.4 mi)

7 Blackstone River South Grafton (34.0 mi)

8 Northbridge WWTP (29.2 mi)

9 Mumford River (25.9 mi)

10 West River (24.2 mi)

11 Blackstone River Uxbridge (23.2 mi)

12 Uxbridge WWTP (21.3 mi)

13 Blackstone River Millville (19.2 mi)

14 Blackstone River Pawcatuck (2 mi)

$n s$ no samples
Streamflow at Blackstone River Millville station

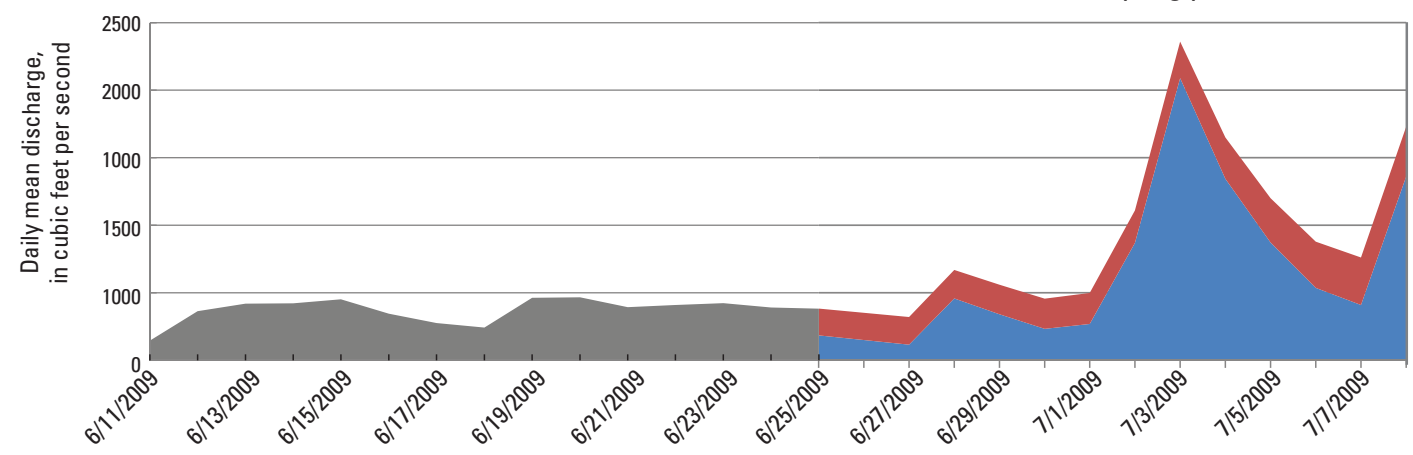

\section{EXPLANATION}

Flow component

Antecedent total flow

Sampling period runoff

Sampling period base flow

Figure 6-21. Constituent loads and streamflow at stream monitoring stations and wastewater treatment plants in the Blackstone River Basin, Massachusetts and Rhode Island, for the sampling period starting U, June 23, 2009. BFI, base-flow index (average during the sampling period); mi, miles; UBWPAD, Upper Blackstone Water Pollution Abatement District. 
V. Sampling period starting July 7, 2009

Estimated Constituent Load

Total nitrogen

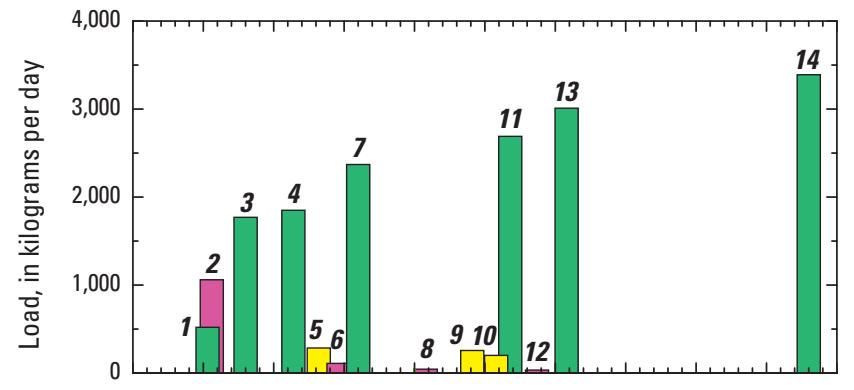

Total phosphorus

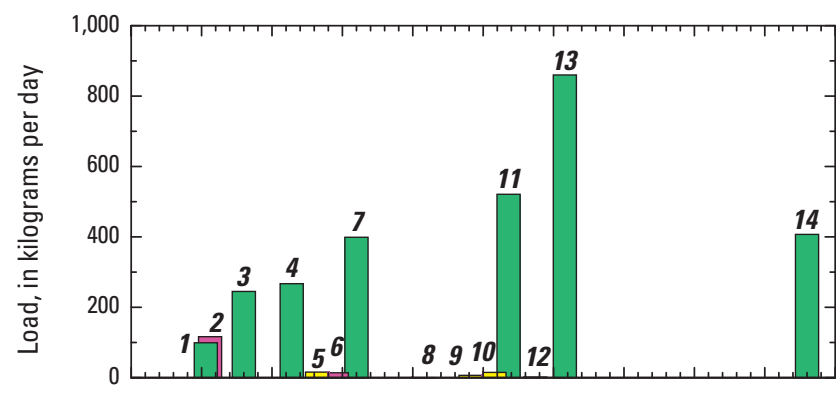

Suspended sediment

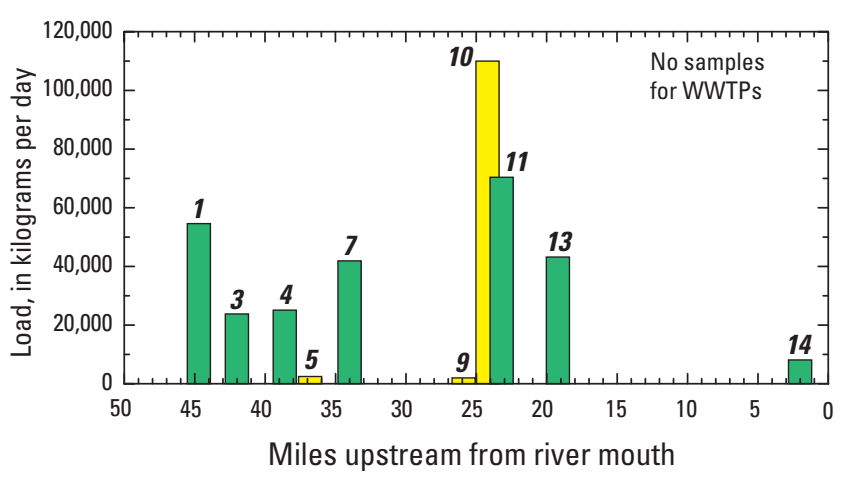

\section{EXPLANATION}

Monitoring station type

$\square$ Mainstem

Wastewater treatment plant (WWTP)

$\square$ Tributary

\section{Monitoring station name}

1 Blackstone River Millbury upstream (44.7 mi) 2 UBWPAD WWTP (44.4 mi)

3 Blackstone River Millbury downstream (42.0 mi)

4 Blackstone River Wilkinsonville (38.6 mi)

5 Quinsigamond River (36.8 mi)

6 Grafton WWTP (35.4 mi)

7 Blackstone River South Grafton (34.0 mi)

8 Northbridge WWTP (29.2 mi)

9 Mumford River (25.9 mi)

10 West River (24.2 mi)

11 Blackstone River Uxbridge (23.2 mi)

12 Uxbridge WWTP (21.3 mi)

13 Blackstone River Millville (19.2 mi)

14 Blackstone River Pawcatuck (2 mi)

ns no samples
Streamflow at Blackstone River Millville station

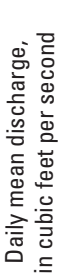

$\begin{array}{ll} & \\ & \\ & \\ & \\ & \\ & \end{array}$
Sampling period $\mathrm{BFI}=0.58$

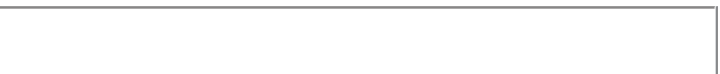

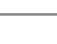

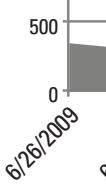

Figure 6-22. Constituent loads and streamflow at stream monitoring stations and wastewater treatment plants in the Blackstone River Basin, Massachusetts and Rhode Island, for the sampling period starting $V$, July 7, 2009. BFl, base-flow index (average during the sampling period); mi, miles; UBWPAD, Upper Blackstone Water Pollution Abatement District.

\section{EXPLANATION}

Flow component

Antecedent total flow

Sampling period runoff

Sampling period base flow 
W. Sampling period starting July 21, 2009

Estimated Constituent Load

Total nitrogen

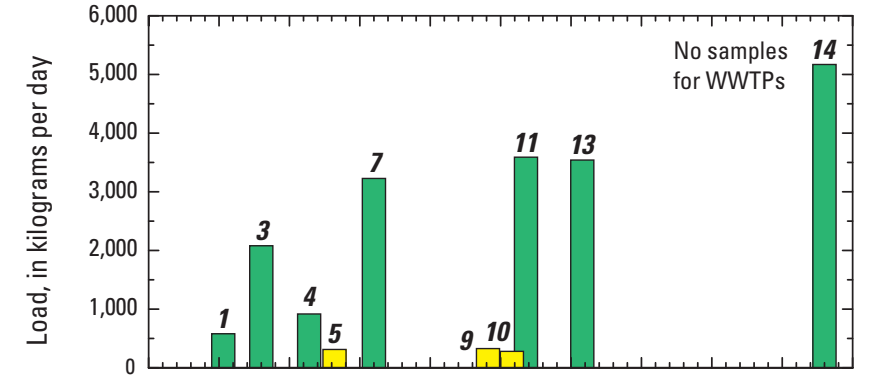

Total phosphorus
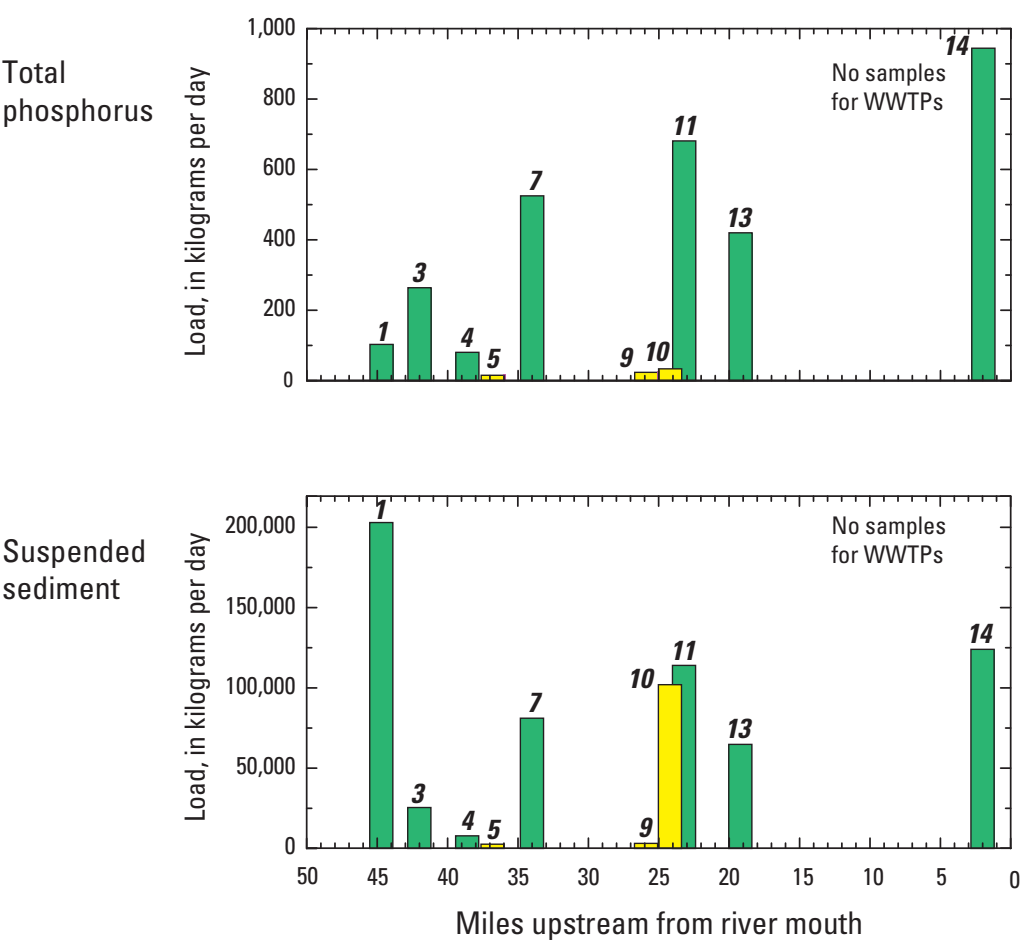

\section{EXPLANATION}

Monitoring station type

$\square$ Mainstem

$\square$ Wastewater treatment plant (WWTP)

$\square$ Tributary

Monitoring station name

1 Blackstone River Millbury upstream (44.7 mi)

2 UBWPAD WWTP (44.4 mi)

3 Blackstone River Millbury downstream (42.0 mi)

4 Blackstone River Wilkinsonville (38.6 mi)

5 Quinsigamond River (36.8 mi)

6 Grafton WWTP (35.4 mi)

7 Blackstone River South Grafton (34.0 mi)

8 Northbridge WWTP (29.2 mi)

9 Mumford River (25.9 mi)

10 West River (24.2 mi)

11 Blackstone River Uxbridge (23.2 mi)

12 Uxbridge WWTP (21.3 mi)

13 Blackstone River Millville (19.2 mi)

14 Blackstone River Pawcatuck (2 mi)

ns no samples
Streamflow at Blackstone River Millville station

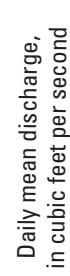

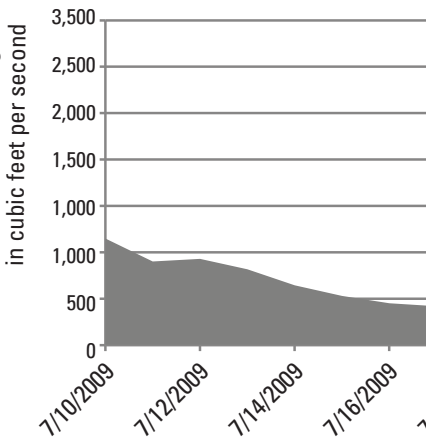

Sampling period $\mathrm{BFI}=0.41$

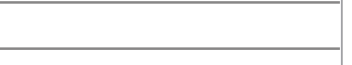

$+2$
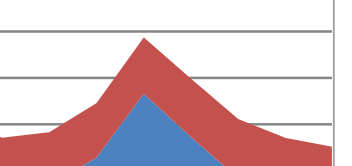

\section{EXPLANATION}

Flow component

Antecedent total flow

Sampling period runoff

Sampling period base flow

Figure 6-23. Constituent loads and streamflow at stream monitoring stations and wastewater treatment plants in the Blackstone River Basin, Massachusetts and Rhode Island, for the sampling period starting W, July 21, 2009. BFl, base-flow index (average during the sampling period); mi, miles; UBWPAD, Upper Blackstone Water Pollution Abatement District. 
X. Sampling period starting August 4, 2009

Estimated Constituent Load

Total nitrogen

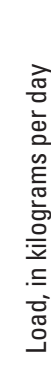

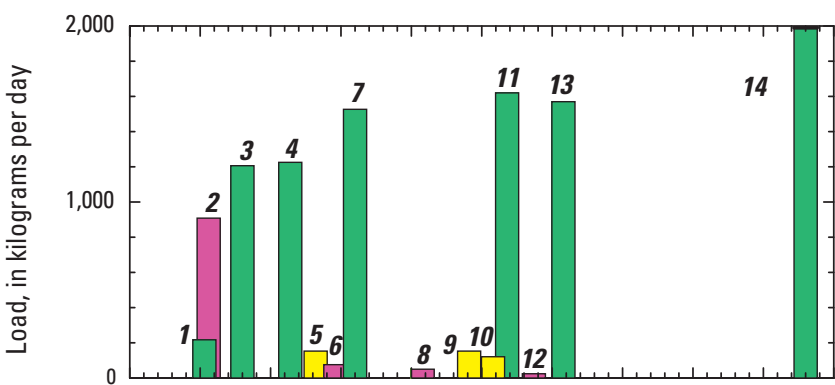

Total phosphorus
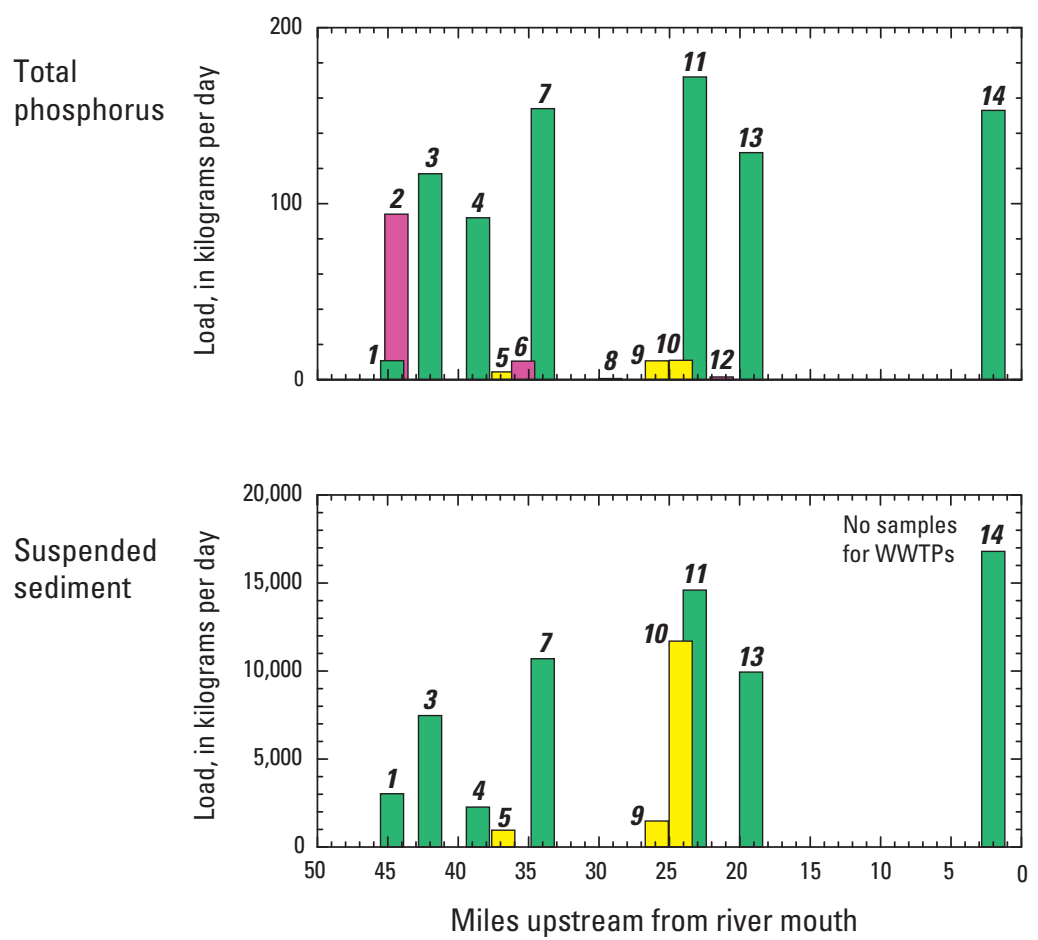

\section{EXPLANATION}

\section{Monitoring station type}

$\square$ Mainstem

Wastewater treatment plant (WWTP)

$\square$ Tributary

\section{Monitoring station name}

1 Blackstone River Millbury upstream (44.7 mi) 2 UBWPAD WWTP (44.4 mi)

3 Blackstone River Millbury downstream (42.0 mi)

4 Blackstone River Wilkinsonville (38.6 mi)

5 Quinsigamond River (36.8 mi)

6 Grafton WWTP (35.4 mi)

7 Blackstone River South Grafton (34.0 mi)

8 Northbridge WWTP (29.2 mi)

9 Mumford River (25.9 mi)

10 West River (24.2 mi)

11 Blackstone River Uxbridge (23.2 mi)

12 Uxbridge WWTP (21.3 mi)

13 Blackstone River Millville (19.2 mi)

14 Blackstone River Pawcatuck (2 mi)

ns no samples
Streamflow at Blackstone River Millville station

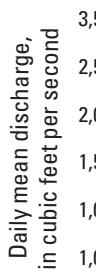

Sampling period $\mathrm{BFI}=0.99$

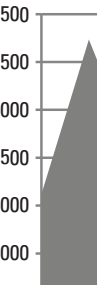

500.

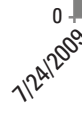

Figure 6-24. Constituent loads and streamflow at stream monitoring stations and wastewater treatment plants in the Blackstone River Basin, Massachusetts and Rhode Island, for the sampling period starting $X$, August 4, 2009. BFI, base-flow index (average during the sampling period); mi, miles; UBWPAD, Upper Blackstone Water Pollution Abatement District. 
Y. Sampling period starting August 18, 2009

Estimated Constituent Load

Total nitrogen

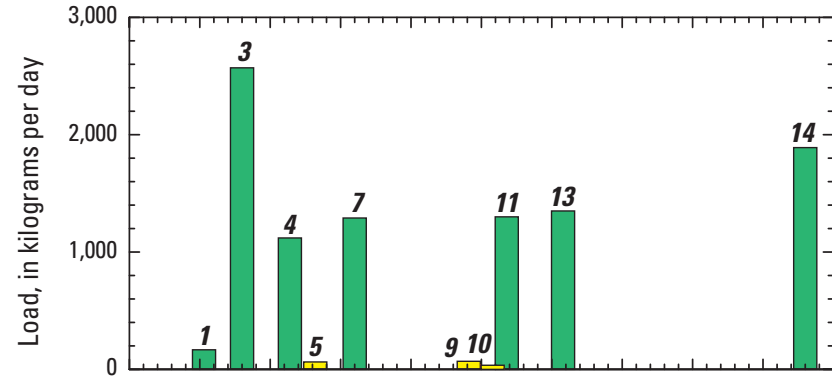

Total phosphorus

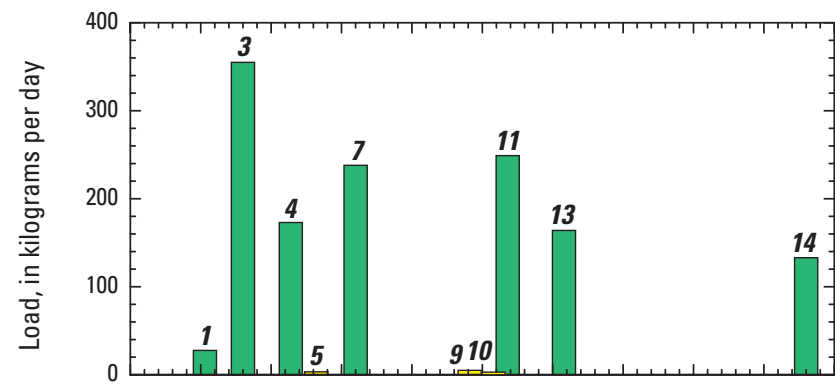

Suspended sediment

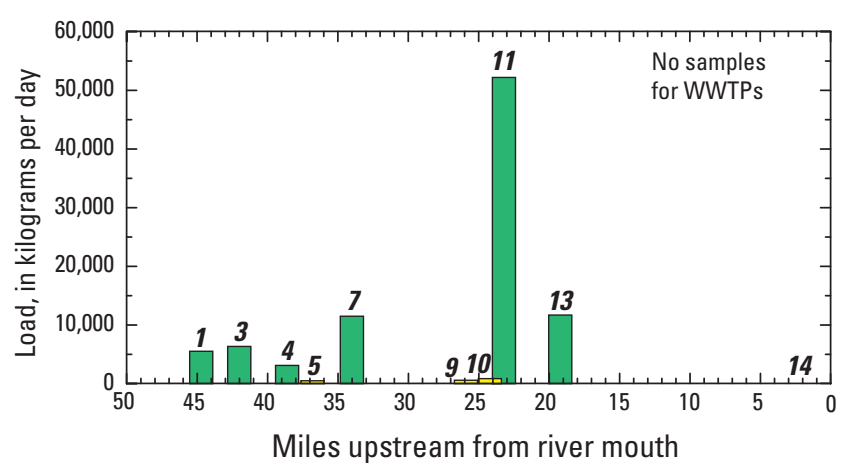

\section{EXPLANATION}

Monitoring station type

$\square$ Mainstem

$\square$ Wastewater treatment plant (WWTP)

Tributary

\section{Monitoring station name}

1 Blackstone River Millbury upstream (44.7 mi) 2 UBWPAD WWTP (44.4 mi)

3 Blackstone River Millbury downstream (42.0 mi)

4 Blackstone River Wilkinsonville (38.6 mi)

5 Quinsigamond River (36.8 mi)

6 Grafton WWTP (35.4 mi)

7 Blackstone River South Grafton (34.0 mi)

8 Northbridge WWTP (29.2 mi)

9 Mumford River (25.9 mi)

10 West River (24.2 mi)

11 Blackstone River Uxbridge $(23.2 \mathrm{mi})$

12 Uxbridge WWTP (21.3 mi)

13 Blackstone River Millville (19.2 mi)

14 Blackstone River Pawcatuck (2 mi)

ns no samples

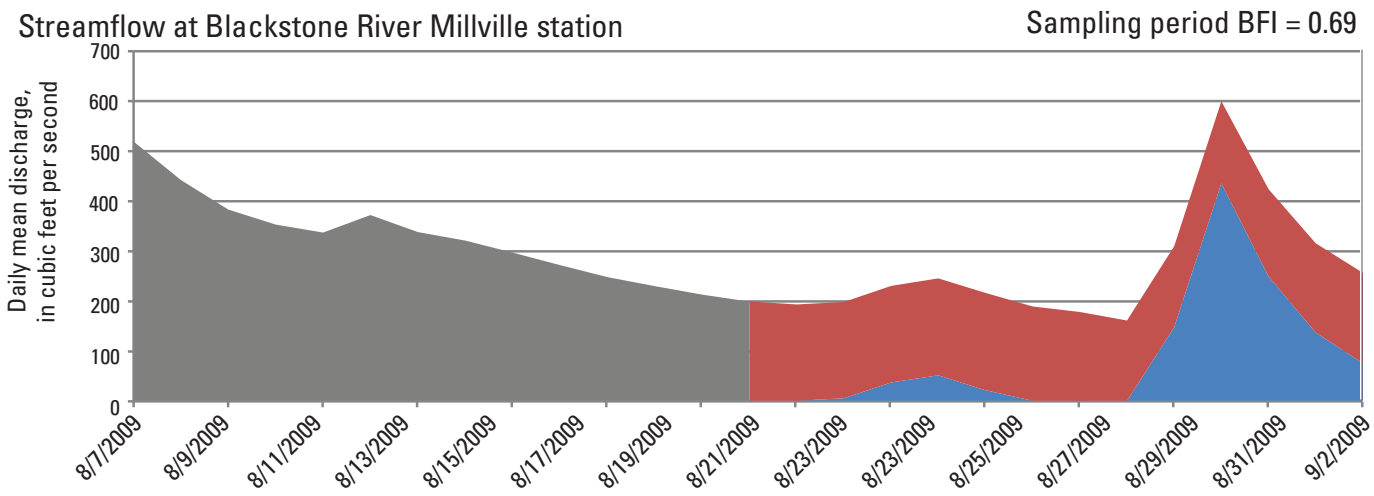

\section{EXPLANATION}

Flow component

Antecedent total flow

Sampling period runoff

Sampling period base flow

Figure 6-25. Constituent loads and streamflow at stream monitoring stations and wastewater treatment plants in the Blackstone River Basin, Massachusetts and Rhode Island, for the sampling period starting Y, August 18, 2009. BFI, base-flow index (average during the sampling period); mi, miles; UBWPAD, Upper Blackstone Water Pollution Abatement District. 
Z. Sampling period starting September 1, 2009

Estimated Constituent Load

Total nitrogen

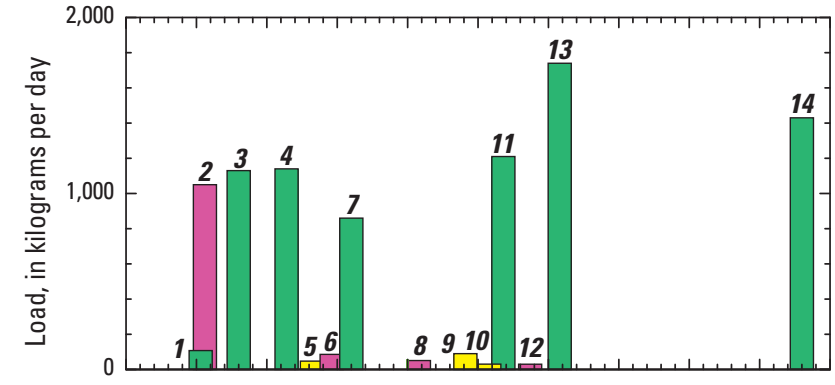

Total phosphorus

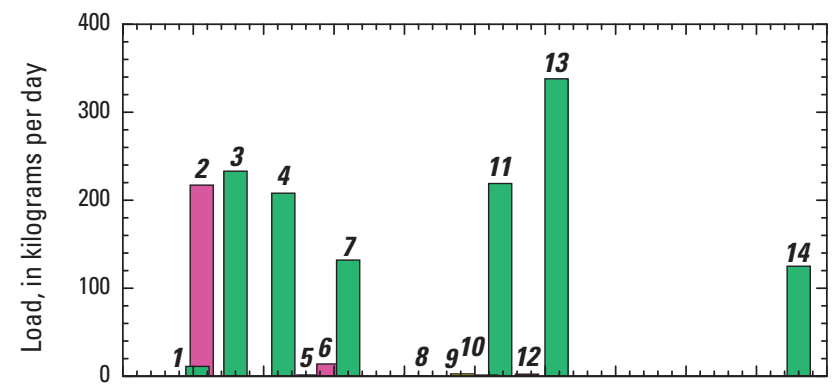

Suspended sediment

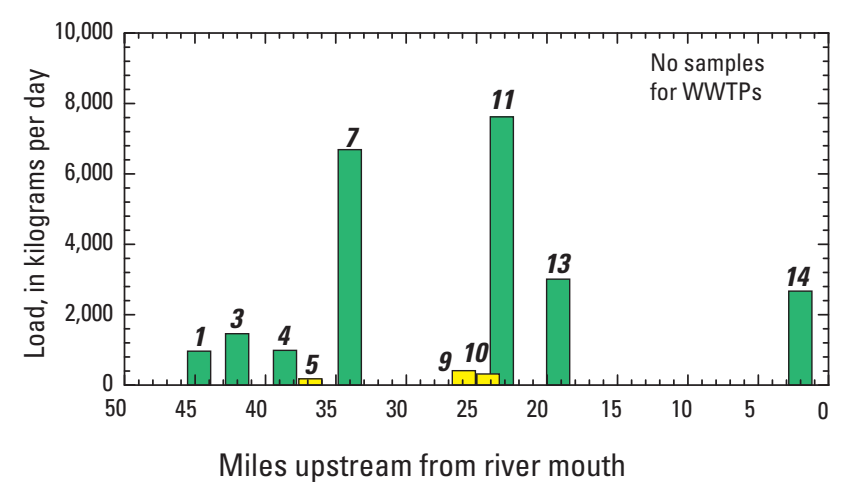

\section{EXPLANATION}

Monitoring station type

$\square$ Mainstem

Wastewater treatment plant (WWTP)

$\square$ Tributary

\section{Monitoring station name}

1 Blackstone River Millbury upstream (44.7 mi) 2 UBWPAD WWTP (44.4 mi)

3 Blackstone River Millbury downstream (42.0 mi)

4 Blackstone River Wilkinsonville (38.6 mi)

5 Quinsigamond River (36.8 mi)

6 Grafton WWTP (35.4 mi)

7 Blackstone River South Grafton (34.0 mi)

8 Northbridge WWTP $(29.2 \mathrm{mi})$

9 Mumford River (25.9 mi)

10 West River (24.2 mi)

11 Blackstone River Uxbridge $(23.2 \mathrm{mi})$

12 Uxbridge WWTP (21.3 mi)

13 Blackstone River Millville (19.2 mi)

14 Blackstone River Pawcatuck (2 mi)

ns no samples
Streamflow at Blackstone River Millville station

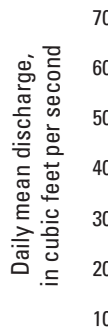

$$
\begin{aligned}
& 700 \\
& 600 \\
& 500 \\
& 400 \\
& 300 \\
& 200 \\
& 100 \\
& 0
\end{aligned}
$$<smiles>[CH]=[Co]</smiles>

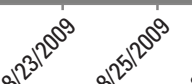

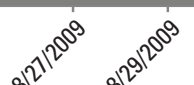<smiles>[C+]=[Co]</smiles><smiles>[CH]=[Co]</smiles><smiles>C1CCCCCCCCCCCC1</smiles><smiles>[CH][CH]</smiles><smiles>C1CC2C3CC1CC2C3</smiles>

Sampling period $\mathrm{BFI}=0.79$

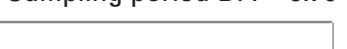

Figure 6-26. Constituent loads and streamflow at stream monitoring stations and wastewater treatment plants in the Blackstone River Basin, Massachusetts and Rhode Island, for the sampling period starting Z, September 1, 2009. BFI, base-flow index (average during the sampling period); mi, miles; UBWPAD, Upper Blackstone Water Pollution Abatement District.

\section{EXPLANATION}

Flow component

Antecedent total flow

Sampling period runoff

Sampling period base flow 
$\boldsymbol{A A}$. Sampling period starting September 15, 2009

Estimated Constituent Load

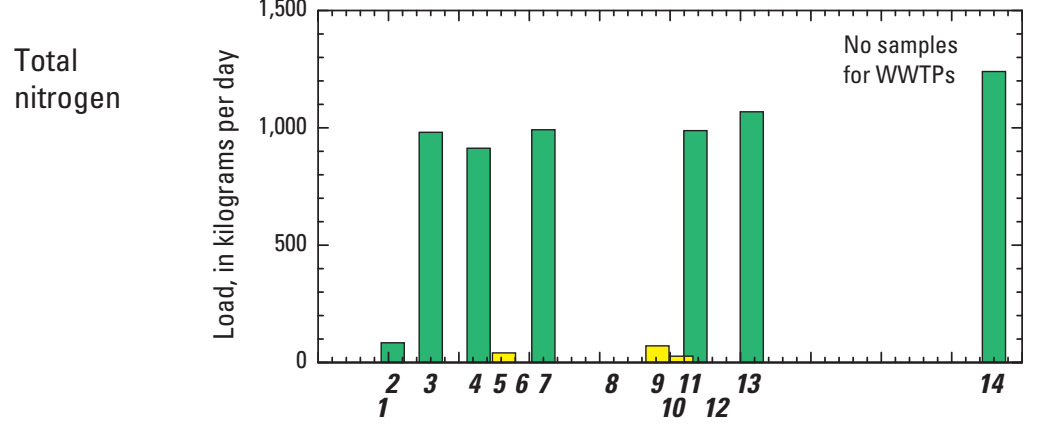

Total phosphorus
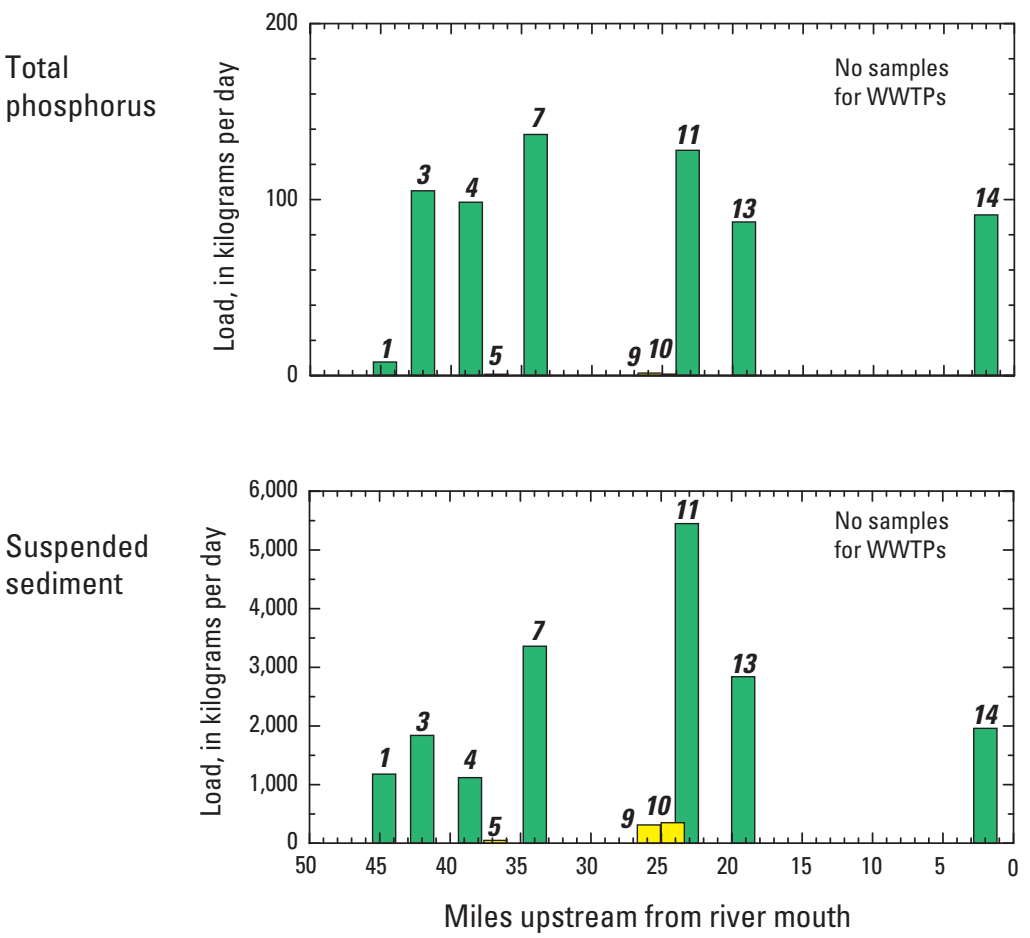

\section{EXPLANATION}

Monitoring station type

$\square$ Mainstem

Wastewater treatment plant (WWTP)

$\square$ Tributary

\section{Monitoring station name}

1 Blackstone River Millbury upstream (44.7 mi) 2 UBWPAD WWTP (44.4 mi)

3 Blackstone River Millbury downstream (42.0 mi)

4 Blackstone River Wilkinsonville (38.6 mi)

5 Quinsigamond River (36.8 mi)

6 Grafton WWTP (35.4 mi)

7 Blackstone River South Grafton (34.0 mi)

8 Northbridge WWTP (29.2 mi)

9 Mumford River (25.9 mi)

10 West River (24.2 mi)

11 Blackstone River Uxbridge (23.2 mi)

12 Uxbridge WWTP (21.3 mi)

13 Blackstone River Millville (19.2 mi)

14 Blackstone River Pawcatuck (2 mi)

ns no samples
Streamflow at Blackstone River Millville station

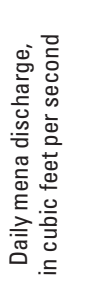

Sampling period $\mathrm{BFI}=0.81$
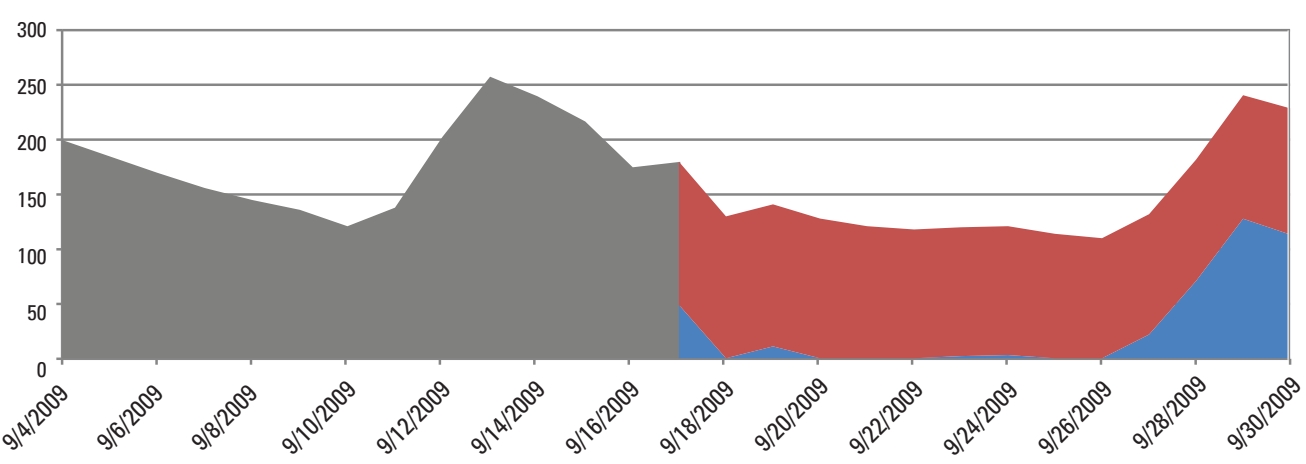

\section{EXPLANATION}

Flow component

Antecedent total flow

Sampling period runoff

Sampling period base flow

Figure 6-27. Constituent loads and streamflow at stream monitoring stations and wastewater treatment plants in the Blackstone River Basin, Massachusetts and Rhode Island, for the sampling period starting AA, September 15, 2009. BFI, base-flow index (average during the sampling period); mi, miles; UBWPAD, Upper Blackstone Water Pollution Abatement District. 
Prepared by the Pembroke Publishing Service Center. For more information concerning this report, contact:

\section{Office Chief}

Massachusetts-Rhode Island Office

New England Water Science Center

U.S. Geological Survey

10 Bearfoot Road

Northborough, MA 01532

dc_ma@usgs.gov

or visit our Web site at: http://ma.water.usgs.gov 
